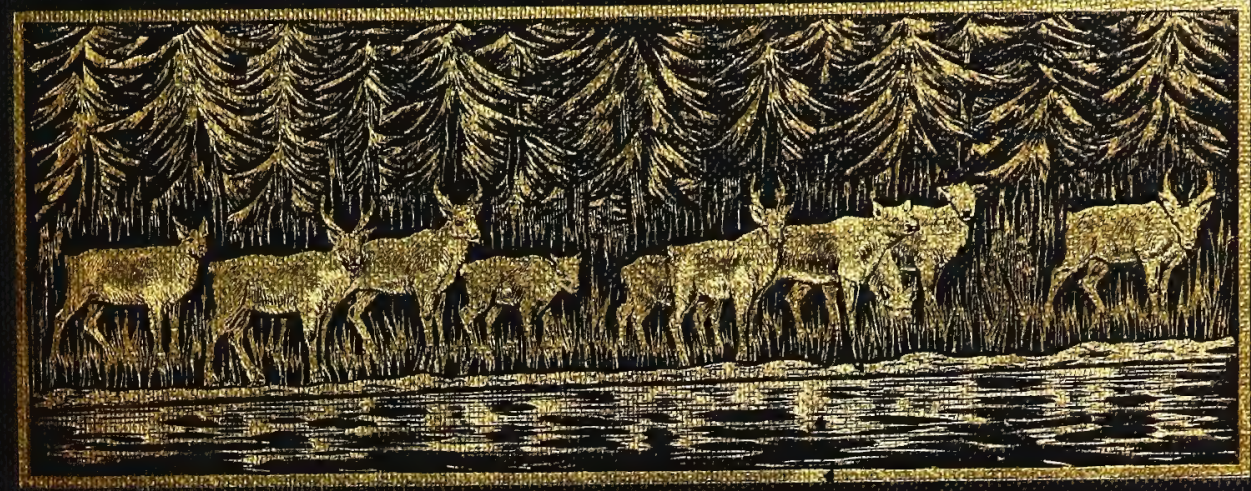

\title{
WILD LIFE AND THE CAMERA
}

\section{A.RADCLYFFE DUGMORE}




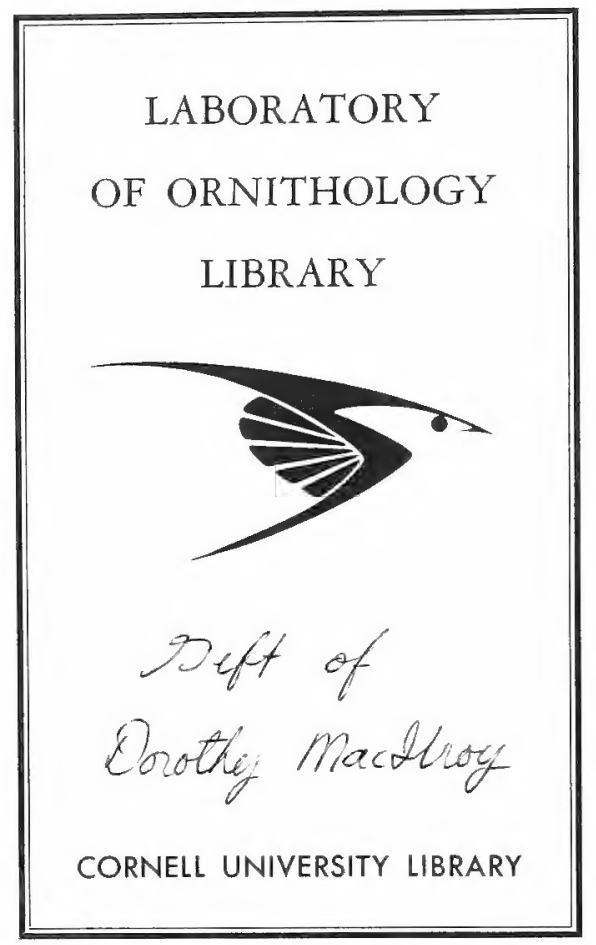


Cornell University Library

QH 245.D86

Wild life and the camera,

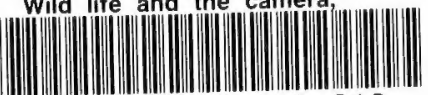

$31924022 \quad 516 \quad 318$
Laboratory of Ornithology

159 Sapsucker Woods Road

Cornell University

Jthaca, New York 14850

All books are subject to recall after two weeks

DATE DUE

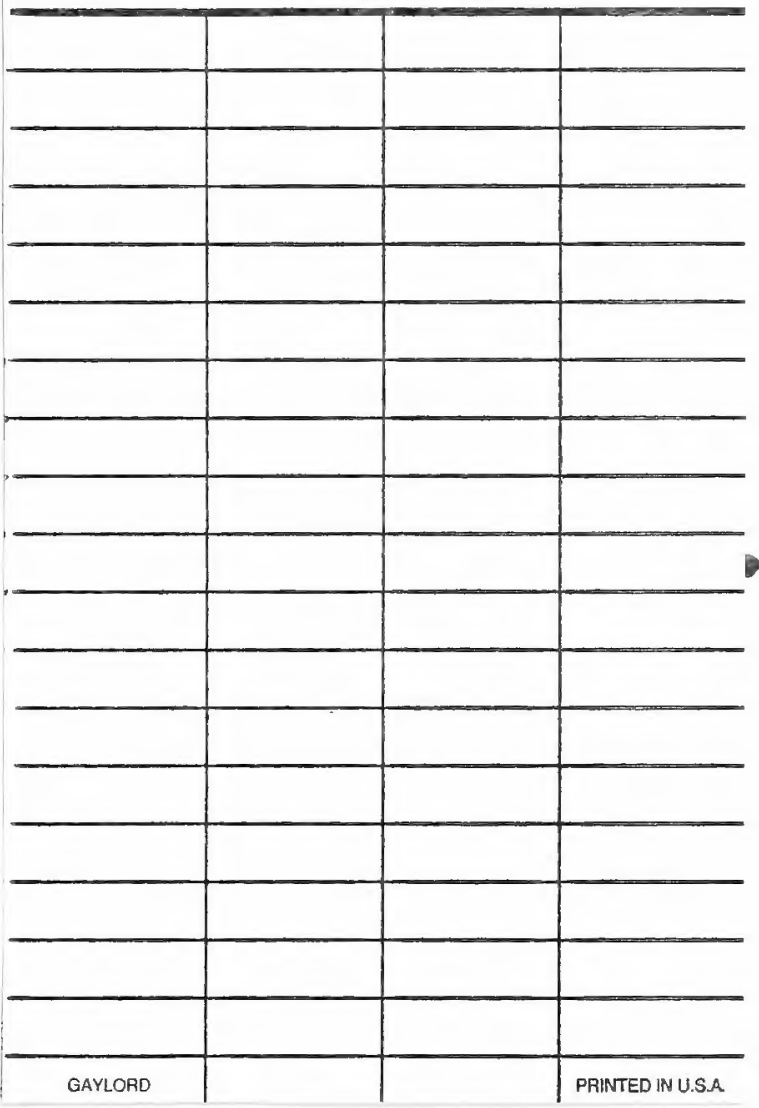





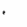



WILD LIFE AND THE CAMERA 

. 


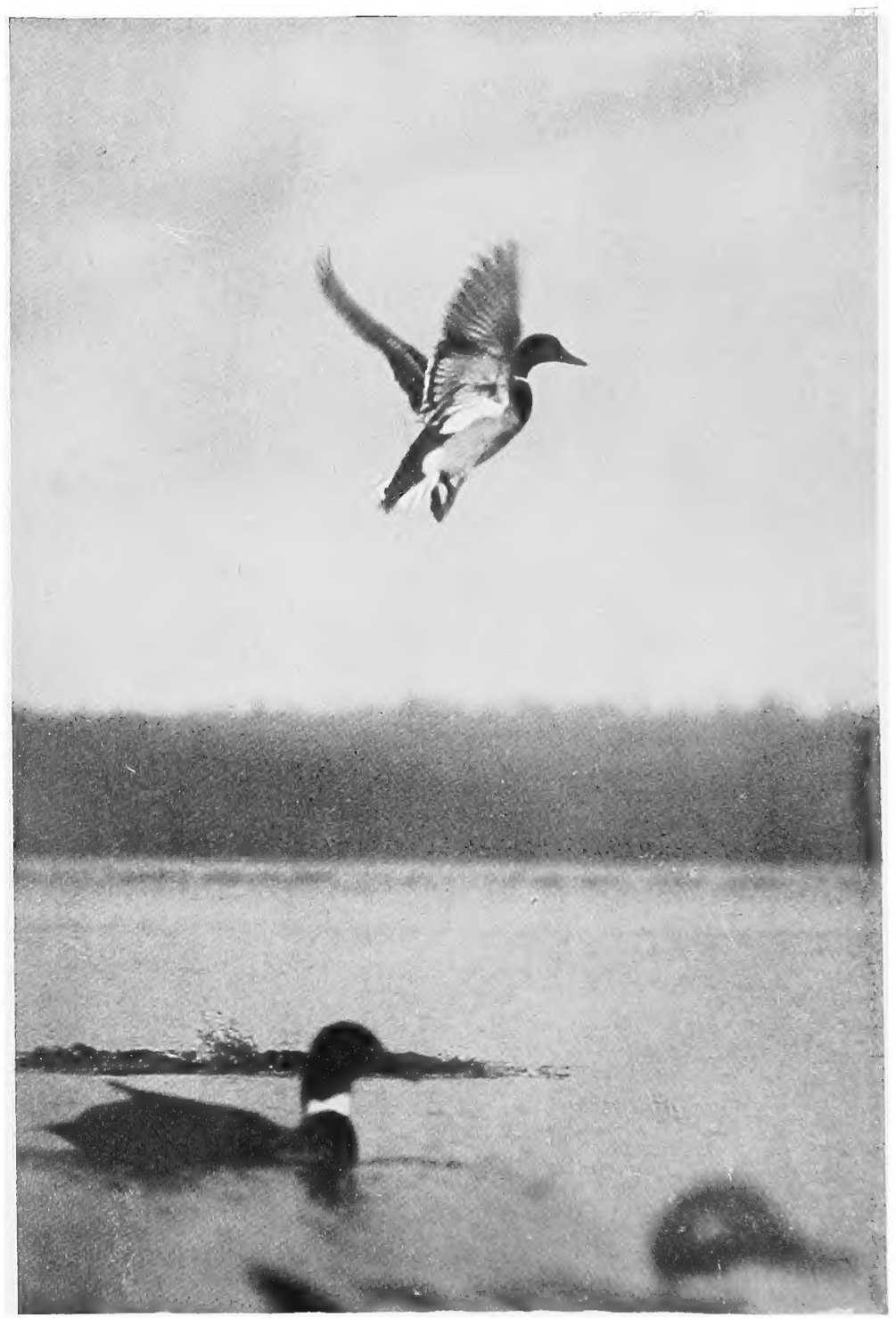

Widd-Mallard rising. The speed with which thow bird- rise is clearts shown by the water, which has not subsiled, althmuh the bird is tive feet or nore in the air. 


\section{WILD LIFE}

\section{AND THE CAMERA}

BY

A. RADCLYFFE DUGMORE, F.R.G.S.

Philadelphia: J. B. LipPincotT COMPany LoNDoN : WILLIAM HEINEMANN MCMXII 


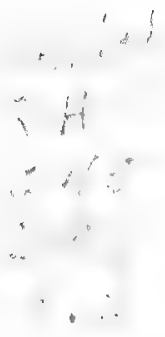

Printed in England. 


\section{CONTENTS}

CHAP.

I. Part I.-Btrd Photography . . . 3

Part II.-Animal Photography . . 16

II. The Caribou Migration in Newfoundiand 27

III. The Story of a Porcupine Hunt . . 49

IV. Birds and the Camera . . . . 63

V. "Bluey": A True Story of the very Best Pet Bird . • • . . 75

VI. My Chicadee Friends . . . . $\quad$ - 93

VII. The Warbler Family $\quad$. . . . 115

VIII. The Vireo and the Cowbird . . . 129

IX. Notes on the Breeding Habits of the

American Woodcock . . $\quad 139$

X. Shooting Wild Ducks and Geese witil THE CAMERA . . . . . 147

XI. The Whistling Swan of Currituck SOUND • . . . . . 157

XII. Two 'Possums and several Mistakes - 167

XIII. A Fishing Trip in the High Sierras of Caljfornia for Gilbert and Golden Trout . . . . . . 177

XIV. Yellow Tail Fishing off Catalina ISLAND . . . . . . 208

XV. Fishing for Sea-trout in New BrunsWICK RIVERS . . . . . 211

XVI, My First Saimon: a Fishing Trip to NEWFOUNDLAND . • . . 225

XVII. Salmon Fishing in Newfoundland - 237

XVIII, Alone up MT. Katahdin . . . . 257

XIX. The Heart of Winter . . . . 275

XX. More about Winter and the Tracks of the Animals in the SNOW . . . 287

XXI. The Life of the Trapper, the Man for WHOM Cold Weather is a SOURCE OF LIVELIHOOD

XXII. Camping for all Seasons $\quad$ - $\quad . \quad 307$ 



\section{LIST OF ILLUSTRATIONS}

Wild Mallard Rising . . . . Frontispiece TO FACE PAGE

Study of Young Birds at their most Becoming $\mathrm{AGE} \cdot$. $\cdot$, . . 10 Wood Thrush on Nest . . . . . 14 Newfoundland Caribou in migration . . 30 This herd of Caribou swam across the river DIRECTLY IN FRONT OF MY CAMP . . . 34

Evening on Sandy River. In the Foreground are two Caribou Which have JUSt CROSSED $\quad 36$ ONCE IN A GREAT WHILE THE HERD IS LED BY A STAG . . . . . . . . 40

Stag Caribou, photographed at a distance of not MORE THAN NINE YARDS . . . . . 42

The Porcupine and the Abandoned Camp in the SNOW . . . . . . . . 56

The Porcupine, the Man and the Half Dug-out • 58 The Unruly Brood of Flycatchers . . . 64 The same Brood Ready For Food . . . 64

The Tameness of a Family of Chipping Sparrows . 68 Young Red-Eyed Vireo . . . . . . 70 "Bluey" . . . . . . . . 80

Chicadee flying to My hand, IN Which Sit The Hungry Brood . . . . . . 108

Onr of the Young Chicadees . . . 110

The Worm-eating Warbler on her Nest • . 118 The Family of Worm-eating Warblers • • 122 Worm-eating Warbler feeding her Young on MY HAND . . . . . . . . 124

A White-eyed Vireo, Whose desire for ornamenTATION LED HER TO COVER HER BEAUTIFUL SEMIPENSILE Nest With SMall PIECES of Wood that HAD BEEN CUT BY A WOODPECKER . . . 130 W.I.C. 
Vireo's Nest, IN WHich a CowbIrd has LAId ITS EgG 132

TiHe SAME NEST CUT IN HAIF TO SHOW RELATIVE

positions of Cowbird's aNd Vireo's EgGS . 132

Woodcock Sitting on Nest . . . 142

Wild Canada Geese in Fisght . . . 152

Whistuing Swans off the Virginia Coast . . 158

"A LONG NOSE PROTRUDED FROM THE NEST" . . 168

'Possums. "Nearer and nearer he Came UNTIL

HIS NOSE WAS VISIBLE OVER THE EDGE OF THE

LARGE KNOB",. . . . . . . 170

Playing 'Possum-" Possum II. decided to have

A LOOK AND WITHOUT CHANGING HIS POSITION HE

OPENED HIS ROUND DARK EYES" • • " 172

The open PARI-LIKE dRY Country at the Foot-

ilills of the Sierras of Caltfornia • 180

Riding along the steep Slopes on the Way to the

Kern River. . . . . . . 182

The Kern River Valley . . . . . 184

Fishing in the Kern River . . . . 188

Volcano Creek . . . . . . . 190

Landing a large Gilbert Trout in the Kern

River (California) . . . . . 192

Sea-trout Fishing in New Brunswick . . 214

Leaping Salmon . . . . . . . . 240

LEAPING SALMoN; THE LINE IS FAINTI,y VISIble • 240

Mending a Canoe with Caribou hides in New-

FOUNDIAAND . . . . . . . 244

IN THE DENSE WOODS BELOW KaTAHDiN . . 260

"THE NORTH-EAST SIDE OF THE MOUNTAIN IS AN ABRUPT PRECIPICE OF SOLID ROCK ABOUT 4,000 FEET HIGH $"$. . . . . . . . 268

The Winter Woods . • . • • . 276

Tracks IN THE SNOW. THE DEEP FOOTPRINTS ARE THOSE OF A SQUIRREL WHICH WAS EVIDENTLY CAUGHT BY AN OWL OR A HAWK, WHOSE WING TRACKS ARE CLEARLY SHOWN . . . . 280

IN THE WINTER, WHEN EVERY TWIG IS COVERED WITH

A GLISTENING COAT OF ICE . . . . 282 
TO FACE FAGT

Tracis in the snow showing where a Musk Rat HAS COME FROM AND RETURNED TO THE WATER . 288 Tracks in the snow showing wiere a Mink has Caught a Musi Rat as it emerged from a hole IN THE ICE . . . . . . . 292 "Joe," tire one-armed Trapper and his Cabin . 300 "Joe," the one-ARmed Trapper . . . . 302 Camping in Winter With the thermometer $20^{\circ}$ beiow Zero . . . . . . 308 Winter Camping. Crossing a Snow-covered Lake 310 Winter Camping in Florida . . . . 318 



\section{BIRD PHOTOGRAPHY \\ ANIMAL PHOTOGRAPHY}

W.I.C. 



\section{CHAP'TER I}

\section{Part I \\ Bird Photography}

WHILE book-illustrating has changed continually since printing was first discovered, perhaps the greatest improvement has been made in pictures of birds and animals, and it is largely to the camera that we owe this great improvement. Until quite recently only drawings were used for illustrations, and with subjects such as birds "the personal equation" played so prominent a part that one felt a certain sense of doubt as to the accuracy even of fairly good drawings.

For my own part I had never been satisfied with drawings of birds; and therefore, giving up the pencil, I followed in the footsteps of those who were experimenting with bird photography. All my earlier attempts were with mounted specimens, at first without any accessories. But the photographs seemed hard and unlifelike. Then I tried placing the mounted bird in natural surroundings, either out of doors or beneath a skylight. The pictures were fairly satisfactory, but still there was no disguising the fact that the bird was mounted. The eyes, and usually the legs, told the story. The pictures were unsympathetic; it was as though 


\section{WILD LIFE AND THE CAMERA}

one had photographed the wax model of a friend. The likeness was there, but the life was lacking. And there was another objection: although to the casual observer the specimen may appear well mounted, how rarely is shown the characteristic pose so subtle and delicate in its infinite variety. But few taxidermists are naturalists, and without endless study of living birds how can anyone expect to know the attitudes assumed by the different species? The human eye itself is scarcely quick enough to take note of these things, and so it is to the camera that we must turn, and use it as eye, notebook, and pencil. It was the realisation of this fact that led me finally to try the fascinating but difficult task of photographing the living bird.

To begin with, only nestlings were my models, and I was delighted with the results-no glass eyes nor dried-up legs to mar the picture, but expressions as varied as they were beautiful, and positions entirely different from those seen in mounted specimens. These successes led me, of course, to attempt photographing the adult bird, and I made many experiments with tame birds. It was necessary to have a place arranged so that there might be abundant light; and to avoid sameness in the arrangement of the lighting, the contrivance must be movable. I made a wooden platform (supported on two light wooden horses) about six feet long, and covered it with mosquito netting stretched on a light framework. The background was of wood, to which could be attached paper or cloth of any desired shade. The camera could be moved backward or forward and secured with a 
tripod screw. Into this portable cage the bird was to be put, and as there was only one perch-usually a stick or small branch of convenient shape and size-I fondly imagined that the bird would sit pretty nearly where I wished. But I was doomed to disappointment. When I put the bird in, any place and every place suited him better than the perch so carefully arranged for his special comfort. When a bird, no matter how tame he may be, is placed amid new and unusual surroundings, he is at first greatly frightened, and therefore quite unmanageable. It usually requires some time to prove to him that the new cage will not harm him. So I found my cage not altogether a success, but by patience I managed to obtain some satisfactory photographs.

\section{The Sport of Photographing Wild Birds}

It was not long before I was led to attempt the task of photographing the adult bird in its wild state and in its natural surroundings. It was then I began to appreciate the fascination of the work. Looked at from any one of several standpoints, the photographing of wild birds will be found equally satisfactory. As a sport it should take a high place, for undoubtedly the skill as well as the perseverance and the instinct of the hunter is a necessary requirement, and a successful shot with the camera is far more difficult to obtain than a correspondingly fortunate (on one side only) shot from a gun. Then, too, the accomplishment of one's desire leaves behind it no disagreeable taste 


\section{WILD LIFE AND THE CAMERA}

to mar the pleasure. What sportsman is there (and I speak neither of pot hunters nor "game hogs ") who, hearing the death-bleat of a deer, does not at heart wish his shot had miscarried? Then, as a means of really becoming acquainted with birds, the camera is without an equal, for to be even a moderately successful bird photographer, one must have an intimate knowledge of the subject; and the camera, in teaching us to know the birds, must of necessity stimulate our affection for these useful and defenceless creatures. As a recorder of facts it is of great scientific value, for it cannot lie, and it records in an unmistakable form every detail presented, whether it be the daily growth of a nestling or the exquisite detail of the bird's nest.

It is, however, to the keen pleasure that may be derived from this new sport that I would particularly call attention. Not only is there the delight in overcoming difficulties (and they will be found both numerous and varied), but there is the pleasure of being placed among surroundings that are inseparable from this pursuit. A rich harvest of interesting facts relating to the bird's home life may be gathered by any observing person who spends much time along the hedge-rows or in the woods.

He who would hunt birds with the camera will find that without doubt the breeding season is the time best suited to his purpose, for then the feathered housekeepers are restricted in their individual range to a comparatively limited area. Having learned the situation of their house, he may find them at home when he calls, engaged in 
attending to their various domestic duties. The first thing to do after the introduction, i.e., learning their name, is to obtain their confidence, and, with birds as with people, there must be confidence if we wish friendship. How easily one may gain this confidence depends quite as much upon the individuality of the bird as upon the species. The fear of man is inherent in all birds, but by judicious management this fear can to some extent be allayed.

\section{Winning the Confidence of Wird Birds}

A great many instances have come before my notice of the change in a bird's behaviour from extreme fear and distrust to a degree of confidence, which, to the inexperienced, seems almost inconceivable. The power to tame birds or animals is thought to belong peculiarly to certain persons. This may or may not be true, but from my own observations I am inclined to believe that tameness is a quality rather of the natural disposition of the individual, bird, or animal.

With some birds I have spent days in trying to convince them that I intended no harm, yet they placed not the slightest confidence in me, and would not even feed their young if $\mathrm{I}$ were in sight. Others of the same species became accustomed to my presence after less than an hour, showing their confidence by coming to their young while I stood in plain sight, within a few feet of the nest. It is in the difficulty of familiarising the bird with ourselves and the camera that we 


\section{WILD LIFE AND THE CAMERA}

experience the greatest obstacle to photographing them.

Of the many delightful birds I have had the good fortune to know, the worm-eating warbler family, whose portraits are shown elsewhere, have afforded me the greatest pleasure, for they became absolutely fearless of the camera, and they placed a degree of trust in me that was as unusual as it was delightful.

'To photograph the nest containing eggs is usually a comparatively easy matter, as a long exposure may be given. The best results are obtained when a grey day is chosen, as the light is softer and more diffused, so that all the details, both of nest and eggs, are clearly shown. A very different task is the photographing of the young in the nest, and the resulting pictures are seldom what one hopes for. The reasons for this are obvious. The young are never quiet even when asleep, owing to their rapid respiration. This precludes a time exposure, and this in turn prevents the use of anything but a large diaphragm; therefore, as the distance from the near edge of the nest to the bird farthest away is several inches, only a small part can be in focus, while the rest is a blurred mass. If the light is sufficiently bright, the best results may be obtained when the nestlings raise their heads for food, as each bird is then more clearly defined, instead of being a part of a shapeless, heaving mass. This applies more particularly to the photographing of small birds, as the camera, with a lens of ordinary focal length, has to be placed very near the nest, with the 
consequent lack of depth of focus that is unfortunately inseparable from such conditions.

To photograph the parent bird sitting is difficult or easy according to the disposition of the bird, which varies not only with the different species, but with individuals of the same species. Usually the brown thrasher, the wood thrush, or the catbird will sit close, and allow the camera to be placed within a few feet of them while they are on the nest; but I have seen exceptions, which go to prove that success depends largely upon the peculiar disposition of the bird itself. People, as a rule, think that, because a bird builds its nest in the immediate vicinity of a house, it is necessarily tamer than one that chooses the quiet seclusion of the woods. This has not been my experience, for the tamest birds I have ever known were those that nested in places comparatively remote from human habitation.

When the fledglings leave their nest, the bird photographer should be on hand, for then it is that he can obtain the best pictures, as the youngsters may be put on any perch that best suits his fancy, and a place where there is sufficient light may be chosen. For the benefit of those who might wish to try their hand at this fascinating branch of photography I give the following suggestions:-

Select a branch or briar of suitable shape and size-and young birds prefer a fairly thick perch. This should be arranged so that it will not be swayed by the wind, lest the branch move and the birds be out of focus. Bright sunlight is necessary, as the exposure must not exceed one-fiftieth of a 


\section{WILD LIFE AND THE CAMERA}

second. With such a short exposure the shadows are likely to be lacking in detail, so it is advisable to place beneath the birds a white cloth, and this should be tilted to such an angle that the reflected light shall strike those parts of the birds that are in shadow.

If the natural background is not strongly sunlit, it will be an advantage to use a white or lightgrey cloth as an artificial background, but it should be placed at a reasonable distance from the birds; from four to eight feet will answer. Now place the little fellows on the perch and arrange the camera, remembering--if you wish to photograph the parent bird with her young-to leave sufficient space between the young birds and the edge of the plate, so that no matter on which side the old one comes to feed them the camera will be in readiness. All that remains to be done is to attach a long rubber tube to the shutter. Then sit down in an inconspicuous place and wait patiently until the old birds have fully convinced themselves that no harm is intended. 'Then they will venture near the camera and feed their hungry young.

Any one who uses the camera as a means of studying bird life will undoubtedly be surprised to find how marked is the individuality of birds. Not by casual observation does one discover this, but in the intimacy with the birds that one acquires when one watches for hours at a time the bird upon whose nest or young one may happen to have the instrument focused.

A camera, to be rigid and sufficiently durable to stand several seasons of field work, must be 


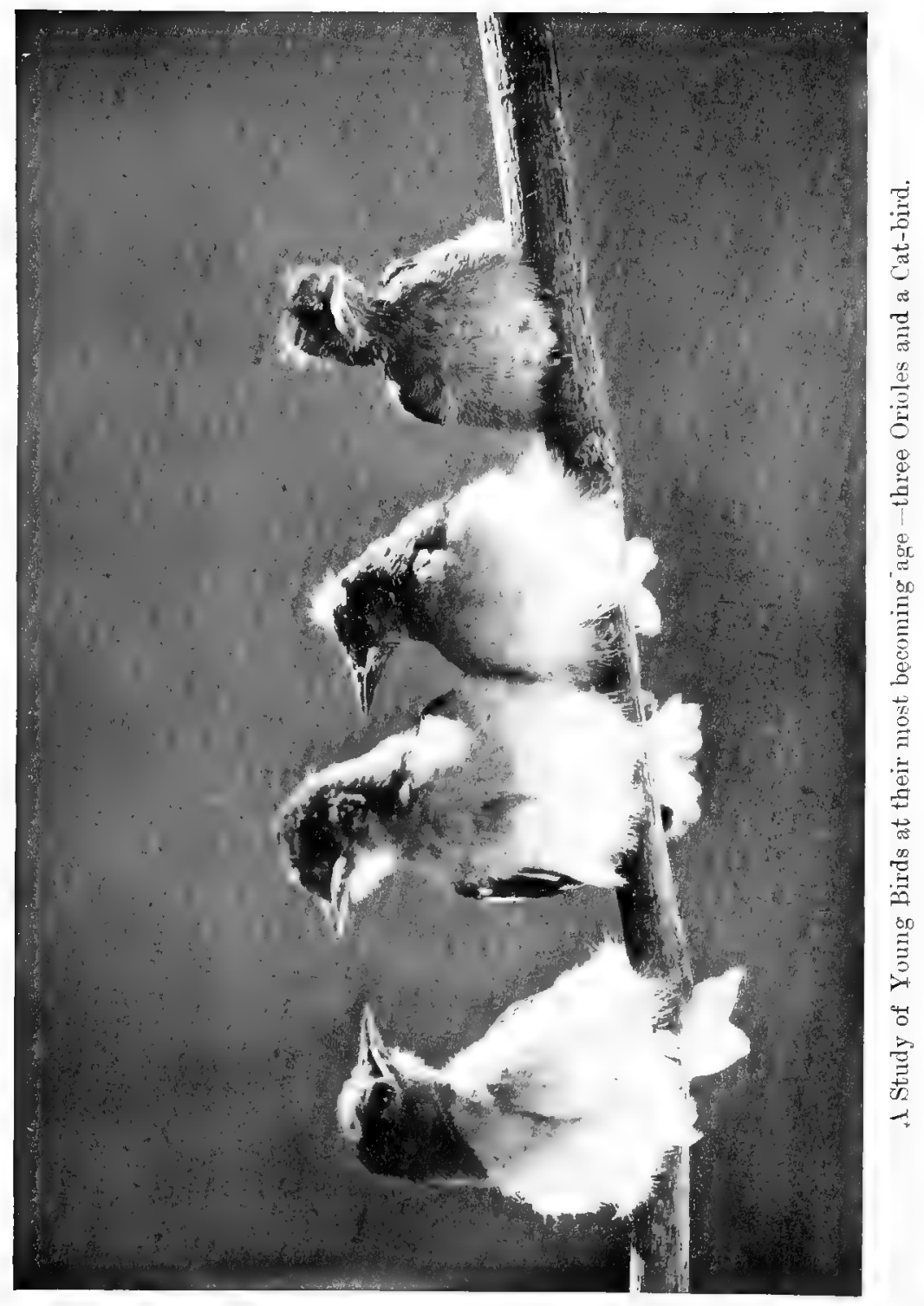



fairly heavy, though not of necessity large. A sufficient size for most work is five by seven inches, while some even prefer one as small as four by five. This latter is of convenient size for those who wish to have lantern slides made from their negatives, and is certainly far better adapted to all whose enthusiasm is limited, and who do not wish to overburden themselves.

For my own part I use the five by seven almost exclusively, and frequently I wish it were larger, particularly when the subject to be photographed is the parent bird feeding her young after they have left the nest. Place four or five fledglings on a branch, leaving sufficient space on either side to allow the old bird to stand, and reduce all this interesting material down to a five-inch space, and you will realise the advantage of even the extra two inches allowed by the five by seven. How many times has it happened to me to have the father or mother bird perch just outside the limits of my five by seven plate, and assume some attitude that I was most anxious to catch; and again how often has the plate through its limited size cut off part of the adult bird. In such cases I long for my larger camera which, on account of its weight, has been left behind.

Of course, bird photographs have to be taken under widely different conditions. Some birds are far less shy of man, and incidentally of the camera, than others.

It always seems surprising that a bird of such a nervous disposition as the wood thrush undoubtedly is, should be comparatively easy to photograph. 


\section{WILD LIFE AND THE CAMERA}

Thus far I have seldom found any that, while on the nest, would not, after a few attempts, allow the camera to be brought fairly near. For this reason, combined with the fact that they may be found so abundantly in the vicinity of dwellings, and that their nests are usually placed at a convenient height, they are most useful to the bird photographer. The birds themselves are so handsome and their markings so conspicuous that they show to the greatest advantage in a photograph, while such birds as the Baltimore oriole, the cardinal and others of equally brilliant plumage are very disappointing, as they lose greatly when shown in black and white. Take away their gorgeous colouring and we scarcely recognise them, while the wood thrush is unmistakable, whether depicted in black and white or in colour.

As an example of how a bird tries to conceal itself by means of its protective colouring, I will mention the case of a wood-thrush which I recently photographed. From the moment when she saw me coming towards her, armed with the camera, she never changed her position, but stood immovable, as though she were part of the natural growth, evidently believing herself to be unseen. At a distance of about seven feet I placed the camera, and throughout all the movements incidental to the focussing and arranging of things, she never moved, and I was therefore able to give the fairly long exposure that was made necessary by the strong light and shade. During the many times I visited her, only this once 
did she assume this peculiar position of imaginary concealment.

Another photograph was made in order to satisfy the doubtings of a disbelieving Thomas. The idea of attaching the camera to the higher branch of a tree and making the exposure with the aid of forty feet of rubber tubing was a story too far-fetched for my friend. To convince him that it could be done I selected a nest situated in a crotch of the upper branch of a maple and secured the camera to an adjoining branch about five feet from the nest.

The conditions were entirely unfavourable for photography, as the mass of leaves cut off the light except in front of the camera. However, a photograph had to be made, and so, after arranging things as best I might, I set the shutter for a three seconds' exposure. Then, descending the tree, I waited for the return of the mother thrush. She had throughout been watching the operations, with feelings closely akin to disgust, and when I removed my unwelcome presence to a little distance, she returned to the tree and abused the harmless camera as though it had been some frightful monster.

Finding it did not retaliate in any way and that it remained absolutely quiet, the excited bird soon quieted down and turned her attention to the hungry brood who called loudly for food. Such calls are imperative, and Mrs. 'Thrush went off in search of some desirable morsel. This she found after a very short time and with it she returned to the nest. Now was my opportunity and I pressed the bulb. Then, changing plates, I returned to the 


\section{WILD LIFE AND THE CAMERA}

dark room to develop what I hoped would turn out to be a good negative, but such was not to be; during the long exposure the bird had moved and so the plate was spoiled. Once more I returned to the tree, and after a short wait succeeded in making another exposure, this time with better results as shown in the accompanying illustration. Incidentally I may remark that my friend was convinced.

We will now turn our attention to photographing young birds being fed by their parents. This is, of course, no easy task, especially when the bird one wishes to portray is one like the Indigo bird, for the Indigo is not at all of a trusting nature. Man to them is an enemy to be avoided at all hazards. The gift of song together with the beautiful plumage of these small birds has been to them a living curse. Man, instead of being content to enjoy the presence of such ornaments amid their natural surroundings, must needs keep up a continual warfare against the harmless creatures, by catching them in traps, quite regardless of the law, and using them as an article of commerce. Years of such persecution have made them suspicious. Only in very exceptional instances do we find one that is at all tame. Many times have I tried, and in vain, to secure a photograph of the sitting bird on her nest, while the idea of her feeding her young with the camera in close proximity seemed nothing more nor less than a wild dream. One day, however, by good fortune I met with a family of Indigo birds that would pose for me. 'The young, usually extremely wild, were perfectly well behaved and remained whereever I chose to place them, but of the parents 


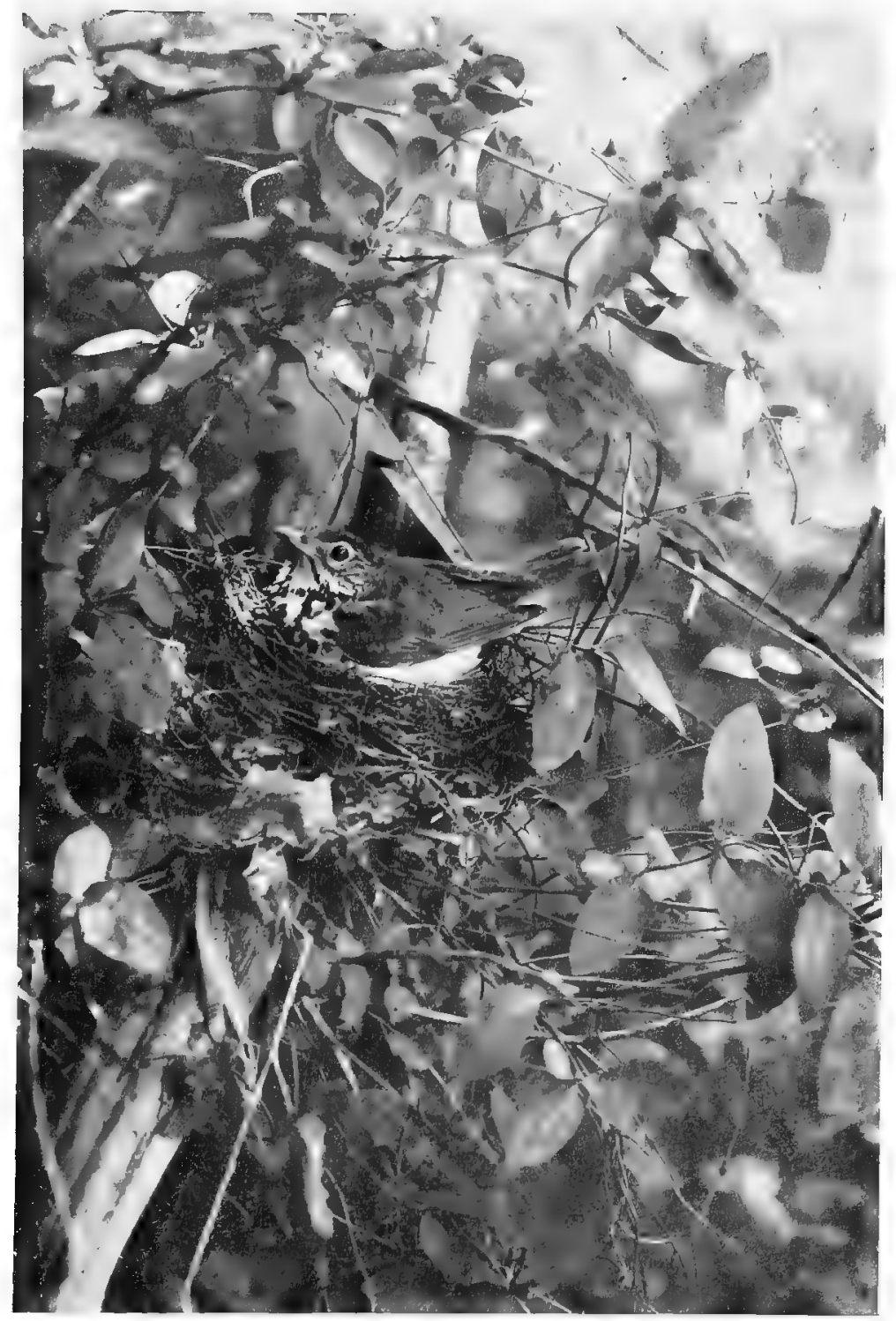

Tiond Thrush un Nest. 
only the dull-coloured mother bird would venture within shot of the camera, while the father, puffed up with vanity, for he is most wonderfully clothed in various shades of intense blue, would sit on the topmost branches of the trees near by and spend his time in song. All endeavours to induce him to come near the camera were futile. His dusky mate proved somewhat more tractable, and as long as I kept at a respectful distance from the camera, she did not seriously object to feeding her young ones. But the overwhelming combination of man and camera was more than she could stand, so while I succeeded in securing a number of photographs, in nearly every case I had to conceal myself in the underbrush and make the exposure through the long tube already mentioned. Towards the end of the second day she became rather less shy, but still she showed little of the confidence displayed by some other of my bird friends.

Spending so much time with birds affords one splendid opportunities for studying their habits, and with this interesting, if exclusive, family, the feature of their domestic arrangements that struck me most forcibly was, that not once did his lordship deign to carry food to any of his hungry offspring ; entirely to the industrious little mother were the youngsters beholden for their meals, and the number of grasshoppers, spiders, and caterpillars that she had to catch was quite remarkable. The only duties incumbent on her gaily bedecked lord, that I could discover, were firstly, that he must warn her of impending danger by uttering a sharp note of alarm; secondly, he must try, if the intruder 
happens to be of the human kind, to lead him as far as possible from the nest, which is carefully hidden in the tangle of undergrowth; thirdly, he must furnish amusement for the family by constant song. Surely his is the easier task.

\section{Part II}

\section{Animal Photography}

IT was quite natural that, after having devoted many years to bird hunting with the camera, I should become more ambitious and try my luck with larger and, shall I say, more interesting game? No; that would indeed be disloyal to the birds that first tempted me into what was then a virgin field. Each phase of the sport has its own particular virtues and attractions, its obstacles to overcome and sometimes its triumphs. Perhaps the chief difference between bird and animal work is that with birds, especially the smaller kinds, the great charm is in trying to overcome their natural fear of man in order to gain if possible their comparative if not complete confidence. No one who has not attempted this has any idea how much pleasure and satisfaction may be derived from the friendship of even the smallest and most common of wild birds. On the other hand, with animals there is seldom any question of friendship, except in rare instances and then usually only with the smaller species. The sportsman must be content with his joy in outwitting the keenly developed senses of the ever hunted, such as the deer, or of those equally alert, the hunters, the car- 
nivorous, great and small. You must match your intelligence, handicapped as it is by the somewhat dulled senses of seeing and hearing and the almost dead sense of smell, against those which have these three senses most keenly developed, and whose acute powers of reasoning should never be despised by the hunter. It is, as I have stated, difficult to say which pursuit affords the greater pleasure or keener excitement. Each is splendid and each will teach its many lessons to those who will but use their eyes intelligently and not jump to conclusions too hastily. Unfortunately this fault of hastiness is only too common, especially in two kinds of people, those who are too lazy to make their investigations without a sufficient degree of thoroughness, and those who by nature are impulsive and overenthusiastic. By such people, if they have but the suggestion of a theory on which to work, all incidents and conditions will be made to fit this pre-established theory; their eyes are blinded to all else. Mole-hills are turned into mountains and conclusions will be reached which have not the slightest foundation. No one has a much better opportunity to study wild animals in their native state than he who hunts with the camera. Unlike the man who shoots and so destroys the actual subject of his study, the camera-hunter is frequently forced to spend many, many hours of enforced inactivity whilst in the presence of the animals, waiting, perhaps, for them to come within range, to reach a place where stalking would be possible, or where the light will be good-waiting in fact for any of a dozen possible things to occur.

w.L.C. 


\section{WILD LIFE AND THE CAMERA}

It is during such times that the lessons are learnt, that the unexpected events take place. The actual photographing takes very little time, but the watching is never ended for those who really wish to observe and learn.

"What sort of camera should I use?" How often have I been asked this question, and yet it is always equally difficult to give an adequate and comprehensive reply. (1) What sort of man or woman are you? (2) Where are you going to hunt? (3) What are the conditions? (4) And finally, what can you afford for the outfit? These are perhaps the principal questions, and the answers are determined by further questioning. (1) Are you lazy or painstaking? If lazy and still insist on hunting with the camera (though in this case it would be quite against my advice that you should engage in a task, or sport, that depends so much on energy and perseverance) I advise an ordinary hand, folding camera, using films. The pictures you will obtain won't be worth much but they will be all you deserve. Are you painstaking? Then we shall have to answer the other questions first. (2) If you would hunt in the north, a telephoto lens of moderately high power need not be considered. If in a thickly-wooded country it is also of little or no use. Perhaps you are surprised that I should deal with the lens before speaking of the camera, but that is reasonable, for the camera must be of type suited to the lens or lenses you expect to use. (3) Is weight an important item? If it is, plates will have to be eliminated or practically so. Are you going to work from a horse or from a 
canoe, from a blind or by stalking? On the consideration of all these points depends the selection of a proper outfit. Generally speaking, the reflex type of camera is almost a necessity when good results are desired. Its size must depend on what you can use under the existing conditions. A four by five, or even a quarter plate size when light weight is called for. The five by seven, or the half plate, if it can be managed. These larger sizes are far more satisfactory, but are, of course, more expensive, more bulky and much heavier, and stalking with them is made very much more difficult. The very rapid lenses, that is, those working with an aperture of F. 4.5, or thereabouts, have so little depth of focus that it nearly always means cutting them down to about F. 6 in order to obtain even fair depth. So the extra weight is being carried to very little purpose, such as a quite occasional exposure under poor light conditions. F. 6 is quite large enough for most practical purposes. The new types of low and usually singlepowered telephoto lenses promise great things. They are being changed so frequently that before this appears in print some new device may be invented which will completely revolutionise everything. The chief (and almost only) advantage possessed by these types is that with a camera having only a short draw (of bellows) you can use a lens which has approximately an equivalent focus of twice the length of bellows. Against this, if they work at an aperture of F. 5 or 6 , there is the disadvantage of size, both in diameter and length, which makes them somewhat cumbersome. If you can 


\section{WILD LIFE AND THE CAMERA}

use a convertible lens of 2 foci, it is advisable, for though the single combination is slow it often enables you to obtain satisfactory pictures of animals entirely out of range for the ordinary short focus lens. But don't lose sight of the fact that the single combination means double the draw of bellows required for the complete lens. It is well to employ a lens, especially if it be a cheap one, made to cover a plate one size larger than you are using, so that there is no question of the entire plate being clean cut. The ordinary lenses supplied with cameras are usually too slow for animal work, their aperture being as a rule about F. 8. However, they will do quite well under favourable conditions, but don't forget that favourable conditions are the exception rather than the rule, except in such countries as Africa, or in the middle western states of North America. It is nearly always poor economy to buy cheap outfits. They too frequently lead to disappointment, and when you consider how much a trip costs, is it worth while for the sake of saving a very small amount to sacrifice the entire results, when by having a good reliable outfit you may secure pictures which will pay a part, if not all, of the expenses of your outing? Should you wish to go in for telephoto work remember that the positive lens should be of very great rapidity, not less than F. 4.5, otherwise the possibility of instantaneous exposure would be limited to one or two magnifications. Never buy the two elements separately, but let the manufacturer supply you with the complete lenses, positive and negative elements properly adjusted. It is 
essential that the camera for telephoto work should be very rigid, as the slightest vibration is greatly magnified.

Before touching on the practical use of the camera there are several details to be dealt with-small ones, but nevertheless important. Let the camera be in every way as simple as possible, free from complicated adjustments and all its parts easily accessible in case of anything getting out of order. Let there be as little outside machinery as possible. Every projection offers a chance for trouble; a slight blow, and perhaps the whole outfit may be rendered useless. All parts should work easily and with as little noise as possible. One of the great objections to the focal plane shutter is the noise it makes. The ideal camera could be reflex with both focal plane and lens shutter, the former for very rapid work such as birds in flight, and the latter for slower exposures where silence is all important. There is at present a reflex with a lens shutter, but it unfortunately does not allow much variation of lenses, so that its usefulness is greatly curtailed. The reflex camera should be so arranged that the focussing hood admits of use from above and from the back. The advantage of this is that it allows the camera to be held level with the eyes so that the immediate foreground is not shown in the picture. When you are in a canoe you can operate this camera with greater freedom and safety as it will not be necessary to stand up or even to kneel in order to clear the adja . cent water or the canoe bow which so often obtrudes itself in such pictures. Good plate holders are of the utmost importance; not only must they be abso- 


\section{WILD LIFE AND THE CAMERA}

lutely safe, and allow the plates to be easily put in and securely held in place, but they should be fitted with a device which precludes all possibility of double exposures, that bête noir, so common when one works under conditions of keen excitement and haste. In saying that plate holders should be loaded without difficulty, it must be borne in mind that when in camp you have no dark room, but usually a simple dark changing bag, which means manipulation by sense of touch alone, so it will be seen that any complications add greatly to one's troubles. Many prefer to use films instead of plates. There is no question at all of the advantage the former possess in point of weight and simplicity, but the results are not as satisfactory as when plates are used, especially so with the larger sizes. A five by seven or half plate film is very apt not to lie flat; in dry climates this is not so noticeable, but in damp, muggy weather they are more than likely to wrinkle, which means that with a very rapid lens (i.e., one that has little depth of focus) parts of the picture will be sharp while other parts on the same plane will be entirely out of focus. Then again, films are more inclined to have scratches. They do not keep so well, and, finally, they are not so easy of manipulation. Let me suggest that a soft, portable case be carried for the camera, made of some good strong but light waterproof material, so that in case of showers the camera will not suffer. The strong, stiff travelling case may be made of compressed paper, kept thoroughly varnished. It is better than leather, being lighter, stronger and more rigid, besides which it will not 
become water-soaked. Cases for plate holders should be made of the same material but covered with waterproofed leather so as to be less noisy. A small case of soft leather to hold three plate holders will be found very useful for carrying a temporary supply while you are actually stalking.

The foregoing is but a brief outline of the most important parts of the outfit necessary for animal photography. Each person who attempts the sport will, as he advances, develop his own ideas on what will best suit his methods. What has been said here is simply a general guide for those who are unfamiliar with the subject, so that they may have a basis on which to work when the outfit is to be bought. It is seldom that the dealer is able to offer much help in the way of advice regarding any special class of work. It is, indeed, scarcely to be expected of him, when we consider how difficult it is for the man who has spent years at the work to give advice that will be of much real value. Experience is the only trustworthy teacher, and she is so slow and usually so expensive that she is likely to discourage those whose heart is not thoroughly in the work they wish to do.

I make no mention of flashlight work because no device that $I$ have yet seen or made is worthy of being recommended. 


$$
\text { . }
$$




\section{THE GARIBOU MIGRATION IN NEWFOUNDLAND}





\section{CHAPTER II}

THE CARIBOU MIGRATION IN NEWFOUNDLAND ${ }^{1}$

[The result of six seasons' work, when patience was at last revarded and the big herds came before the stags had shed their antlers.]

ОстовеR 24TH, 1911. Once more I find myself in Newfoundland watching from my blind for the elusive Caribou, and, judging from indications, 1 shall not have long to wait. The day before yesterday while paddling up the river I saw several small lots of Caribou, and this morning while cooking my solitary breakfast, a herd of fifteen swam across the river and landed on the bank directly opposite my camp; so it looks as though the migration for which I have long waited had really begun, and that I would at last have some luck. Yesterday I repaired the blinds which $I$ have used each year, and built a couple of new ones on very promising leads, so $I$ feel that $I$ am ready for my friends when they come. Armed with camera, plates, and warm clothing I left camp soon after the sun had risen. After showing itself for a few minutes it retired behind the deep grey clouds. I circled around the river to my blind so as to leave no scent along the Caribou leads, for unless pressed by bad weather, these animals will not cross a fresh human trail, and even if the scent be almost cold

1 First published in Country Life. 
their suspicions will be aroused and the chance of securing pictures greatly reduced. It is only when they are absolutely off their guard and unsuspicious that one has any chance with them. To-day the wind is favourable but bitterly cold. Unfortunately the light is bad, but then that seems to be the rule at this time of the year in Newfoundland, bright days being rather the exception. My blind, or gaze, as the Newfoundlanders call it, is a simple affair composed of about a dozen small fir trees stuck securely into the bog, arranged in a circle open at the southern end; on the north side, facing the leads, the branches are cut away, leaving an opening through which the camera protrudes. The selection of a desirable site for the blind is of the greatest importance; it should control as many leads as possible, the prevailing direction of the wind must be considered, the sun must be from the back, the background should compose well, and there should be no obstructions in the foreground. Inside the blind everything should be arranged so that no dry twigs will rub against one's clothing, for the slightest noise may cause the loss of a picture. A number of well-worn leads or paths pass on each side of the blind I have made, some only a few feet away, others two or three hundred feet. All the conditions are such that if the Caribou come I shall be almost certain to get pictures.

The day wears on, but not a Caribou appears. I have been doing some sketching, but the cold wind makes the work very trying. The afternoon is particularly dark and unpleasant, and as it is nearly four o'clock I shall head for camp without having 
used a single plate. On my way down the river two small herds crossed far ahead of me.

Another day. Since eight o'clock this morning I have been in the same blind but without accomplishing anything. In the distance I have heard the splashing of animals crossing the river; why it is none come along these fine leads it is difficult to understand. Before returning to my camp I shall examine the banks and find out what leads are being used. The result of yesterday's search showed that the Caribou are using the leads below my camp, quite a number having crossed the river during the past few days, so this morning finds me in a new blind on the south side of the river. Unfortunately the wind is blowing so hard that it is impossible to hear any animals entering the water. Therefore it is all the more necessary to keep my eyes open. For two hours I have been waiting, and my hands and feet are becoming numb, so I must get up and start the blood circulating; but wait, there is a Caribou. It proves to be only a doe and her fawn, a beautiful pair almost entirely clothed in their winter coat of silvery white. They came along at a quick walk, heading directly toward me, closer and closer, until within forty feet or so. Owing to the lack of light it was impossible to make a picture of them walking, so that as soon as everything was ready, I gave a sudden shout. They stopped immediately, and as they looked about with a surprised expression, the shutter clicked with a noise that revealed my position, and off the pair went at full gallop. 'This little excitement warmed me up a trifle, but the cold is getting more and more intense and the sky 
becomes still more heavily obscured with cold leadcoloured clouds. Bad weather is coming without doubt. If only it would snow there would be no lack of Caribou. Even while I am writing, occasional snowflakes fly past, stinging my face. Further writing is impossible to-day. At intervals during the night flurries of hard snow blew against my tent, yet altogether there was scarcely enough to whiten the ground. The day broke dull and grey, but before nine o'clock the sun came out. Now if the Caribou would only come, the light is good and there is so little wind that any animals crossing the river can be easily heard. A Canada jay is sitting upon a twig above my head. He seems to be watching the pencil with wondering eyes. Down he comes; now he is not more than a foot or so from my head. Who's there? Well, that certainly beats anything I have ever known for impertinence. Evidently it was my glasses that fascinated the bird, for he suddenly darted at them and had them in his bill before I realised his intentions. Throwing up my hands, I frightened the rascal, and he dropped the glasses Before I could replace them the stillness of the morning was broken by repeated sounds of splashing in the river. Caribou had crossed and landed close to where my canoe was hidden. Fortunately they kept clear of my trail. It was only a small herd, but they came within range and I made two exposures. Scarcely had I reloaded the camera than another and larger herd came into view. What a superb sight they presented as they walked with quick steps along the lead which would give me the best chance with the camera! 


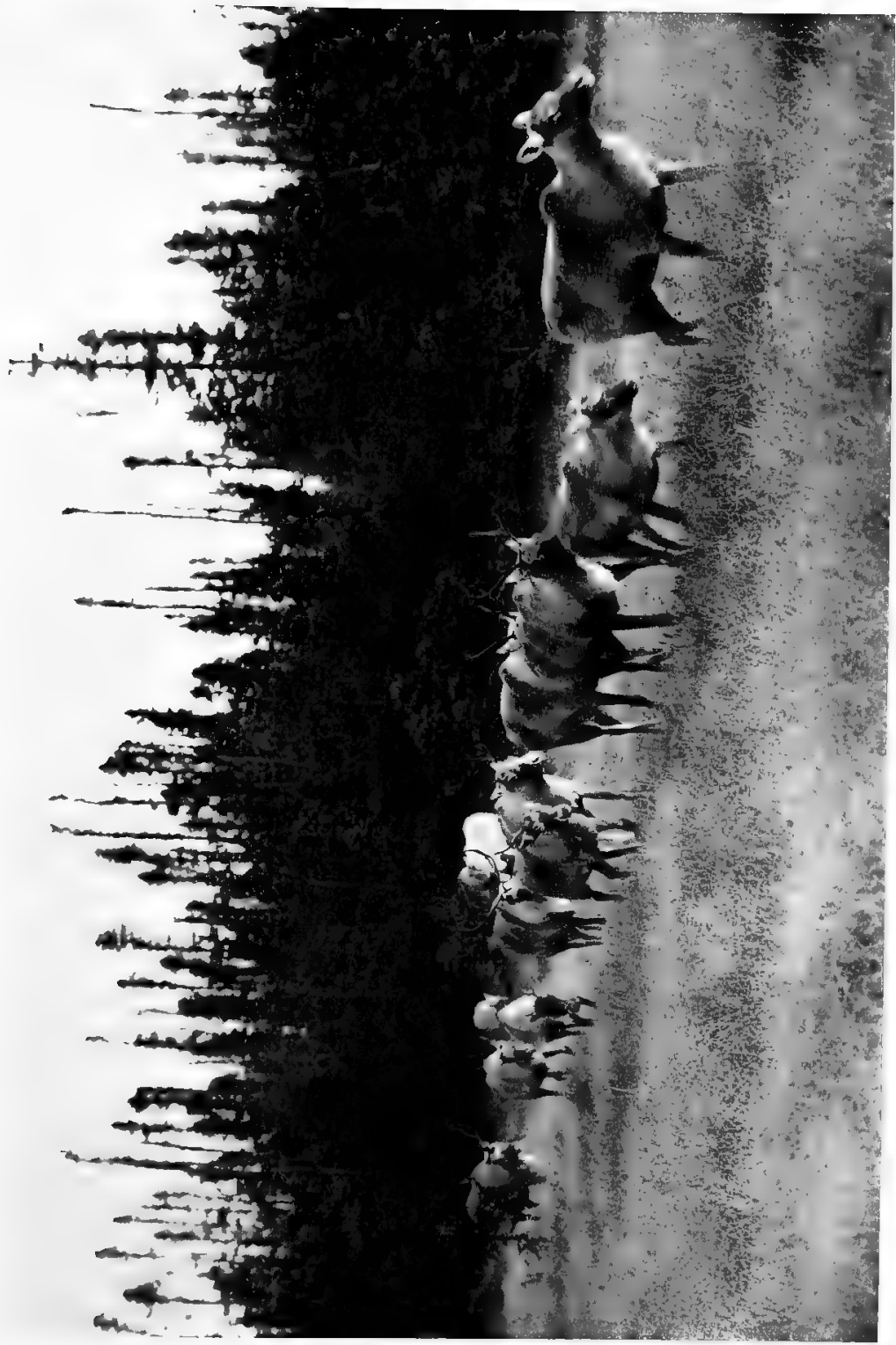

을.

का 80

है 5

古

+ 总

i $\stackrel{0}{=}$

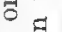

0.0
+00
0.0

$+98$

$800+$

.

눙

密

क

녕

बह

따

들

회.

켝

苧

bo 1.

공

(5)

正

옹

赵宁

50

घ도

- 등

. $\exists \frac{0}{80} \stackrel{\mathrm{E}}{\mathrm{D}}$

․․요

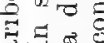

○ण

룽

雪罚

चु

है

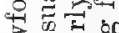

$5 \approx$

品品

멸

얼 

So quiet was the morning that the curious clicking of their feet sounded unusually clearly. Here was the chance for which I had been waiting six long years. The combination that I knew was bound to come some time; good light, and a large enough herd of absolutely unsuspicious Caribou. It was really worth waiting for, and my heart beat so hard with excitement that it seemed as though the approaching animals must hear it. With almost feverish haste each part of the camera was carefully examined to see that the shutter was set correctly, the proper diaphragm in place, the slidedrawn, and so forth. All of this occupied but a second or two. However, the animals were almost in range by the time I had made sure that everything was in readiness. If only a stag had been leading! But that seldom happens. In fact, only three times have I seen it! First came a doe and her fawn, then three young stags and another doe followed by a fair stag, but the largest one was, of course, the last of the line; that is the rule and that is why it is so difficult to photograph them. On they came, and I watched them closely as they grew larger and larger on the ground glass of the camera, but at the moment when they almost covered the entire plate, I pressed the shutter release, the picture was made and the herd had gone before another plate could be put into position. Now once more I settle down to watch and think with pleasure of the good luck that has come my way. It has been a satisfactory day's work, even if I get nothing more, but apparently there is more to come, for at this moment I hear splashes. What is to be? There 


\section{2

comes a head through the fringe of alders which line the river bank, another, and yet another. This is surely my lucky day. Among that small herd was a stag, a real stag of the kind one reads about, but seldom sees. How many points? you ask. Well! I don't know. I didn't have time to count them, but it looked like forty-five or fifty, and the photograph shows a full forty-five. He followed close behind the small band of does and came within fifty feet of me before I made the exposure. Startled by the sound of the shutter, the big fellow jumped directly towards me, stopping about twenty-five feet away. Excited to a painful degree, I tried to put in another plate and reset the shutter so that I might make a picture of the stag alone. But just as I was drawing the slide, he galloped off. I had secured one picture of the magnificent specimen, so I had no right to complain. Yet I did regret not having succeeded in getting the picture of him alone, when he would have shown to much better advantage.

It is afternoon and the sky is dull. So far nothing has happened since the big stag came. Several Caribou are feeding on the marsh a few hundred yards away. One small herd is working in this direction. They are feeding slowly along. Now they are not more than one hundred and fifty yards away. They have stopped feeding, and one after the other they are lying down. The stag, a fine big one, stands sentry for some time, but he too wants to rest, so he too lies down. For over an hour they sleep quietly. One old doe looks up occasionally, but they are unaware of the fact that their arch- 
enemy, man, is so near. Suddenly, however, three does came along so quietly that I neither saw nor heard them until they were within about twenty feet, and without having seen them, I moved. Of course they bolted, giving, as they went, the alarmcall which aroused the sleeping herd and caused them to take to their heels.

This is a morning of mornings. The whole country is a fairy land, glistening and sparkling with a wonderful covering of iridescent hoar-frost. The dark, oily water of the river seems doubly dark as it glides along the white avenue. The edges are coated with frost-covered ice, and small clusters of frozen froth float slowly and silently down the river. The overpowering silence is broken now and then by the harsh croak of a raven or the whistling of a passing duck. It is on a morning like this that one appreciates to the fullest the joy of being entirely alone, and yet people so often ask me if I am not lonely on these solitary trips. On such a day as this, loneliness is impossible. The barrens surrounding my blinds are particularly and wonderfully beautiful this morning. In one part the yellow grass gives a curious golden hue to the frosty covering. In another the colour is pinkish-purple, as richly coloured leaves shine through the frost. Look which way you will the effect is different, yet equally beautiful. But it is too good to last. A cold wind is getting up, dark clouds are gathering on the horizon, bad weather is threatening. It is about noon, and even now large drops of rain are spattering the paper, so I must stop writing. Yesterday brought no luck. The weather became

W.L.c. 


\section{WILD LIFE AND THE CAMERA}

unbearable, and at 3 o'clock I gave up and returned to camp. By 5 o'clock it was snowing hard, and all night the soft flakes pattered gently on the tent, each one adding to my hopes. When I got up this morning at 5.30 the moon was setting in a clear sky. The country looked as beautiful as it always must when the evergreens are snowcovered. Not a breath of wind stirred the trees, and everything was so exquisitely quiet that it seemed an act of sacrilege to break the stillness with the sound of the axe. This snow was bound to bring the Caribou, and I hurried through breakfast, scarcely waiting even to share my porridge with my favourite Canada jay. With disgust I saw the sky becoming overcast, and before I left the camp a film of grey had hidden the blue.

Now I am once more in the whitened blind, wishing the sun would come out to make the snow sparkle and help me with my photographic work. There! I hear a splash in the river not four hundred yards away. Another and another, in quick succession. It is Caribou, and they are evidently going to land at the leads which I am watching. Everything is ready but the light, which is pitifully bad. They are coming. What a herd that was! Fully seventyfive, with many good stags, but they came so fast, as though impelled with the fear of bad weather, that a quick exposure was impossible. Nothing could stop the maddened herd and they rushed past me within a few feet, the band separating as they reached the blind, going so close that $I$ could put out my hand and touch them as they pass. Exciting! It certainly was. It was exhilarating, and 


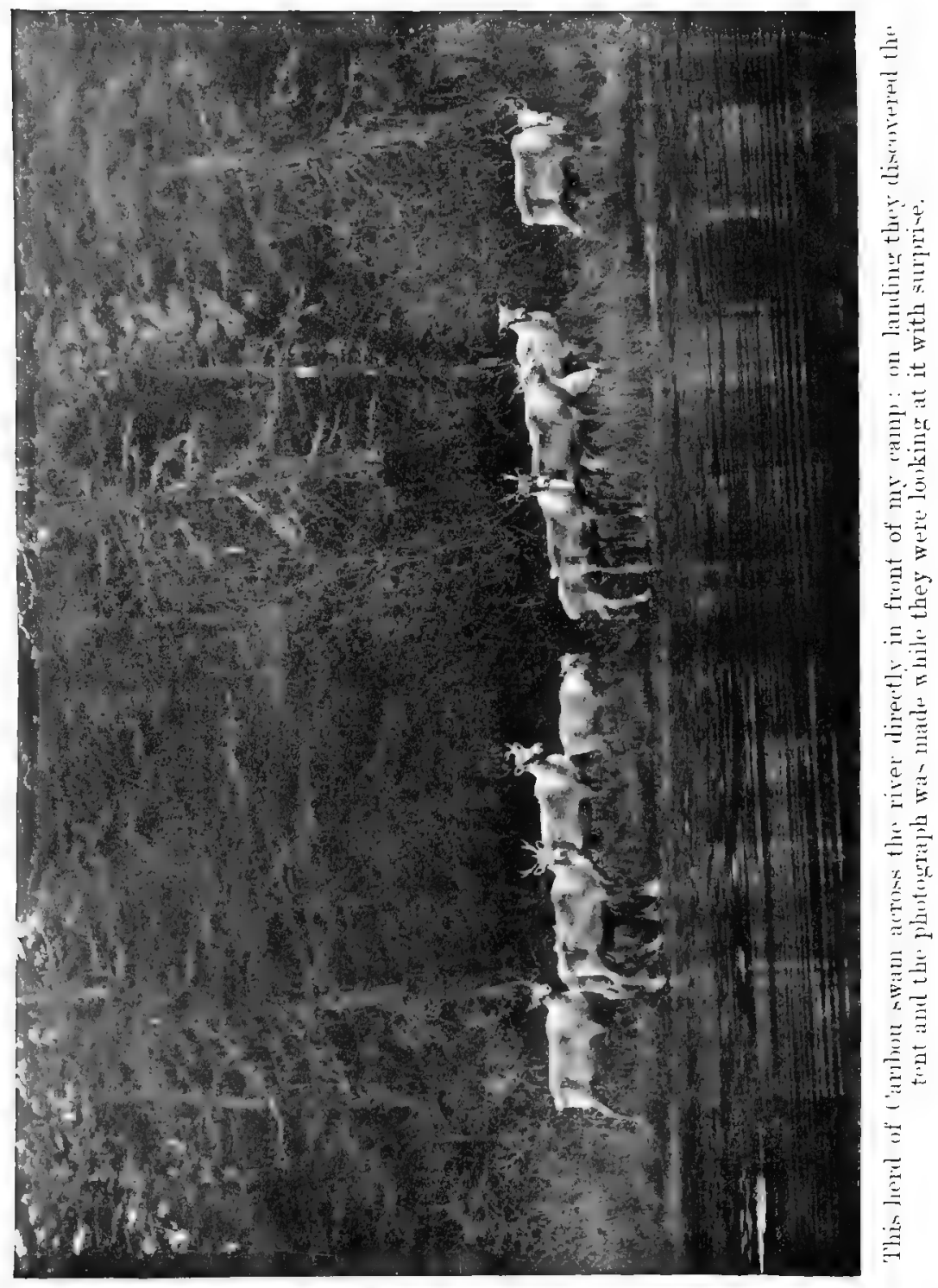




$$
\text { - }
$$


even though I got only one very poor picture, the experience was one long to be remembered. What would I not have given for a gleam of sunshine. Then I could have shown people what a herd of frenzied Caribou look like. Wait! There is another splash. It was only a single stag, a rather small one with poor antlers, but he came very close, and as he was travelling slowly, I managed to secure a fair picture. The wind is rising and blowing away the snow from the more exposed situations. This is bad, as it makes it still more difficult to use the camera for quick work. Once more I hear a terrific splashing in the river, but it sounds a little below my leads. Minutes are going by. Still I see no sign of the animals. They have evidently gone along another lead further to the westward. Yes, I can see them crossing the big marsh. A superb herd of one hundred and twenty or more. What a pity they are too far away to photograph! It is such a beautiful sight, that long, quickly moving line of white and grey, its colour being in perfect harmony with the snow-mottled marsh where the colours range from the deepest crimsons and yellows to cold blue and lemon greys of the Caribou moss. There again is the promising sound of splashing in the water, repeated at short intervals as animal after animal takes to the river. The wind makes so much noise that it is impossible to get any idea of the number in the herd, but I shall probably see them, as they appear to be coming this way. Yes, there they are. The herd was a big one, but it divided and only thirty or forty passed me, and not a stag in the lot. For some unknown reason the 
big part of that herd with several fine stags turned off from the main lead soon after leaving the river bank, so the picture of the does was all I could get. It is surely hard luck to see so many Caribou and not be able to make satisfactory pictures. But, after all, that is the peculiarity of animal photography. There is always some obstacle in the way of making good pictures. It is these difficulties and disappointments which make the sport so fascinating. How much more difficult it is than shooting! Here this morning I could have shot several fine stags, but not a single good picture of one could I secure. Several hours have gone by and many Caribou have passed, large and small herds. But most have gone so quickly that with the poor light I could not photograph them. A few came more quietly, and with these I had fair luck. Now it is too dark to do anything more. In point of numbers this has been the best day I have ever known, over five hundred having passed within sight, but the results pictorially have been very unsatisfactory. Before leaving camp this morning three herds of Caribou crossed the river, one lot crossing by my camp, but though the light was weak, I managed to make a long enough exposure to secure a rather satisfactory picture. No sooner had I reached my blind than a large herd came by, going too fast to be photographed. Later on several herds crossed further below, but they did not come within range of the camera. The day is very dull so I have small hopes of doing much, especially as most of the herds are working further to the westward. One small company led by a fairly good 


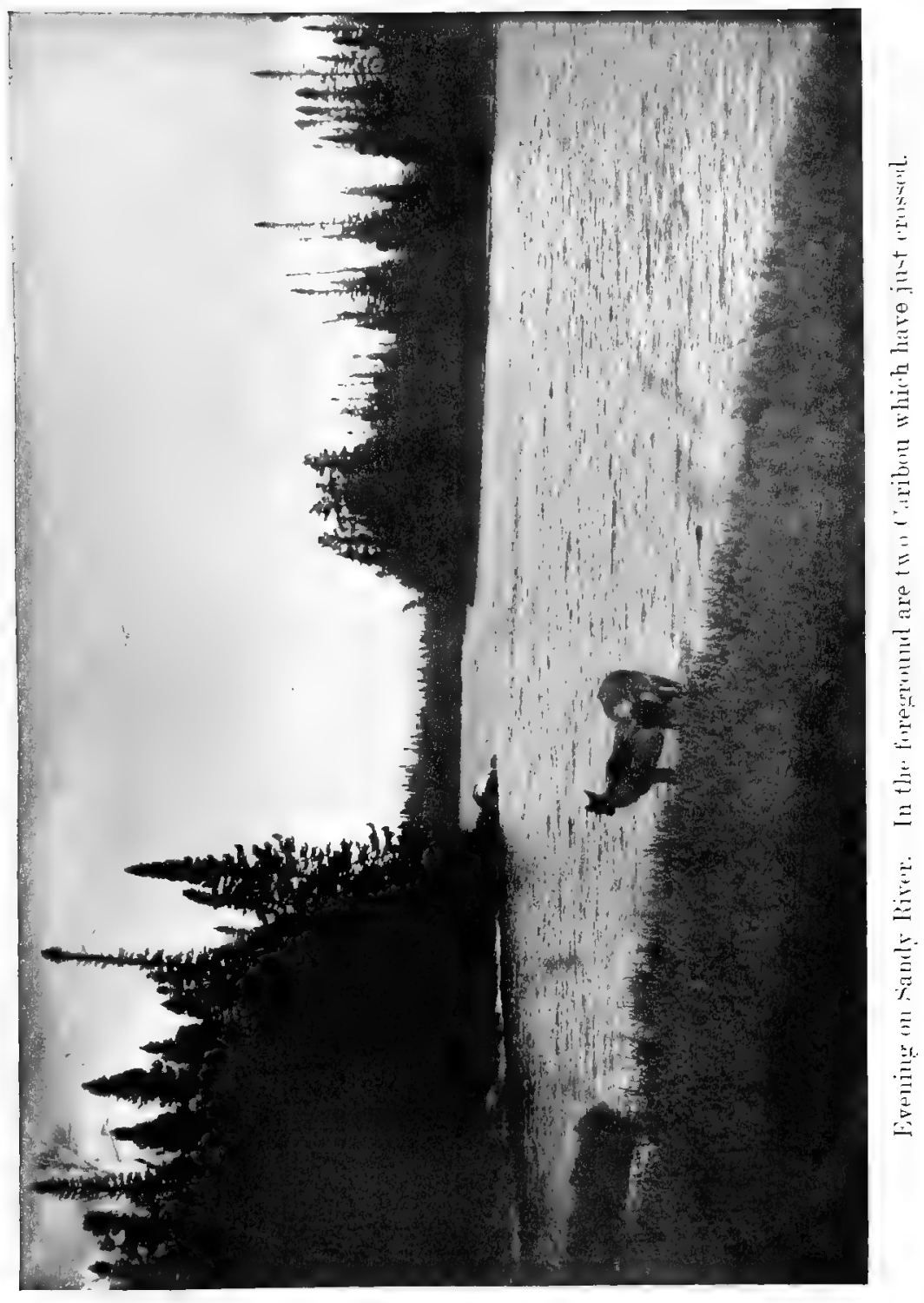



stag came within reach, but the weak light made it impossible to make a satisfactory picture. Towards noon the day warmed up, and the Caribou, after crossing the river, entered the big marsh and stopped there to feed and rest. At one time I could count eight separate herds all within three-quarters of a mile. About three hundred yards away there were three large stags, and I attempted to stalk them. Unfortunately I had not seen a doe that evidently belonged to the party, and just before I got within range, she warned the stags and off they went. About three o'clock I went back to the river to try my luck there, and soon found one of the much used crossings. A few minutes after I had hidden myself among some tall grass, a single doe swam the river and landed immediately in front of me; with the bright golden light streaming through the clouds it was very beautiful, but exasperating, as it was not in good position for the camera. I made an exposure and the animal passed me within twenty feet without even suspecting my presence. A few minutes later a doe and a fawn landed at the same place, and I could not resist the temptation to use another plate.

To-day I tried working along the river in the hopes of getting photographs of the Caribou entering and leaving the water. Hiding among the tall grass as I had done yesterday, I did not have long to wait before a large herd appeared on the opposite bank. After hesitating for a moment or two, they broke through the thin sheet of ice and entered the river, following closely one behind the other till there were forty in the water, but 


\section{WILD LIFE AND THE CAMERA}

they headed down stream, far below where I was until suddenly, without any apparent reason, they turned and came straight toward me. The sun was still so low that the fir trees cast a shadow far across the river, but as that could not be helped, I had to make the best of it. The herd landed about forty feet from me and I made two exposures before they realised what was happening. Then what a scattering there was! Mud flew in all directions and many rushed past, only a few feet away. After this I crossed the river to the sun-lit side; putting the canoe behind a partly submerged log, I waited, and pretty soon a doe and fawn came down the bank and, entering the river, swam across without seeing me. Soon another pair posed for me. Then a little later there was a great commotion as a large herd came crashing down the bank through the thick fringe of trees. Now the question was when to take the picture. Of course, I wanted a big stag as the centre of the picture. Does and small stags came in abundance, and finally I thought the last had come, and even though it was only a doe I pressed the button as she rushed down the bank. No sooner had I done this than an immense stag came immediately behind her, hesitated a moment in a perfect position, looking directly at me, but before I could re-set the shut, he had scrambled up the bank and disappeared. For the rest of the day I had no further luck. Many Caribou crossed the river, but all went below or above where I happened to be. Nevertheless, the day has been one of great interest. It is seldom that one has a chance to see so many 
wild animals, and while watching them the wonder of this great migration was constantly before my mind. Every autumn, following the first heavy snow that comes after October 20th, the northern Caribou commenced the southerly journey; converging from their various summer haunts, they pass between Sandy River and Gaff-topsails, scattering again soon after they cross the railroad line to grass. The winters are spent toward the centre of the island. Then, as spring approaches, the great herd return to their summer homes. In watching the southerly migration one is surprised at the great number of does, perhaps as many as fifteen or twenty to each stag. In fact there are often large herds with no stags at all. This inequality is not as great as it seems, for toward the end of the migration there are many great herds which contain only stags, but then they are mostly without antlers. As early as November 3rd some of the stags drop their horns, very few carrying them into December. At what age the Caribou carry their best heads is not known, but probably the largest horns are found on the stags ranging from seven to ten years of age. Unlike most deer the does of the Newfoundland Caribou usually have horns. They are for the most part small and without beauty, though occasionally a very fair head is seen; in form it is more like the antlers of the Virginia deer, and lacks the characteristic brow paddle, which the stags almost always have. The Caribou's colour varies with the individual and with the season. In general they are white in the winter and a soft brown or grey mouse colour 
during the summer. The cause of the migration is presumably the search for food, but there is so little data on the subject that one is scarcely justified in making any definite statements. We know that by no means all the northern Caribou come south, many remaining in the extreme north of the peninsula; while quite as many stay in the southern part of the island during the summer. There is no apparent reason why those animals which spend the winter in the middle of the island on the high plains and rolling hills should not stay there during the summer. Evidently there is some condition of which we know nothing, something which causes the vast herds to endure the hardships of the long trips of the autumn and spring, when they often have to fight their way through the thick ice of the frozen rivers and lakes. They travel easily and rapidly under almost all conditions, gliding over the soft, quaking bogs as readily as over the hard, rocky hills. Through the dense fir forests they break their way almost without noise. They take to the water like ducks, their heavy coats of air-containing hair making them so buoyant that they swim with several inches of the entire length of their body showing; but though they swim with ease and rapidity, they do not relish entering the very cold water. I have often watched them hesitate for quite a long time before plunging in. The leads or roads which they follow have been in use year after year, perhaps for hundreds or thousands of years, for in many places deep furrows are worn in the rocks by the hoofs of countless thousands of Caribou. Travelling, at least in the autumn, 


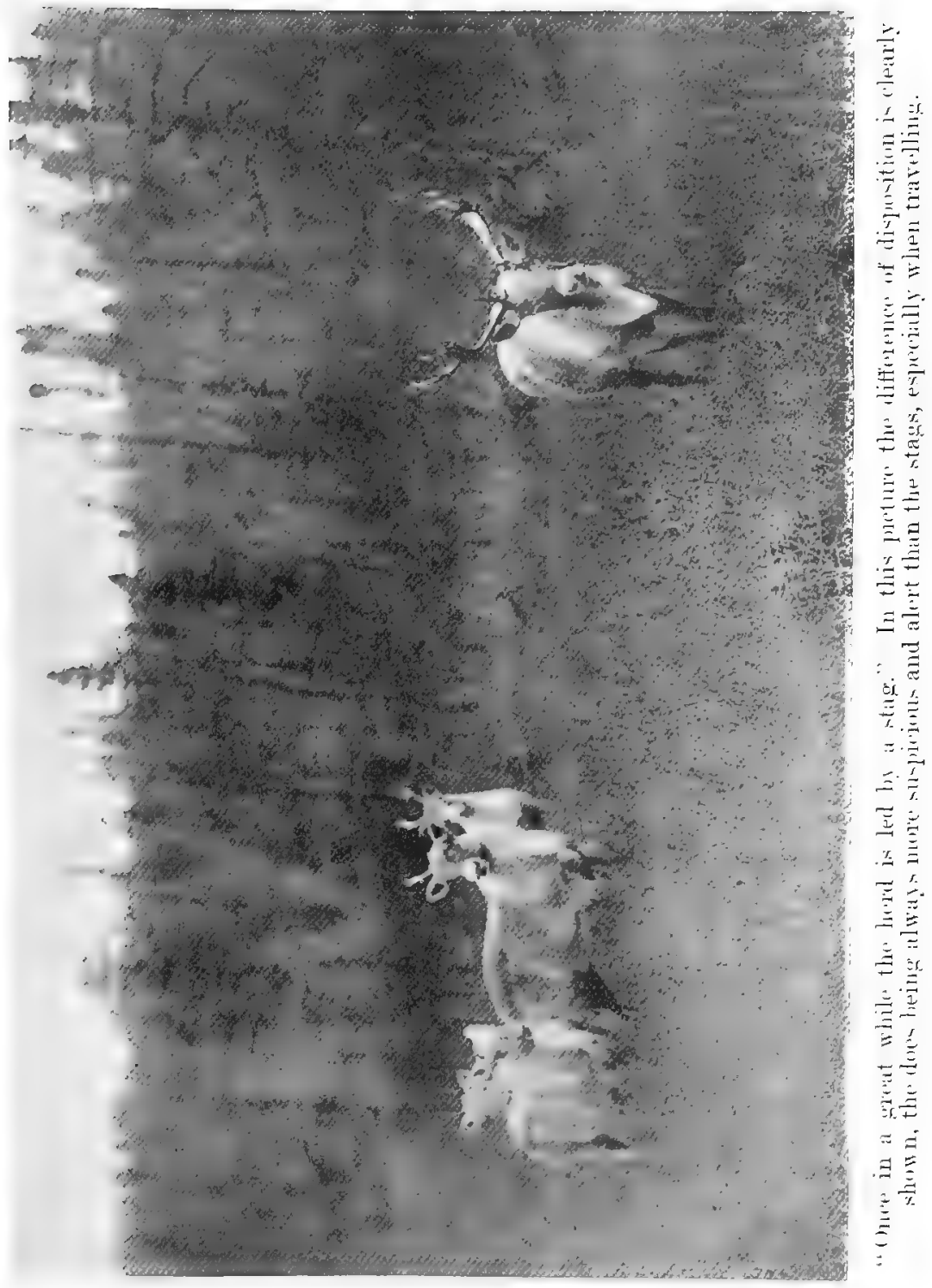



is done almost entirely by daylight, chiefly before 10 in the morning and after 3 in the afternoon; only during very bad weather, when the snow is becoming dangerously deep, or when extreme cold threatens to freeze and so close the rivers, do they move much at night. One of the sights which I live in hopes of seeing is that of the south-bound animals crashing through the frozen rivers in a driving snowstorm, for then they have no fear of man and would be easy targets for the camera. Their one idea at such times is to reach their southern destination where they can, by constant work, procure sufficient nourishment from the snow-bound country. This winter they will soon be there, for the greater part of the migration has already passed, perhaps the largest migration that has occurred for many years. Fully two thousand have passed within my sight during the two weeks that I have been on Sandy River. They have treated me well, and if the weather had only been brighter, I should have had excellent pictures to show. This is the sixth consecutive year that I have spent at least part of the southerly migration season along Sandy River in the hopes of opportunity to photograph these beautiful creatures. But hitherto luck has always been against me. 'Two years ago, I spent six long weeks watching and hoping day by day that the migration would begin, but something had gone wrong with it, and it was not until well into December that the great herds of south-bound animals came along, and by that time, of course, the stags had shed their horns. Other times I have spent two to four weeks watching 


\section{WILD LIFE AND THE CAMERA}

the leads but without success. Why, you may ask, am I so anxious to picture the Caribou, that I should devote myself year after year to the effort? Surely there are many other animals to portray with camera, brush and pen, animals, too, that are easier to find perhaps? That is, of course, true, but they are for the most part animals far better known, of which more or less truthful pictures have been made, but the Caribou of Newfoundland have scarcely been fairly pictured. Paintings of them are usually grotesque caricatures of the graceful creatures. Look at almost all the pictures that have been made, and what do you see? A lean, sad, miserable creature with ungainly legs, exaggerated knee-joints and a hang-dog expression that in no ways resemble the wild Caribou. How it comes that these animals are not more faithfully pictured is probably because the usual zoo specimens from which the studies are made are not in normal condition. They almost always suffer from a disease which changes their entire appearance; the poor creature survives but a short time in captivity, succumbing before it reaches maturity to an illness which apparently is unpreventable. Thus it is that we see so few Caribou in captivity. The change of food, probably more than the change of living, is the cause of this. But whatever it may be, we never see a captive Caribou which resembles the animal in its natural haunts. To my mind there is no more graceful, beautiful animal than the Newfoundland Caribou, beautiful in form and wonderful in colour; yet the question of individuality among these creatures must be considered. 


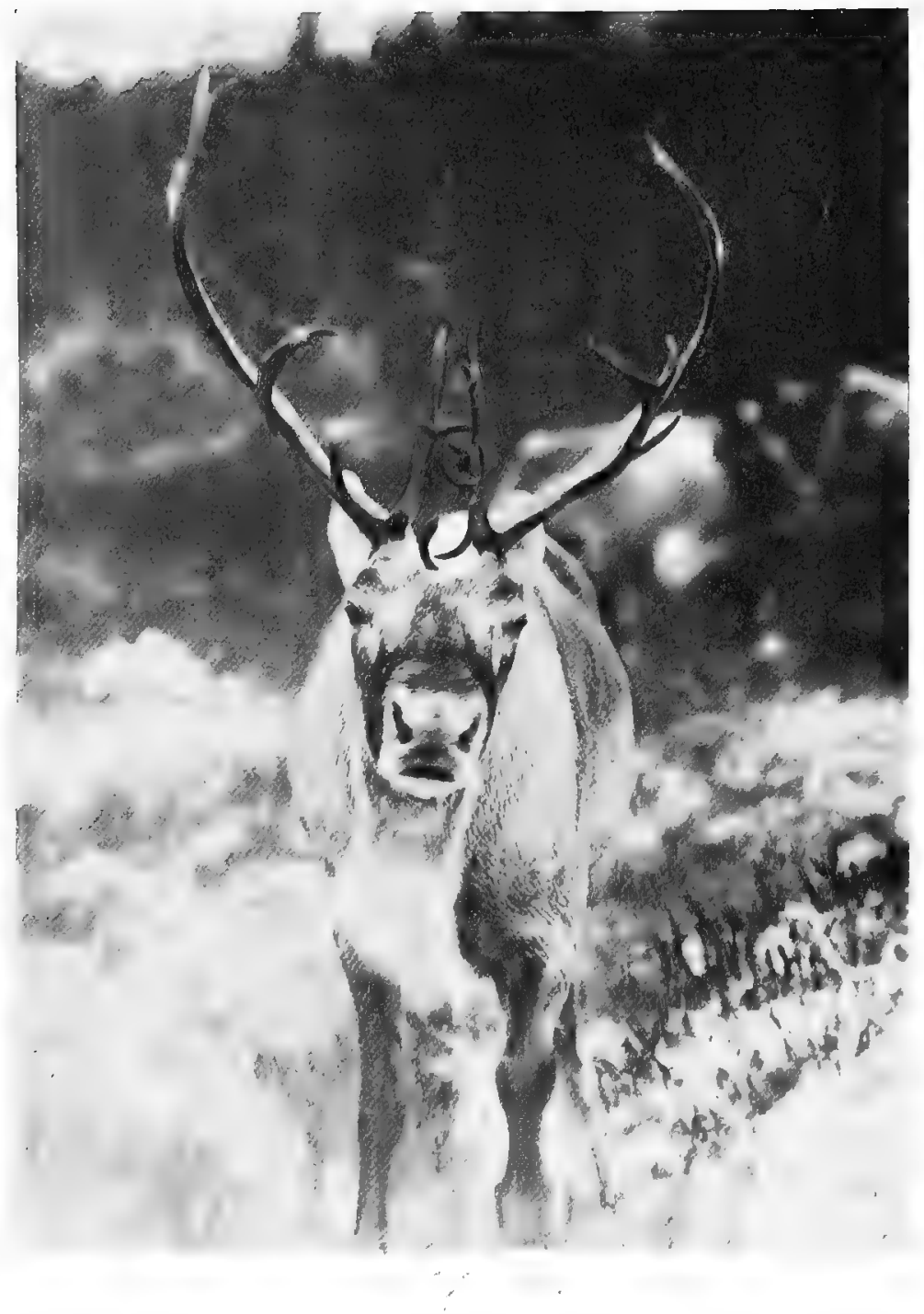

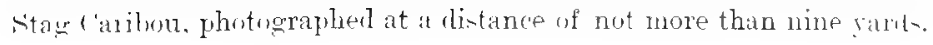



You will find magnificent stags which resemble the majestic elk ; then again there are many large stags whose ugliness and ungainliness are such that they are almost comical. So also with the does and fawns. People, as a rule, fail to realise this marked individuality in wild creatures, both as to appearance and character. Yet I believe it to be as great as, if not greater than, with the human being. The pictures which accompany this article, though they do not do justice to the originals, at least give some slight suggestion of their beauty, and I hope they will help to correct the common idea that the animals are always ungainly and unlovely. If so, I shall feel even more fully repaid than I have already been by the joy of doing the work itself. As to the pleasure of doing this work, I have no words at my command which will give any idea of it. There is in it a peculiar fascination, almost impossible to describe. A fascination and pleasure which obliterates all traces of the hardships, yes, and even sufferings with which the work is often attended. To give some sort of a reality to this work, I feel that the writing should be done on the spot, for it has been said by the wise ones that a man should be in the environment of which he is writing. Surely I am in the proper environment, even though the conditions scarcely favour writing, for while I see the pencil moving in a somewhat erratic manner over the paper, my hands are so benumbed by cold that I can feel nothing. How different from writing in an attic, where bare walls stare insolently and each step on the rickety stairs suggests the postman coming with manuscripts " returned with 
thanks!" Different, too, from a cozy studio or warm, snug library with all its comforts. Among no such limiting surroundings am I writing, but out on the bare and bleak yet beautiful barrens, where a carpet of richly-coloured mosses fights with the sombre greys for supremacy. No painted ceiling presses on my head, the great limitless, blue vault is above me, or the sun is at any rate shining with seductive warmth above the leaden-grey clouds which so persistently hide its beauty. Often the snowflakes, driven by an ill-tempered and keencutting wind, chase each other across the paper and play hide-and-seek with the pencil point. My eyes, besides being on my work, are also constantly scanning the country, for one can never tell at what minute a mighty stag or a silver-hued line of Caribou may come in sight. They seem to spring from nowhere, and almost before the camera can be pointed at them they have come and gone, leaving, perhaps, nothing more substantial than a mental picture. To have any chance of success, one must be keenly and constantly alert. Hours and even days may pass without the sign of a Caribou, but it seems as soon as one relaxes for a moment, the animals come. For this year, I must bid goodbye to these Caribou of Newfoundland. Perhaps next season we may meet again, when I may be better able to prove the beauty of the reindeer of the western world. With keen regret I roll up the tent. My only companion, the fluffy jay, sits by my side and we share our farewell meal. He knows I am going and murmurs softly as he watches me pack the canoe and start down the river. No 


\section{THE CARIBOU MIGRATION}

tangled mass of orange-coloured antlers breaks the graceful line of the canoe; my trophies, as yet invisible and of unknown quality, are packed in a tiny waterproof case, awaiting the magic touch of the chemicals which will discover whether or not my aim has been true. If true, I shall have pictures to show. If not, the many memories of the trip must suffice, and they will live and improve as the years go by. 



\section{THE STORY OF A PORCUPINE HUNT}





\section{CHAPTER III}

\section{THE STORY OF A PORCUPINE HUNT *}

How a series of photographs were made directiy from the wild animal for the purpose of illustrating a story. Probably the first time that wild animals were ever made to pose in this way before the camera.

In the month of April, 1901, a telegram from a New York publisher came to me as I was about to start off for a day's bird work: "Come in immediately, have splendid story to illustrate." The story proved to be about the Canadian porcupine-an animal I had not yet seen in its wild state. Would I undertake to make the pictures entirely with the camera, so as to give a touch of realism more convincing than if the work were done by hand? Somewhat reluctantly I promised not only to make the set, but undertook to have it completed by June 10th. Having made this rather rash promise, the next step was to find out where to look for the porcupines-without having to go too far for them. Inquiries among my naturalist friends resulted in information which was not very hopeful. The opinion was that the shortness of time would make it practically impossible.

Being blessed with a decidedly optimistic dis position, I hoped for the best, packed up an outfit of cameras and warm clothes, and started for the Adirondacks. Inquiries among the residents

* Not previously published.

W.L.C. 
of a very small village where the train dropped me one cold, rainy morning led me to hire a "rig" and drive many miles over roads which were roads in little more than name. For the long winter frost, coming out of the ground, had converted the road into a regular mire in which the wheels sank nearly to the hubs and frequently stuck in a most alarming way. Twice the decrepit harness gave way under the unusual strain. The prospects of ever reaching the little mountain farm were at times anything but promising, but by dint of much coaxing, picturesquely intermixed with a fair amount of "cussing" and a great deal of good luck, we finally drew up at a small log house of neat appearance. Now came the seemingly impossible task of making a backwoodsman understand that I wanted his help in connection with hunting for porcupines, and photographing the queer beasts so as to fit the story. This meant bringing in two characters, a man and a boy. The man proved most intelligent, and even though he regarded me for some time as a mild lunatic who might without risk be humoured in his strange whims and fancies, he promised all the help I needed. One of his sons was about the age of the boy in the story, so it only remained for us to find the most important member-the porcupine.

Now the finding of these animals is easy enough in the regions where they abound, but finding them and handling them are by no means the same. The porky has been said to have more good points than any other animal, a sad but very true joke, which can only be thoroughly appreciated by those 
who have attempted to control the creatures. It unfortunately happens that they are almost entirely nocturnal in their habits, coming out towards dusk and returning to their sleeping quarters about dawn. As the photographic work could not be done at night it was necessary for us to secure our would-be, or perhaps I should say our would-not-be models during their nightly wanderings and keep them till morning, all of which sounds easy, but was none the less the cause of many tribulations and disappointments ; for, be it remembered, a porcupine can climb almost anything and if enclosed in a box will eat his way out within a few hours. We decided a sack would be the thing, so when on the first night we caught a fine animal which was prowling about seeking what he might devour in the way of spade handles or other wooden articles used by men, we put him in a sack, tied it up, and put it in a barrel. When morning came we carried our victim to a place where the setting coincided with that of the story. The camera was carefully arranged, and the bag opened, and out rolled an animal which possessed not a single point, good or otherwise. All the quills had been transferred to the sack, and we beheld a rough, hairy and very sad-looking model utterly unsuited to our purposes. This was most unfortunate, because the picture demanded snow. And this small patch, hidden in a sheltered nook, a last remnant of the winter, was the only snow in the region. The day was warm and springlike, so that in a few hours this too would be melted and our chance gone for the year. There was nothing to be done for this day, 
so after releasing our moulted friend we returned to the farmhouse sadder and wiser men.

During the afternoon we made an enclosure which would safely contain our next victim, and when night came we went out to hunt. Before long the dogs began a furious barking; they had discovered two porkies behind the chicken house, fortunately not far from the new enclosure. With the aid of the dogs and by much pushing we managed to get the prickly creatures inside and left them there till morning. Soon after breakfast we started for the dwindling snow patch-a curious procession. One of the porcupines was slung from a pole, secured by all four legs; in this way the man and the boy carried him, while I followed armed with a camera, tripod, and other paraphernalia. All went well till we came to the river, which had to be crossed in a very small, frail, low-sided punt. The river was a raging torrent owing to the recently melted snow, and the prospects of reaching the opposite bank were not at all cheerful. Two of us got into the punt with the porky, who was very well behaved until we were nearly half way over, when a lot of water rushed over the side, soaking the poor beast, who immediately began to squirm so vigorously that he got his feet out of the slip knots, and, finding himself free, made straight for the end of the boat where the man was devoting all his attention to paddling and steering. As a very close companion a porcupine is scarcely to be recommended, especially in a small and very frail boat in very rough water. The man had on heavy boots, and with these he pushed and pushed the 
determined animal. But the more he pushed the more determined did the animal become. Finally he took the paddle and with it managed to shove the creature back; but with very nearly disastrous results, for the punt swung broadside to the yellow curling ripples, and only by good luck and prompt action were we able to avert a capsize. Finally we landed, a sadly bedraggled trio. The man's feet looked much like pincushions, so full were they of the porky's quills. It took us about an hour to drive that animal to the snow patch and another hour to persuade the obstinate bunch of quills to pose as required by the story. Finally, however, the picture was made, and as the animal had lost so many of his quills we released him as being of no further use. On returning to the farm we found that the second one, which we had imagined so securely imprisoned, had taken French leave, and we were left without a model for to-morrow. 'That night and several more we hunted in vain for another suitable porky; we found several, but all were of most disreputable appearance.

At length the man suggested that we go to some woods five or six miles away. There not only should we find an abundance of the animals we sought, but the conditions would be thoroughly satisfactory for the setting. All this sounded so hopeful that we packed up, and with blankets, cameras, and food supplies for five or six days we made an early start, each of us carrying our loads of about sixty-five pounds. It was a delightful walk through those mixed forests; at times we made our way among the dark spruces and hemlocks, walking on the soft, 


\section{WILD LIFE AND THE CAMERA}

spongy moss and climbing over the frequent windfalls. Then there would be hardwood ridges where the gleaming silver-and-white of the beeches and birches reflected all the tender tints of the delicate spring leaves and bursting buds. Many of the early arriving warblers darted among the lacelike foliage searching for unwary insects. It was all beautiful, but the hills were many and steep and the loads heavy, and, worst of all, the mosquitoes and black flies, those terrors of the otherwise perfect north-woods, were wakened to unwonted activity by the warmth of the spring sun. The edge of the lake was reached at last; here we made camp in simple fashion. No tent from the city outfitters. Itwas not needed in the land of birch-bark. In less than an hour we had peeled off great slabs of glistening bark, enough to cover our lean-to and render it proof against the most severe rains. Before the sun set we visited the lake and caught a few trout for supper. Strange it is how much one enjoys a meal cooked out of doors, where the smell of burning wood permeates everything. 'The simplest food, badly cooked though it may be, and usually is, tastes better far than the best of indoor cooking. A few rashers of bacon curled and smoked over the glowing embers, eaten with hot soda biscuits (often called scones) baked in the tin oven, is good enough for any man out in the woods, yet the same man would scorn such a dinner served on delicate china in a well-appointed dining-room. Why is it? Just as for the fisherman it is not the fish but the conditions, under which they are caught that gives the pleasure; so it is with the 
food. It is not the food itself, but the surroundings, the environment, which give it such a zest.

We rolled ourselves in our blankets on our springy beds of spruce boughs and watched the crackling fire, fascinated as one always is by the ruddy smoke as it swept upward toward the twinkling stars, faintly illuminating the dark branches of the surrounding trees. As we watched we listenedlistened for the sound of a wandering porcupine which, attracted by the smell of bacon, might be tempted to approach our camp. While watching we often dozed, for we were tired with the healthy tiredness of outdoor life. It was, perhaps, ten o'clock, the fire had died down to a few smouldering logs which sent up fitful flames of tiny sparks and blue wreaths of smoky plumes, when we were awakened by the faint, shrill call of porcupines, several of which were evidently near by. We listened for some time until we thought we knew where the nearest one was. Then, slipping on our boots and taking torches of birch-bark, we quietly made our way towards the sound. On we went, further and further, making our way with great difficulty over the fallen trees, among the upturned roots and the tangle of underbrush. Suddenly the flaring torch showed us a porky not twenty-five feet away. The light striking the polished ends of the quills gave him a most peculiar appearance. For a moment he watched us, surprised at the strange sight, then, deciding that we would look better from a greater distance, he started away with all of us after him. Never have I taken part in a stranger chase. We 
floundered in mudholes, tumbled over tree trunks, caught our feet in the hidden moss-covered roots as we tried to dodge this way and that after the elusive creature who seemed not to know which way to go. First this way, then that way, sometimes with a sudden change of mind back he would head, dodging right between us, just as we were mixed up in various obstructions in the strange light cast by the three torches, our dancing shadows chasing each other like dark phantoms. On and on we went, paying no attention to our direction, till at last we cornered the bewildered beast between the root knees of a large cedar. With considerable difficulty we fastened a stout line around one hind leg of the indignant creature, and with still greater difficulty drove him to where we thought the camp should be. Apparently we had been going in circles while stumbling through the woods, and though not more than a few hundred yards from the starting-point, we were so bewildered that none of us could say where the camp was. Finally, after many false directions and signs had been followed, we were surprised by a thin column of smoke and sparks rising only a few yards away from where we were holding a consultation. Had it not been for that smoke we might have wandered till daylight.

On arriving at the camp we were much surprised and amused to see a fine big porcupine hurrying away. The rascal had been stealing our bacon and we came in time to save only a small part of it. Hastily securing our captive to a tree stump, we proceeded to catch the retreating thief. Soon we had him tied by the hind legs to a convenient tree, 


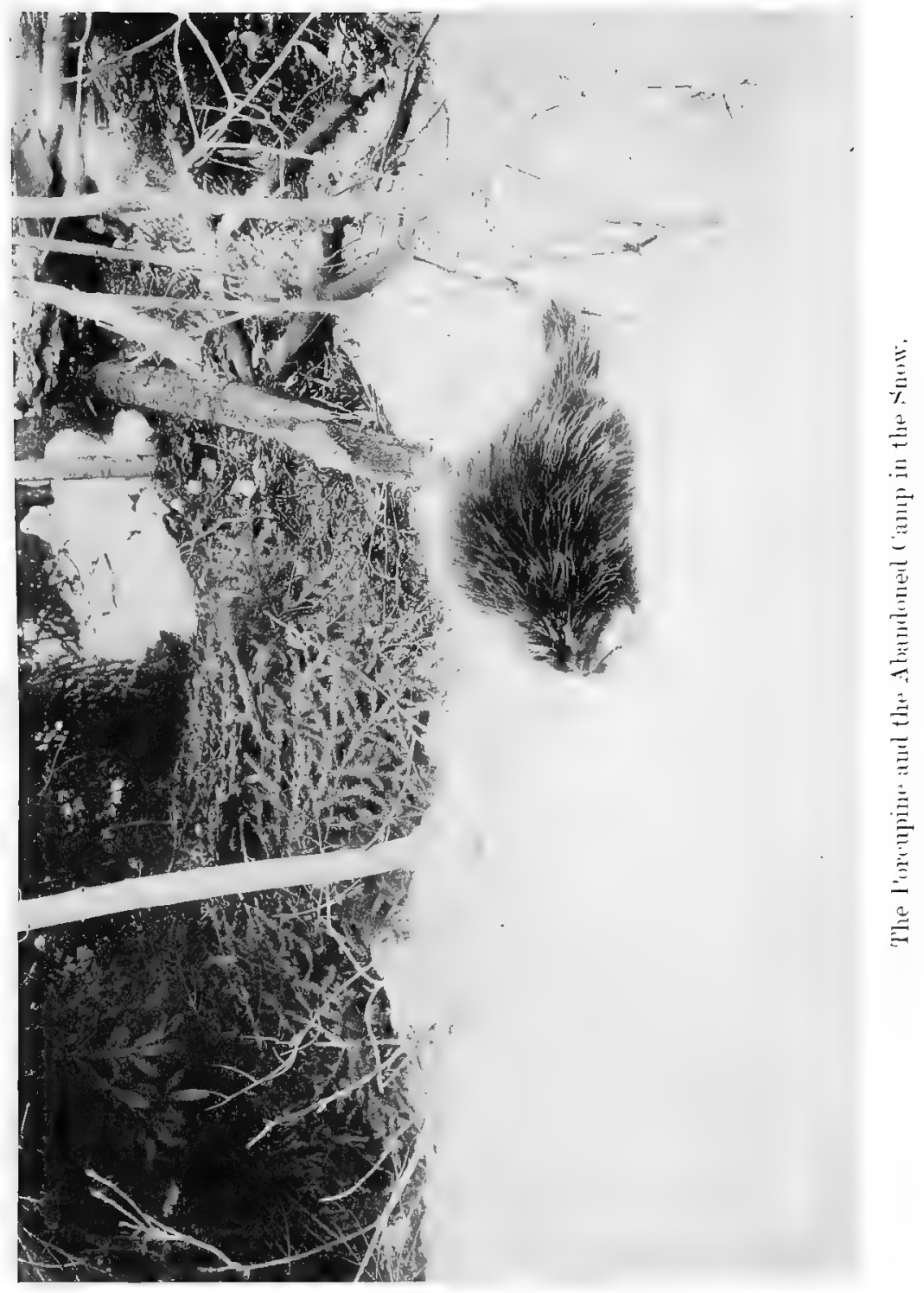



and we returned to the camp to secure more thoroughly the first-caught porky. To our utter disappointment we discovered nothing but the end of the cord, which he had evidently bitten through. It is scarcely necessary to say that we were utterly disgusted at our bad luck, or carelessness, whichever you like to call it. We had learned our lesson however, and immediately took precautions against the escape of our last victim. Then we all crawled into the lean-to for a few hours' sleep. The night was warm, so we had allowed the fire to die down, and we arranged our blankets in the dark. A shout of surprise and pain from the man caused me to quickly strike a match and by its flickering light I saw a most amusing sight. The escaped porcupine had retreated to the inner part of the lean-to, and finding the blankets very much to his liking, had decided to make his bed there and then. The man in moving the blankets had come into contact with the animated pincushion and had received a full dose of quills into his hands, with the result that he entirely failed to see the funny side of the situation. Of course he was powerless to do anything with his fingers in that condition, so after lighting a torch I extracted all the quills, a painful and very tedious task. The boy in the meantime kept his eye on the porky. Eventually all the quills were removed, and then the porky was fastened to a tree to await the morning's work.

After a few hours of refreshing sleep we were up, and by the time the sun was high enough we began the photographic work. One of the pictures called for a lake shore setting; this required my 


\section{8}

\section{WILD LIFE AND THE CAMERA}

going into the ice-cold water with the camera, and a more miserable half-hour I have seldom spent, for apart from the cold, and the water was well above my knees, the air was filled with thousands of detestable black flies and "no-see-ems," whose poisonous stinging bite nearly drives a man crazy. It was no fun, but really hard work, and I could not help thinking that sitting in a comfortable studio making drawings was far easier than making photographic illustrations of wild animals.

One of the subjects was a porcupine sitting among the topmost branches of a hemlock tree. How I blessed the author of the story for choosing such a tree with its bending branches. We cut down a vigorous-looking tree, took off the top and stuck it firmly in the ground. The next question was, how could we induce the porky to climb it? Apparently there was no question about it so far as the animal was concerned, he simply refused point blank, and nothing that we could do had the slightest effect on his determination. With any other small creature it would have been an easy matter to place him exactly where we wished, but unfortunately one cannot handle these prickly customers. Finally we tied the perverse beast to a stout pole, hoisted him up, and when he grasped the branch we cut the cord, whereupon he promptly fell to the ground, and we had to repeat this operation several times before he at last decided to hold on and the picture was quickly made.

Another illustration required a dug-out canoe. The man said he knew where there used to be an old one, which we might be able to find in a certain 


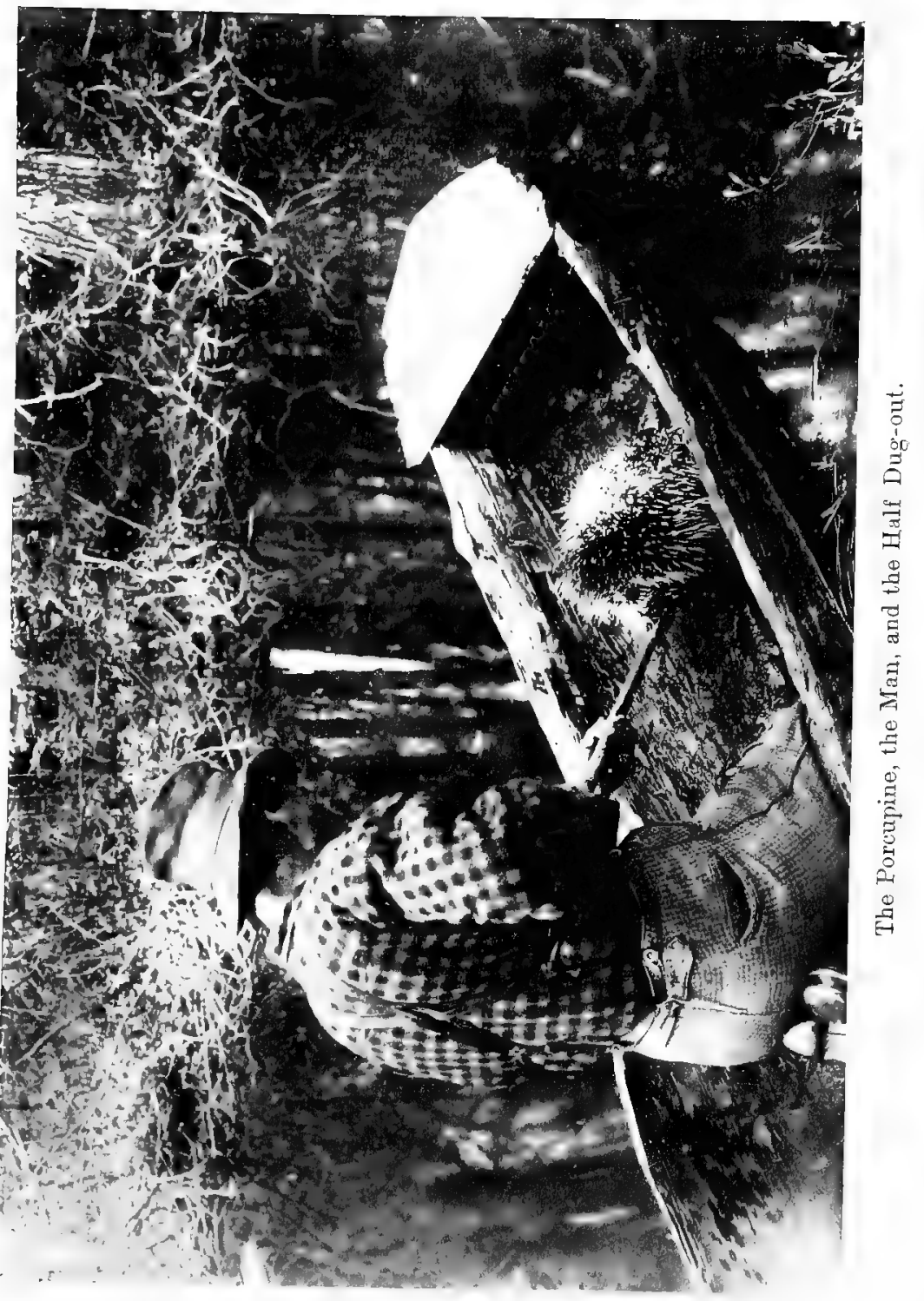



tangled swamp. On our way to the place we found a fine porky sitting asleep on the branch of a tall spruce. Surely an excellent opportunity for securing a model with very little trouble. Simply cut down the tree and we would have him, so thought we. Porky thought differently, As we cut, up he went till he reached the topmost branches. The tree swung slowly as the last strokes of the axe cut through, then with gradually increasing speed it heeled over, grazing another tree as it fell. The porky took advantage of the situation to scramble off the fallen tree on to the standing one, and there he stayed, smiling, I imagine, at our discomfiture. To cut down the second tree was the work of only a few minutes, and we began, but before half a dozen white chips had flown from the keen edge of the axe the clever creature decided that it was moving time, and he left the vibrating tree and climbed into the branches of another one. The pursuit was hopeless, so we gave up and continued our search for the dug-out, which we eventually discovered in a long abandoned beaver canal leading from the swamp to the lake. When I say we found the dug-out, I should more properly say we found half of it, for that was all that remained of the rough-hewn craft. Of course itwould not float; we therefore placed it in very shallow water so that it rested on the bottom, with the broken end on a tussock, and when we brought the necessary porcupine the following morning we were able, with very slight trouble, to make the picture just as it was described in the story. The camera was placed so that the broken 
part of the canoe came against the edge of the plate. We had many other interesting and sometimes tiring experiences before the series of pictures was completed, and it was with great pleasure that I sent in the result two days ahead of the appointed time.

This was probably the first animal story ever illustrated entirely with the camera in which a really wild or, I should say, many wild animals were used and every detail of the described scenes rendered as accurately as though done with the brush. Whether the results justify the labour is a question. Apart from the fact that they give a touch of realism and so make the story appear more true, I should be inclined to answer it in the negative. Such pictures are not easy to procure, but there is in the making of them an element of sport which is a reward for all of the hardships, and further than that it takes one into the woods where there is unlimited opportunity to learn something of the great out of doors, where Nature has always something new to tell us if we will but use our ears and our eyes. And when at the end of each day's work in the woods we roll ourselves up in our blankets, we sleep-sleep that delicious refreshing sleep of the kind unknown to the man who works only in the studio. 


\section{BIRDS AND THE CAMERA}


. 


\section{CHAPTER IV}

BIRDS AND THE CAMERA

Nowadays, when the camera forms a necessary part of the nature-interviewer's and pleasure-seeker's outfit, no creature, human or otherwise, is safe from the press-the-button brigade. Nearly every person who can afford one, and many who cannot, possess or hope to possess a camera, and with these every imaginable object, animate or inanimate, is portrayed. Comparatively few, however, of the great army ever direct their energies to the photographing of birds. It is difficult to account for this lack of interest in such a fascinating branch of camera work; perhaps it is because so few people know or care for the feathered tribes, while even those who really do interest themselves in these useful members of creation fear the many difficulties to be met with in bird photography. Not many people are possessed of a sufficient amount of patience to watch quietly through the long hot hours of a summer's day in the hopes of perhaps securing a single photograph of a live bird. Without this patience no one need hope to succeed. True, an occasional "snapshot" when conditions happen to be favourable may, and sometimes does, result in the obtaining of a good picture, but he who would interview a bird with the camera must be prepared for endless disappointments; and, should weeks 


\section{WILD LIFE AND THE CAMERA}

pass by and no good photographs be secured, he must not be discouraged. Birds are somewhat uncertain in their moods, and years of persecution by man have had the effect of instilling in them a very natural feeling of fear and distrust, which can only be changed by kindness and patience.

My chapter on the worm-eating warbler and her family offers a good example of what patience and fair treatment can accomplish with birds. It must not be imagined that this comparatively rare bird would come so near the camera when first we met; that would have been expecting too much. Only after she-for I presume it was a female-had learned to know me, and realised that I intended no harm, did she place such confidence in one whom she had probably considered her natural enemy. Let one of these warblers be seen by a collector, and what is its fate? Death, with Science as the threadbare and usually valueless excuse. Would that more of the so-called collectors (I do not refer to those who are really working upon a scientific basis and with a knowledge of their subject that enables them to do the good expected of them) might more often exchange the gun for the camera! If that could be, photographers as well as the birds would be the gainers, so that from a selfish standpoint, if for no other reason, I would recommend the harmless camera. Take for example the accompanying pictures of a family of young crested flycatchers. Surely theyare more likely to give pleasure in this form than if they were a set of the most perfectly made "skins," arranged with infinite care 


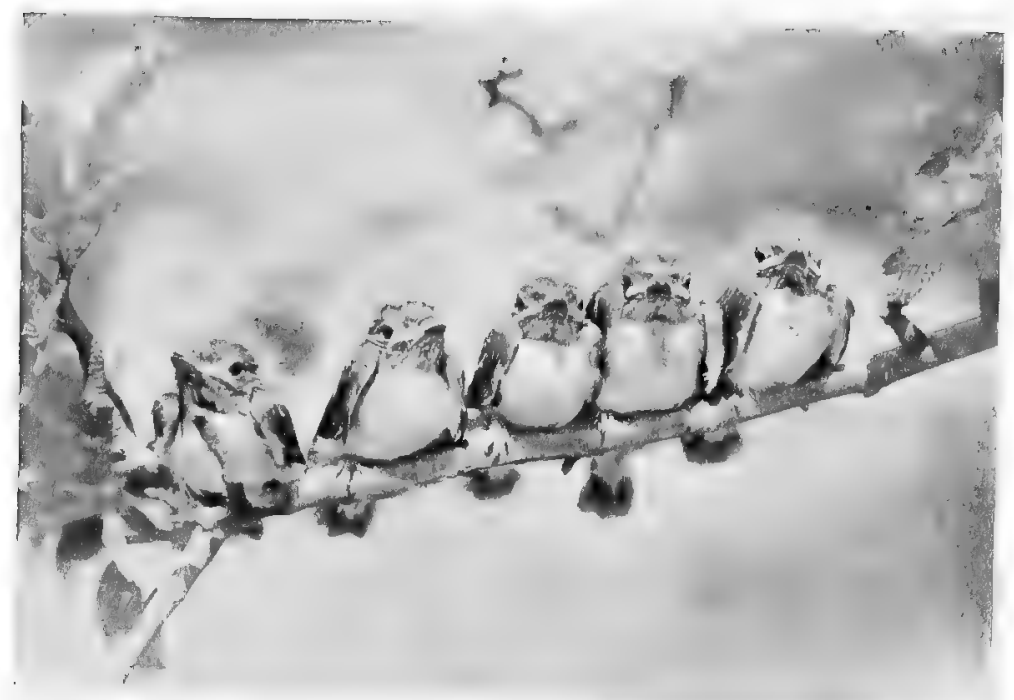

The Umuly Broud of Flycatcher'.

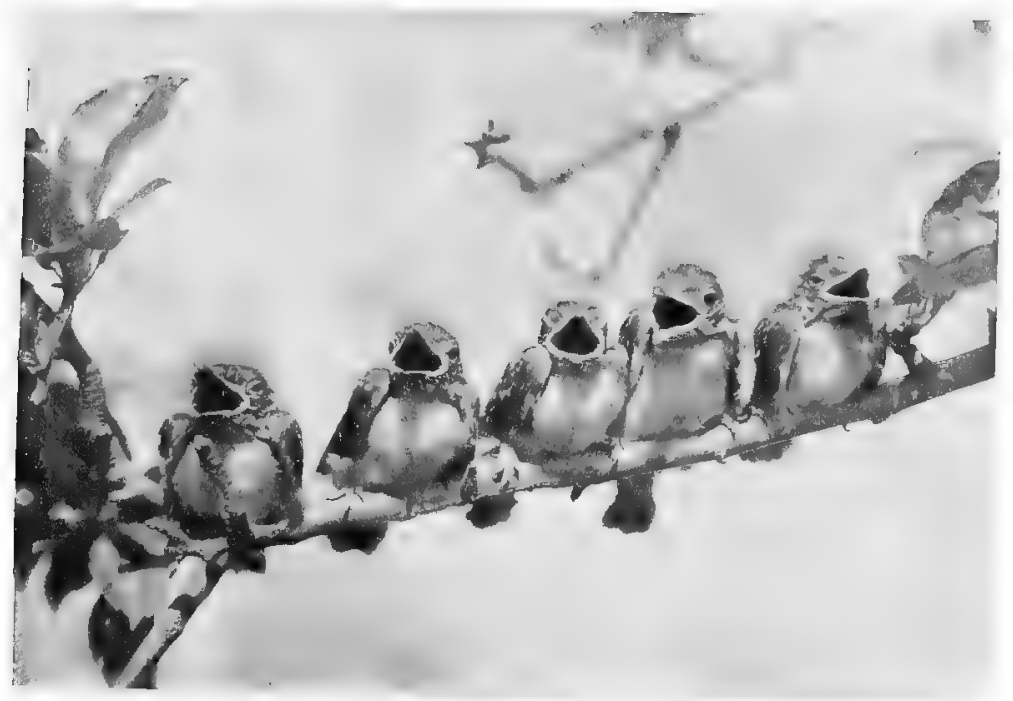

The same linood realy for Fond. 

in a fancy cabinet. 'These fly-catchers I had watched ever since their arrival into the world. Their nursery, so carefully made, was placed inside the dead branch of an old apple tree. With full consideration for the comfort of the prospective family of six, the parents had gathered a quantity of pine needles, and of these entirely was the actual nest made; a few feathers were added as a lining that would keep the nestlings warm in their earliest babyhood.

During the first few days of their lives the youngsters were by no means objects of beauty; rather were they grotesque, with their large heads and small pinkish bodies, loosely covered with wrinkled skin, and entirely innocent of feathers or any other covering whatever. Watching their extremely rapid growth, I decided that by July 4th some, if not all of them, would be nearly ready to be launched out into the great world of many enemies; so it was on that day the family posed for me.

It usually happens that in a brood of birds there is a weakling, so I was not surprised to find upon close examination that one of these fly-catchers was smaller than he really should have been; and not only was small, but much undeveloped. While the others were almost able to fly, he could not even keep his balance, so for that reason I was unable to place him on the apple branch that formed the perch for his brothers and sisters. They were strong and well developed, but of unmanageable dispositions. Though perfectly able to sit on the branch, it was a long while before I could induce them to do so. W.L.C. 
One in particular aggravated me beyond words. Instead of using his feet for what nature intended them, he insisted on clutching tightly hold of his wings, as though that were of the slightest use. If I disengaged the unruly members and placed his toes as they should be-around the branch-he would roll off, either backward or forward, exactly as a mounted bird would do if the leg wires were not secured. For fully fifteen minutes this performance was kept up, varied only in its tiresome monotony by the other four nestlings. Every little while they would simultaneously follow the bad example of the little scamp-who, by the way, was about the largest and strongest of the brood-and with one accord, as though they had been released from their support by the pressing of an electric button, they would all drop off.

It is quite probable that most people who were so unfortunate as to have been anywhere in the vicinity of New York will remember with unpleasant distinctness the heat of the national holiday-July 4th, 1900. In the apple orchard where the fly-catchers had their nest, and which was in a hollow entirely surrounded by hills, the heat was intense, for the breezes did not venture near. On the higher ground the trees might be seen lazily waving their topmost branches, as though wishing to inform the world of the fact that up there, at least, the soft summer winds deigned to live; and I devoutly wished my friends the flycatchers had not chosen for their nestling place this orchard, which seemed as though it had been transplanted from the tropics. 
With the perspiration dripping from every pore, and the horse-flies trying persistently to make their dinner off my neck, is it to be wondered at that my stock of patience was soon nearly exhausted? Yet there was something decidedly amusing in the behaviour of my little models, their peculiar objection to the business of posing and the aggravating manner in which they expressed their disapproval of the whole proceeding. Many times I would succeed in putting three or even four on. And then, just as I was picking up the last of the unruly crew, the first and then the second would fall limply to the ground. When these were restored to their perch the others would drop off one by one. It really was quite enough to try the patience of a saint. Suddenly, and with no apparent reason, the young rascals became possessed of a better spirit, and sat as quiet as models should. I was greatly relieved at this welcome change, but how was it to be accounted for? Apparently the conditions had not altered, so I was forced to believe that a note, which one of the parents had just uttered, was a command to the young; perhaps he had discovered that I meant no harm, and therefore wished his children to behave themselves. Whatever was the cause I was thankful for it, and immediately arranged the camera, so that in a few minutes all the Masters and Misses Flycatcher were secured by the dry plate ready to be handed down to, we hope, an admiring posterity.

No sooner had I made the exposure, than Mrs. Fly-catcher arrived; till then she had not shown very much anxiety for her youngsters, but now she appeared with some kind of insect in her capacious 


\section{WILD LIFE AND THE CAMERA}

beak, and with a peculiar note she conveyed to the little ones the news that there was food near by.

It is quite in accordance with the rules and regulations of bird life that when food is brought to the nest, each member of the hungry (and to be a young bird is to be hungry) family shall open his or her beak to its greatest extent. When there are six such mouths open, and each head, held on high, trembles violently in pleasurable anticipation of the hoped-for morsel, we cannot help wondering how by any possibility the parent bird can decide which shall have the food. She appears, however, to waste no time in considering the difficult problem, but instantly drops the insect, or whatever it may be, into one of the many mouths. Then, after remaining for a few seconds to see that the nursery is as clean as it should be, she hurries away in quest of a further supply of food.

Now the five young birds before me understood full well the significance of their mother's call, and one after another they opened their mouths, but in a half-hearted way that was most ridiculous. Evidently they realised the fact that things were not quite as they should have been, and that perhaps, after all, they were not going to be fed. At any rate it was better to be fully prepared, and so it was that, as each one sat with a silly expression on his face and his beak partly open, I made the picture of which the accompanying is a reproduction. After taking another photograph, showing the entire brood on the stump that contained their cozy home, I left them in possession of the orchard, and sought for myself a place where the breezes 


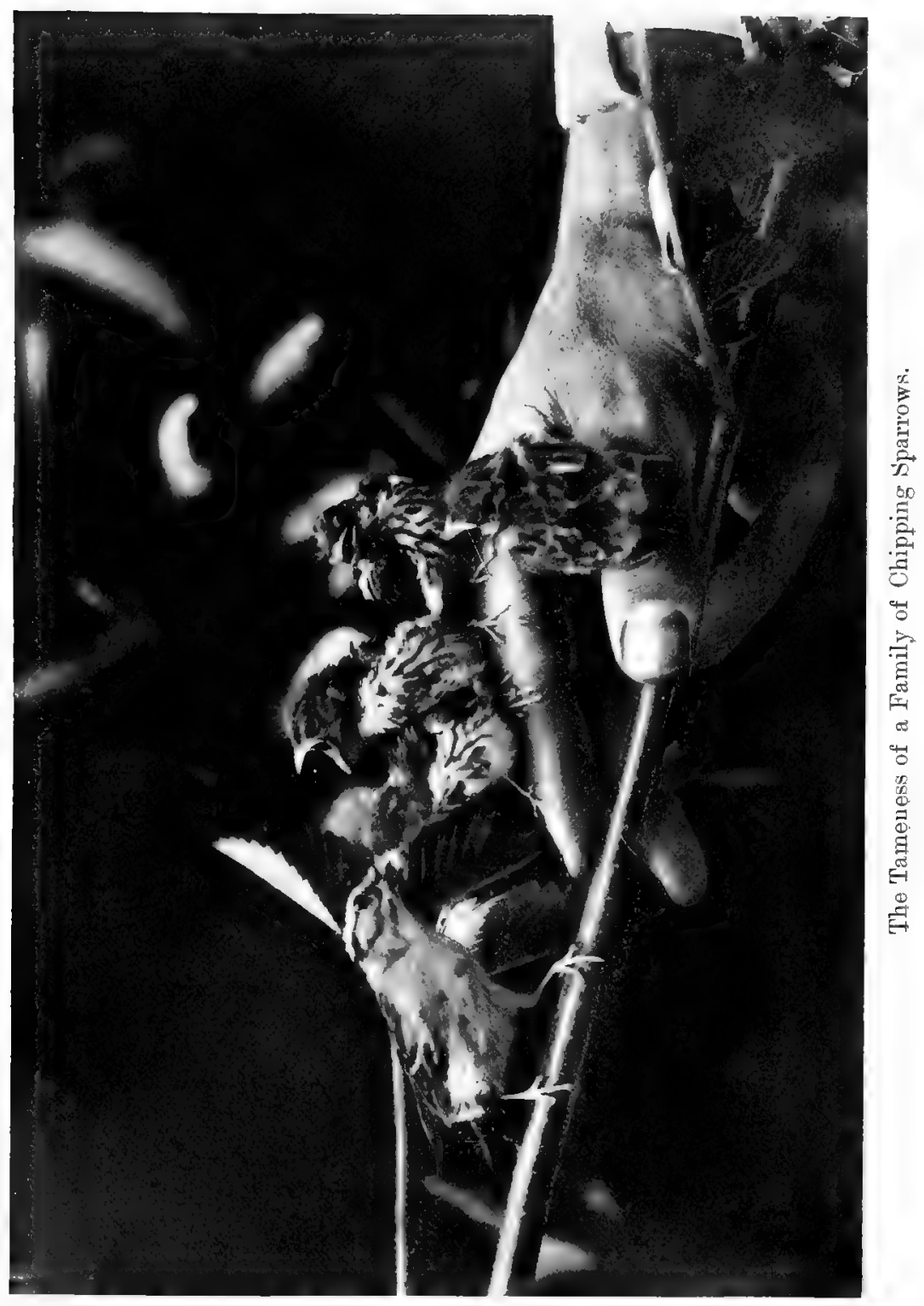





\section{BIRDS AND THE CAMERA}

blew, there to rest from the arduous, though interesting, labour of photographing recalcitrant fly-catchers under the direct rays of the hot July sun.

On such a trying day the open fields and scrub lands offered but slight inducement for bird hunting, and so I chose by preference the woods and thickets that bordered the stream.

It was a likely place for birds, but the heat was great, and I wandered in that aimless way which seldom leads to finding anything. Here and there beneath the kindly shadow of a heavily foliaged tree I noticed birds, but they showed little animation, and sat quietly with beaks open as though gasping for breath. Birds suffer greatly from heat, so that on days when the temperature is high they move about but little, excepting during the earlier and later hours of the day, preferring rather some secluded and shady place where they may rest undisturbed during the hours of the greatest heat.

Not finding anything new, I remembered the beautiful basket-like nest of the Red-eyed Vireo, in which, but twelve days ago, I had seen two eggs and two tiny naked bodies that had so recently left the cramped quarters of their imprisoning shell. Probably by now they would have abandoned their nest and be hiding in the dense tangle of vines that grew beneath the hanging cradle. It would be difficult to find them, but fortune is often kind, and I would try her once more.

The nest as I drew near bore the semblance of a deserted house, and indeed it proved to be empty, but even in its emptiness it was an object of interest. I noticed for the first time that it was 


\section{0

largely composed of strips of the paper hornet's nest. These were held in place by numerous threads of caterpillar silk and decorated with tufts of white material, probably cocoons' or spiders' nests. The entire structure was wonderfully fashioned and was a good example of the extraordinary skill of the little architects. While I was examining all these exquisite details, my attention was attracted by a bird-like sound in the thicket near by. Was it the note of a young bird? I waited anxiously for a repetition of the sound. For a few minutes all was quiet, only a wood-thrush sang its rich, sad song, and in the distance a woodpecker tapped the trunk of a dead tree. Then another sound came from the undergrowth, only the faint peep-peep of a young bird, but it delighted me, for on a careful approach, among the leaves I discovered, sitting there on the lower branch of the silky cornel, one of the most beautiful young birds I have ever met, fit indeed to have been cradled in the marvellous nest $I$ had been admiring, for it was a young Red-eyed Vireo-twelve days old-the age when its beauty is more conspicuous than at any other period of its life.

There was no gaudy colouring to this little ball of fluff that it did not need. Nothing could enhance the beauty of this softly coloured bird; almost might it be called a living symphony in grey, for the breast was very pale grey, pearly in its extreme delicacy; the head was of various shades of soft grey, while the back was of a delicate grey or olive-green that harmonised most perfectly with the other subtle shades. 


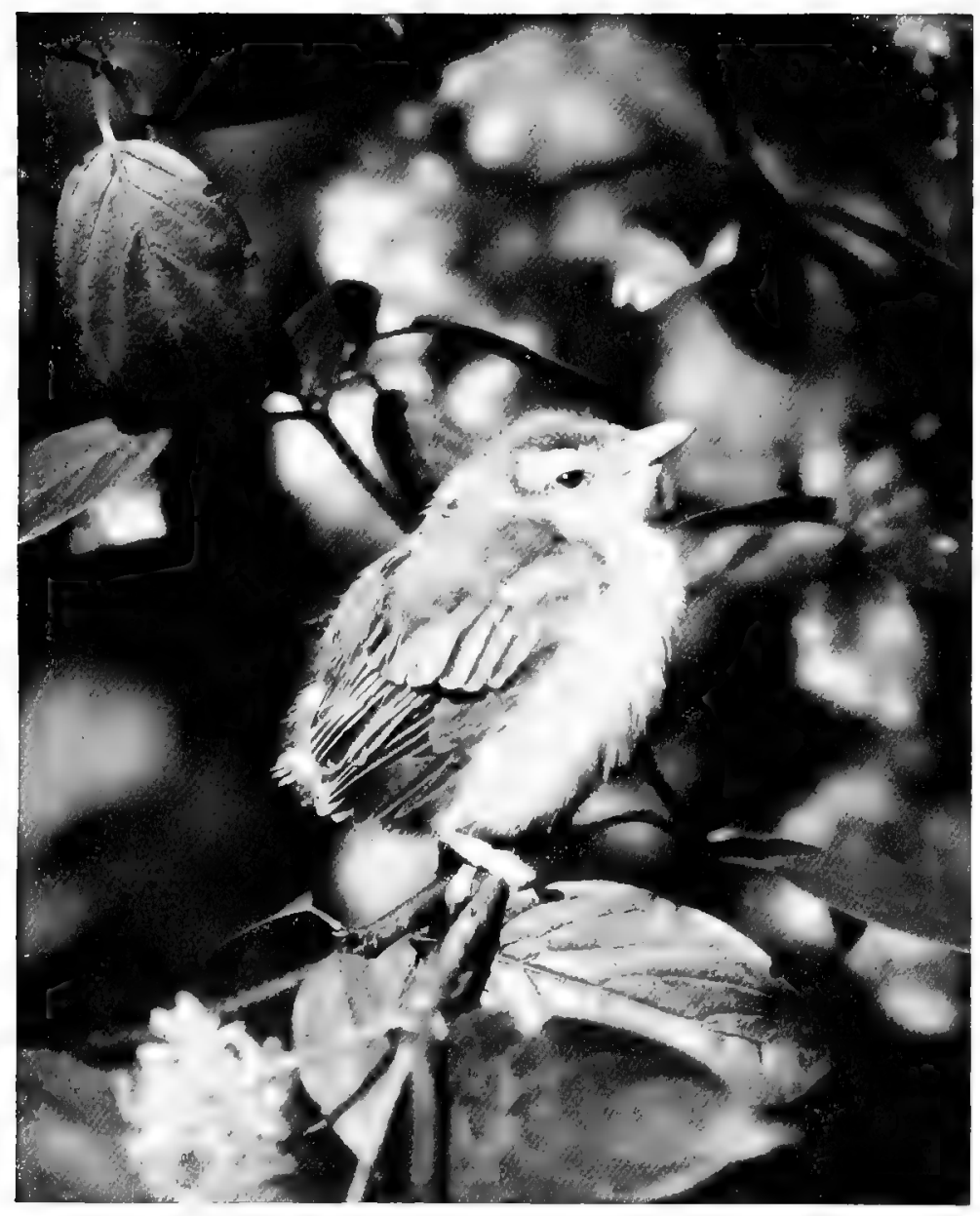

Young Red-eyed Vireo. 


\section{BIRDS AND THE CAMERA}

As a rule, when young birds are discovered shortly after they have left the nest, they first of all sit absolutely still with beak pointed upwards, and think themselves unseen. As soon, however, as they know they have been detected, they drop down among the leaves and undergrowth and are instantly lost to view. My little friend followed no such line of action. The moment I placed my finger near him, he hopped on to it in a most confiding manner. He seemed quite tame and rather tired, and I imagined he had been having his first lesson in flying and was therefore exhausted. Whatever may have been the cause I know not, but it was not very long before he nestled himself down, and gradually closing his eyes, went fast asleep, quite regardless of his strange perch. In this way he remained until a call from one of his parents awakened him; he carefully stretched his small self and then looked about him, with an expression of "Where am I ?"

Fearing lest he should become too lively, I replaced him on his natural perch and made ready the camera. His wakefulness was, however, only temporary, and before I had made a third exposure he was fast asleep again. So I left the sleeping atom to be watched over by those who, for but a few short weeks, would be his instructors and guardians, and went to pay a visit to an ovenbird whose beautiful dome-shaped nest was hidden among the dead leaves in the woods near by. She was at home when I called, so I decided to photograph her. Unfortunately the roof of the arched nest cut off the light so that under existing circumstances a 


\section{WILD LIFE ANI THE CAMERA}

good picture could scarcely be hoped for. A small looking-glass, however, served to alter things, by throwing the sunlight into the nest, so that only a very short exposure was necessary.

My mind was fully made up to make the further acquaintance of this little thrush-like warbler after the arrival of her brood, for it is only then that one can really get to know a bird. The day arrived, and the four little trembling pink bodies had taken the place of the speckled eggs. They were too small to photograph then, so I left them for two days and then made one photograph, thinking that later on, as they grew stronger, I should be able to photograph them at different stages of their growth. But this was not to be. As I approached the domed nursery I was greeted by the pitiful complaining note of the pair of ovenbirds. This was not the way in which they usually greeted me. I feared the worst, and my fears were realised. In place of the nest there was only a tangled and shattered heap of weed stems and dry leaves-the materials that but a few hours before had constituted a beautiful example of bird architecture. In the soft earth, within thirty inches of the ruins, was the print of a cat's foot. Sick at heart, I left the scene of misery and desolation, vowing an awful vengeance against cats in general. 
"BLUEY" 



\section{CHAPTER V}

"BLUEY": * A TRUE STORY OF THE VERY BEST PET BIRD

The scene was laid in an abandoned apple orchard, situated in a snug little valley, surrounded on all but the southern side by heavily timbered hills; these kept constant guard, ever ready to check the advance of the cold north wind, that enemy of the spring vegetation. Here it was that the sun's rays were held captive during the many hours of the steadily lengthening days, so that birds flocked in great numbers, in quest of the many insects that were brought to life by the generous warmth ; here also the first buds were to be found. They peeped out as though frightened, and the birds took advantage of these delicacies and ate liberally of the supply so easily procured.

With one exception all the birds were spending the long, bright days (many celebrating their return from Southern quarters) in flying about, singing, and enjoying the Heaven-sent sunshine of springthe power that was coaxing the leaves from their protecting sheaths, to clothe the woods once more in a rich green covering, the covering that must protect the more delicate flowers from the scorching heat of the midsummer sun.

All nature seemed to be rejoicing in the death of

* Never published before. 


\section{WILD LIFE AND THE CAMERA}

winter with its hard, relentless fury, that had smitten the woods and hedgerows as though with a poison breath, and bared all trees save the sturdy evergreens, alone able to withstand its furious onslaught without striking their colours.

It was the middle of April. Here and there in the woods, where the sun's rays had not yet penetrated, might be iound small patches of snow, the gravestones of the departed winter; near these the bloodroot, white as though born of the melting snow, lifted its leaf-encircled stem, and the Dutchman's breeches, with its lace-like leaf and rows of queer little nodding flowers, sprang from the rich, leafy mould. These, with the many tinted hepatica, whose hardy leaves withstand the coldest winter, were the harbingers of spring, sharing together the honour of announcing to other plants that 'twas time to rise and make ready, for the season was advancing, and the country must be decorated for the coming gala months so near at hand.

Among the birds who came to the old apple orchard so sheltered from the wintry fierceness of the north winds that insects batched out earliest here and the buds first opened and offered delicious morsels to the Bluebirds, were the many visitors who would tarry but a few short days before once more resuming the journey to their northern breeding grounds. From these they would return in a few months, accompanied by one or more broods of fully grown youngsters all joining in the great procession that would later on be journeying southward-when the nights began to be cold, and the trees (by changing their dress from green to colours that 
in their brilliancy and variety would outrival the tints of the setting sun) began to give warning that autumn had come, and cold weather might soon be expected.

While many of the birds, as we have already noticed, were only visitors, by far the greater number were old friends that had come once more to build their nests, rear their young, and fill the woodlands with song. What would the woods be without the soft melody of the feathered choristers? The early morning and the evening, too, would be robbed of their greatest charm.

Notwithstanding all the attractions offered by nature in such profusion, at this, her happiest season, Mrs. Bluebird, who had taken up her quarters in a soft nest of grass snugly arranged in a dark warm cavity in the dead branch of an apple tree, now sat there true to her trust day after day, imparting her life-impelling warmth to her five pale green treasures, smooth and round and more precious than the richest jewels. For nearly two long weeks sat this expectant mother, a model of patience and constancy, never for a moment leaving her charge except when it became necessary to satisfy her hunger. No less constant was her mate, who kept his watch near by and sang soft love songs to his patient little wife. He too was awaiting the time when the longed-for young would emerge from their shells. The great day came at last, the day of days. The soft winds of spring murmured as they carried the sweet perfume of the early flowers through the orchard. Mrs. Bluebird felt a delicate trembling sensation beneath her feathered breast, 


\section{WILD LIFE AND THE CAMERA}

an egg moved, a tiny atom had outgrown its confining shell, its bill already protruded when the mother glanced among the feathers to see that all was progressing favourably. Who shall say what were her sensations when she saw that first sign of life, the reward of her long vigil to which she had been so untiringly faithful? Can we ask whether she realised what was happening, this great mystery of life which was being enacted in that branch of the apple tree? Did she take it all as a matter of course, just an episode in the day's work? Perbaps so, but it was none the less important to the new mother. Should you doubt this statement, call to mind, if you can, seeing a bird interrupted at this crisis, what anguish is displayed, actually heartrending in its pitiful intensity, and doubt if you will whether or not there is an appreciation of the overwhelming importance of this family event. Even after the young are partly grown the parents have their welfare so deeply at heart that they will risk, yes, and even court disaster to themselves rather than allow any harm to befall the precious youngsters. What is more pathetic than the bird that pretends to be disabled in order to coax the intruder to follow her, that her young may have time and opportunity to hide themselves. With seemingly broken wings or broken legs dragging painfully behind her she flutters along a few yards ahead of the pursuer, until in some unknown way she is assured that her young are in safety. Then what a change! Off she flies and is soon lost to view. All of this demonstrates how seriously birds regard the responsibilities of parentage. Let 
us peep into the Bluebirds' nest as one by one the eggs open.

For many days these tiny creatures will have but two ideas, eating and sleeping. These to them represent life, and they respond with wonderful rapidity to their inspiration. Now that the hatching has come at last, great indeed is the excitement while the industrious parents keep up a steady search for insects with which to feed their ever hungry brood. With the first light of day they are out, searching diligently for the early insects in the dew-laden grass, and not until long after the sun has disappeared behind the western hill do the hungry youngsters stop crying for food.

At first the fledglings were anything but beautiful-small, fat, shapeless, naked bodies with long slender necks, and heads so much too large, and with closed eyes that but added to their grotesque appearance. At the slightest sound all their heads would be instantly elevated, and with sundry squeaks their mouths would open so wide that it looked as if they could swallow themselves. If no food was forthcoming, the heads, after swaying unsteadily for a few moments, would one by one drop, and once more form part of that hot, heaving, shapeless mass. Rapidly these youngsters grew, assuming shape and gathering strength; feathers, too, began to appear, and by the time they were a few days old their eyes were open, and the naked bodies were partly clothed. It does not take long for young birds to attain their full size; each day makes a difference in their appearance that must be seen to be realised. What pleasure must the change 
have given to Mrs. Bluebird! How proud of her family must she have been! That is, if we can judge the bird's point of view from what our own would be under similar conditions. Perhaps to do so is entirely wrong. And yet, after close study of birds and animals one is forced to realise that the difference between theirs and human characteristics is not so great as many would suppose. For, jealousy, individual likes and dislikes, selfishness, generosity, the sense of common responsibility-all of these are to be found in even the smallest of birds.

It was on the fourteenth day that two of the brood, being somewhat stronger and larger than their companions, climbed to the entrance of the nest and took a general survey of the surroundings. What thoughts were theirs as they saw for the first time the beauty of the great world! They balanced themselves with considerable uncertainty, standing with much of their weight on the tarsus (heel), for their feet were still very weak, but owing to the extreme sharpness of their toe-nails, they were able to hold securely to the rough bark.

It was at this time that we came into the story. While strolling through the orchard in search of material for bird photographs and study, we saw the two young birds at the entrance of their nest. Here was the chance I had been looking for-a young Bluebird that could be pictured periodically to show its growth and development. The fact was very evident that if we wanted one of this brood for a pet, and an object for study, there was no time to lose, for within a few hours they would all be leaving the nest; accordingly we selected one 


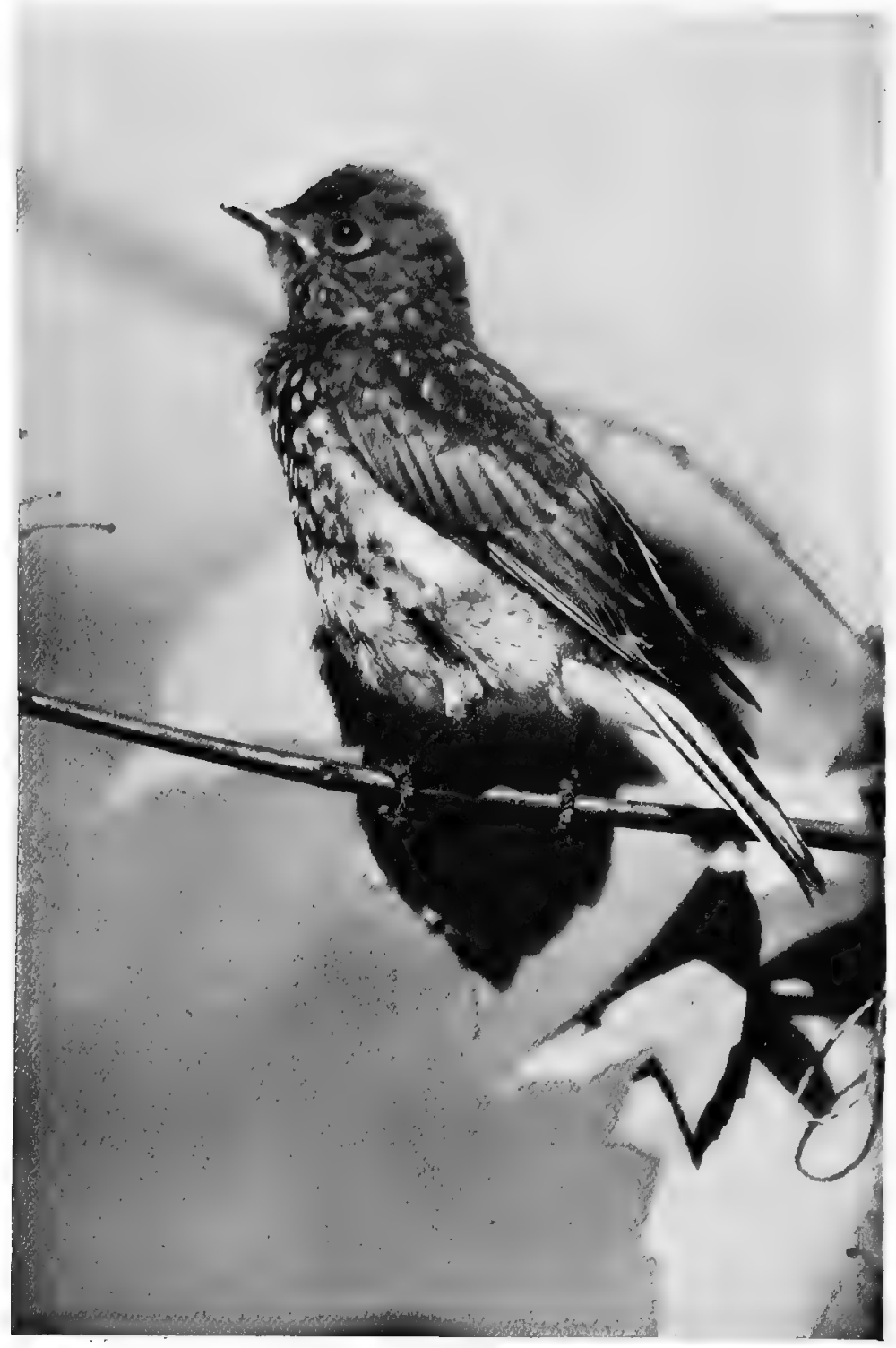

"Bluey." 
that seemed tame and tractable, and carried him home that very day. The parents did not appear to notice the theft, for the kidnapped bird uttered no sound as we carried him off.

From the very beginning he bore promise of having a somewhat unusual disposition; tame, confiding, affectionate and full of little tricks that were an endless source of pleasure to us all. Knowing what his colour would be in the near future, though at present he was spotted with tints of bluish gray, we by common consent bestowed the name of "Bluey" on our pet, and it was not long before he feathered himself to suit his name.

Of course all young birds require feeding by hand until after they reach their full size, and Bluey was no exception to the rule, but, unlike other fledglings, he was by no means content to sit on his perch and be fed in the regular way. He demanded far more attention and, if you please, must needs have a person's finger upon which to stand, while he received mouthful after mouthful of mashed potato and egg. The quantity he ate was out of all proportion to his diminutive size ; in less than two days he would consume an amount of food about equal to his own bulk. As he grew older less food would satisfy him, but still his appetite remained most excellent.

Looked at from the standpoint of an orthodox cage bird, Bluey, during the first few months, could not be considered a success; in fact, he objected thoroughly to being confined to a cage, and fought continually; this, however, was our own fault, as we allowed him so much freedom

W.L.C. 


\section{WILD LIFE AND THE CAMERA}

that he was a regular spoiled child. His cage, with several others, was hung in a large wire enclosure, and of this domain Bluey considered himself absolute monarch; he would go into his cage only for food and water, or to drive out some intruder, for he was cock-of-the-walk, and the other birds gave way to him, even those that were larger and stronger; Fluff and She, the pair of rosebreasted Grosbeaks, were frightened into a state of abject terror when Bluey threatened them, and this he did quite frequently, seeming to enjoy their complete discomfiture. Any attention which we might pay to other birds called forth an angry remonstrance from this little autocrat. $\mathrm{He}$ even objected to any bird sitting on one's shouldera perch he considered his own right and privilege, and one that he fully intended no other bird should share.

At times it became necessary to shut him in his cage, and he would then content himself for a few moments by giving vent to his displeasure in repeated calls-sharp, impatient notes that always showed his lordship was angry. If no one paid attention to him, cage fighting would begin, and he would bang his head against the wires. It was not long before he had torn out all the forehead feathers, and with his little bald head he was not an object of beauty. After taking a bath, which he did once or twice each day, his appearance was positively ludicrous. His mind, however, was far above such things as personal looks, and he became more and more affectionate and companionable, always happy if only allowed to nestle snugly in 
a person's partly closed hand. Then he would go to sleep as peacefully as a child in its mother's arms, uttering a peculiar little chirp as he cozied himself into a comfortable position. He was very particular never to sit in a hand except with his head towards the fingers; occasionally by mistake he got in facing the wrist, but he would immediately hop out, and, turning round, assume his regular position. When in a particularly affectionate mood he liked to rub his beak repeatedly on one's fingers, before going to sleep. This seemed to be a mark of endearment, somewhat after the manner in which a dog rubs his nose against his master's hand. It must be an unusual habit, for in all my experience with small birds I have known of no similar case.

At times, but by no means often, Bluey performed a little trick that was as remarkable as it was beautiful. If one of us held up a hand (and no stranger need apply) and called him by name, he would immediately fly down, and after hovering for some seconds, singing the while, alight and rub his bill several times, usually on the first finger. It was noticeable that he alroays perched so as to face the fingers, and never, even by accident, departed from this rule. Why this should be was a constant source of speculation, and one that I fear must for ever remain among the many mysteries of bird-life. We try, generally in vain, to discover the reasons for the actions of birds, but it is difficult, as we have but our own experiences to go by, and, while birds do most undoubtedly think, they probably do so in a totally different manner from ourselves. When Bluey saw his bath 


\section{WILD LIFE AND THE CAMERA}

being made ready he knew perfectly well what it meant, for he would sit on my sleeve as soon as the large glass tray was taken, and there wait while it was washed and filled with water. The moment it was full of clean water, and even before it was placed on the ground, he would jump in and immediately splash the water in all directions-for he bathed most vigorously, so much so, indeed, that at frequent intervals he had to pause to regain his breath. Our other birds seemed more or less suspicious of the bath, hopping round about it in an undecided manner and getting in and out in a way most aggravating to us who had taken the trouble to give them the pleasure. One bird will never take his bath in the presence of an onlooker, while another always requires to be sprinkled before he ventures in. But then Bluey had more sense than any bird I have ever known; he seemed almost human as he looked into one's eyes, as though he could read one's very thoughts. When called by name he always answered with a chirp, and when a certain note was whistled he knew full well that it was to him we called, and he would reply with a short song of four or five notes, accompanied by a quick flapping of one wing.

That Bluey had within him a soul for music there can be no doubt. The piano in particular appealed to him, for whenever it was played he would sit either on the top of the instrument, on the keys, or sometimes on the arm of the player. No amount of banging disconcerted him. There he sat, with feet widespread and head tilted slightly to one side, as though in thorough 
enjoyment of the music. We were never able to discover whether he had a preference for any particular class of music-Wagner or Mendelssohn or ragtime seemed to suit him equally well.

All birds are more or less observant, and Bluey, being highly developed, noticed most things. Any unusual change in the dress of those he knew was instantly observed and carefully scrutinised; even a necktie of unusual colour required investigation, while the wearing of a thimble, or a glove, might and usually did arouse suspicion, and he would not venture near the hand thus adorned. Many birds object seriously to any shades of red, but Bluey, so far as we know, had no such prejudices.

During the summer, when kept in the large wire enclosure, it often happened, through the door being inadvertently left open, that Bluey would get out; but so tame was he, that after a short fly about the grounds-where the wild birds chased him, according to their usual habit when a cage bird escapes - he would return to any one he knew.

As summer drew to a close (the end of August) Bluey moulted; his spots, which were the signs of his youth, disappeared, and in their place came a fine coat of feathers coloured and patterned like the mature Bluebird. The blue on the head and back was at first bright in colour, but as the year waned there appeared rusty edgings to the feathers, and these somewhat marred the beauty of the blue. His throat, breast, and sides were coloured like terra-cotta, which bordered on the white of the under parts.

Towards the end of autumn we had a severe 
fright on our pet's account, and that day will be ever memorable to us, for we thought the end had come. Bluey's death would have been a real blow, for he had so endeared himself to every member of the family that the loss would have been well nigh irreparable. What had happened no one at the time knew, but Bluey was found on the ground, limp and dazed, apparently in a dying condition. At first we thought he had struck himself against something, and that he was stunned. A little diluted whisky was administered, and he gradually recovered, but for some hours he remained very quiet, sleeping peacefully in the hand of his mistress. When night came, and it was time for him to go to roost, it was with great difficulty he was induced to leave her hand, for he clung to it, as though disliking the idea of being alone.

The following day Bluey seemed to have quite recovered, and he was, as usual, allowed the freedom of the house. It was not long before he repeated the performance of the previous day : while in the act of flying, he dropped down in a fit, and again we thought him dying, for he lay on his back with feet upturned and beak wide open, gasping for breath, his eyes shut. Lifting him gently, we tried to do something; but we soon gave up all hope of his recovery. After a little while, however, his little heart began beating with greater strength; he opened his eyes, and to our great relief and astonishment he yawned, shook his feathers, nestled in my hand, and went fast asleep. The next day passed and he seemed perfectly 
well, and we congratulated ourselves upon what seemed to be his complete recovery. But our hearts sank when during the following morning the poor little chap had two further attacks. In despair we consulted a bird fancier, who told us that it was no uncommon occurrence with soft-billed birds. This was some small consolation, but the remedy recommended did not at all appeal to us. Rush of blood to the head was, he said, the cause, and the cure was to let out some blood by cutting the toe.

Needless to say this was an operation the performance of which we dreaded, but then Bluey must be cured at any cost, and if this was necessary, as the bird man declared, it must be done-and done it was the very next day. The patient did not seem to object at all at the time, although the next day his foot was slightly inflamed. To us the most painful part was that he was not cured, for on both the following days he had fits, proving absolutely that the operation had been in vain. In giving these unpleasant details, it is with the hope that if any one reads these pages, and chances to have a pet bird that is subject to fits, he, or she, will not adopt the above method in trying to effect a cure.

We next tried giving Bluey a complete change of diet; hitherto he had had moist "mockingbird food," which is very rich; now we tried the dry preparation freely mixed with grated carrot, and from that day he was perfectly well and happy, to the infinite relief of all his friends, for he was looked upon quite as a member of the family.

For some months all went well. Bluey was himself again, a healthy, affectionate, and lovable 


\section{WILD LIFE AND THE CAMERA}

kird, but another mishap was in store, and it was one that very nearly proved fatal. He had been allowed the free run of the house, and spent his time in flying about from room to room, investigating everything, devouring any stray flies, crawling in each nook and cranny and nestling for a few moments in places that were to his fancy, -and no one could tell what places he might choose. Those that had been most carefully arranged with special reference to his supposed wants were so entirely ignored that we came to the conclusion that we understood not his whims and fancies. But this capriciousness had nothing to do with the accident that occurred when he was flying through the hall one morning, with the evident intention of joining us at the breakfast table. Someone banged the door just as Bluey was about to enter; he was struck in mid-air and uttered such a piercing cry that we all thought he had been killed. By sheer good luck, however, the door had only bruised the side of his head, thereby changing its shape completely and distorting his beak, so that his whole appearance was altered. For many days he kept very quiet, neither singing nor caring to be petted; but gradually the swelling went down as weeks passed by, and his head resumed its natural size and shape. The result of the accident was shown by his no longer being able to snap his bill (the points not coming quite together) as he used to do when eating. He took his food quietly; even a fly would be caught without the loud snap so characteristic of the bluebird when feeding.

Bluebirds being almost entirely insectivorous, we had to keep Bluey well supplied with various kinds 
of insects. Flies, grasshoppers, beetles, and small moths seemed to be most in demand. Flies he would catch with wonderful dexterity. They were swallowed instantly, often before being killed. Grasshoppers we caught and let loose in the enclosure, and it was extremely interesting to watch the systematic way in which he went about the work of eating them. If several were let loose at once, he would instantly pounce down on them, and deliberately kill one after another by hammering them with his beak. When quite satisfied that they were all hors de combat, he would shake off the legs of each one in turn and swallow the bodies, each at a gulp. Finally he would gather up and eat all the legs; not one would escape his keen eye. The number of grasshoppers he could devour at a meal was out of all proportion to his size. I have known no less than eight to disappear down that beautiful throat within a few minutes.

His method of disposing of a large number of hopping insects shows a great amount of reasoning power (though birds are not supposed to reason). He knew full well that were they not all killed in the shortest possible time some would surely escape. Curiously enough this was not the result of long experience, for when he was but a few weeks old we gave him several grasshoppers, and when he saw their powers of jumping, he then and there made up his mind they would get away if not immediately killed; and he promptly proceeded to kill.

Two years after Bluey's arrival we moved to a house that we had built near a delightful 


\section{WILD LIFE AND THE CAMERA}

little village fifty miles from New York. It was in April, when the bluebirds had just arrived from their southern winter trip. As usual Bluey was allowed his freedom, and greatly did he enjoy flying about the apple orchard, searching with his keen eyes for insects which were to his taste. One day while on an outing he met a little Miss Bluebird. Need more be said? When we called him he simply laughed at us, laughed and scolded as he sat with his bride on the roof of an old barn. There was nothing for us to do but submit to the inevitable. Love had conquered, as it always will, and so we lost our petthe dearest of little companions whose song had so often cheered us and whose delightful ways had been a constant source of pleasure during the two years he had been with us.

P.S.-Nearly a year has gone by since the foregoing was written. A strange thing has happened. In a bird box fastened outside my studio a pair of bluebirds have taken up their quarters. While watching them as they sat on the branch of a dogwood tree that grew near by I called as I used to call Bluey. To my surprise there came the familiar reply and the fluttering of the wing. Was it our old pet? I believe so, for surely no other bird would have answered as he did. For two summers he stayed with us, and whenever I called he would nearly always answer, but we were less to him than his mate. He had tasted freedom, and he liked it better than the restriction we had imposed on his wilful spirit. $\mathrm{He}$ was living the life for which he was made, and we could not find it in our hearts to quarrel with his choice. 


\section{MY CHICADEE FRIENDS}


- 


\section{CHAPTER VI}

\section{MY CHICADEE FRIENDS *}

$\Lambda$ true account of an experience with a chicadee family.

Chicadee, chicadee, chicadee-dee-dee came from among the branches of the swaying silver birch. The same note was echoed from another tree near by. This was in the woods where the ground was dark and damp from the rains of early spring, there was as yet but scanty vegetation, which might be seen trying to force its way through the thickly matted leaves of the year that had gone for ever. The ground was so entirely covered with these reminders of the departed year that one wondered whether this budding spring would have the power to hide the numerous dying skeletons. The trees were in all the tender glory of their new green covering, each one vying with its neighbour in its effort to shade the ground, and to keep the everincreasing heat of the sun from burning the delicate plants that were coming into life in the soil formed by endless years of dying leaves. In all things was the inevitable sign of life. The birds' songs filled the air to the accompaniment of the soft rustling of the leaves.

Again came the sweet call of the chicadee, with the tenderest of answers-"Dee-dee"-and through the interlacing branches flew a small ball of black,

* First published in Everybody's Magazino. 


\section{WILD LIFE AND THE CAMERA}

white, and grey, that perched here and there on the twigs until he came to his mate. They were as alike as two peas in a pod, yet from their actions one could tell, without question, which was which. The one demanded instant waiting on and attention; that was Mrs. Chicadee. The other attended to her every want, and this was $\mathrm{Mr}$. Chicadee. They had evidently been mated for but a short time, for as yet no nest had been built, but then the year was young and there was ample time, so why hurry? Already other birds had young, some were even building their second nest, but were they any better off for all that hurry? Some had had their nests destroyed by the frequent rains, and the chicadees, perhaps, wondered why these birds persisted in building their nests on the ground when the woods were full of trees in which holes of almost any size might be found; and was not a hole in a tree a much safer and more comfortable place for a home than a nest on the ground, no matter how well it might be built? So thought the chicadees as they busied themselves hunting among the many partly decayed birch trees, searching for a suitable hole. At last one was found that appeared to answer all the requirements of our househunting couple. Perhaps it had not " all modern improvements," but what care birds for such things? Enough that the entrance was of the proper size (about two and a half inches in diameter) and inside, with a very little excavating, there would be room for the expected family of seven. The hole was rather deep, running down from the entrance nearly eighteen inches, but by the time the nest 
was built it would be about right. Also the stump was a trifle low, being not more than four and a half feet high, but it is better not to be too particular: he who would search until he finds perfection dies while he is yet searching.

As a rule no bird likes to build its nest while a human being looks on, for well do they know by past experience, that is but too sad, what danger lurks in the human form. How many tales of desolation and misery could they tell if speech was in their power ; tales of hopes blasted at the moment when all seemed most promising, of wholesale death, of entire families wiped out by the thoughtless act of some human creature. Surely is it safer to have little trust and faith in both man and beast. The man will destroy without object or reason, while the beast at least has the excuse that he does so for food! It was, therefore, a surprise to me when Chicadee and his mate began their building operations. After hopping about on the thinly-leaved bushes, and occasionally coming within a few feet of my head, always replying to the call note that I whistled by way of an introduction, they set to work.

" Dee-dee" I had called, and " chicadee-dee-dee" was the answer.

So we were introduced, and they might now get to work, for there was much to be done and only four short days before the first egg would be laid, and a fitting nest must at all costs be made ready. The sky was clouding over and there was the possibility of rain, which would delay the nest-building, as by making the materials wet it would unfit them for a Chicadee's nest, that should above all things be 


\section{WILD LIFE AND THE CAMERA}

dry. So the pair began work, and to watch them was a pleasure that cannot be expressed in words. Such devotion, such patience, such untiring energy, and withal such intelligence, would have commanded the respect and attention of even the most cold-hearted and indifferent person who claims to care for nothing in nature besides man and his works. Many birds have I had the good fortune to watch during their nest building, sometimes surreptitiously and sometimes openly, but never was I impressed as I was by the Chicadees.

Evidently moss was considered a most excellent material with which to lay the foundation of the nest. So Dee-dee, as I call Mrs. Chicadee (for it was in that way she so often replied to her mate), flew to the foot of a partly dead maple tree, whose exposed roots were well covered with a thick coat of short, curly and nearly dry moss. Then with her entire energy and strength she commenced gathering pieces of the moss in her tiny beak. When she had as much as she could carry, she flew to the nest hole, and, without hesitation, disappeared through the entrance, to reappear after a few moments, when she flew directly to the mosscovered roots and once more began gathering material. Just then Chicadee (her mate), who had been absent for some minutes, arrived, carrying in his beak a small greenish caterpillar. Seeing his mate he called, "Chicadee, chicadee-dee-dee." "Dee-dee," in the softest of tones, came from the bird at the foot of the partly dead maple, and he flew down to tell her that he had brought food. She already had several tufts of moss in her beak, and could not 
therefore accept the proffered morsel, rather must she continue her work, for the clouds were gathering in dark masses that promised at least a heavy shower when her moss-gathering must cease. In vain did Chicadee coax; it was all to no purpose ! she must work. Her beak full, she flew to the nest, remained there as before a few minutes and then reappeared. This was Chicadee's opportunity, and he hurried to her before she had a chance to gather any more of the much desired moss. With the most delicate manner imaginable he once more offered the dainty morsel, and she accepted it with a graceful flutter, just as a young girl might on accepting a gift from her lover.

So many writers and others criticise in a severe manner the growing tendency towards seeing, or making believe to see, habits in birds that bear resemblance to our own. In other words, they object to what they call the human side of birds. They consider the claim for it absurd, without foundation, and existing only in minds inclined towards sentimentality. That the tendency may, like all tendencies, be carried too far, beyond the bounds of reason, is quite true, but, Mr. Critic, have you ever observed birds, whether at large or in captivity? If so, you must surely have little powers of observation, or perhaps you see through the spectacles of prejudice, for otherwise you could scarcely fail to find in birds counterparts of both our faults and our better qualities. Jealousy is nearly as strong in birds as it is with us, and we find it shown in exactly the same ways. Anger, good-nature, suspicion, confidence, constancy, inconstancy, hatred, love, selfish-

W.L.C. 


\section{WILD LIFE AND THE CAMERA}

ness, generosity, all these we see in the most humble of birds. There are, in fact, but few traits in man's character that have not their counterpart in birds, and yet you object to what you term with derision "the human side of birds."

Watch birds during the spring season, and see how the male bird tries by every way in his power to make himself attractive to the object of his affections. If occasion demands-and frequently he will search diligently for an occasion-he deems it his duty to fight, and thus show off his superior power and strength, just as in the days gone by, men, dressed in all the finery of knighthood, threw down the glove and fought for the maid, whose hand they hoped to win. Watch the male bird's gentleness and gallantry as he offers his partner any chance tit-bit that he may find, and notice well that seldom, if ever, does the one of the gentler sex make any advance. Perhaps you may call attention to the fact that, with birds as with animals, it is the male that has the greater beauty. It is he who makes the show and display. Quite true, but it is not so very long ago that with the human race it was the man who used to adorn his person and endeavour to make himself an object of beauty, and the woman that lacked the adornments. You will still find it so among some of the barbarous tribes. There must be reason for the male bird having the fine colours; were the female as conspicuous as the male she would be in greater danger from her enemies, especially during the period of incubation. This alone would be sufficient reason for her more quiet dress. But to 
return to our Chicadees. No sooner had Dee-dee swallowed the morsel of food and wiped her beak on a twig, than she began again to gather moss, while her attentive mate, after watching her in an admiring way for a few seconds, flew off in search of further dainties for her who worked so hard. 'Throughout the two hours or more before the rain came he would continually bring caterpillars and other delicacies and, when he found her busy, would with admirable patience wait near by until she was at liberty to accept them. Never once did he eat the food, even though at times she kept him waiting as much as five minutes while she gathered moss and arranged it to her satisfaction in the dark hollow of the stump.

At the end of these two hours, large drops of rain fell, gently at first, then gradually faster and faster, until from each green leaf the drops hung like clear round crystals, that were shaken off whenever the cooling breezes passed by and moved the gem-laden branches. It was no time for nest building, and Chicadee and his mate flew off among the trees and were immediately lost to view. The next day was bright and clear after the rain, and the Chicadees had resumed their interrupted labour long before I arrived. More moss had been gathered and placed in the hollow of the decayed birch stump, and on the top of the moss was placed a thick layer of a strange material, nothing less than the silver grey hair of the 'possum," stolen, no doubt, from some

* All the chicadees' nests that I found in this locality (South Orange, N.J.) contained quantities of opossum hair. It is curious, because 'possums are by no means common in the vicinity. 


\section{WILD LIFE AND THE CAMERA}

mother 'possum's nest in the hollow of a tree or among the rocks. Wherever obtained, it seemed to be exactly what Mrs. Chicadee wanted, judging from the number of loads she had brought.

In all it took four days to build the Chicadee's nest, and when completed it was the softest and coziest of homes. Some sheep's wool and some soft, silky plant-down had been used with which to finish it. It was a suitable receptacle for the tiny, speckled, pinky eggs that were placed in it, seven of them being hidden in the soft bed of wool and down. On these the old birds sat by day and by night, seldom absenting themselves from the selfimposed task that must at best have been tedious. Whenever I visited Dee-dee as she sat in the dark obscurity of the hollow stump, she would look up in an inquiring way, her whole appearance seeming to beg that I should not disturb or injure her. Was she not, in the performance of her duty, carrying out the great law of the propagation of species? Knowing full well how helpless she was, penned up in the partly decayed stump, she placed herself and her precious eggs entirely at my mercy. Needless to say she was not disturbed in any way. On holidays, when thoughtless boys roamed the wood, bent only on having what they considered " a good time," sparing nothing that came their way, I would stay within sight of the Chicadee's nest to see that no harm should come to it. No boys would have been likely to discover the nest, simply because they would think it improbable that any bird would build in such a decayed, fungus-covered stump, but in passing they might have pushed 
against it, and that would have been the end of one brood of these cheerful little acrobats of the summer and winter woods, and by just so much would the world have been the poorer.

Days passed. Days of sunshine and days of showers, all helping in the fulfilment of the promises of spring. The trees became more thickly covered with leaves, and on the ground the dead leaves were almost hidden by the new growth that was daily becoming more abundant. The earliest flowers had come and gone, and in their place were the drying seeds, on which the flowers must depend for their continuance. Another year must we wait before the many-hued hepatica, the snow-white blood root and the nodding yellow bells of the adder-tongue would again grace the woods. The violets were now flowering in all the glory of their royal colours, and here and there might yet be found clusters of pink azalea scenting the woods with their delicious perfume. In the damp, woody swamps the fragrant clammy azalea was just about to burst into bloom, to give the summer foliage the appearance of having received a slight fall of snow, so white were its flowers. Birds were busy carrying food to their different broods, pausing between whiles to sing each one its own particular song of exultation, from the soul-stirring chant of the wood-thrush to the jerky notes of the red-eyed vireo; each doing what lay in his power to ring up the echoes of the summer woods.

Among all the songs the small but exquisite note of the Chicadees sounded as they searched diligently among the leaves for food. A newly-arrived 


\section{WILD LIFE AND THE CAMERA}

brood had at last rewarded their long patience. Backwards and forwards flew these devoted parents, giving no heed to anything save feeding and watching over their young. What else was there to think of? For nearly a month they would do nothing else. All would be devoted to the rearing of their offspring; everything sacrificed, and apparently with pleasure, too, to their welfare.

The young Chicadees grew apace as is the habit of young birds. From tiny grey atoms, largeheaded, blind and naked, having in them but the one instinct-that of raising their heads at the slightest sound and opening their mouths for the frequent meals, they gradually turned into small, open-eyed, down-covered balls of fat. Then pin feathers began to cover their growing bodies in lines that ran lengthways, leaving bare places between. Then the pin feathers opened, and from them emerged the soft young feathers. Hour by hour showed the covering up of the bare places by the spreading of the feathers; and the small bodies were clothed.

The young birds were growing very large for the snug nest and without doubt must soon be thinking of seeking the wide world, where there was room and to spare. Day by day I had watched them as they grew, and my watching was very nearly the cause of a most unfortunate accident. In my endeavours to see inside the nest I, quite unintentionally, broke off a large piece of the decayed bark, thereby exposing the nest and its valuable contents, very much to my own and the Chicadees' disgust. Loudly did they express their feelings as they flew about my head. Evidently they expected to see 
me devour their entire brood. To mend the nest was the next step. It was easily accomplished, for all the necessary materials were close at hand. A large piece of birch bark was peeled from a tree that had been blown down during a recent gale. This I put on the stump, sleeve-fashion, lacing it, on the side furthest from the opening, with a piece of wild smilax vine. After cutting a hole in the birch bark patch and inserting a few broken twigs here and there, and generally making the new patch look as much as possible like the bark on the decayed stump, I retreated to a little distance that I might watch the effect. There was, however, but little to watch. Both Mr. and Mrs. Chicadee, first one and then the other, entered the repaired nest after only a casual glance. Evidently they had no objection to the change, and so once more things went on as usual, though it was only for a few more days; the time was drawing near when I was to prove whether or not I had gained the confidence of my Chicadee friends.

The day came at last, a fine, bright, sunny day, though intensely hot, and the young birds were to make their bow to the great world. I had brought with me all the necessary photographic paraphernalia with the hope and expectation of obtaining portraits of the Chicadee family. Hitherto I had only secured photographs of the parent birds going in and out of their nest, and these, though interesting, were as nothing compared with what I imagined I should get. It is well to be sanguine, to hope for things that never will be, for otherwise even our greatest enthusiasm would be short-lived and our successes 


\section{WILD LIFE AND THE CAMERA}

would be even fewer than they are now-so my hopes were placed on the topmost rung of the ladder.

Chicadee and his mate were both present when I unfastened the birch bark sleeve that I might see if the youngsters were, as I fully believed, ready to leave their warm nest. Not for long was I left in doubt. As I placed my finger gently beneath one of the small living balls of fluff there was a quick movement, a fluttering of small untried wings, and seven tiny Chicadees were instantly scattered among the surrounding bushes. Such an excitement as there was! "Chicadee! Chicadee! Chicadee-dee-dee!" called the parent birds as they flew backward and forward, up and down, from bush to bush, from twig to twig, up in the trees, then down on the ground, urging the young birds to greater efforts, helping the weaker with emphatic birdwords of advice. All was confusion. All the birds in the neighbourhood arrived, each one willing but powerless to offer any assistance. The yellowbreasted chat, whose nest was in the huckleberry bush near by, let her young go hungry for a time, while she came carrying their meal in her beak, adding her cries to the many that filled the air. From all sides could be heard the distressed calls of the birds; vireos, cat-birds, tanagers, warblers of many kinds, blue-jays, wood-thrushes and many others, each one excited and trying to outdo his neighbour in vocal remonstrance. Suddenly, and with no apparent reason, the Chicadees quieted down, when immediately all the other birds became silent, and one by one returned to their homes and their duties. 
Now it was that my work began. In vain had I attempted to follow the various courses of the fledgelings, but nature had allowed me only two eyes, a number quite insufficient to keep up with the vagaries of seven Chicadees, young and inexperienced though they were. There was nothing to do but to institute a long and careful search, a test of patience against instinct, the former gaining the day, for in about an hour I found all of the seven youngsters. It is curious that, once found, these Chicadees no longer seem to entertain that keen desire to get away which characterises most young birds under similar conditions. On the contrary, they behaved most admirably, being quite content to sit on my hand or on any branch I might select, provided only they were shaded from the fierce glare of the sun; and just here lay my greatest difficulty, for instantaneous photographs are not made in the shade, and the movement of birds is so rapid that one twenty-fifth of a second is about as much exposure as one may safely indulge in. This means that the subject must be well lighted, a condition which my little Chicadees thoroughly objected to. If I placed them, one or all, on my knee, and my knee happened to be in the sunlight, without a moment's hesitation they would scramble to the nearest shade, even should it be but a fold in my clothes.

Both Dee-dee and Chicadee seemed somewhat astonished to see their young ones sitting so complacently on my knee, and doubtless they wondered what next would happen. So far they had seen no reason to fear me, for I had done them no harm, 


\section{WILD LIFE AND THE CAMERA}

but now that I had their young so clearly in my power it might be different; at any rate, they were determined to watch me, and for this purpose they stayed very near, calling occasionally "Chicadee, chicadee-dee-dee," to which the youngsters in quaint imitation would reply, but "Chica-chica-dee"-or about as near as they could get to it-seemed to please the old birds. It required some time to prepare for the photographic work, but at last, everything being ready, I had only to wait for the parent Chicadees (who by this time had become quite used to the very novel situation) to come on to my knee, for that was the sort of picture I wished. It is needless to say that I was surprised to find how little coaxing was required. Only one call from the young, and Dee-dee replied in person by coming on to my knee, where her children were bunched together, just as though it was the most natural thing in the world for her to do. She brought no food with her, however, so the seven youngsters fluttered, chirped, and opened their yellow-lined mouths in vain. Evidently Dee-dee came with the single idea of satisfying herself of their complete safety; this being assured, she flew away to receive from her mate a caterpillar of that kind commonly known as the inch worm. This she prepared by eating both the ends, which are armed with feet. Scarcely a minute being required for this, she came directly to theimpatient brood still wondering in expressive tones at the unusual delay of their meal-time. Perching on my knee, she singled out one of the seven, apparently without any particular reason, while the remaining six looked on with 
quaintly dismal and dejected expressions. 'To silence and satisfy the entire brood seemed now the one thing necessary, a fact which appeared to be thoroughly appreciated by both the old birds, for they worked as though their lives depended on it. Over and under each branch they climbed, examining both sides of every leaf, and woe to the caterpillar or spider that tried to hide from their bead-like eyes, for instantly he was seized and brought to appease the young hungries, until, one at a time, they were all filled and asleep, for with young birds sleep follows food just as surely as summer follows spring.

I had secured several photographs of the family on my knee, and now I wanted some that would show them on my hand, so after allowing my young charges ten minutes' sleep I began by placing one of them on my hand, at the same time holding the bulb (that released the shutter of the lens) in the same hand, but before I could pick up a second fledgeling, Mrs. Chicadee came, without food, and perched on the nozzle of the bulb, so, not wishing to lose the opportunity, I pressed the bulb and secured a photograph of the unique situation.

So far neither of the parent birds had actually perched on my hand, but judging from their former behaviour I felt not the slightest doubt that they would do so. Dee-dee, seeing that the little one sitting on my finger was in that chronic state of hunger so peculiar to young birds, left with the evident intention of finding something with which to satisfy him. Chicadee had, however, anticipated 


\section{WILD LIFE AND THE CAMERA}

her, and brought an insect suited to the needs of a fledgeling. Dee-dee approached him, fluttering her partly closed wings just as the fledgelings did when they wanted food.* She was evidently begging the food from him, and he, being of an unselfish turn of mind, gave it to her with a flutter and a soft note which seemed to say, "It is yours, do what you wish with it," and he followed her almost to my hand, as she came flying in response to the calls of the handful of fledgelings. Seeing her approach, each one struggled to be nearest to the promised morsel. Just before she perched on my hand, I pressed the bulb with the result shown in illustration. Having delivered herself of the food to the great satisfaction of only one of the youngsters, she stood still a moment and looked up at me with a quizzical expression, and then flew off. Scarcely had I changed the plate in the camera when she came back again and remained on my hand for some time. After having once come to me, and finding nothing to fear, she came often, and so did Chicadee. Sometimes they sat together on my shoulder or my hat, and whether I moved about or remained quiet made no difference to them.

Sitting there in the clearing that adjoined the woods in which was the nest of this interesting family of Chicadees; surrounded by sweet-scented myrtle and the huckleberries, whose tiny green fruit was hanging in small clusters; at my feet the exquisite waxlike balls of the stagger bush, than which there are few more dainty or beautiful flowers,

* This is a rather peculiar babit of the adult chicadee, which may be noticed during the spring and summer months. $-\mathrm{A} . \mathrm{R} . \mathrm{D}$. 


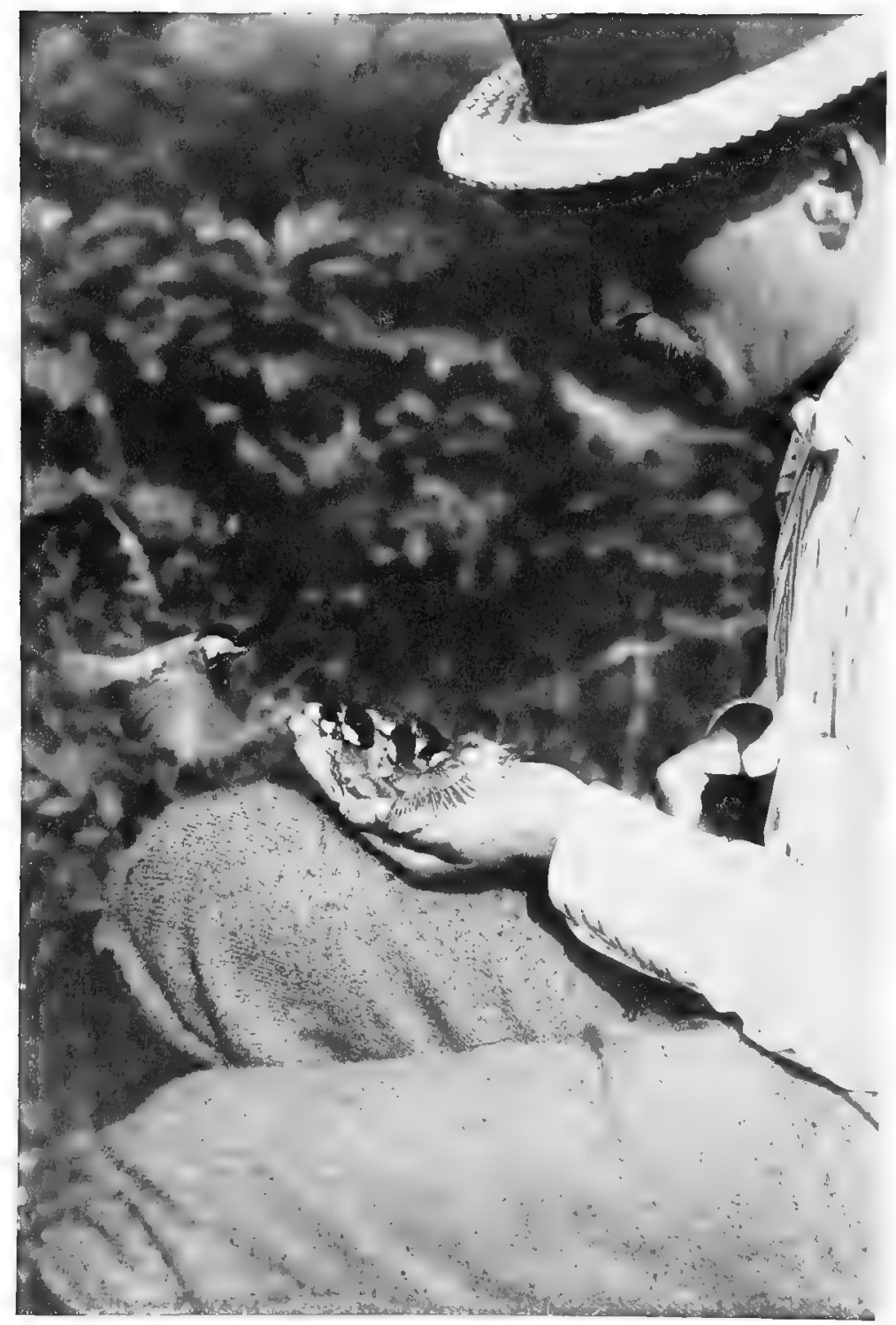

(hicarlee llying to ny hand, in which sit the Hungry Brood. 
I thought that for once at least I must be fairly close to nature in one of its happiest moods, and in all the splendour of the fullness of summer. For there were birds, both young and old, trusting me with confidence, the old ones flying about as though thoroughly agreeing to this strange friendship; now on my hand, now on my shoulder, sitting so close to my face that I could with my cheek stroke both Chicadee and his confiding mate. Their soft feathers against my skin, and their small warm feet on my fingers gave a thrill that went through my system, leaving a glow of pleasure such as one seldom has the good fortune to experience.

What was it that gave this pleasure? Only the immediate presence of some very small birds, birds that so many people know not even by name. What was there in this to give that strange thrill? Each time a bird comes to me of its own accord I feel it, and am repaid a hundredfold for any hardships I may have encountered in trying to make them realise my friendly intentions. At first, as a bird comes near, inquiry showing in its every move, one's heart throbs with the great pleasure of anticipation, that pleasure which is so often the end of our dearest hopes. Nearer and nearer comes our would-be friend, and harder and harder does the heart beat, until we dread that its throbbing may frighten away the bird, and we hold the breath and wish the heart would make less noise. There is a choking sensation in the throat, such as one feels when listening to beautiful music, as the bird finally comes on one's hand, and the realisation of a thing accomplished seems to release the heart, 


\section{WILD LIFE AND THE CAMERA}

and breath comes freely. The bird has touched one's hand and-well, what more is needed?

'The day had been a fortunate one, and one that I would always remember with the greatest pleasure, for it had seen the culmination of the most delightful friendship I have ever had with any birds, and besides that I had secured some interesting photographs that would prove to my sceptical friends how tame the birds had become.

Before leaving the Chicadees I had replaced the youngsters in their nest, in the hopes of finding them there on the following day. How long they remained in their comfortable quarters I never knew, for early next morning when I visited the nest it was empty. Was it possible that any accident had happened to them? If so, perhaps I was to blame. While thinking this over and regretting having fallen into the temptation of making friends with these birds a small clear voice from a tree near by called "Chicadee-chicadeedee-dee," and there was one of the old birds, and with her on the same branch sat two of the young ones; that the others were not far off I felt sure, and a little searching soon discovered them. They were all safe and very busy, for they had much to learn, and I watched them during many hours as they climbed among the branches, learning from their parents all the acrobatic feats of their kind, but eating nothing except what was given them. It would be a couple of weeks or more before they fed themselves, and long before that time they would be full grown and exact counterparts of their parents. Judging from the fact that Chicadees are 


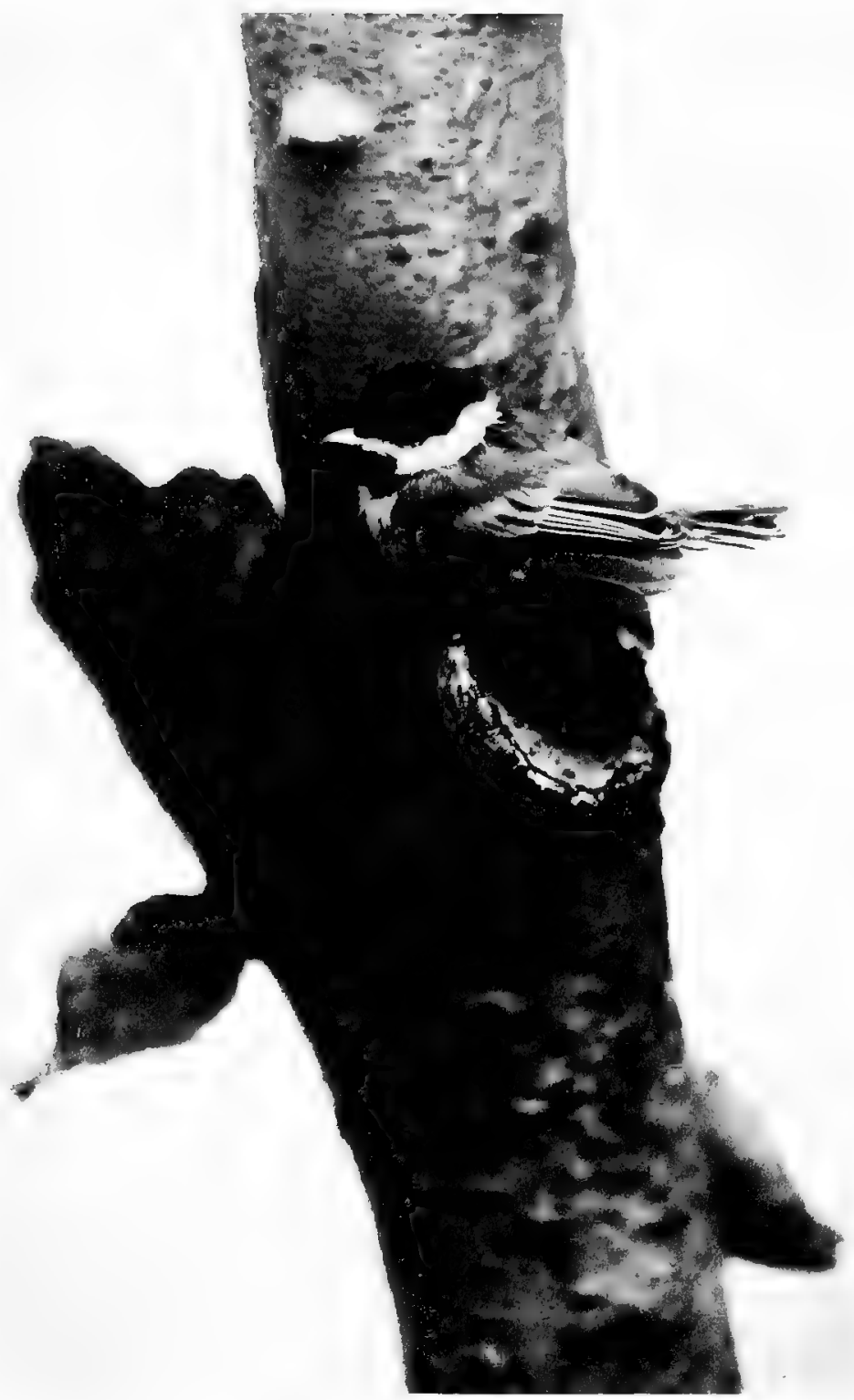

One of the Young Chicadees. 

so often found in small flocks of seven or eight, it seems more than likely that each family remains united until the approach of spring and the nesting season.

The last I saw of my Chicadee friends was towards the end of summer, when the glory of the year was passing. The leaves on the trees had lost their fresh green colour, and most of the plants had finished growing. Insects were searching for places where they might safely hide their eggs until the following spring should come, and the Chicadees, as they hunted for these insects and their eggs, were doing their part in the great order of the things of nature. 

THE WARBLER FAMILY

W.L.C. 


$$
\text { . }
$$




\section{CHAPTER VII}

\section{THE WARBLER FAMILY}

A hitherto only partly published account of my first intimate friendship with a wild bird; the photographs being probably the first ever made showing the extreme tameness of these shy birds (1900).

To form a friendship with any bird, no matter how common a bird it happens to be, is a privilege that unfortunately but few of us human beings enjoy. But when the object of one's friendship is a bird that may be considered rare, that is unknown except to the comparatively few who are directly interested in bird life, the privilege is greater and therefore much more to be appreciated. So it was with my little friends the pair of worm-eating warblers (can we pardon science for having bestowed such a name on this graceful bird?), who, with their family of four, lived not more than a few hundred yards from our home. It was entirely by chance, as is usual, they say, with important discoveries, that I had the good fortune to meet these birds. They have no song with which to fill the woodlands and attract the attention of the casual passerby, only a chirp that is no louder than that of the grasshopper; in fact, it might easily be mistaken for that insect's peculiar note. Neither are they arrayed in "crimson and gold." Their dress is quiet and inconspicuous, yet delicate and beautiful in the extreme: olive-green back, buff-coloured breast, while the head is light buff with very dark stripes. Is it to be wondered, then, that a bird of 


\section{WILD LIFE AND THE CAMERA.}

such subdued colouring and quiet habits should be practically unknown? The way I chanced to find them was this :

While walking slowly through the woods I heard the note of a downy woodpecker. The note was repeated with such frequency that I half suspected a brood of young were starting out on their life of tree-climbing. On the chance of seeing so interesting a sight I made my way quietly through the underbrush with which the hillside was covered. As I came near to where the woodpeckers kept up their steady calling, my attention was arrested by a lisping note repeated at regular intervals; that it was the alarm note of a warbler I had no doubt, and I determined to discover which one of that large and varied family it might be.

The heavy foliage of the trees served well to hide so small a bird from view, and it was some time before I finally detected a worm-eating warbler perched on a branch within a few feet of my head. From his manner, which showed great excitement, I judged that either there was a nest near by or that some youngsters were hiding in the underbrush at no great distance. So, removing my evidently unwelcome presence to a point of vantage, I quietly observed the behaviour of these uncommon birds. After watching for a short time, another bird appeared, evidently the mate of the one I had seen. The two consulted together, and after a few more chirps one began descending, hopping from branch to branch, each time getting nearer to the ground, then suddenly she dropped among the weeds and was hidden from view. 
Carefully marking the place, I hastened towards it, but scarcely had I taken half a dozen steps when up she flew, and once more gave voice to the note of alarm. Thinking that of course I should experience not the slightest difficulty in finding the nest, for that there was one I felt convinced, I went straight to the place from which she had flown, but no nest was there-at least I could find none-so once more I retired from the scene, this time taking greater care to conceal my presence. Evidently the warblers thought I had taken my departure, for after a lapse of about ten minutes one of them flew down and, alighting on a weed stalk, carefully surveyed the surroundings; things seeming to her entire satisfaction, she made straight for her nest, but it was not within several yards of where she had tried to mislead me into believing it was. This time, however, I waited to make perfectly sure, and as she did not appear again I felt there could be no doubt about it, so I approached quietly, and much to my delight discovered my cunning little friend (that was to be) sitting on her carefully concealed nest.

Not moving a muscle, she allowed me to examine her minutely, and I wondered at her cleverness in taking such advantage of the surroundings. The nest was placed in a slight depression-whether made by the bird or nature could not be knownbeneath the partly-exposed roots of a shrub. No rain could possibly enter the nest, as the earth formed a mound above and shed the water as it trickled down the steep incline. A more perfect protection could not have been devised. Not wishing 


\section{WILD LIFE AND THE CAMERA}

to disturb the confiding and patient little creature, I retired in ignorance of what she was guarding so carefully.

'The fact of not having seen either of the birds carrying food led me to suppose she had eggs. If so, it was to be expected that the following morning by 8 or 9 o'clock the sun's rays would creep through openings between the tree tops, and, keeping the eggs warm, would allow the small bird a short rest from that self-imposed but surely tedious task of incubating, and then I could get a glimpse at her treasure, whatever it might be. And so it happened, for when I returned in the morning the sun had taken the mother bird's task in keeping warm the four pinky-white bespeckled eggs. Taking one out of its casket I examined it with transmitted light. Through the thin shell I could clearly see that it would be but a matter of hours, or at most one day, before the young would arrive.

The parents both seriously objected, I fear, to this act of what I trust was pardonable curiosity, so I quickly returned the frail egg to its proper place, and stepping back a few paces watched the excited birds; nor had I long to wait, for they, knowing full well that their home was discovered, made no attempt at concealment.

One of them-we must suppose it was the female, but as they do not show any difference in colouring or marking I could only surmise-made straight for the nest and, after looking carefully at each egg to see that no ill had befallen it, arranged herself comfortably with feathers fluffed out, so that she appeared nearly double her proper size. Then she 


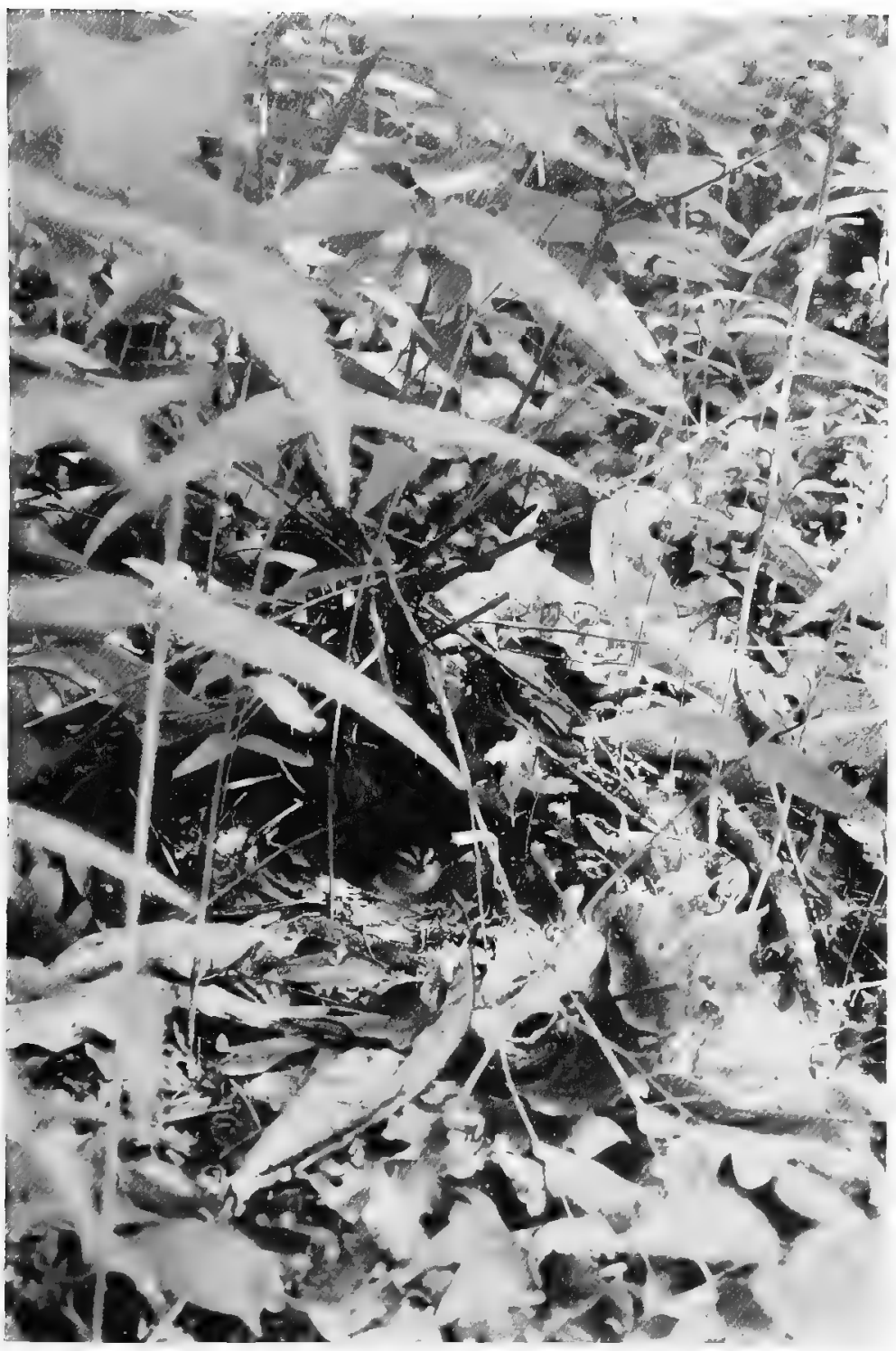

The Worm-eating Warbler on her N'wt. 
sat watching my every move in an interested, but somewhat suspicious way.

Of course I must have a photograph of her as she sat guarding her home and eggs. 'The greatest care had to be observed in manipulating the camera so as to avoid making any sudden movement, for that will usually frighten a sitting bird, even when she is not of a naturally timid nature. Certain weeds and leaves had to be removed in order that the bird might be clearly shown.

Evidently she was beginning to place confidence in me, for she allowed a twig to be broken off that was within a few inches of the nest. The camera was finally arranged in proper position, and who will say what she thought of the strange, threelegged monster that stared at her with its large single eye? She watched it intently, and I was able to make an exposure of three seconds, for I was using the single combination of the lens, as the sunlight had crept slowly away from the nest, leaving it in the shadow of the tall trees.

After making still another exposure I took the camera away, and returning, took a seat quite close to the nest. This I did that the bird might be accustomed to me, as I had in mind the time when I should want to photograph her youngsters. So long as I remained she never left the nest, but going to sleep, showed plainly that she no longer had fear of me. All this time her mate stayed. near by, hunting incessantly among the leaves for his insect food. Sometimes, as though to vary his fare, he would devote his attention to the bark of the trees, creeping up and down somewhat after 


\section{WILD LIFE AND THE CAMERA}

the manner of a woodpecker, searching each crevice in the hope of finding concealed some insect that was especially to his taste, and so I watched for an hour or so, never tiring of performances so interesting. Then, bidding them a temporary farewell, I went off to call on other of my bird friends.

Owing to an unfortunate combination of circumstances, many days passed before I was again able to visit my friend of the hillside. It was a disappointment, as I should like to have seen the young when they first arrived. As it was, I found them pretty well grown, for nestlings, and I knew that in a day or two they would be strong enough to brave the great world under the able guardianship of their parents. They seemed to be a fine healthy brood, each bird being of about equal size. I mention this fact because it very frequently happens that there is a weakling among the family, one that for some cause or other does not grow as fast as his brothers; whether it is that he does not get his proper share of food, or that he was hatched a day or so later than the others of the brood, I have never been able to ascertain. But here was a case where all had happened as it should in a well-regulated family, and I was glad that it was so.

The parent birds were not much disturbed when they saw me examining their family, but when I took one out, that I might the better note his budding feathers, the anxious mother instantly flew to my feet, and with spreading wings and tail she tried to lure me from the nest by pretending some mishap 


\section{THE WARBLER FAMILY}

had befallen her. It did not take her long to discover that she had failed in her ruse-that ruse, time-honoured, yet always new in its pathetic simplicity-and she tried new tactics; but these also failed owing to the youngster not being sufficiently developed. She tried calling him away from my hand, as though she were going to feed him, but the little fellow was not yet strong enough to balance himself on my finger, let alone fly to her. To ease her mind, I placed him back in his nest, that the family had already almost outgrown, and as I did so, I wondered whether by chance the egg I had held in my hand was the one from which this bird had come.

He seemed well satisfied to be with his brothers and sisters, and soon nestled himself amongst them, forming his part of the heaving mass of down and feathers.

The next time I visited the nest the warblers made no objection, and I imagined they recognised me and realised that I meant no harm either to themselves or to their young, for these had hatched out since my first visit. Day by day I came to watch the little fellows, and they grew rapidly, as all young birds do. Finally, they were ready to make their first venture into the great world that, should no accident befall them, was to be their feedingground for many years to come.

As I looked into the nest the family of fledgelings scrambled out as though they had been scattered by some invisible hand, so nearly simultaneous was their action, and in less time than it takes to tell it each little mite of down and rust-coloured feathers 


\section{WILD LIFE AND THE CAMERA}

was hidden among the dead, crackling leaves with which the ground was strewn. Though I had tried my best to watch where each bird concealed itself, it was some time before I collected them all preparatory to photographing them. Of course the parents were greatly excited-birds always are when their young first leave the nest-and when they saw the entire brood captured by one whom they had considered a friend, they seemed to regret having placed so much confidence in me. But only for a very short time did their doubts continue. As soon as I placed the youngsters on a suitable perch they both ceased to utter that lisping note of anxious protestation, and to show that they no longer feared me they hopped about on the camera while I was arranging it.

When young birds (before they can fly) are placed on a perch they invariably fall off almost as fast as they are put on, and there is usually a bad one in the lot who positively refuses to sit anywhere he may be placed. Not only does he fall off, but if possible he grabs one or two of his small companions, and down they go together. These young warblers were no exception, and off they went, one after another. The bad one proved to be very bad indeed, and he is shown in only two of the many photographs I made of the family.

While the pictures were being taken one of the parent birds stayed near by to watch over her youngsters, while the other went off in search of food, for which they called continually, and though I was not more than three or four feet distant, she fed them without troubling herself at all about 


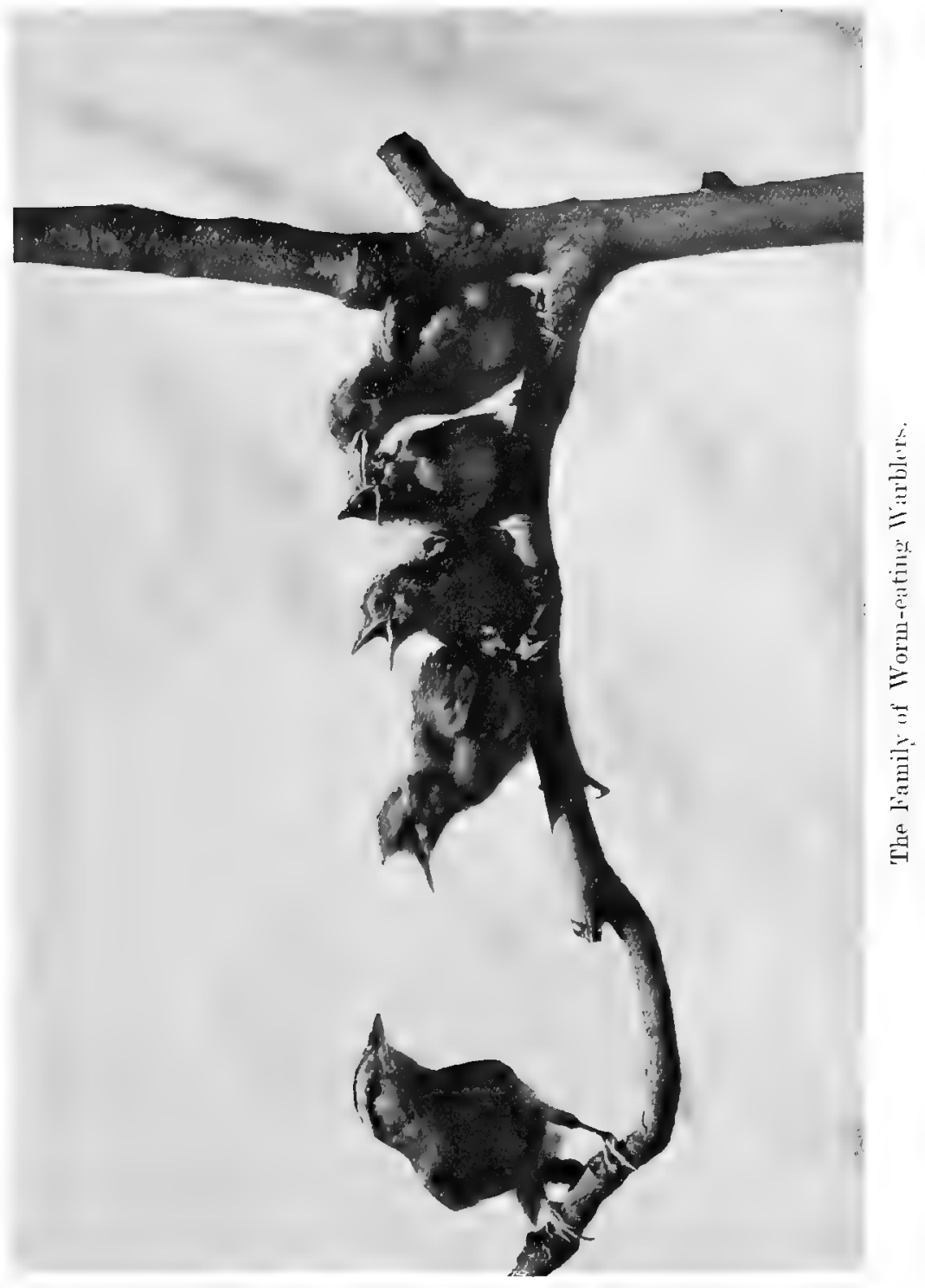


my presence. Once she even perched on my hat and used the camera as a half-way house, resting on it each time she went back and forth to supply the fledgelings with food. Unfortunately the light was not very good for instantaneous photography, but such an opportunity for securing pictures of this comparatively rare bird was not to be missed, so I made many exposures on her and her young, with fair results.

From a photographic standpoint they were faulty, but the subject was sufficiently interesting to warrant one's overlooking the shortcomings. The light had grown so weak by the time I had made about fifteen exposures that $\mathbf{I}$ was forced to abandon any further attempts with the camera for that day. Sitting down on the ground, I placed the young warblers on my lap to examine them carefully. Imagine my surprise when both the parent birds came on my knee, first without and then with food for the youngsters. It was quite a novel sensation, and one that was more than enjoyable. It was positively thrilling.

Knowing from past experience how sceptical people are when told of anything that they themselves have not seen, I made up my mind then and there to pay my warbler friends another visit early the following day, and photograph the old one on my hand. The day was fine, and I was fortunate enough to find one of the young ones, who could now fly a little, perched on the low branch of a small bush. One of the old birds was hunting busily for insects. Seeing me pick up her baby, she flew toward me, but did not object in the least 


\section{WILD LIFE AND THE CAMERA}

to my taking temporary possession of it. So I felt sure that she recognised her friend of the previous day. A few moments sufficed to arrange the camera in a place where the light was bright, and when all was ready to my satisfaction, I took the little fellow, who had been quietly sleeping in the warm sunlight, and set him on my finger.

Soon he called lustily for food, and it was strange to see how quickly his parent heard and understood. In a minute or two she came hurrying along, carrying in her beak a daddy-long-legs, and, after pausing on the camera to see that all was right, she flew on my hand, and calmly fed her hungry little one. With my disengaged hand, I pressed the bulb, and a picture was secured.

The daddy-long-legs served only to whet the appetite of my small friend, who cried out eagerly for more. Again the industrious provider went oft in search of other and larger insects. She was away for some time, but what she brought back fully compensated for the long wait--of perhaps four minutes. It was nothing more nor less than a huge brown grasshopper, nearly as long as the small bird himself. Again was the camera used as a halting-place, and again did she fly on my hand. Hungry though the little fellow may have been, he was unable to swallow so large a mouthful, and he dropped the grasshopper into my partly closed hand. Unfortunately I had just pressed the bulb and was therefore unable to take a photograph of the interesting proceeding that followed.

Quite naturally the mother bird was anxious that so bountiful a supply of food should not 


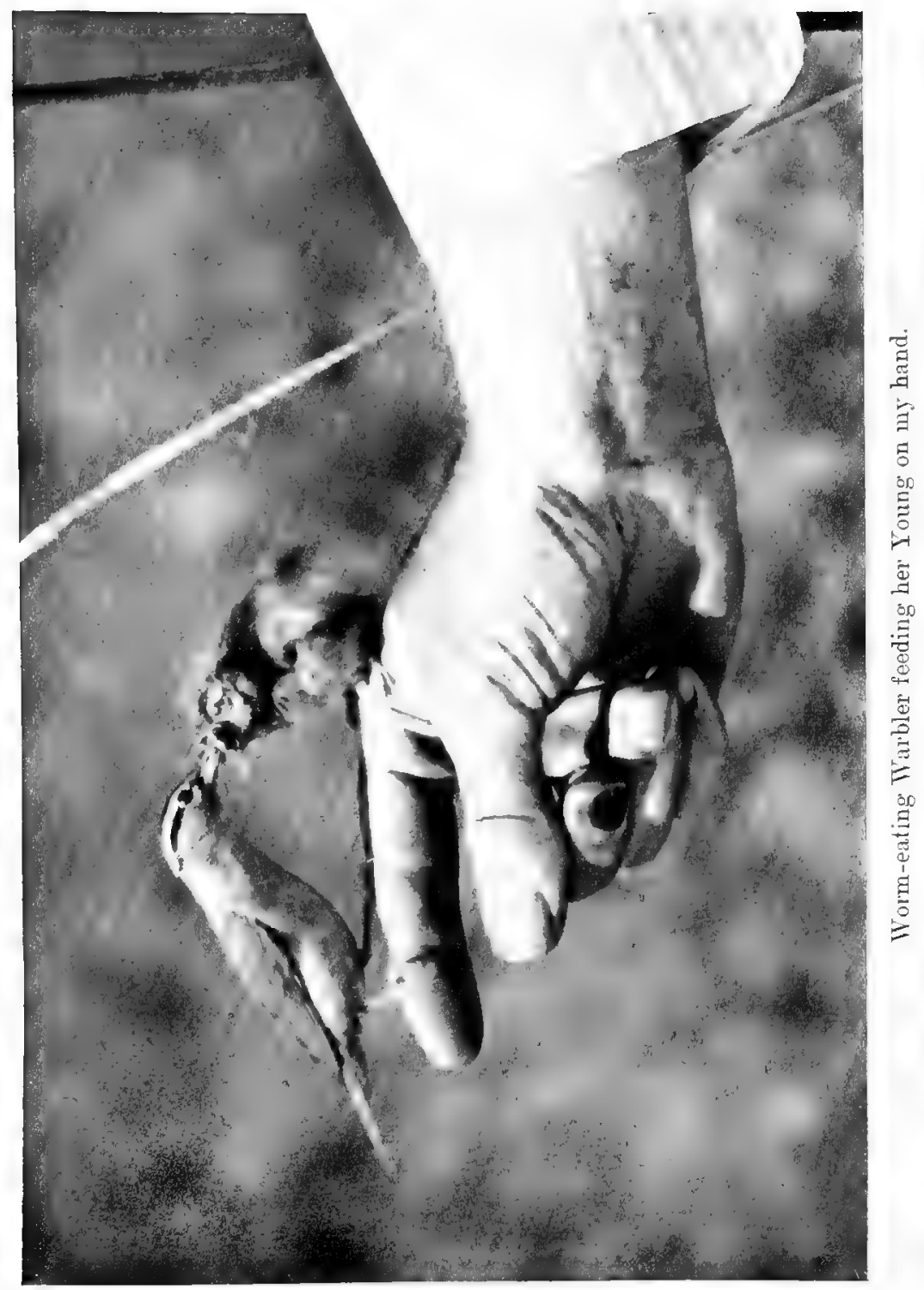





\section{THE WARBLER FAMILY}

be wasted, and she stood on my thumb and, bending down, so that her head was inside my hand, extricated the prize. Then she proceeded to break it into pieces of suitable size, and with these she fed her quivering and impatient little offspring. During the morning I secured a few more photographs of these interesting birds, and then returning the youngster to the bush whence I had taken him, I left the pair in possession of their hillside estate and returned to my home with abundant proof of the tameness of my warbler friends. 



\section{THE VIREO AND THE COWBIRD}





\section{CHAPTER VIII}

\section{THE VIREO AND THE COWBIRD}

T'He following account of a first-hand observation with a red-eyed vireo, though not by any means extraordinary, is nevertheless interesting, as demonstrating the birds' powers of reasoning in dealing with what is not in any way a regular occurrence in the daily life. To argue that the birds' actions were entirely according to natural instinct would seem scarcely fair to the little feathered creatures who acted with such far-sighted intelligence. In mentally attempting to deprive them of their reasoning power we might question the wisdom of their action. From an economic point of view, would it not have been better to have built a new nest rather than change the first one? But would the result have been any different? It probably required no more time to make the change than to have constructed an entirely new nest.

When birds build their nests they appear to have certain well-defined objects in view. The nest must be well concealed or out of reach of many enemies, and due care must be observed that its contents shall be protected from the elements. It must be sheltered from the rain, and, if the young are to remain in it for any length of time, shaded from the sun. In taking these precautions the bird may be said to be simply following out the habits

W.L.C. 


\section{WILD LIFE AND THE CAMERA}

of its nature, so that it does come under the heading of that much-abused word "instinct." But at times birds are forced to resort to remarkable expedien ts thattheir eggs and young may be protected. Then it is that we see a display of what can only be termed intelligence : a careful weighing of existing conditions and formulating of plans to outwit enemies. One of the most common and at the same time the most interesting example of this is afforded by the way in which birds seek to rid themselves of the burden of fostering the cowbird's young. Much has been written on this subject, and yet people in general do not realise how clever the birds are. 'The accompanying set of photographs made directly from nature may help the reader to appreciate the truth of the following account of how a red-eyed vireo rid herself of a cowbird's spurious egg. The cowbird, like the European cuckoo, is parasitic in her habits, that is to say, she relies on other birds to incubate her eggs and watch over and feed her young. And it is quite customary to condemn the poor cowbird for such behaviour, no thought being given to the reason why. Everything in nature has a reason, if we would but stop to inquire into it, and anything so far from the natural order of things as a highly developed creature refusing to care for its own young must, without doubt, have a very strong and sufficient reason. Presumably the cowbird cannot lay her eggs on consecutive days, four or five days being, I believe, the interval between layings. Now it stands to reason that if she built her own nest and laid, let us say, three or four eggs, the 


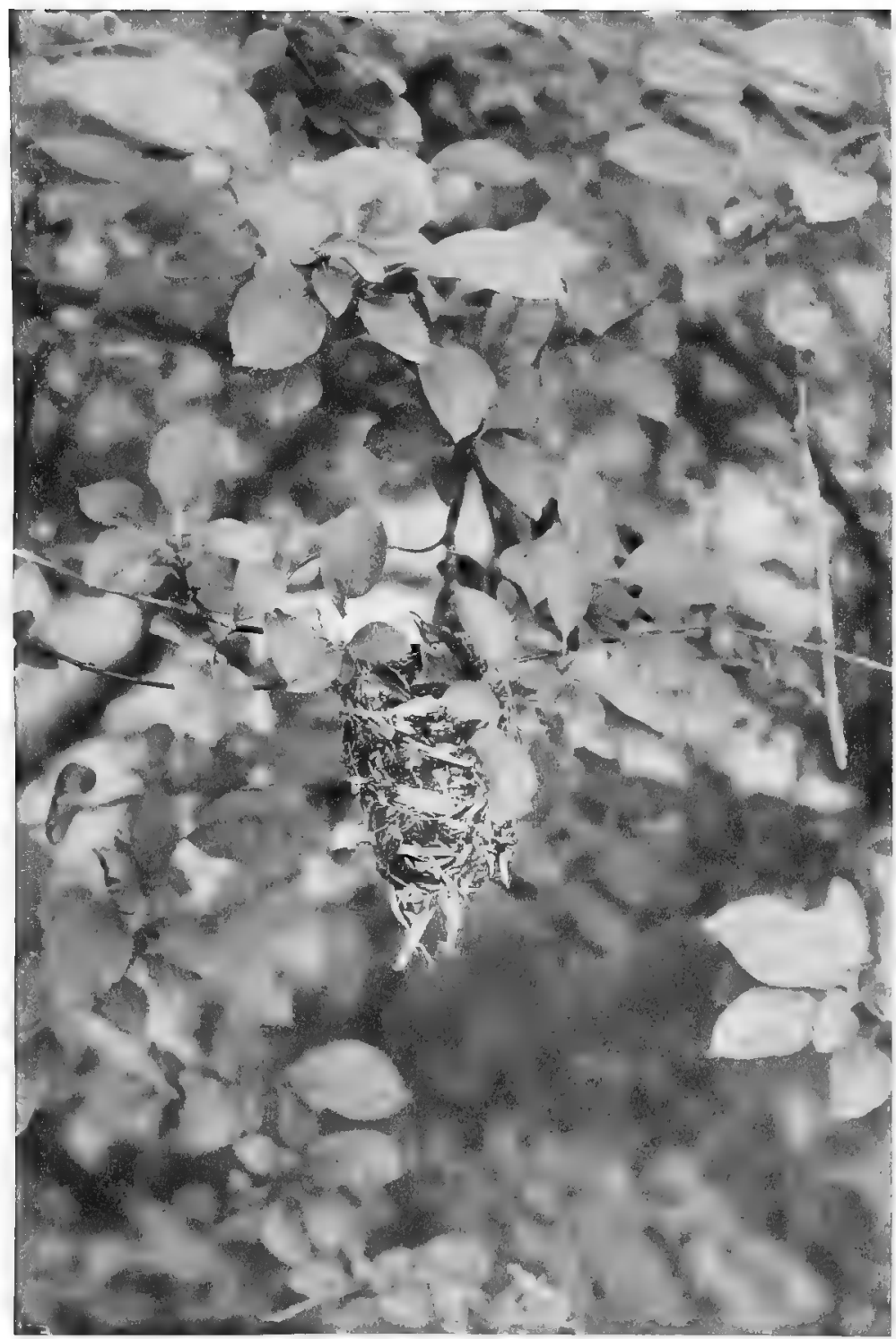

A White-eyed Tireo, whose lesirr for mrnamentation lerl her to cond her heautifil $\rightarrow$ min-pensle Nont with mall pieces of Woud that had been cut by it Woud-pecker. 



\section{THE VIREO AND THE COWBIRD 131}

first egg might spoil before the last one was laid. So the families would be very small, and the inevitable result would be a speedy extermination of this useful bird. To avoid this, the bird lays her eggs in the nests of other birds, usually choosing the homes of birds rather smaller than herself, so that her young shall be under no disadvantage in point of size. Sometimes she deposits her egg in the nest before the rightful owner has commenced laying. In such cases they are seldom allowed to hatch, but more often the cowbird watches her opportunity and places her eggs in a nest that already contains one or more. Then it is hatched with the others, and the young cowbird, being nearly always larger than his companion nestlings, manages to secure the greater share of the food and thrives accordingly, while the rightful owners sometimes die (so I am told) in the nest, or are forced out of it to die on the ground. All this is done by the cowbird in self-defence, and we should hesitate before condemning the bird for its seemingly strange behaviour.

A few years ago I had an opportunity of watching a pair of red-eyed vireos who had selected a tree near our house for their nesting site. The nest I had watched from its very beginning-a few beakfuls of dry grass and fine bark woven about the fork of a horizontal branch. Day by day the nest grew until after five days the beautiful semi-pensile structure was complete. It was a simple basket-like nest, supported by its upper edges being led to the forked branch. There was no attempt at decoration of any kind such as we 


\section{WILD LIFE AND THE CAMERA}

often find in similar nests, pieces of lichen, webs, cocoons, small pieces of broken wood, and such like substances, being fastened to the outside by means of webbing. On the day when the final touch was given, and the nest was in readiness to receive the first eggs, a cowbird came when the vireos were absent and deposited her grey speckled egg in the newly-finished nest; having done this she departed as silently as she came.

What were her thoughts as she thus silently deposited her precious burden in this strange cradle? How was she fulfilling this greatest of nature's laws, the perpetuation of her kind? Did she realise that there was some peculiar, and to our limited knowledge of things, apparently unnatural reason for not being able to take care of her own offspring? Why was she, of so many thousand species, selected to be denied the cares and joys of motherhood? Who can answer? Did she think at all on the subject as she searched the woods and fields for a suitable home for the young she would never see? Had she surreptitiously watched these vireos building their nest, knowing that when it was completed she would make use of it? Who shall say? Perhaps even it was all a matter of chance, though that is not according to nature's method. Had she suddenly realised that the moment was come when the egg must be deposited, and so chosen the first available nest from which the rightful owners were absent? None of these simple questions can we answer. Our surmises may be right or they may be wrong. We cannot know. Nature hides well her secrets, and so what are apparently the simplest 


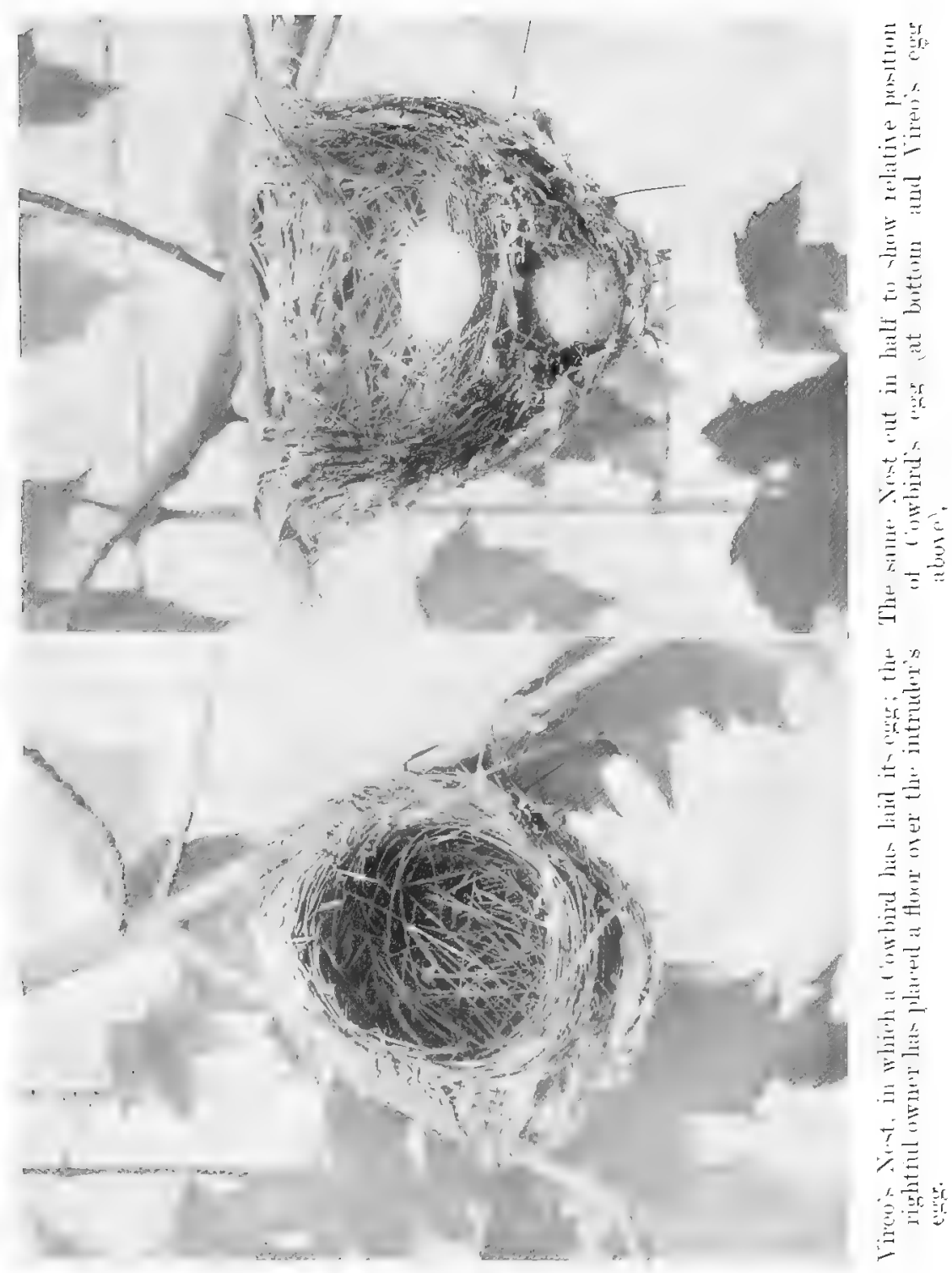




\section{'IHE VIREO AND THE COWBIRD 133}

problems must often prove on investigation to be the most difficult of solution. How often do we settle questions off hand and to our entire satisfaction, only to discover later on that our theories are utterly groundless and ridiculous? We have only our own experience on which to work, and so we endeavour to reason only from one point of view, forgetting too frequently that other creatures living under totally different conditions must base their actions on equally different premises.

When the vireos returned I was attracted by the noise they made, and, visiting the nest, discovered the cause of the disturbance. Such excitement there was, chattering and commotion. Now and then plaintive notes could be heard, as though they were bewailing their misfortune. Many other birds joined with them in their lamentations. The wood-thrush, whose nest was in the near-by maple, repeatedly uttered her loud single note of distress, as though in sympathy with the poor little vireos. But wherefore all this uproar? Why not cast out the spurious egg, destroy it, for, after all, had it any right to be there? Once more, who shall say? 'To us it would certainly seem far easier to throw it out. But, strange to say, that is seldom, if ever, done. Anything but that. Even let it hatch and allow the sturdy parasite to devour by far the greater share of the food brought by the industrious owners of the nest, so that the rightful occupants shall go hungry-yes, and even starve-for that often happens. But these vireos had no intention of letting the big, dull-coloured egg hatch. Soon the excitement died away and they fell to work 


\section{WILD LIFE AND THE CAMERA}

with a will, and in a few hours the unwelcome egg had almost vanished from sight.

It had been forced into the bottom of the nest, and a new floor was being laid over it. Nearly two days passed before the results were to the satisfaction of the imposed-upon birds, and then the mother bird laid one egg - a white egg with shell so thin that the yolk tinged it with a delicate pinkish hue; about its larger end were eight or nine tiny dark specks, which served to accentuate the purity of the white. 'The following morning the bird commenced incubating this solitary egg, and after the regular time had elapsed a small, helpless, pink bird took the place of the egg. Not having any others with whom to share its food it received more than usually falls to the lot of a young bird, and therefore grew with wonderful rapidity. In six days rows of pin feathers covered its fat little body ; in two more days these feathers had broken from their envelopes and partly covered the bare places. The youngster was evidently thinking of leaving his comfortable home, for I found him on the ninth day sitting on the edge of the nest taking in the general appearance of things. The next day he felt sufficient confidence in his strength to make his bow to the great world of trees, and sunshine, and caterpillars, and all other things that must be of interest to a fledgeling. By instinct he knew of enemies and would remain motionless in the presence of danger, trusting in his delicate pearly white and soft greenish-brown colours not to betray him to the enemy, human or otherwise. Instinct, too, told him how to fly, but 


\section{THE VIREO AND THE COWBIRD 135}

for the two or three weeks after leaving the nest he relied entirely on his parents for his food. They taught him what insects to eat and when and how to find them, how to look on the underside of a leaf for the small green caterpillars, how to dart quickly at any insect which had wings, and so many other things about which we know absolutely nothing. For there is much that a bird must know if he would win his way through life. Let him be slow to learn and his life will be a short one. For nature's law is, and always will be, "the survival of the fittest." 

NOTES ON THE BREEDING HABITS OF THE AMERICAN WOODCOCK 



\section{CHAP'IER IX}

NOTES ON THE BREEDING HABITS OF THE AMERICAN WOODCOCK

When the low damp swale has thawed and there is but little chance of another snowfall, the woodcock return from their winter quarters in the north to their breeding grounds of the previous year. As soon as the male bird has won a mate with his extraordinary system of courtship, which consists chiefly of spiral gyrations in mid-air, he, together with his chosen partner, at once examines the country for a favourable nesting site. This is an important matter, and the selection shows how the birds weigh the advantages of different likely places. There are several points to be considered: first of all, the actual site of the nest must be dry and in the immediate vicinity of a good feeding ground, but above all things must be considered the safety of the nest from the many enemies that threaten it. To insure this the clever birds depend not so much upon the dense tangle of underbrush, which one would naturally suppose to be the safest method of protection, as upon the colouring of the material with which the ground is strewn, for herein they show their reliance on their own protective colouring and marking which matches so nearly the dead leaves, weeds, and sticks. The reason that the nest is so seldom placed in the midst of a dense tangle 


\section{WILD LIFE AND THE CAMERA}

is presumably the desire for warmth from the sun. Every nest found by the writer has been situated so that during the greater part of the day it had the benefit of the sun's rays; but whether the warmth is desired by the bird itself or for her eggs, or in order that the ground immediately surrounding the nest should be kept dry, it would be difficult to say. As has been said, the colour of the bird is pre-eminently protective, so much so that even when we know within a few feet where she is sitting, it requires keen and observant eyes to discover her. Were it not for this fact the number of woodcock in the country would rapidly decrease, for their enemies are many. Boys would take the eggs, and the hawks, apparently numerous in the early spring, keep up such an incessant search that they would have little difficulty in detecting the sitting bird during this bleak season of the year. Few birds are more devoted to the cares of incubation, both the male and female taking part in that painfully patient duty, and it is seldom indeed that the eggs are left exposed to view. The coldness of the season may possibly have something to do with this, for the eggs would quickly spoil were they not kept constantly warm. When, however, it happens that the old bird is flushed, we notice how nature has provided for the safety of the eggs by tinting them with a drab colour freely blotched with dull brownish marks; thus is the egg rendered inconspicuous, as its colours blend to perfection with the immediate surroundings. The nest itself does not betray its precious burden, for in the strict sense of the word there is no nest, that is to say, none is built. 'The 


\section{HABITS OF AMERICAN WOODCOCK 141}

dead leaves are pressed down so that the eggs will have no tendency to roll away-perhaps some down or a few feathers are added and the nest is complete; simplicity itself, yet most admirably adapted to its purpose. In the vicinity of New York the eggs are laid about the first week in April, and as the period of incubation occupies eighteen days or thereabouts, it will be seen that the young arrive while the ground, which till so recently was covered with snow, is still naked, for the spring plants have not yet ventured from their mouldy cradles, so that protection must be found among the crackling dead leaves, and it is interesting to observe how very closely their colouring coincides with that of the dry leaves. Owing to the fact that the youngsters leave the nest almost immediately after they are hatched, we see how very important it is that they should be protectively coloured. Young woodcock obey the great law that governs fledgelings after they leave the nest, which says that when an enemy approaches no movement must be made. Sitting absolutely still, these little balls of russet fluff are safe from discovery, and even after the threatening danger has passed they remain motionless until a call from the parent bird informs them that there is no longer need of concealment.

How well the adult woodcock is protected by its markings and coloration is well indicated in the accompanying illustration, which is a faithful reproduction of a photograph taken directly from life. To insure accuracy as to colour values (which is, of course, a most important item, and one beyond the capacity of the ordinary plate to 


\section{WILD LIFE AND THE CAMERA}

deal with) isochromatic plates were used, together with a ray filter. So it is reasonable to suppose that the relative value of the birds' colouring and that of the leaves is faithfully shown. This and other photographs were taken on three consecutive days, and it is curious to note that in every case the bird had its bill beneath the twigs. This renders her even less conspicuous than she would otherwise have been. Her brilliant dark eye is almost the only thing that betrays her presence, even in the photograph, where she is sharply in focus, while the surroundings are more or less blurred. It has been said that if once a woodcock has been frightened from its nest by a person, it will not again allow of a human being's near approach, but will glide off silently while the intruder is yet many feet away. The bird here portrayed, though frightened (accidentally, of course) from her nest when first discovered, grew more and more tame and confiding with each successive visit, and finally allowed the camera to be placed within less than three feet of her. In order to show the position of the eye (which allows the bird to keep a sharp look-out even when its bill is deep in the damp earth, searching for worms) and the peculiar form of the head, the camera was placed about seven inches off the ground on two stones, brought there while the bird was sitting. Further than that, she allowed the writer's hand to come within three inches of her head and remove a twig which would have interfered with the picture. That the reader may fully realise how motionless the bird remained, it is only necessary to say that owing to the fact that 


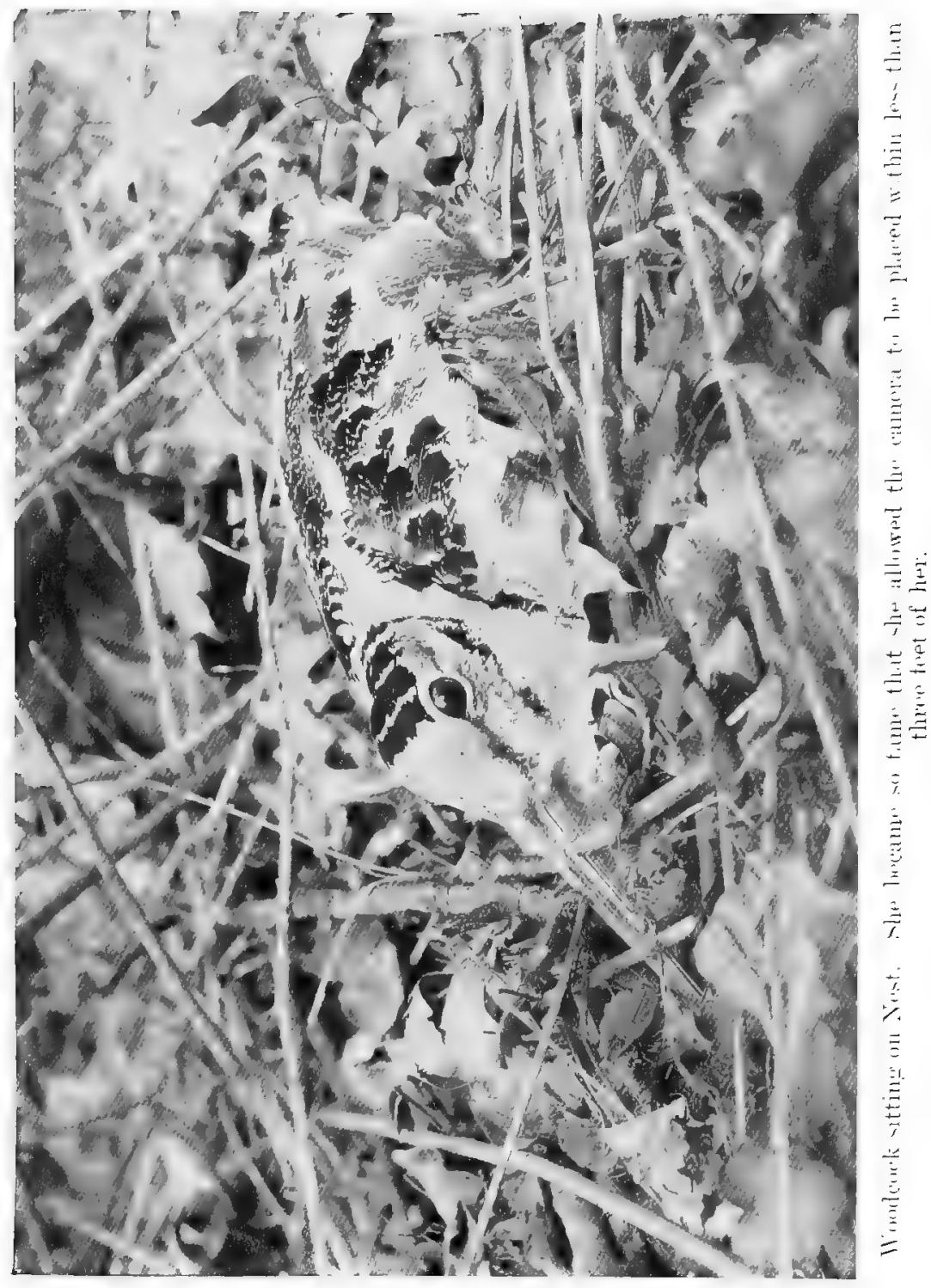




\section{HABITS OF AMERICAN WOODCOCK 143}

the photograph was made on a dark day during a shower, the ray filter (which trebles the length of exposure), and the smallest diaphragm were used, and that an exposure of ninety seconds was given. Yet there is no sign of movement. The question has been frequently asked, "Did she know that she was discovered?" It is probable that she did, for even with her knowledge of her protective coloration it is doubtful whether she carried her belief in it for quite such a length; but why did she sit so absolutely still? 



\section{SHOOTING WILD DUCKS AND GEESE WITH THE CAMERA}





\section{CHAPTER $\mathrm{X}$}

SHOOTING WIID DUCKS AND GEESE WITH THE CAMERA

THe clock in the big club-room had just struck eight, the hour when all the members and guests of the ... Shooting Club were wont to foregather and draw for blinds and men to pole their canoes. On the selection of a good blind must usually depend the day's sport, and a satisfactory man adds not a little to one's comfort and pleasure. As a guest I was to draw in my turn, when one of the members remarked that " any blind would be good enough for me, as I was only going to photograph, while the others intended to shoot."

This was the point of view of probably most of the veteran sportsmen present. They failed to see how it mattered whether I had opportunities to photograph the ducks or not, while it was of the utmost importance that those who used the gun should have the surest chance of killing the limit. I do not mention this as a criticism, but simply to show how little idea these men had of the sporting possibilities which the camera offers to the hunter. For to hunt with a camera requires infinitely more skill than shooting with a gun, and the number of successful photographic shots must inevitably be very much smaller. A keenness and alertness undreamed of by those who shoot is absolutely 


\section{WILD LIFE AND THE CAMERA}

necessary, and even then only under the most favourable conditions can one hope to secure satisfactory results.

Generally speaking, ducks decoy well only on overcast days, and in the early morning and late evening, when, of course, photographing is out of the question. The brightest light is none too good for making exposures of from one to two thousandths of a second, and anything slower than that will not catch the rapid action of a duck in flight. So it will be seen that in my form of hunting $I$ at least wanted as good a chance as the other sportsmen, and after I had explained my point of view I was allowed to draw a blind.

The following morning, just as the sun was creeping over the mist-hidden tops of the cypress trees, we started. My man seemed amused at my photographic battery, and evidently looked on me as a mild lunatic. Why I carried no gun was beyond his power of comprehension, and he poled the flatbottomed canoe through the sluggish Arkansas stream in a listless way which revealed more eloquently than words his utter contempt of my dea of sport. The other canoes passed us, and the men in them jokingly taunted my unhappy negro. Long years of experience with unenthusiastic guides had hardened my feelings, and I was no longer sensitive to anyone's ideas regarding camera hunting.

Eventually we arrived at our blind and put out the decoys, both live and wooden ones, and then I made ready for work by clearing a small opening in the brush through which I could operate the camera. This is a very important thing to do 
properly. Many a good opportunity may be lost through the intervening of a small twig between the lens and the birds.

Our blind was between two cypress trees at the edge of a swamp facing a large lake. For several hours we remained quiet, the only interruption being the snores of the guide, who lay fast asleep in the bottom of the boat. Several times ducks passed us, but always out of range, anything over a hundred feet being practically too far for the camera, even with a long-focus lens.

At last a slight splashing among the cypresses attracted my attention. There, swimming along not sixty yards away, was a solitary goose. Unfortunately I had not counted on anything in that direction, and therefore had not prepared a peephole; so I stood up, hoping to be able to get the camera above the brush. Quiet as I was, the bird heard me and immediately swam away, much to my disgust.

About half-an-hour later, while watching a pair of pintails that seemed inclined to come our way, with the corner of my eye I caught sight of something moving quite close to the blind. My surprise may be imagined when I say that this something proved to be the goose, not ten feet away. Here was the chance of a lifetime, and with trembling fingers I drew the slide from the plate-holder so as to be ready when the bird should pass the place where I had made the opening in the blind. At that moment the wretched guide moved his foot and made just enough noise to alarm the goose, and off it flew, without giving me a chance to 


\section{WILD LIFE AND THE CAMERA}

photograph it, owing to the intervening brush. No words can express my disappointment, for probably never again shall $\mathrm{I}$ have another opportunity to photograph a goose at such a close range.

I was mentally cursing my luck when Dame Fortune smiled on me, and I forgave her the trick she had just played. A pair of mallard drakes flew past, stooping to the decoys, then rising again, and after whirling around three times they finally dropped just beyond the decoys, perhaps fifty feet away. They were suspicious, and after sitting still for a few moments began swimming away. I quickly whispered to the guide, who had awakened, telling him to make a sudden noise, while I trained the camera on them. Up they flew, and I pressed the button just in time to secure the photograph shown in the frontispiece-by far the most satisfactory duck photograph I had ever made.

All that day and for nearly a week I worked hard at sitting still in a blind, but for some reason the ducks were not flying, except in the late evening, so I had no luck at all. Occasionally, to vary the monotony, we would take a trip across the lake, in the middle of which the geese were gathered in large flocks. By bearing down on them with a fresh breeze we sometimes were able to approach within about 150 yards, and as the birds had to rise against the wind they were compelled to come toward us. In this way I secured some fairly satisfactory shots at reasonable distances.

Not having enough material in the way of illustrations to complete this article, $I$ next decided to try a trip to Montauk Point, Long Island, where 
I had heard geese were very plentiful. Plentiful they were, but extremely wild. I tried many ways of getting within range of them, and eventually came to the conclusion that geese knew more than most people. They can see better than any hawk, can hear better than the most timid deer, have patience compared with which Job's was nothing, and, finally, have a system of communication more wonderful than wireless telegraphy. Altogether, I can take off my hat to the Canada goose and frankly acknowledge that nine times out of ten he can make a fool of me. For, truth to tell, my pride was so humbled after a second trip to Montauk that I felt positively flattered if my friends called me a goose.

Some of my most satisfactory attempts at securing photographs were obtained by driving in a carriage to within camera-shot of the geese. Like many birds that are afraid of man, the goose has less fear of him when he is in a carriage than in any other place. I have driven fairly close to the great bustard in Russia when stalking them on foot was practically impossible; in the same way hawks may be approached in a carriage better than in any other way. 'The great objection to this method, so far as geese were concerned, lay in the fact that frequently the carriage could not go near the places where the geese were.

Sometimes I tried having them driven over me, and this gave me several good chances. But only in one or two places could this be done with any degree of certainty.

Stalking in most cases proved impossible. Try 


\section{WILD LIFE AND THE CAMERA}

as I might to conceal myself, there was nearly always a bird in some unexpected place that would get his eye on me and immediately inform every goose in the lake that a fool man was crawling on his stomach among the sand dunes with the apparent intention of doing harm. Meanwhile I, completely ignorant of the fact that a spy had given away my plans, would continue crawling laboriously through the sand and briars and scrubby brush, not daring so much as to raise my head above the cover until the place was reached where I had seen the geese. With hope in my heartand hope is really the chief asset of the camera hunter-I would open my camera, and with everything ready for instant action quickly rise, only to find before me a beautiful view of blue water and sand dunes, while far away in the middle of the lake my geese sat quietly chuckling to each other as they saw how I had been outwitted. An hour's hard work had gone for nothing, and as I emptied the sand from my shoes and pockets, I thought very unprintable things about geese in general and about those geese in particular.

My efforts at baiting with corn proved only fairly satisfactory, except to the crows, which ate most of it. Forr three days I sat crouched in a clump of low bushes while my bones ached, and I watched geese. Once they came within a hundred yards and then turned away because a crow flew over my head, and, seeing me, called out to the geese that a man was there. In this way he drove them away and had the corn to himself-truly a case of disinterested friendship! Another day I 

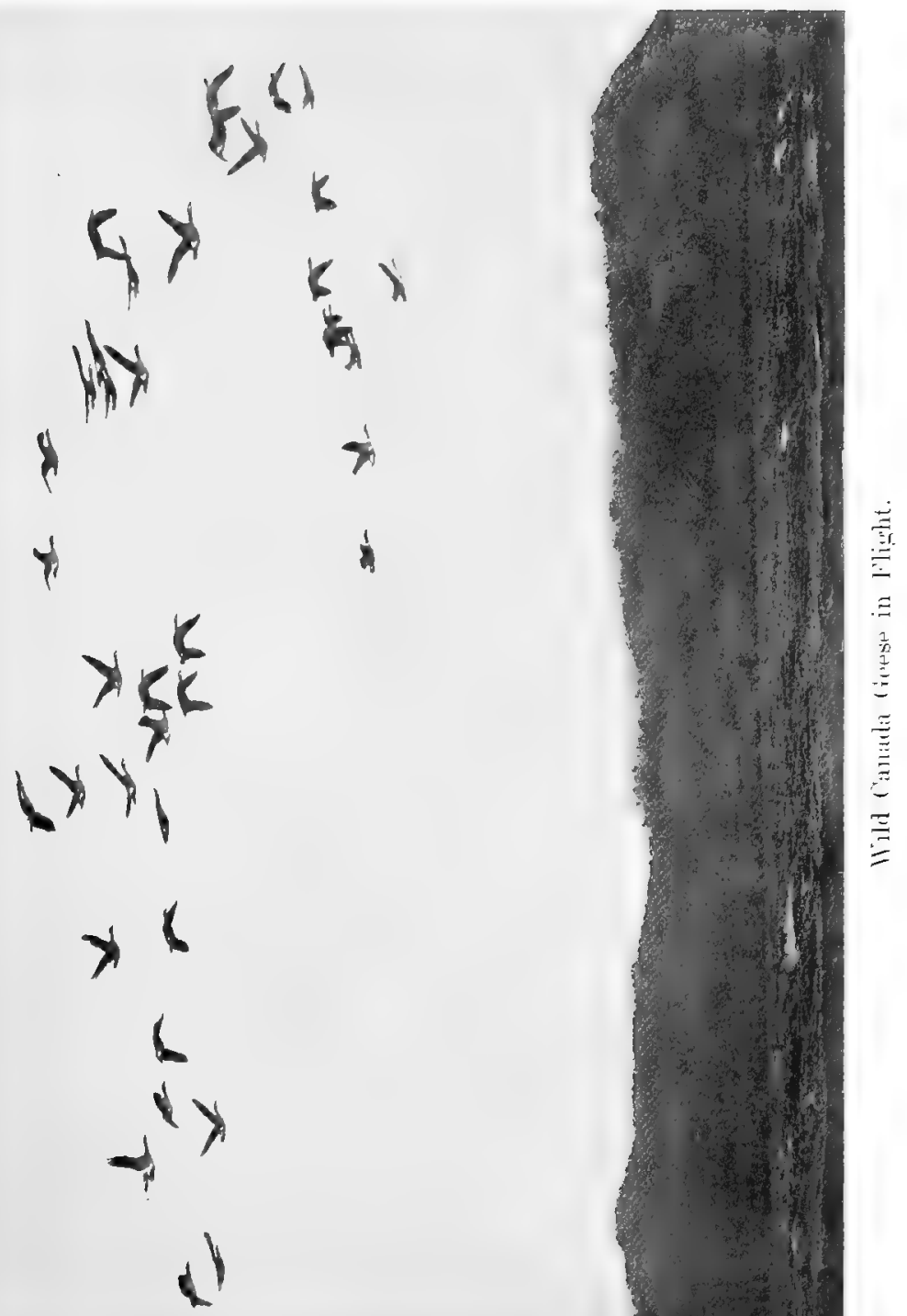



\section{WILD DUCKS AND GEESE 153}

watched about forty geese for several hours as they fed and played scarcely two hundred yards away. All this time the sun was shining brightly. At noon it clouded over, and an hour later the rain fell in torrents. Then, of course, those exasperating birds came to the bait and fed not forty yards away. It was too dark, however, to make a satisfactory photograph as they flew away. I would have made a picture of them feeding, but no one would have believed that they were wild geese.

For photographing such quick birds as ducks and geese it is, needless to say, absolutely necessary to use a very rapid shutter and a long-focus lens. The telephoto is not very satisfactory, owing to its lack of speed, so it is better to be content with a smaller image and enlarge the negative, as I have done with all the accompanying illustrations, some of which have been enlarged over eight diameters. 

THE WHISTLING SWAN OF CURRITUCK SOUND 



\section{CHAPTER XI}

THE WHISTLING SWAN OF CURRITUCK SOUND

The mention of the name swan brings to our mind pictures of well-kept lakes or ponds surrounded by ornamental shrubs and stately buildings. "Among our ancestors, too simple or too wise to fill their gardens with the frigid beauties of art instead of the lively beauties of nature, the swans formed the ornament of every piece of water." In literature, painting, sculpture, mythology, and history these graceful birds have been used more, perhaps, than any other feathered creature. They have been made to typify grace, beauty, love, passion, domesticity, peacefulness, and courage. That swans actually exist in a wild state seems, curiously enough, to be almost incredible to most people, yet not only do they exist but they are, comparatively speaking, abundant; and strange to say, unlike so many birds, they appear to be even gaining in numbers, or at least holding their own.

Unfortunately, they are not widely distributed, and any one who would enjoy the remarkable sight of hundreds of them must go to their habitual winter resorts. Along the Atlantic coast a few are seen on the eastern end of Long Island, while great flocks congregate in the brackish waters of Currituck Sound, North Carolina.

When the cold winds from the north warn us 


\section{WILD LIFE AND THE CAMERA}

of the coming of winter-that is to say, about the middle of November-the swans begin to arrive from their breeding grounds in the Arctic region. Flock follows flock, until the dancing waters of the Sound sparkle with their snow-white plumage, and the air is filled with their soft musical notes. It is hard indeed to imagine a more beautiful picture than a large flock of these graceful creatures lined up close together, looking in the distance almost like snow-covered drift ice, and then to see them rise. At last we can appreciate their size as their great wings unfold and noisily strike the air with powerful strokes in the effort to carry the immense twenty-pound bodies clear of the water. On a calm day they rise with difficulty, using the feet to gain momentum, and often covering a distance of seventy-five feet or more before leaving the water. With a fairly good breeze, however, they lift themselves with astonishing rapidity by heading directly into the wind. In watching them start it does not strike the observer that they move quickly, and in attempting to photograph them I could scarcely bring myself to make the exposure short enough to ensure a really sharp picture. The fact that they did move rapidly was very evident when I saw the birds on the focussing glass, for it seemed almost impossible to keep them there, and the camera had to be swung as though it were a shotgun trained on a flight of wind-driven ducks.

Once the swans are fairly under way their speed is amazing-nearly a hundred miles an hour, and that, too, with no apparent effort, for the slow wing motion is very deceiving. Their endurance is as 


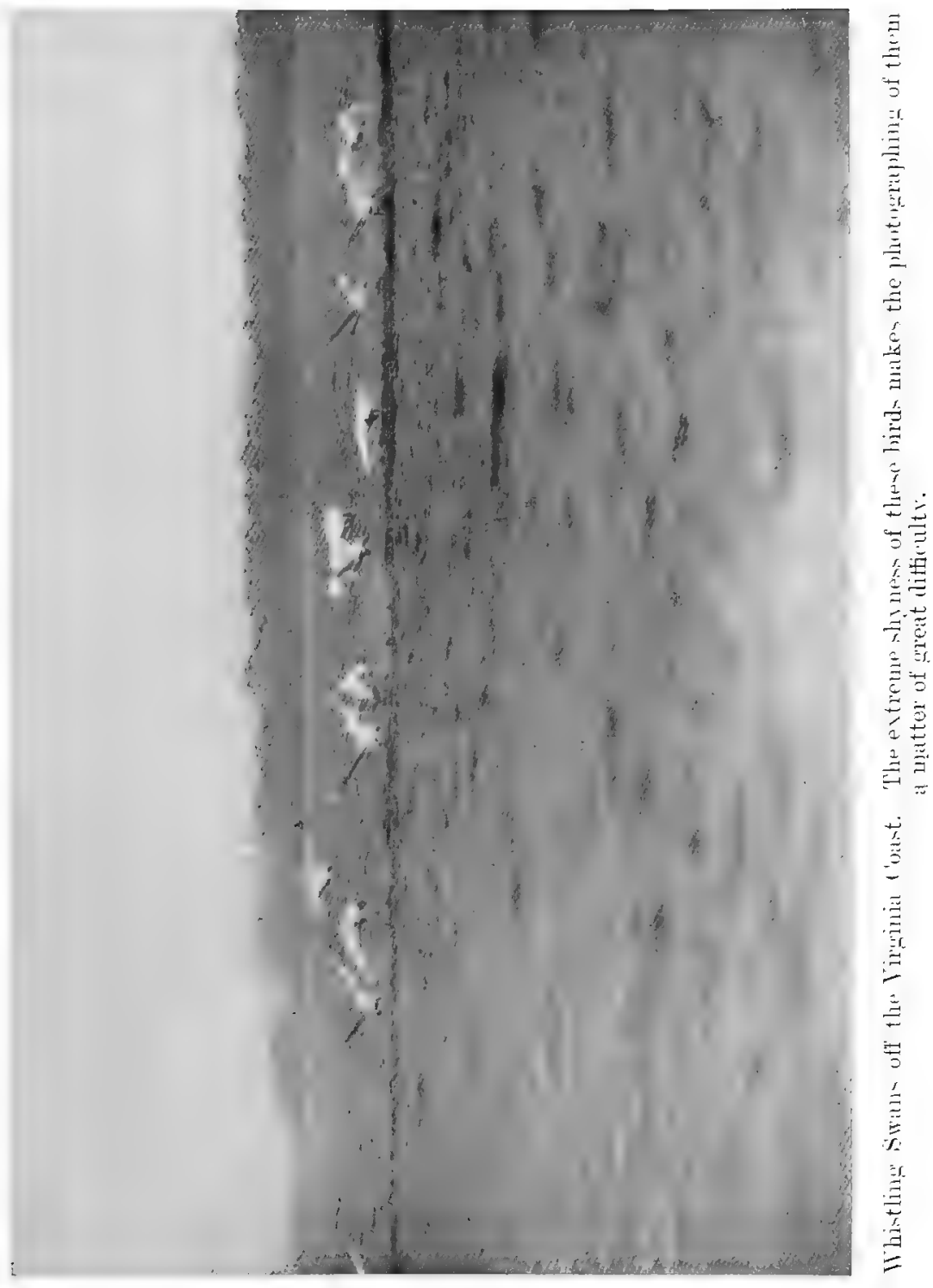





\section{SWAN OF CURRITUCK SOUND 159}

surprising as their speed, for they are said to travel a thousand miles without alighting.

When making these long journeys they fly high, so high indeed that they are often invisible to the naked eye. Yet on a still night you can distinctly hear the rhythmical singing noise of the long wings striking the air with force sufficient to drive the huge birds at a speed greater than that of the fastest express train.

The flocks are usually led by an old and experienced swan, and it is said that as one becomes tired of leading, or it might be called aerial trailbreaking, his place is taken by another whose strength is equal to the task, and so they continue until they reach their destination, the southern feeding grounds of the winter or the northern breeding places of the summer. Occasionally they stop to rest in the region of the Great Lakes. Not many years ago, while on their way north, a large number stopped above Niagara Falls, and more than a hundred were, by some extraordinary mischance, carried over the falls and killed in the surging waters.

Whether the swans prepare in any special way for their southward journey is not known, but before starting north they indulge in the curious habit known as "ballasting" - that is to say, they eat great quantities of sand, for what purpose no one knows.

In the far away Arctic Ocean is their breeding place, and it is believed that they mate for life. Their nests, which are placed on the ground, are of immense size, fully six feet long and two feet 


\section{WILD LIFE AND THE CAMERA}

high, and made of sticks, weeds, and rubbish. As with so many of the water birds, the swans protect their eggs with a covering of down scratched from their own breasts, so that, when the birds leave the nest, the two to six large, yellowish eggs are hidden from the eyes of possible thieves, and protected against any sudden changes of temperature.

It is many years before the swans are clothed in the feathers of immaculate whiteness which make them such conspicuous objects of beauty. Not indeed until the fifth year does all trace of grey disappear. Their first feathers are entirely grey; gradually they lighten, becoming mottled with white, the neck and head remaining grey until after the body is completely white. The bill, so conspicuously black in the mature bird, goes through many changes, being almost white the second year, the black appearing a year later. In the common American or "whistling" swan there is a small oblong spot of bright yellow on the naked skin just forward of and below the eye, whereas the "trumpeter" or Western species is entirely black from the eye to the tip of the bill.

Neither of these varieties is the swan of the poets or garden ponds. These are a European species which are even more graceful than our wild ones. Perhaps the most conspicuous difference in the appearance of the two birds is in the form of the neck, which the American swan holds straight instead of in the graceful curve so noticeable in the tame bird.

It is impossible for one who has seen only the 


\section{SWAN OF CURRITUCK SOUND 161}

common mute swans floating about in the artificial lakes of our city parks to imagine the grandeur of a flock of the great whistlers in their wild state. As the huge birds rise into the air it seems as if an aerial regatta were being sailed overhead, the swans, each with a wing spread of six or seven feet, moving like yachts under full sail. The sight is one of the most impressive in nature.

During the winter months swans may usually be seen in company with immense numbers of Canada geese, and often with ducks of several species.

Like many of their smaller relatives, swans usually fly in wedge-shaped flocks, especially when migrating. The habits of geese and swans are more or less similar, grass and roots being their chief food, but one rarely sees a swan tipping after the manner of the river ducks, and never diving. On windy days the flocks separate, the geese going under the shelter of the land, while for some reason the swans prefer a lee shore.

Fortunately sportsmen have never seriously regarded the swan as a game bird to any great extent, though it is true that they shoot them when opportunity occurs. Their wildness, however, almost prohibits stalking them, though if it were allowed (and fortunately at present it is not) they might occasionally be shot from fast launches. Perhaps the greatest safeguard is in the fact that rifle shooting is prohibited, at least nominally. As an article of food the swan does not appeal to most people-in fact only the younger birds, known as "blue swans," are fit to eat. So on this account they do not suffer from that greatest of all enemies w.L.c. 


\section{WILD LIFE AND THE CAMERA}

to birds-the "market hunter," the man whose wholesale slaughter of our wild creatures is a disgrace to the country. Legitimate shooting by honest sportsmen will never do much harm; we might even say that the sportsman is the best friend the bird has, for to him is due the passing of sensible laws which really protect birds. Then, too, the sportsman sometimes replenishes the stock of birds, or at least takes pains to protect them during the breeding time, while the market hunter simply destroys.

Down in Currituck nothing is thought of a single boat bringing in over a hundred ducks of one species as a result of a day's injurious workwork made still more injurious and deadly since the introduction of the unsportsmanlike slaughter machine, the "pump" gun. If this ghastly business is to be allowed it will be but a very short time before our game birds will exist only as a memory. The one way to protect with any degree of success is to prohibit absolutely all sale of native wild creatures, birds as well as animals.

Unfortunately, there is not space here to go into this subject, scarcely even to touch upon it, but we cannot help wondering what would become of the noble swan should public taste ever demand it as an article of food. How long before it would be driven from our coast to join the ranks of the departed buffalo? If only the people would throw off the cloak of apathy and force their representatives to pay heed to the warnings of the few (too few, alas !) men and women who have given thought to the subject of bird preservation, so that decent 


\section{SWAN OF CURRITUCK SOUND 163}

laws might be passed and the birds given the protection they so greatly need! This is a subject which should interest everyone, whether sportsman or not, for without the birds how much we should lose in our enjoyment of life in the country! 


\section{TWO 'POSSUMS AND SEVERAL MISTAKES}


' 


\section{CHAPTER XII}

TWO 'POSSUMS AND SEVERAL MISTAKES

Two 'possums each made mistakes, with the result that they both got themselves into many kinds of trouble, with almost tragic consequences.

As we know, 'possums, like owls, usually travel only by the light of the moon, the stars, or by no light at all. When all the world is hushed in sleep, hen roosts are much easier to rob, for except the cackling of a hen-and even that should not happen if the job is neatly done-there need be no noise or fuss of any kind. Even the watch-dog, keen-eared as he is, may sleep on oblivious of all that the 'possums are doing within his precinct. But, as already stated, the two 'possums with which we are dealing made mistakes, and the first of these mistakes was neither more nor less than that they came out by daylight. The day was dull and grey, it is true, but none the less it was day, and therefore not the time for 'possums to be out.

'Possum One (as we will call him), who had selected a temporary home in a drain-pipe only the night before, had been disturbed, because some thoughtless man had turned a flood of water into his pipe home and had given him a most unwelcome bath. So he determined, force of circumstances urging the determination, to make for a certain large gum tree, whose branches overhung the 


\section{WILD LIFE AND THE CAMERA}

muddy waters of the Passaic River. In this tree was his regular nest. A comfortable one it was, too-quantities of dead dry leaves placed in a hole in the trunk about ten feet from the ground. The hole faced towards the south, so that when the sun shone he had the benefit of its warmth. Curled up in this hole, covered with leaves, some muskrat fur and chicken feathers (whence came those feathers, Mr. 'Possum?), he had spent all last winter. When all around him was wrapped in winter's white winding-sheet, the snow had piled up over the entrance of his home, but the warmth of his body had melted it away and left his doorway clear.

Now it was autumn, late November, and all was cold and dreary. The leaves, with which the ground was so thickly strewn, rustled loudly as he shuffled along towards his gum tree. Arriving there he stopped, for a suspicious odour greeted him, the unmistakable proof that but recently another 'possum had been there. The invisible trail led up the tree. Worse and worse! Bad enough to have anyone come to his tree, but to climb up looked suspiciously as though the stranger had pre-empted his own home. Now came the question: What could he do if this stranger happened to be larger than he was? Would he have to give up his home, and that, too, without a struggle? Or should he try to coax him out? Better first investigate. So up the tree he went, after the slow, clumsy method of his kind, until he reached his doorstep, and then -well, he slid down again, just a few feet, and all because a long-pointed nose protruded from the 


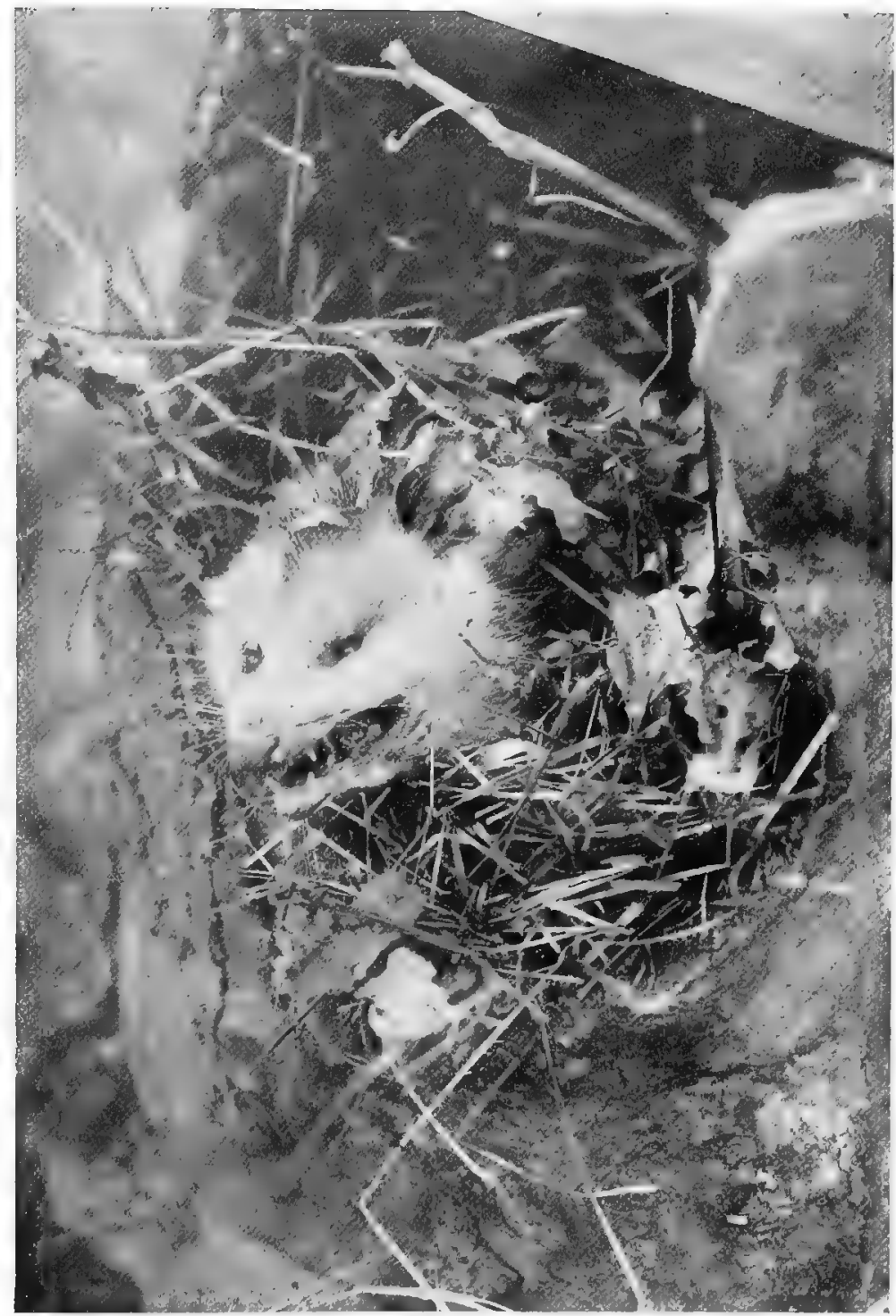

"A long nuse potruled from the nent." 


$$
\text { , }
$$


nest of leaves and feathers, and the nose was followed in turn by an open, well-toothed mouth and a quite unnecessary amount of snarling, of that quiet guttural kind that 'possums delight in.

'Possum One cared not to risk an encounter with one so much larger than himself, and so ill-tempered too. It was better to wait a short time, just to let his amiable tenant see that he was not afraid. Oh dear, no! Never even thought of such a thing! Then, to show how entirely friendly was his visit, he wished to know if 'Possum Two would care to join him in a walk to the hen-house. It was only a short distance away, and as it was late in the afternoon he felt sure the chickens would be home, and even if they were not, they could hide and wait until they did return. All this was said in the same sort of language that a dog uses when he comes into a room where another dog is lying, and asks him what he thinks of going off for a hunt; and off they go, one at a time, so as not to attract attention until clear of the house. So went our 'possums. In the lead was 'Possum One, with 'Possum Two following a few yards behind. Up the lane they went, keeping careful lookout. When halfway along they saw a man coming their way, so they quickly (and 'possums can do things quickly) crept in between the stones of the wall that edged the lane. Their enemy having passed, they came out cautiously and once more resumed their way to the farmyard. On arriving there 'Possum One went ahead, on past the corn-stack and the stables, past the corn-crib and towards the small hen-house. Everything seemed quiet and 


\section{WILD LIFE AND THE CAMERA}

therefore safe, and soon he saw 'Possum Two, who had crept along the fence, standing on the top of the hen-house. Then the two would-be thieves entered, one by the window and the other by the door, but the hen-house was empty of hens, so out came the two prowlers, disappointment showing in their dejected appearance. The shutting of a door in the farmhouse near by disturbed their peace of mind. 'Possum One, on coming out of the door, scrambled quickly on to the roof of the hen-house, while 'Possum Two remained in the window. Danger signals sounded loudly on the ground as a man came walking down the pathway. At this moment the 'possums made another mistake, for the man would probably have passed them unnoticed had they not both snarled, and thereby attracted his attention.

Now it happened that the man was not an American, and in that accidental fact lay the 'possums' one chance of escape. An American farmer would have picked up a fence rail and with it promptly ended the lives of the "darned little varmints," who, even though they were thieves, stole only that they might live. But the man was an Irishman, fresh from St. Patrick's Isle. He had never seen a 'possum, nor did he know anything of their peculiar ways. Only the 'week before, he had been engaged as a farm hand, and had been left on the place while the farmer and his sons had gone to the polls to vote, for the day was election day, hence the quietness of the farm which had inveigled our two marsupials from their retreats. 


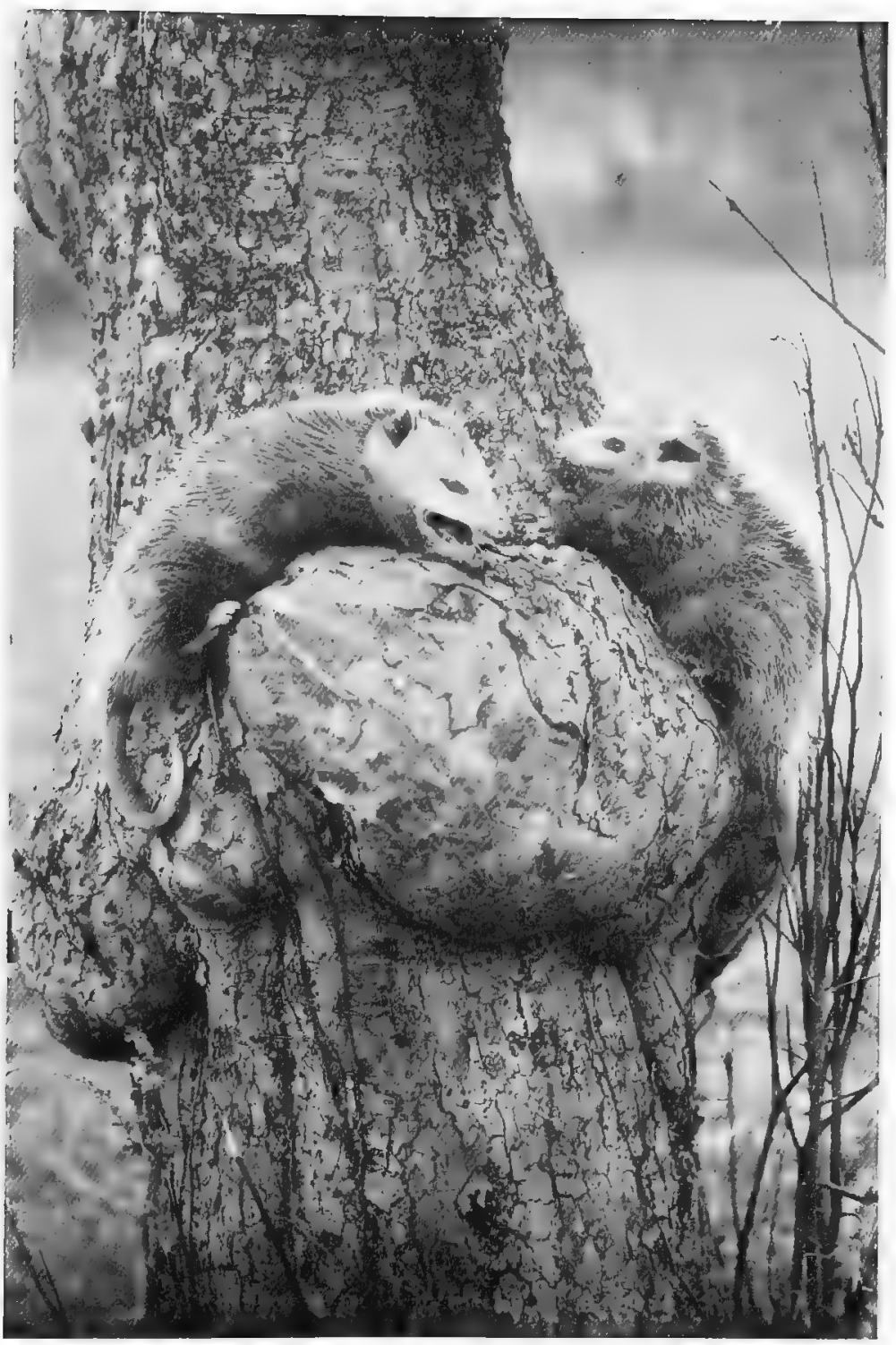

"Possums, "Nearer and nearer he came until his nose was visible ovtr" the edge of the large knob." 


\section{.}


Now when Dennis O'Connor saw the two strange beasts his surprise was very great, and after uttering a few remarks that are best left out of print-for, after all, they have nothing to do with the story-he turned, brave man though he was, and made straight for the house. He remembered having noticed a gun standing against the wall near the chimney-corner. With such a weapon he feared no animal under the size of a dog, and he hurried out to do battle against the small silverhaired animals. These same animals had been making the most of their time. No sooner was Dennis out of sight than they scurried along as fast as their short legs would carry them to the apple orchard. Once there, each one proceeded to climb an apple tree. 'Possum One in his hurry selected a tree so small that it afforded him no hiding-place, so he must perforce come down again, and that he did in the quickest possible time, clinging to the tree with his naked prehensile tail as he partly slid and partly climbed down. Once on the ground, he made directly for the nearest tree, which chanced to be the same tree that 'Possum 'Two had chosen. Here was still another to add to the growing list of mistakes, and like the proverbial drop that overflowed the equally proverbial bucket, it proved the undoing of their otherwise successful retreat.

One 'Possum might hide in an apple tree and remain undiscovered because of his colour, which matches the rough silver-grey bark of the tree very closely, but two 'possums could scarcely hope to find places of concealment in the same tree. So 


\section{WILD LIFE AND THE CAMERA}

thought 'Possum Two as he sat on a large knob that protruded from the side of the tree. He heard the scratching sounds of 'Possum One as he climbed the tree. Nearer and nearer he came, until his nose was visible over the edge of the large knob. What might have happened is not known. 'Possum 'Two's vigorous protesting at his friend's arrival was cut short by a loud report and a scattering of small pieces of bark where the shot had struck the tree just above the 'possums' heads. Scarcely had the echoes of the report died away when Dennis saw two 'possums fall to the ground at the foot of the apple tree, and he congratulated himself on "the foine shot" he had made, and forthwith marched up to the seemingly dead animals. "Shure, but they're did as nails," he exclaimed, as he picked up one in a most gingerly way, quickly dropping it again. Yet there was no blood visible, but in his excitement he had not noticed a detail so altogether trivial. Enough for him that the two animals were dead, and he himself was responsible for their slaughter, and he turned to lay down the gun that he might light his pipe, preparatory to carrying the animals back to the house. As he stood still trying to light his short clay pipe, his back was toward the 'possums. Everything was so quiet that 'Possum Two decided to have a look and, without changing his position, he opened his small, dark eyes, closing them instantly when he discovered the broad back of his enemy between him and the sky.

It was a close shave, for at that very moment Dennis, his pipe lighted, picked up the gun, and, catching hold of the two 'possums by their rat-like 


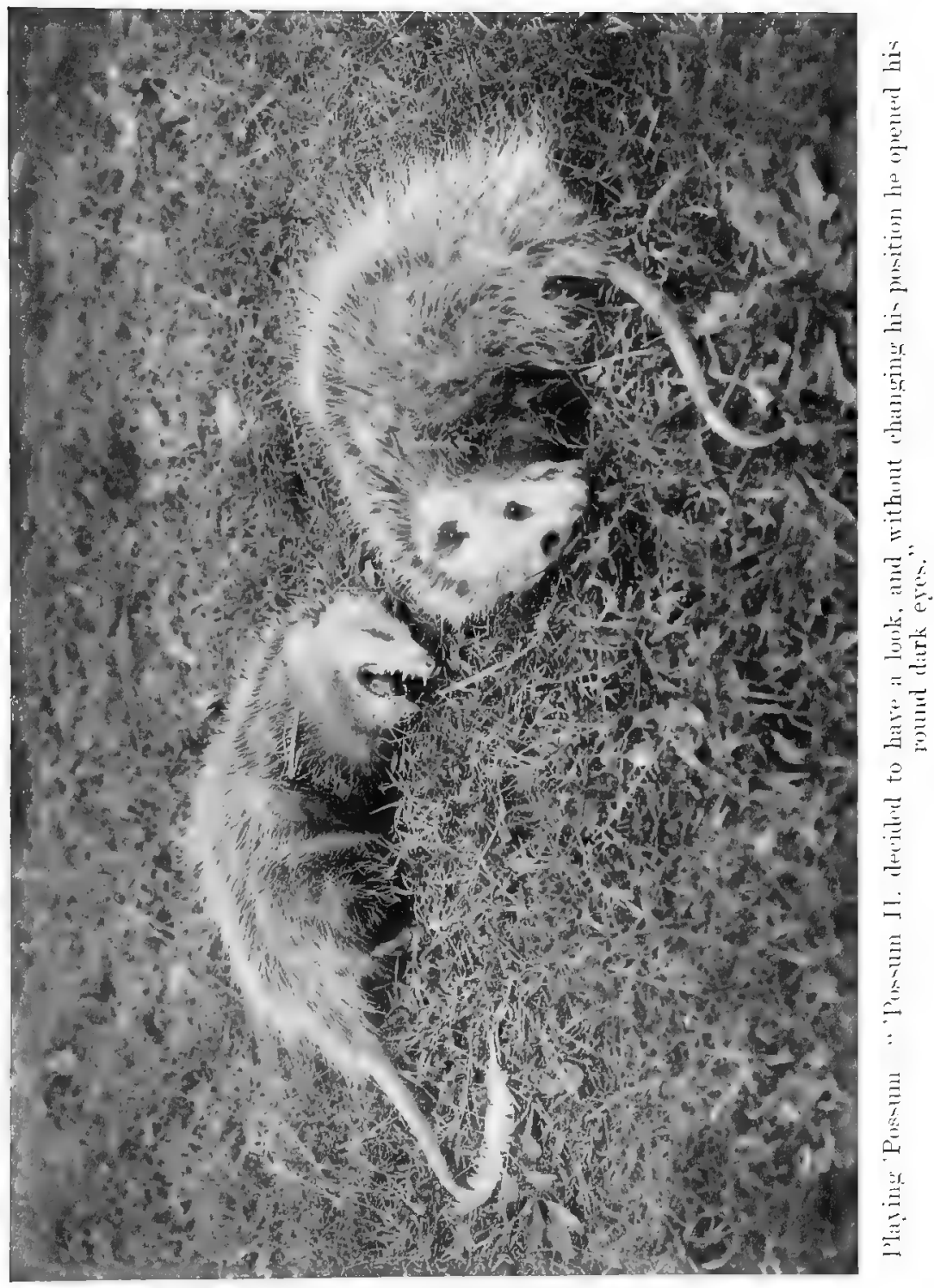


1 
tails, took his way to the house. Once there he threw the two "dead" animals on the steps, and leaving them he turned and walked toward the gate, for he heard sounds of the farmer returning. Round a bend in the lane came a two-seated buckboard, mud-bespattered and rickety, and in it sat the farmer and his boys. Dennis O'Connor, all excitement and pride, rushed up to them and told the family all about "the two queer bastes Oi hev kilt," adding quickly that he had killed "thim both wid the one shot from the fowlin" pace." On being asked what he had done with his game, he pointed exultingly to the clean, bare steps, but-—

It was many months before Dennis could be persuaded to give up his belief that someone had stolen his 'possums. He never saw them again, and the story of "playing 'possum" is, and always will be, a sore point with Dennis O'Connor. 



\section{A FISHING TRIP IN THE HIGH SIERRAS OF CALIFORNIA FOR GILBERT AND GOLDEN TROUT}





\section{CHAPTER XIII}

A FISHING TRIP IN THE HIGH SIERRAS OF CALIFORNIA FOR GILBERT AND GOLDEN TROUT

A TRIP across the continent to the Kern River and Volcano Creek, the home of the gilbert and the golden trout, was the genial task which fell to my lot this month of July, 1905. An alluring task to one who had never before been west and to whom fishing was the most fascinating of all sports. Much I had heard and read of the wonders of the High Sierras of California, the beauty of the scenery, the extraordinary climate and the never-failing abundance of fish. But though I had made up my mind as to the beauty of the country, I confess the preconceived idea fell far, very far short of the reality. To give any idea of the actual conditions is impossible, for who can describe this country and feel that he has done even the scantiest justice to his subject? Yet $\mathbf{I}$ feel that to ignore it were worse even than a most inadequate attempt at a description; to him who has not had the good fortune to visit this paradise, a few words offered with humble apologies may not prove amiss. Be he fisherman or merely a traveller in search of a wonderful outdoor trip, he must be equally impressed by what he sees in nature, especially in such a region as the Kern River. In fact, I often wonder whether fishing is much more than a happy

W.I.C. 


\section{WILD LIFE AND THE CAMERA}

excuse for being out in the open, out among the mountains, the streams and the innumerable delights which nature offers us with such a bountiful hand. If it were the fish alone we wanted, why leave the sea with its endless varieties of fish, big and small, gamey and sluggish? No stream offers such "catches," but so few get much real pleasure from simply hooking and pulling up fish.

The pleasure is largely in the surroundings. All our senses are thrilled and the blood dances in our veins; we listen to the sound of the bubbling water, a fitting accompaniment to the delicious music of the birds as they sing their love songs, or watch the busy little feathered housekeepers, some gathering material for their nests, others with hungry young at home, eagerly darting after the incautious insects that frequent the waterways. Along the banks are flowers nodding their heads to the passing breeze as they nestle among the rich green moss. Everything interests, for to the healthy man everything out of doors is beautiful, nowhere more so than along dancing rock-strewn streams, where life in so many forms is concentrated. 'The fish you may catch are an incident only, a delightful incident, which adds immeasurably to your satisfaction and pleasure and makes the day a complete success. It is well enough for the man who does not fish to say that he gets just as much fun out of a day's outing, that he can enjoy the birds and the flowers even more because his mind is not distracted. I doubt it. Complete pleasure is seldom obtained by one thing alone, it is more usually the blending of many, often totally different, sensations which 
constitutes a sensation of perfect pleasure. The fisherman frequently, without realising it, blends many subtle sensations; he caters to many senses, and the result is bliss, often absolute bliss and satisfaction which make him the most patient, persevering man on earth, even while at times they unfortunately render him utterly selfish.

But I am wandering from my subject and had better abandon the attempt to analyse the philosophy of angling, and return with equal futility to attempt describing the beauty of the High Sierras. Let the reader come with me and we will enter the country together. Quickly we will pass over the long, dusty drive from Visalia, during which the heat parches the skin and renders the tongue dry and leathery, along the road of no shade, where a man who would rest must find the slim shadow of a slender telegraph pole to shelter his spine from the scorching rays of the sun. A few hours and it is past. We reach the foot-hills, where there is vegetation and shade. In the last golden light of the setting sun we reach our destination, a small inn, where we put up for the night and where we find our pack mules and saddlehorses awaiting us according to instructions. Everything is made ready for an early morning start, for we shall have to travel some forty miles or more if we would halve the distance to the Kern River. Long before dawn we are up, and after a hasty breakfast the balky mules are safely loaded with our simple outfit: food, fishing tackle, cameras and warm blankets, and that is all. While the valley below is still slumbering in the purple haze of early 


\section{WILD LIFE AND THE CAMERA}

morn we start along the upward trail. Soon the sun rises and the heat makes us long for the higher altitudes. Our way is through fairly open country, dry as powder, and clothed with wild oats and yellowish grasses, scattered dry oaks and other greyish green trees, giving the country the appearance of a dried park, for nowhere except near water is there any green. Down in a partly dry river bed, which gleams intensely white in the glare of the sun, we see a huge log stranded among the smooth boulders. This log, about sixteen feet in diameter, we are told, is part of a redwood tree. It has lain in this river-bed no man can say how many years. Then we realise that above there is much to be seen, and we may yet ride through the worldfamous forests of the sequoia or big tree.

Gradually the country changes, vegetation becomes more abundant and varied, and as we go higher the colour is greener and more pleasing and restful to the eyes. On we go ever upward, along narrow, steep trails overhung with shrubbery, through dense thickets of syringa and white lilac, whose fragrance is almost overpowering. Later on the sun drops to the westward; we reach the conifer forests; immense spruces and firs, with here and there a small cluster of diminutive redwoods, small of their kind but nearly 200 feet high, lifting their thinly-leafed tops high above all surrounding trees. Flowers become abundant-the exquisite mariposa lily, lupins of many colours; but we are not yet in the land of flowers. Evening overtakes us as we reach the expected camp ground, and the selection of a camp 


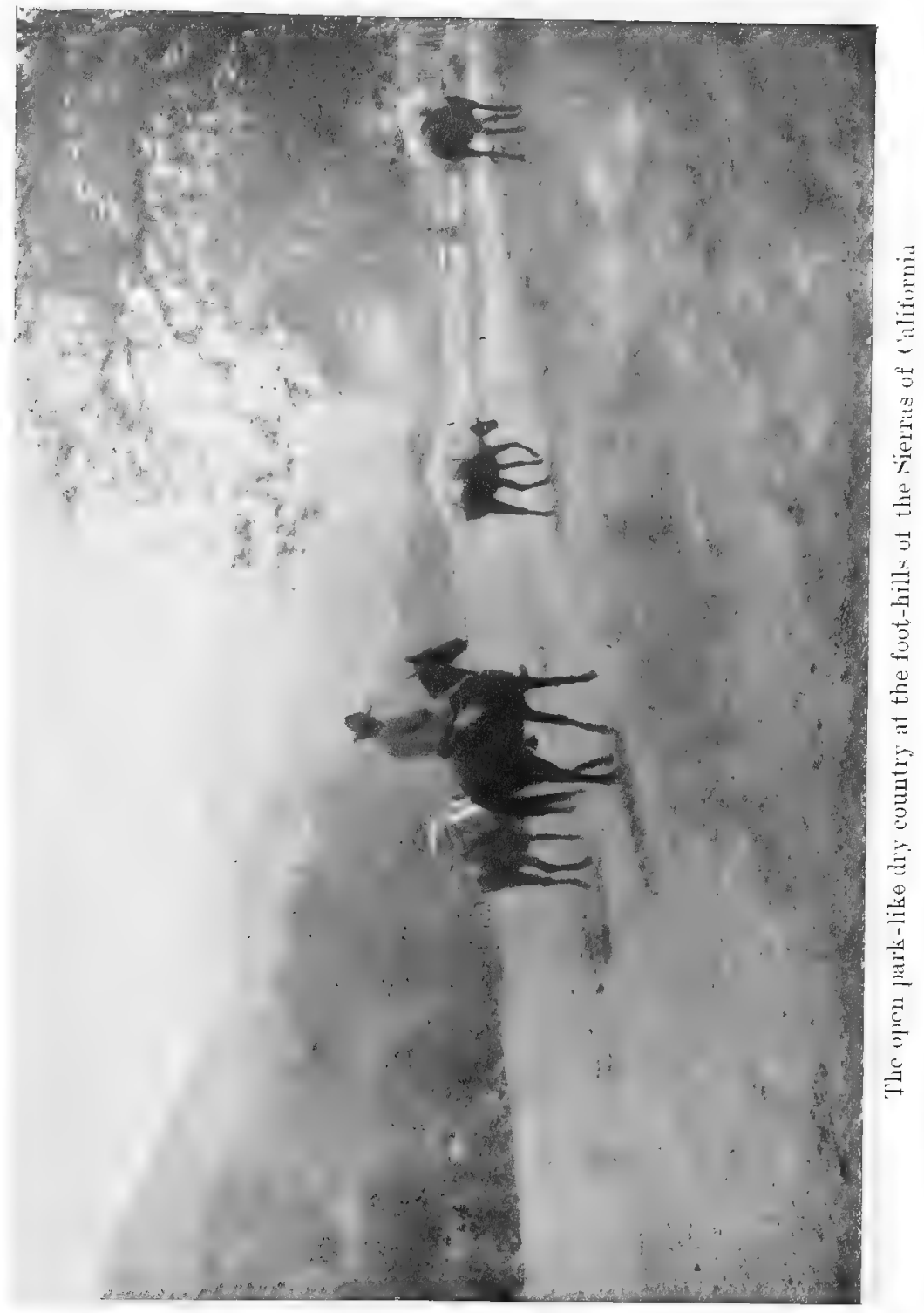




$$
\text { . }
$$




\section{GILBER'T AND GOLDEN TROU'T 181}

site is dependent entirely on the natural pastures which are widely scattered. We are nearly 8,000 feet above the burning hot valley of St. Joachim. As the sun leaves us we shiver with cold and look with commiseration towards that valley where people are seething in a temperature of 110 degrees or more. Camp is quickly made. The process is simplicity itself; horses and mules, unsaddled and hobbled, are turned out to feed on the succulent grass of a neighbouring wild meadow. A fire is built and a simple meal is cooked. We have no tent, for none is needed during this dry season; we are content to find a piece of smooth ground, roll ourselves in the warm blankets, and sleep till dawn. Fortunately, the blankets are heavy, for the night is bitterly cold, and as we rise we see the blue-white frost on the grass. Breakfast eaten, we go for the animals. We remarked that the tinkling of the mule bells no longer sounded, and we are told that it is quite customary for the animals, when their hunger is appeased, to go into the dry woods where it is warmer, so we commence a careful search for the missing creatures and finally discover them more than half a mile from the camp. After finding them, the cussedness of the mule, so world-famed, asserts itself, and notwithstanding all our efforts, over an hour passes before we finally have them in hand. The effect of the elevation is very noticeable, and any attempt at running results in the most distressing symptom of suffocation. Finally we are off again. The trail, scarcely visible, winds up and down steep gorgesin places so steep as to appear impossible for beast 


\section{WILD LIFE AND THE CAMERA}

or man-through dark forests of magnificent timber, along glades where the ground is a veritable carpet of many-coloured flowers. Flowers of all seasons, blooming together, make the most of the all too short summer; the earliest and the latest, utterly disregarding the season. Columbines, gentians, rich masses of scarlet painted-cup, are here, lupins in patches of purple, blue, and white, glorious yellow sunflowers, and many, many others, small and large, brilliant and delicate, whose names I do not know, but whose beauty make a picture delightful and wonderful beyond all power of description. No garden laid out with tenderest care and most consummate skill could compare with this garden of the Sierras, nestling in this valley, watered by melting snow, kissed into life by clear and unclouded sunlight, and guarded by the encircling mountains whose summits, rugged, bare and treeless, cut the deep blue sky with startling clearness.

All sense of distance is lost in such a climate. Huge snow-polished faces of solid rock hundreds, even thousands of feet in height, appeared mere boulders of insignificant size. On we go through all this dazzling beauty, making our way toward a pass 5,000 feet above the garden valley: it is ten miles away, yet it seems that we must reach it within a few minutes. Higher and higher we climb up the face of the mountain, zig-zagging along the perilously narrow trail which is scarcely visible in the coarse gravel. As we go, this loose gravel, started by the animals' feet, rattles down the steep slopes into the valley 1,000 feet or more 


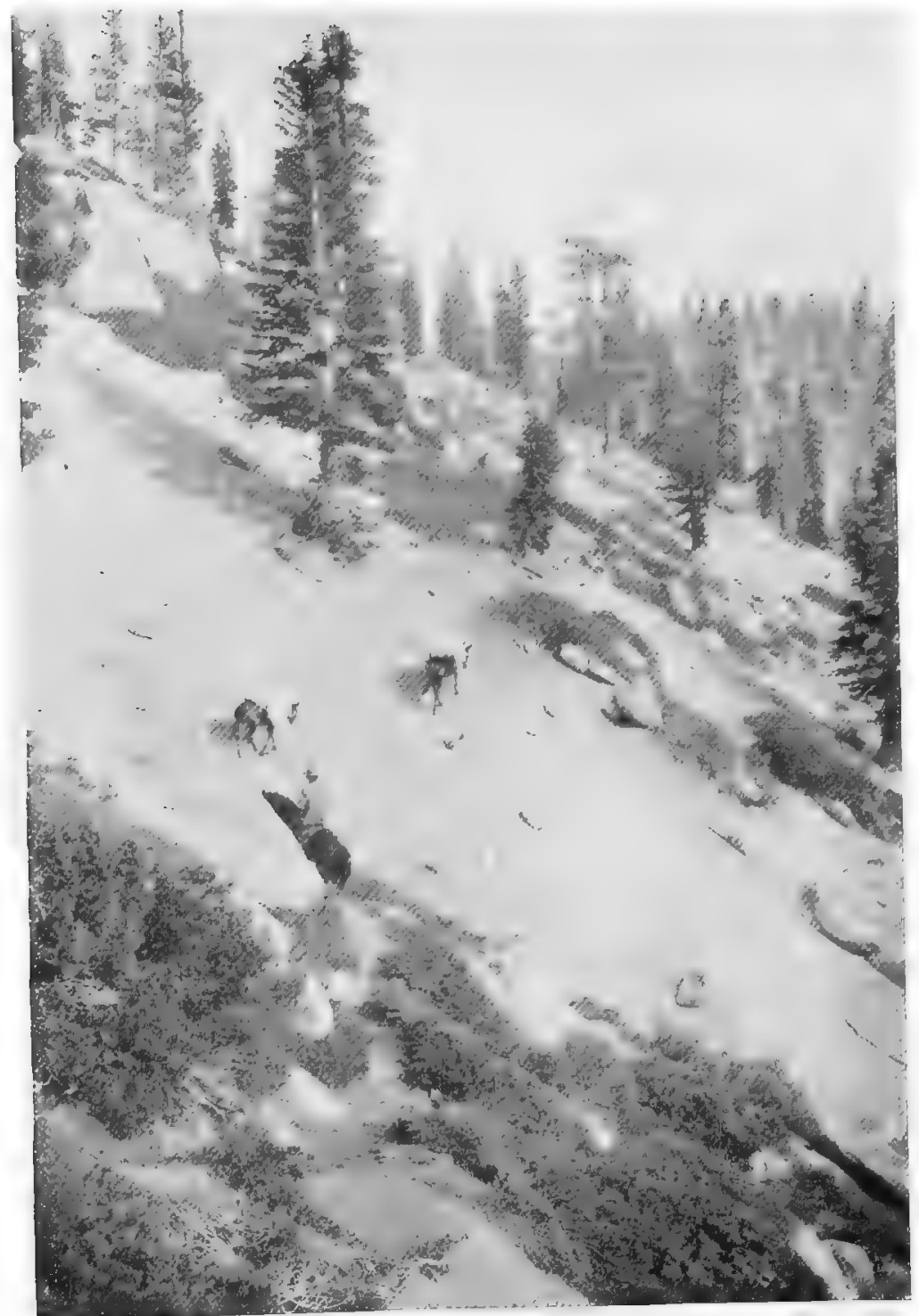

Risling alome the teep Sloges on the way to the Kern River. 


\section{GILBERT AND GOLDEN TROU'T 183}

directly below us. A mis-step, and we too should slide down, down to certain death among the faraway flowers; but the horses know well their work; sure-footed as goats they cling to every available irregularity; rising up the steep slides, they bound up a few steps at a time, then rest a moment to regain their wind. Wonderful little wiry animals are these mountain ponies. No horse reared in the plains could do such work; the stiff climbing, coupled with the high altitude, would soon kill them.

Long before we reach the pass 10,000 feet high, we notice a great change in the trees. The tall straight firs give way to shorter junipers whose gnarled branches bear silent testimony to the awful tempests which rage through the Sierras in winter time, snow-laden hurricanes which prune the weaklings, and often tear up huge trees whose roots have lost their hold. How wonderful a sight must these storms present if one could but witness them from a place of security; but these regions are locked securely by the key of winter against all intruders during nature's wildest revels. Why should trees select such sites, when every inch of growth is gained against such terrific odds? Why not choose the sheltered valleys where they could live and thrive in peace? Who shall say? This constant conflict between nature's different forces, this striving after that which is most difficult of attainment, seems to be one of the mysteries of life. It is apparently this struggle which makes life so well worth living, not for man alone, but for many of the so-called lower forms of creation. 

places that as we lean back the horses' heads are almost lost to view. It is slow work, and the sun sets while we are still two hours from the camping ground. A chilly, gruesome ride that last hour is now in the darkness of the forest. No trail could we see, and so on the judgment of the horses must we entirely depend, while we devote our attention to avoiding stray overhanging branches which frequently whip our faces smartly as we pass. Sore and tired after the long day's journey of nearly fifty miles, we reached the wild pasture near which was to be our camping ground. Scant time was spent in preparing a meal. Some cold water and dry food were good enough, after which we rolled ourselves in our blankets and, though the ground was hard, were soon sleeping peacefully, beneath the murmuring of the tall forest trees, dreaming of the sport which the morning promised.

If we accept the theory that the pleasure of fishing lies more in the surroundings than in the actual catching of the fish, then I would proclaim, without fear of contradiction, that no form of angling can compare with fishing for the rainbow trout of the roaring mountain streams of California and Oregon. In the wildest imaginings of the most fertile brain it would be impossible to make even a mental picture of the wonders of this western scenery; and surely no setting could be more inspiring to the lover of the gentle art of angling. Snow-born streamlets, trickling down from the lofty peaks, join one another as they work their way downwards. A dancing, merry gang they are, yet daring, too, for no obstacle may stay 


\section{WILD LIFE AND THE CAMERA}

their path ; like children they are, bubblingly lighthearted, but they grow old with bewildering rapidity, and in the dignified impetuosity of their maturity they become rivers, powerful enough to carve great paths through the rock-clad mountains, and through the deep cañons thus formed they march unceasingly toward the great Pacific Ocean. It is to these cañons, so deep that the sun can scarce find its way to the water, that he who would coax the rainbow trout from the dark green pools must betake himself. There, under the shading branch of the giant cedars and pines, a man may thank God that he is living and that fortune has brought him to this favoured spot. The fishing-well, after all, that is only an excuse for being there, a delightful excuse I thought on that memorable morning, when the dancing waters of the Kern River awakened me, and called out a bewitching invitation to come and try my luck with the fish. No second bid was necessary; the rod, slightly over five ounces in weight, was quickly assembled, and before the sun had bestowed his morning kiss on the river I cast my flies for the first time on a western mountain stream.

Many fascinating stories have been told me of the rainbow trout, and of the glorious country in which they live. The country was visible, and certainly the descriptions had done it but scant justice. Would the fishing prove equally satisfying?

Filled with delightful expectancy, I cast the flies on the ripples and pools, but for half an hour there 
was no response. Then like a flash the river was illuminated as suddenly as though an electric light had been turned on. The sun, rising in the clear blue sky, had gained the mountain top, then, as though pleased with the effort, the brilliant beam of light came with almost frantic speed down the steep slopes, over sombre forests and massive rocks, till it reached the river, where it lightened the deepest shadows, and transformed the gloomy waters into a mass of sparkling iridescent colours. It all happened so quickly that for the moment I was more interested in watching the kaleidoscopic transformation than in my fishing, and I carelessly allowed the flies to drift into the eddy behind a large boulder, where they sank several inches below the surface. A splash brought me to my fishing senses, and instinctively I raised the rod-too late, however, for I could not get in the slack before the fish had escaped. As quickly as possible another cast dropped the flies in the same place, and a big swirl showed that the fish was still eager. With my heart beating, as I trust it always will when I am casting for a fish that is in a rising mood, I once more dropped the flies above the stone and let them sink a little as they were carried into the eddying pool. A splash, a bending rod, a tightening line, and the reel sang merrily as the fish bolted for the shelter of a large overhanging rock. Cautiously I checked the outrunning line. The fish objected to this curbing and showed his resentment by leaping frantically from the water, filling the air with glistening drops and breaking the smooth surface of the deep green 



\section{GILBERT AND GOLDEN TROU'T 189}

The best time for this fishing seemed as a rule to be the morning, for an hour or so after the sun was on the water, then again later in the afternoon, when the smaller and middle-size fish would come to the open and rather shallow runs to feed. In the roughest waters the sport was always more exciting, of course, and many a hard tussle did I enjoy with large fish, when the water hurled past with a thundering roar which echoed back and forth among the rocks of the overhanging cañon. It is in such places that we realise and appreciate the difference between really wild fishing and the pale imitation which one finds in the near town club. As I said before, it is not only the fish but the conditions which make it so well worth while.

While camped on the Kern River we spent some time in search of the curious golden trout, one of the excuses which had brought us here. The very name of golden trout seems to possess some magic power, if one may judge from the number of people who have heard of it. Considering the fact that this fish is found in but one stream in the world, and that that stream is in the heart of the great Sierras of California, it is remarkable that it should be so well known even by name. Comparatively few persons have seen either the fish itself or pictures of it, though its beauty is so frequently mentioned; therefore it must be that the name has led to its becoming thus widely known. In point of beauty the golden trout should be given first place among the freshwater fish of North America, and this, compared with its extraordinary 


\section{WILD LIFE AND THE CAMERA}

history, and the grandeur of the country surrounding its mountain home, are excuses enough for any one who wishes an excuse for undertaking an interesting trip into these grand mountains of the far West. For those accustomed to camping in our Eastern States, the trip in itself through the Sierras, as we have already seen, is one great succession of surprises and delights, and the continuous clear weather of the summer months reduces camping to absolute simplicity.

Volcano Creek, the home of the golden trout, is one of the many streams that flow from Mount Whitney, the highest mountain in the United States. We followed the course of the Kern River along its gravelly stretches, where the water sparkled in the clear light, working our way around the rougher places where the river, turbulent and grand, fought its way among stubborn boulders, swung round the sharp bends, and through the deep, dark gorges, beautiful always, but particularly beautiful to the fisherman who, as though fascinated, would regard each likely place where he knew a fish must be hiding. In the near distance we hear a deafening roar, and soon we come upon the famous Volcano Creek dashing down the mountain side over the bed of lava and rock as though anxious to join the Kern River. With difficulty we climbed the face of the cliff, and then we found the creek in an entirely different mood. No longer boisterous and grand, but a small stream flowing peacefully through a meadow-like valley. The dense fringe of overhanging bushes made the prospect of casting by no means alluring; short 


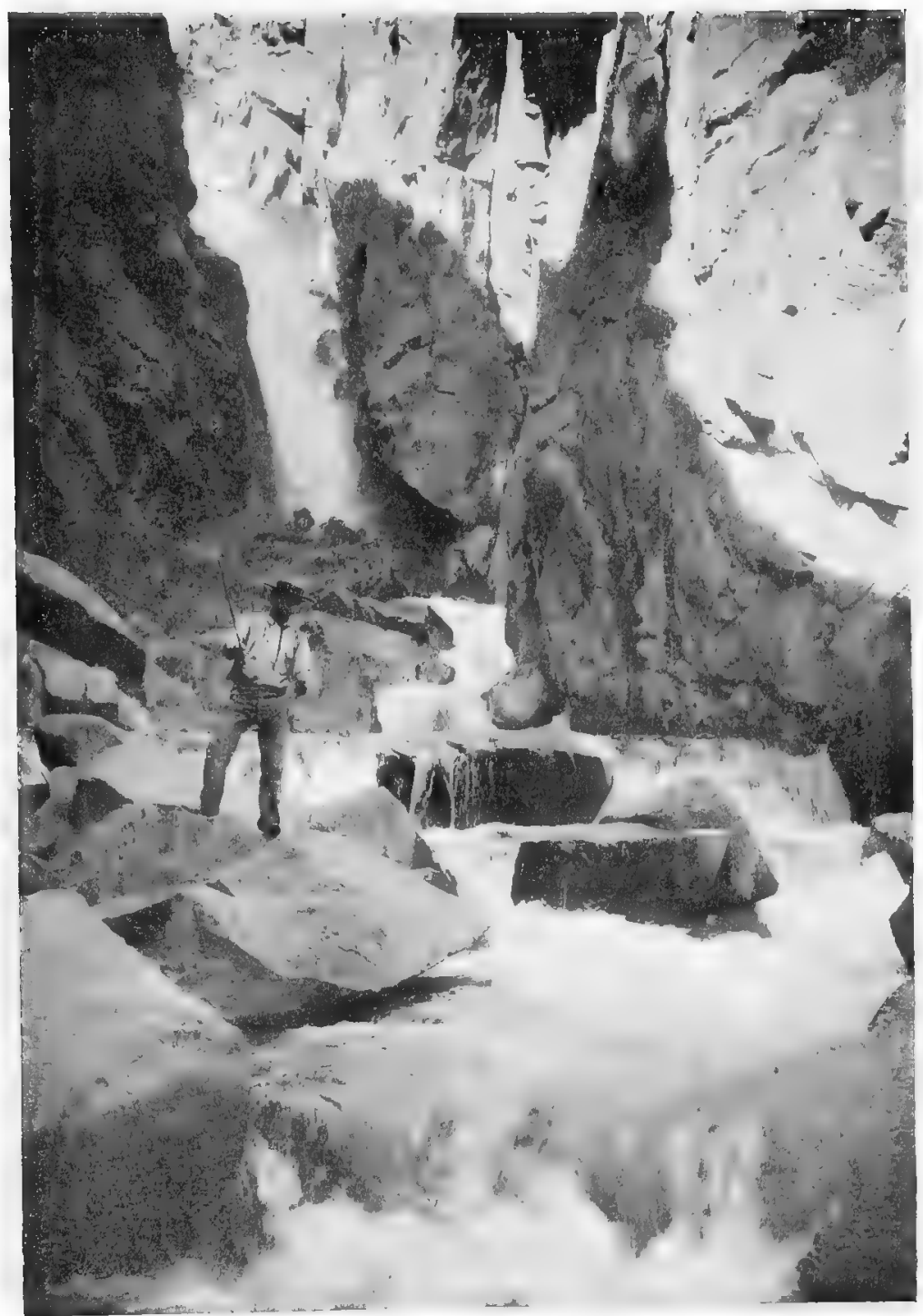

Fulcano C'reek. 



\section{GILBER'T AND GOLDEN TROUT 191}

casts were compulsory. Selecting a fairly promising part of the stream, I cast two No. 12 flies gently on the clear water. For some minutes there was no reply, then a sudden quick rise, a slight bending of the tip and the fish is hooked. The fight is short and fairly vigorous, and I land my first golden trout, well under a half-pound in weight, but beautiful beyond any freshwater fish I have ever seen, the most exquisite, dainty, and wonderfully coloured. Words will not describe it, for the colours of fish are nameless, and the iridescence changes each colour like the fire of the opal. This beautiful fish sparkles as though sheathed with tiny scales of the precious metal burnished to the highest degree of brilliancy. The under parts are of the deep orange hues of the mountain sunsets, while a faint, broad band of rose colour tinges the side from head to tail ; and as though to accentuate the brightness of the colours, a few velvety black spots are scattered above the median line. Perhaps it was well that so beautiful a creature should not rank high as a game fish. The flesh is delicious. But it is its beauty, coupled with the strangeness of its peculiar history of isolation and the grandeur of the scenery surrounding its mountain home, that gives it such a peculiar place in the list of anglers' trophies. Beyond that it has little merit, for though gamey for its size the fight lasts but a very short time, and in size it seldom goes over half a pound. Unfortunately immense numbers are killed annually by campers, frequently for no other purpose than to satisfy a disgusting desire for killing. An instance is on 


\section{WILD LIFE AND THE CAMERA}

record where a game warden found a heap of these tiny beauties on which was placed a card bearing the following: "We killed 1,000 of these fish in this place," and they were left to dry up, serving no purpose whatever. Strange it is that men can have so little sense of the eternal fitness of things. Why should such men take the trouble to camp when apparently nothing appeals to their sense of beauty or fair play, or I may add, of common sense?-for one would suppose that even they must realise that such slaughter means at last the destruction of the very objects which they declare give them sport. Perhaps they don't think. That at least is the most charitable view one can take.

Our stay in the Kern River valley was limited by the amount of food we had brought. Only too short a time did it last, and long before 1 had had enough of the fine fishing and delightful scenery we were compelled to start homeward. Wishing to see as much of the country as possible I chose to return by another trail, which led us eventually through the famous forest of giant redwoods, where the trees are large beyond all understanding, so large that carriages can drive through the divided bases of the still standing trees. The crownless tops detract somewhat from the actual beauty of these ancients of the forest, but in their grandeur and majesty they stand alone among all the trees of the world. Their destruction for commercial purposes would have been a national, or I should say a world-wide calamity, and we should be grateful to those who, like 


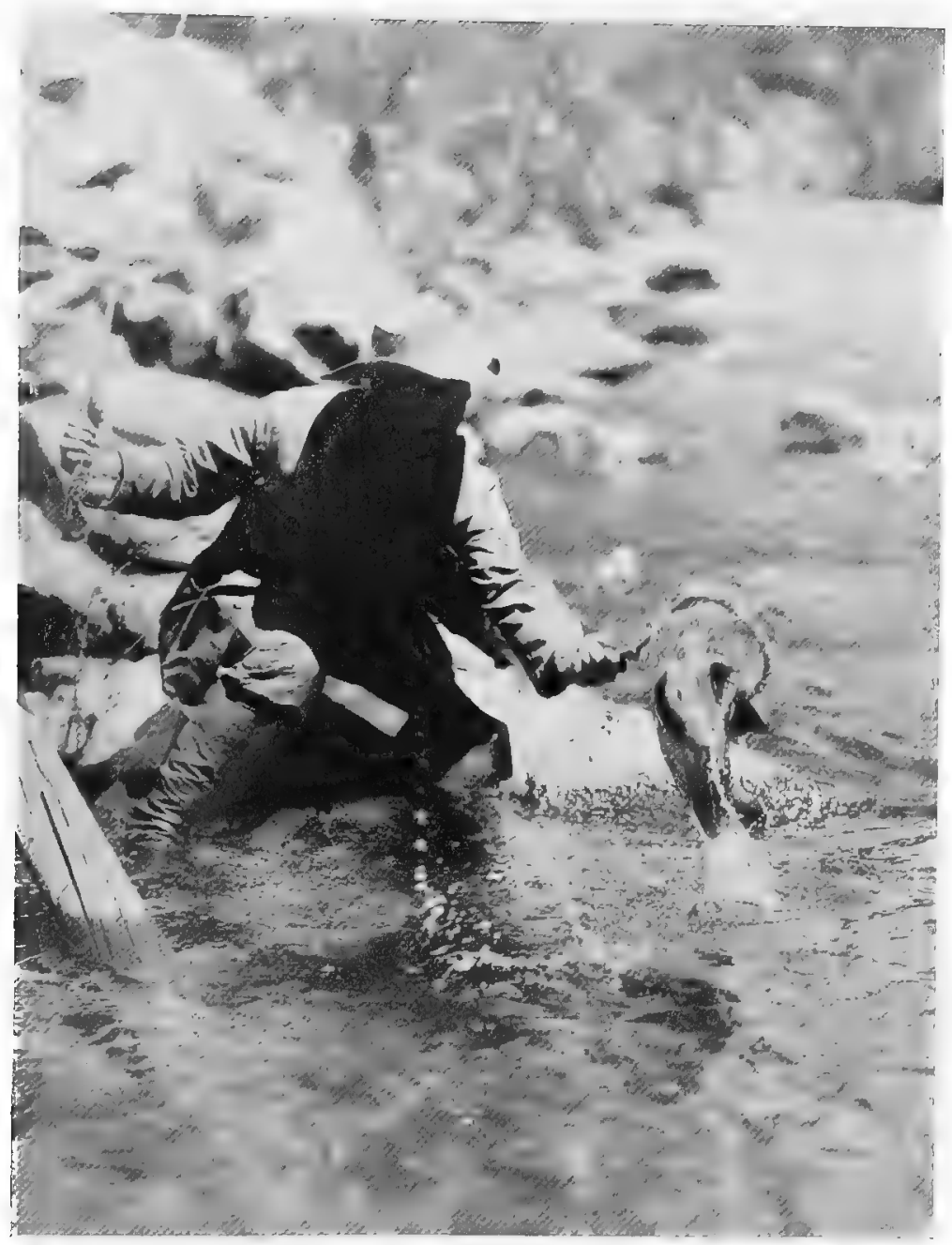

Isanding a large Gilbert Tront in the Kern River (talifornia). 


\section{GILBERT AND GOLDEN TROUT 193}

Theodore Roosevelt, were instrumental in saving these living relics of the past for generations of mankind yet to come.

In writing of the rainbow trout it may be advisable to go cautiously, for the ground is dangerous with an uncertainty, due to the many and confusing varieties of the species, as well as to the conditions under which they are found. In the strictly technical sense, the typical rainbow trout, Salmo iridens, is a distinct species which is found only in the small brooks of the coast ranges in California, from the Klamath River to the San Louis Bay in San Diego County. Throughout much of the rest of the western country many of the various species of trout are close relations of the true rainbow. In fact, many of them show differences so slight that they puzzle the experts, with the result that a wonderful state of confusion exists. Even the icthyologists are undecided about several of the rainbow trout and question whether the differences in coloration, habits, etc., are due solely to the geographical conditions, or whether they constitute separate species. As the points of variation merge one into the other, it seems impossible to give very definite descriptions of these fish. Indeed, so greatly are they affected by natural conditions that different parts of a river will produce fish which show distinction of colour, size and habits; and two streams scarcely more than a few hundred yards apart will each have what is apparently an entirely distinct species of rainbow trout.

The gameness of the rainbows shows as much variation as do their colour and markings. In some

W.L.C. 


\section{WILD LIFE AND THE CAMERA}

places they are decidedly sluggish; in others they fight well, but do not break water, while in many rivers they behave almost like the Atlantic salmon in their method of fighting when hooked, leaping frantically from the water half a dozen times or more in the endeavour to free themselves. On an average, however, they seem to be rather less gamey than the Fastern brook trout. Notwithstanding this slight disadvantage, it is more than probable that the time will soon come when the rainbow, together with the European brown trout, will take the place of the much-prized and too ardently sought after brook trout, as they are hardier and will more readily adapt themselves to the increasing warmth of the Eastern streams. This warmth is due to the ruthless cutting of timber, and the unfortunate necessity of clearing land, so that the streams are deprived of the muchneeded shade, consequently the water is warmed by the direct sunlight, and evaporation is so rapid that by the middle or end of summer there is a lack of water in streams which formerly contained plenty for the needs of the trout. The brook trout requires cold water, but the rainbow and European will thrive in water that reaches a temperature of eighty degrees. Colder water will, however, produce a more healthy and gamey fish.

Of the various forms of the rainbow trout, that found in the Kern River, California, and known as the Kern River or Gilbert trout ( $\boldsymbol{S}$. iridens gilberti), is perhaps the most gamey. It does not run as large as some of the other varieties, seldom in fact weighing over four or five pounds, 


\section{GILBERT AND GOLDEN 'TROU'T 195}

and never, so far as I can learn, more than eight pounds.

The Kern River is an ideal place for fishing, even though rather difficult of access. It rises in the high Sierras, and flows through the Kern River cañon. During the greater part of the year the water is extremely cold in the part inhabited by the trout, and only during July and August does it become at all warm. The river is very swift and has numerous deep, dark pools, to which the fish retire during the heat of the day. 'These conditions account for their extreme gameness, and make fishing in the stream a source of immeasurable delight to the angler. The superb scenery and the exquisite purity of the atmosphere add greatly to the pleasure of a fishing trip through this region.

The fishing season commences in June, as soon as the snow melts sufficiently to allow of travelling through the mountain passes, and continues as long as the weather permits. As a rule the trout rise readily to the fly, though like all meinbers of the finny tribe, they have their off days. These off days seem to depend, not so much on the weather, which during the summer varies little from day to day, as upon the hatching of certain larvæ. This theory is not believed by some people, but it seems more than probable to me. On a certain day, I, as well as others, who were fishing, found that scarcely a fish could be induced to rise, and the few that did were all small ones. In vain we tried different sizes and patterns of flies; grasshoppers were used, but without success. At last I took a very small bare hook and baited it with a clump of 


\section{WILD LIFE AND THE CAMERA}

the stick-like larvæ of the caddis fly, which were just about ready to hatch. This proved most alluring, and within an hour I had landed a number of trout, some of which were fine big fellows. Some days later I tried the same experiment with equal success when flies were disdained. I do not wish it to be understood that I regard this as a very sportsmanlike way of fishing, but as an experiment it was interesting.

For these Kern River or Gilbert trout, and others of the rainbow type, the most killing flies are usually the hackles, particularly the brown hackle with yellow body. The coachman, Montreal and grizzly king also prove good. The number eight hook seems about the best size; sometimes a larger one is better; while on one day I had no luck until I tried some on number sixteen hooks. These brought me no end of sport, and I landed some very fair-sized fish with them during the morning, while the men who were using larger flies had no luck.

There are no rules as to where the trout will most likely be found, but in general their habits are much like those of the Eastern brook trout. The smaller fish do not appear to be very shy, but if you would catch the large ones, your chances of success will be greatly increased if you keep out of sight as much as possible. This is especially true when fishing in the pools. In the fairly shallow rapids, where the trout go when feeding, they are not so easily frightened, though even then a long line will usually get more rises than a short one.

Different stretches of the Kern River seem to 


\section{GILBERT AND GOLDEN TROUT 197}

have a certain limit as to the size of the fish, and it will be noticed that only small ones are found towards the upper end, even where the river has deep pools and other conditions which are apparently suitable to the habits and needs of the larger fish. Usually large trout do not like either very cold water, or the somewhat sudden changes of temperature which take place towards the source of the river, where the water is very cold at night and in the early morning, but warms up after the sun strikes it. The largest fish are most often found in the quiet water, such as in places where the river broadens out, owing to some obstruction blocking its free passage, and forms small lakes. In order to fish these places successfully, it will be found necessary to construct a raft, unless you happen to have a small folding boat that can be carried on the mules, in which case bear in mind the fact that if anything can be broken, a mule will surely find a way to do it. So if you carry a canoe, pack it with the greatest care.

It may be well to remark that when fishing in California or Colorado, or in any climate where the air is extremely dry, and the sun very powerful, be sure to keep your traces (leaders) and fly snells thoroughly moist; otherwise you will require an inexhaustible supply of traces and patience, as the gut becomes so brittle that it breaks with little or no provocation, and consequently many fish will get away. The extreme dryness also plays havoc with rods, as it dries out the wood and renders it very brittle. The only remedy is to have wellmade rods, and keep them carefully varnished, 


\section{WILD LIFE AND THE CAMERA}

otherwise they will be sure to dry out, especially at the ferrules. When not in use the rods should never be left in the sun. Reels require more attention than in the East, both on account of the dust which finds its way into everything, and the heat which dries out the oil ; therefore clean and oil frequently.

In general, the tackle required for the rainbow trout and its allies is very similar to that used for the Eastern brook trout, though a slightly heavier rod may be preferred. A five and a half ounce rod should prove heavy enough for any one. The eight ounce rod recommended by a certain writer is out of all proportion to the size of the fish. Split bamboo of good quality is preferable to lancewood or greenheart, as it will not be so likely to dry out. But on no account use a cheap department store split bamboo, as it will not stand the climate. In any event do not fail to carry an extra rod or two in your outfit, and don't pack them all on the same mule, unless they are protected with more than ordinary care.

Without wishing to show any partiality, I would advise securing your outfit in the East, where the prices are lower and you know your dealer and maker of the rod. In the West, fly-fishing is of comparatively recent date, and has not yet reached the high degree of popularity and perfection that has been developed in the East. Hence the dealers are not so well stocked with rods, flies and other articles necessary to the angler.

Don't carry a small creel, as you should be prepared to carry fish that may be twenty or thirty 


\section{GILBER'I' AND GOLDEN 'TROU'T 199}

inches long, and few things are more delightfully aggravating than catching a fish too large for your basket.

Waders will not be needed in the dry regions, where the sun is so powerful that it burns the feet when rubber clad, and anyhow your clothes dry so rapidly that little discomfort is experienced after coming from the water. North of California waders may be found necessary, as the air is not so dry, the water is colder, and the weather not so persistently fine.

Besides the true rainbow and the Kern River trout, the other more or less distinct species embrace the following: the golden S. agua-bonita; the Nissuee, $\boldsymbol{S}$. iridens stoneii, the McCloud River, $S$. shasta, and the Western Oregon brook trout, S. masoni. All of the rainbow series are more or less profusely spotted with black, and have the broad, lateral band of purplish pink, from which they derive their name of rainbow. This band varies greatly with individuals; in some it is very conspicuous, while in others it is scarcely discernible.

The McCloud River species, which is the rainbow, most frequently used by fish culturists, is native to the waters of the Sierra Nevadas, from Mount Shasta southward, where in different streams it reaches a maximum weight of from three to eight pounds. It has been transplanted to many parts of the United States, and varies both in size and habits according to the existing conditions. In some of the very cold streams of Colorado it does not grow beyond half a pound, while in the warmer waters of the same State I am told that it may be 
found weighing as much as thirteen pounds. In Missouri it does not grow quite so large, while in the Au Sable River, Michigan, seven pounds is about its greatest weight. In the Eastern states it seldom grows so large.

In the "lower Columbia and coastwise streams of Oregon and Washington," the Western Oregon brook trout is found. It varies little from the typical rainbow, and never grows large enough to be a very important game fish, seldom exceeding a weight of one pound. 


\section{YELLOW TAIL FISHING OFF CATALINA ISLAND}





\section{CHAP'TER XIV}

YELLOW TAIL FISHING OFF CATALINA ISLAND

For those who enjoy a strenuous kind of fishing there is probably no place of easy access that will afford better opportunities than the vicinity of Catalina Island off the coast of California. There it is that the yellow tail stays during the greater part of the year and offers sport as abundant and as exciting as any man could wish. It is a sport that must appeal most strongly to those who, while enjoying the vigorous fight with the fish, do not appreciate bodily hardships and the consequent fatigue. Most of the fishing is done from an open boat or motor launch, for the day's use of which you pay about ten dollars with complete outfit. It is a dreamy, lazy form of enjoyment while waiting for the fish, followed by the keenest of excitement after the strike. Seated in a comfortable armchair facing the stern of the boat, with a rod on either side trailing some fifty yards or more of line, you travel slowly along, past rocky shores and islands of floating kelp, gently rolling over the long, undulating swell of the great Pacific. The soft air, the occasional low mist through which the powerful sun shines in iridescent splendour, the bright blue sky above and the exquisite ever-changing colour of the water, all combine to make this form of fishing a delight to the senses, and one is almost tempted to be satisfied 


\section{WILD LIFE AND 'IHE CAMERA}

with drifting along regardless of whether fish are caught or not. In this way it resembles fishing for brook trout, where the pleasure of wading through the rippling water beneath the arch of tender green leaves is perhaps the chief attraction of the sport. The catching of the fish is really only an incident, even though a much needed one. When after yellow tail your boatman takes you over the best fishing grounds, going at a rate of about three miles an hour. Outside of the chug-chug of the gasoline engine and the occasional screech of the gulls all is dreamily quiet, when suddenly, whirr! and you grab the rod as the line flies out from the large, strongly-built reel. At the same moment the boatinan stops the engine and the fun begins. You cannot stop the mad rush of the fish, especially if it is a big fellow; the best you can do is to press the leather firmly on the reel, and woe betide you if your thumb slips off and touches the line. Gradually the speed of the fish decreases, perhaps he starts towards you, and hastily you reel in the slack, taking care to release instantly in case he should start off again, and keepyour fingers clear of the handle if you value those same fingers. Should the fish burrow into the deep water, as they usually do, you will find ordinary reeling is out of the question, pumping is the only way to raise him, and that is done by quickly dropping the top of the rod and reeling in the few feet of slack almost simultaneously; then hold the reel firmly and slowly raise the top of the rod as high as you can and repeat the trick. In this way you gain about four or five feet each time and gradually the fish is brought near the 
surface. Look out then for frantic rushes which, though usually short, require careful handling if you would retain your connection with the fish. The yellow tail will not give up until he is absolutely done. Up to the very end he fights, and fights hard, keeping you busy for sometimes as much as half an hour or even longer, if it is a very large fish. It is hard to overestimate the beauty of these yellow tail as they plunge near the surface, displaying their wonderful iridescent colouring. Their sides literally gleam in the sunlight like polished brass as they dart back and forth. Then comes the acknowledgement of defeat. The fish turns belly up and the struggle ceases. If you wish to keep the fish the gaff is used. It is quick work, for the men are experts and death is practically instantaneous. If you have no use for it, the boatman simply leans over and gently releases the hook, and immediately the fish seems imbued with new life, and with a quick move of the tail vanishes with wonderful speed into the rich blue depths of its ocean home, and chug, chug, chug, the launch starts up and off again in search of more sport. It is not always that trolling answers in yellow tail fishing; why, no man can say, but the fact remains that sometimes you may troll all day long and never have a strike; then it is necessary either to cast or stillfish. Casting is splendid enough sport, but stillfishing in deep water is rather slow, drowsy work. One of the most interesting sights in connection with yellow tail fishing is to see the schools of fish feeding. The surface of the shimmering water will be oil-like one moment and the next will see a broken surface of 


\section{WILD LIFE AND THE CAMERA}

an acre or more in extent, the water churned up as though a volcano were in eruption beneath. Gulls, attracted by the turmoil and the chance of picking up scraps of small fish torn by the voracious yellow tail, arrive in numbers and add to the general confusion. Then suddenly it all ends, peace is restored, thousands of small fry have been devoured, and once more the limpid surface reflects the gorgeous blue of the sky. Near floating masses of kelp is usually a sure place for yellow tail fishing, but a great deal of sport is to be found in the bays quite close to the rocks. In fact some people prefer to fish directly from the shore, and when the water is fairly shallow this gives splendid sport, as then the fish is unable to ground and sulk.

The outfit necessary and advisable for yellow tail comprises a fairly stiff rod, not over eight feet long and weighing from 24 to 30 ounces (anything over 26 ounces is really only good for beginners); a good, stout and long line is necessary, about 300 feet of 15-strand cuttybunk is usually recommended; needless to say, a reliable reel is an important part of the outfit, for if the reel goes wrong it means loss of fish, line and all. The hook most highly recommended by $\mathbf{M r}$. Charles $\mathbf{P}$. Holder is the O'Shaughnessy attached to a stiff copper wire, which in turn is fastened by means of a swivel to the line. For bait sardine or herring are usually used, sometimes in connection with a large spoon. When stillfishing is resorted to it is often necessary to coax the fish and start them feeding by throwing in bait. Once they begin to eat, your fun begins, but there are times when apparently 
no power on earth will persuade them that food is necessary for their existence. The yellow tail of the Pacific are not the same as those found in the Florida waters. They are very much larger. Those caught on lines average over 20 pounds; they are seldom caught smaller than 10 pounds and usually run from that size up to about 30 or 35 pounds, though in exceptional instances they are very much larger. The season for fishing begins about the early part of April and lasts from then on until the end of December, and during this period there are few days, when the weather is fine, that a man cannot be sure of some good sport. 



\section{FISHING FOR SEA-TROUT IN NEW BRUNSWICK RIVERS}

W.L.C. 



\section{CHAP'TER XV}

FISHING FOR SEA-TROUT IN NEW BRUNSWICK RIVERS

For many weeks the fishing fever had been disturbing our minds and making our bodies restless. Ever since the first bluebird had come north and we had listened with delight to the ethereally delicate song, we had talked and thought and dreamed of fishing. (It was myself and wife that were planning this dissipation.) While we were debating the important question of where to go, a friend suggested "a perfectly splendid place" in New Brunswick, where trout of immense size and unquestioned gameness could be found in virgin pools of streams unknown to sportsmen. This certainly sounded alluring.

At last the day came and we started with glad hearts, for all seemed to be going well, notwithstanding certain small details which might have annoyed some people who were not suffering from a bad attack of fishing fever.

In due course we arrived at Fredericton, and the day following we headed north, going by very slow train to $\mathbf{C}$ - , on the banks of the $\mathbf{M}$ - River, arriving at midnight. Early next morning our guide came to the hotel and said that, though the season was a trifle early, he thought he could take us to where we should catch some good trout.

We took quite a fancy to this guide, who was a 


\section{WILD LIFE AND THE CAMERA}

true son of Ireland, good-tempered, and of wit full to overflowing; and, what was still more to the point, he knew a good deal about trout fishing. Very large flies, he declared, were necessary for the early fishing-No. 1 salmon, no less. I had with me a book of salmon flies, but having practically never used anything larger than No. 6 , I had very few of the large sizes and, frankly, I did not have much faith in them for trout. It had nearly always been my experience that small flies proved better than large ones. However, to avoid the possibility of having the guide blame our tackle if we failed to catch the fish, I searched the town and procured some very badly-faded silver doctors and Wilkinsons of the desired size. With our outfit in a light wagon and ourselves in a carriage we started on a twelve-mile drive to a river near which John, the guide, told us that his married daughter lived, and there we could put up for a couple of days while we tried the fishing.

We found everything thoroughly to our satisfaction-a nice clean house on a very tidy farm, and a promising river within a stone's throw. After a bite of lunch we assembled the rods and were poled up the river to a likely-looking pool, where we disembarked. Scarcely had I made half a dozen casts with the No. 1 Wilkinson, at the head of the pool, than a huge surge where the fly had just touched the water set my heart throbbing. Almost before I realised what had happened the line tightened with that magnetic thrill which makes the blood of a fisherman dance in his veins. There was scarcely need to strike, but I did so, and was 
rejoiced to find the hook had gone home. Just at first that fish played a gentle game, going slowly down stream to deep water, and I could not estimate his size; but suddenly he resented my restraining movements, and started to make things lively, first thrashing the water as he came to the surface, then making frantic runs here and there, trying all the while to get near a mass of drift brush which was caught against the bank at the farther side of the stream. Had he once attained his object it would have been good-bye to him, so I gave him the butt as firmly as possible, gradually steering the big fellow away from the danger, until I had him in clearer and quieter water. Every nerve in my body. was tense with excitement, and if that fish had escaped I believe I would have cried-or sworn-but we kept together, though between us there was sometimes seventy feet of line, taut as a fiddlestring, now quiet, now ripping through the water like a keen-edged knife. But the end was near. Slowly the big fish was coming. I had given him no rest and he was tired. Choosing a quiet piece of shallow water, I reeled him in toward the small landing net; but the net looked too small, and I feared it would not hold him. Very gradually I worked the big fellow toward it and at the critical moment scooped him up; but my surmise was correct-the net was too small, and the fish gave a mighty jump and cleared it, but fortunately the hook still held. To beach him was now the only way, and I backed up to the sandy bar and got my prize safely ashore. What a beauty he was-three pounds, five ounces-not 


\section{WILD LIFE AND THE CAMERA}

very large, it's true, but such a fighter; so silvery and so clean-cut; not two weeks from the ocean! Yes, he was a prize, and I could only regret that he had not fallen to my wife's rod (that sounds well !).

Now my wife had with her a creel, as she called it, and this creel was of the smallest size that is made-about nine inches long. It was a cause of much amusement to ourselves and to anyone who saw it; but the wife maintained that she had never caught, and never expected to catch, a trout long enough to bend in that creel. All the trout she raught had to be shaken backward and forward in order that head and tail might be said to touch both ends of the basket. In vain had I tried to persuade her not to bring such a ridiculously useless article with us, but being a woman-well, the basket came anyhow.

John declared it was just about big enough to carry a cast of flies, "if they weren't too large"; but still the wife insisted that she never expected to catch a trout that could not be put in that basket, and that, too, without its having to be bent. When John pointed to my fish and asked her whether that would go in her creel, she ventured to remind him that she had not caught it, and with that she began to whip the pool with a No. 1 silver doctor. In two or three minutes I heard a shriek of delight and saw her, with bowed rod, playing a fish, her first decent-sized trout (though she had at various times caught a large number of bass, one of which weighed ten pounds). Her excitement was delightful to watch, and the 


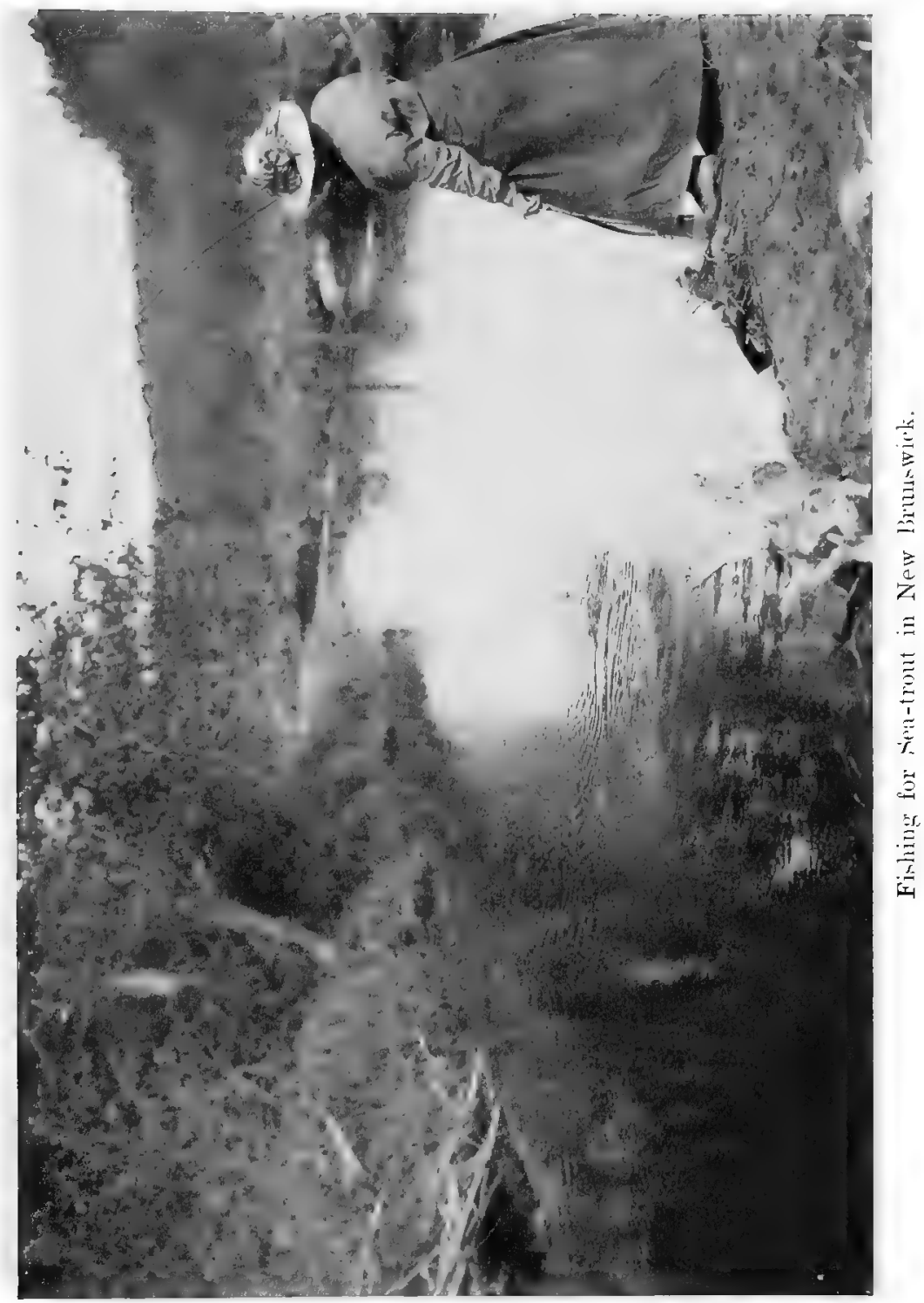



way in which she hurried that fish to the net was almost laughable. At last she had him, and he weighed a pound and three-quarters. But John never mentioned the tiny creel. He winked at me, and I guessed he was waiting for a larger fish. Pretty soon she got another one which, though a splendid fighter, was half a pound smaller than the first. With the exception of a few small fish we had no more luck that day, but we had thoroughly enjoyed ourselves, and the wife acknowledged that, after all, there were large trout in the world, though she had previously doubted it.

The river was an ideal one in most ways-fairly swift, clear, and icy cold, with deep pools here and there in which lay the big fish. On the second day of our stay here I had no luck at all, but the wife caught a fine three-pounder. Unfortunately I was not with her when she landed it, but there were great stories of her excitement. By bad luck she had left the tiny creel at the house.

On the third day we went down stream in the boat, fishing as we went along. We were going very slowly, the wife sitting in the bow casting carefully over every likely place. Suddenly there was a splendid rise at the fly; she struck too quickly, and missed. Almost instantly she had that fly back on the spot, but nothing came. Again and again the large fly was dropped on the quiet water behind a submerged stone, and with a disconsolate sigh she was just saying what a shame it was to have lost such a monster (all fish that rise to her fly and miss it are "monsters"), when there was a mighty splash and a beautiful fish leaped clear 


\section{WILD LIFE AND THE CAMERA}

out of the water as he seized the fly. A more perfect rise I have never seen. Away he went, down to the quicker water. Nothing could stop him at first, and the chances seemed entirely in his favour. Gradually the wife got control of the reel, and it was a caution the way in which she made that line come in. The rod bent till the tip touched the water, but nothing would do but that that fish must continue coming. Without realising how close the fish was, she reeled in past the nine-foot leader. At that moment she weakened, and the fish took advantage of the relaxing in the strain and dashed off. Down went the tip till the rod pointed straight at the fish ; the knot caught in the top ferrule, and the sudden jerk pulled out the tip and down the line it slid until it actually hit the fish. Things were certainly looking black.

"Look out! The big divil is eatin' the rod," called John, as the fish smashed the tip into tiny pieces; but the wife held on, and jumping out of the boat, soon had her three-pound fish safely beached. We laughed until there were tears in our eyes as we got out another tip, warning the wife not, on any account, to let the fish eat it.

"Now, let's put him in the creel," said John, with a twinkle in his blue eyes. "Please ma'am, an' here's the creel, will ye put him in, yersilf?" The comparative size of the tiny creel and the large trout was too much for John. "Let's cut off his head, ma'am, and put that in, for it's all it'll howld," and since that day the tiny creel has never been in evidence. During the afternoon we caught 
several fair-sized fishes, and all of them great fighters.

The following day we left the farm and drove to another and wilder river fourteen miles away. John had a boat on the $\mathbf{T}$ - - and in this we started down the river eight miles to his camp. Unfortunately the water was low; more and more thinly it spread over the widening, stony bed of the river ; finally it became apparent that the boat could only be taken down if empty, and so we walked to the camp.

It was a comfortable log cabin, beautifully situated, overlooking the river. Near it was a large and likely-looking pool, so we wasted no time before trying our luck. I lost two good fish and the wife took the greatest care in explaining how and why I had lost them. There were so many reasons for their having gotten off that $I$ was really surprised that they should have stayed on at all. To lose a fish of decent size is bad enough, but how it happened should never be told except by the unfortunate fellow who lost it.

However, I kept my temper (more or less), said nothing (or very little), and kept on casting and watching for retribution, which was thoroughly mean and cruel. It was not long in coming, and to my great delight I saw a nice fish take the fly that my wife so skilfully offered. Splash ! splash ! whirr! the running line made the reel shriek and the rod bent in a graceful bow. Only for an instant, and then it sprang back, the line hung limp-the tension was gone, and so was the fish. Had the wife been a man, we know exactly what 
she would have said, but the running water made so much noise that I could not hear her remarks. Then, smiling,--and that was contemptible-I asked her which of the many aforesaid reasons was the one which accounted for the loss of the immense (I put emphasis on that word) fish. Soon she had another and lost it, so we called quits and had a good laugh over our bad fishing. No luck fell to our lot that afternoon. We caught nothing heavier than three-quarters of a pound. Evidently very few large fish had come so far up the river. So we decided to work down stream until we should meet them.

John thought it would be wiser to use a large, flat-bottomed boat for the trip, as we could then fish from it with comfort, whereas the smaller one was so cranky that fishing from it, when loaded, would have been rather too exciting, and in places, even dangerous. The flat-bottom boat was evidently quite safe unless she took it into her head to sink, and from the way the water poured through the seams when we launched her, this was by no means a remote possibility. The next morning when we went to load her she was safely ensconced on the bottom. Fortunately the water was not very deep, and after some difficulty we got her afloat and loaded, but for the rest of the trip bailing was an important part of the day's programme. At nearly every pool on the way down we caught fish. Many of them were large ones, and gave us no end of fun, and as, unless they were injured, we always returned them to the stream, we felt there was no necessity for limiting our catch. 
In one of the pools a big chap rose several times to our flies without actually touching. "Now," said John, "this is the time to produce my big bird," and out of his pocket came an immense bass fly-the largest I have ever seen. It was put on the wife's leader and was sent whizzing through the air toward where the fish lay. With a mighty splash the fly struck the water. This was too much for any self-respecting trout. Up he came, and with a gulp took the offending disturber of his meditations. What a time he made of it! Up and down the pool; here, there, everywhere, and finally, just as it seemed about time to bring him to the net he got loose, and that was, of course, the last we saw of him. But it goes to show what I have always maintained - that occasionally a very large fly will excite or provoke a trout or salmon, and prove very effective when all else fails.

For several days we continued our way down the river, camping, usually, fairly early in the day. One afternoon, as we were about to pitch camp, the rain came down in torrents. Some women would have been discouraged at getting their hair out of curl, but the wife thought it great fun. Dressed in a waterproof, with the case of the waterproof for a hat (that's an idea worth remembering), she cooked us a delicious dinner.

I have been camping with people who, when it rained, regarded it as a personal insult for which one of the party (I was usually the one) was entirely to blame. "Why hadn't I told them it was like this, and of course they wouldn't have thought of coming." "How could anyone be 


\section{WILD LIFE AND THE CAMERA}

expected to sleep on wet boughs-in fact, how could the boughs be cut when they were wet, and even the ground was wet?" and so on; growl, growl, growl, simply because of some nice, refreshing rain. Why, I have had it refresh me for sixteen consecutive days, but growling did not do any good-in fact, so far as I know, growling has never yet stopped rain or any other trouble; rather the reverse, for it seems as though the growlers always have the most troubles.

Our last camp was at tide-water, some 16 miles from the actual mouth of the river. The tent overlooked a very large, deep pool, fully 200 yards long. On the opposite side a small sparkling brook added its share to the larger river. One day the fishing was not good in the big pool owing to the very high tide, so we amused ourselves along the bank of the smaller stream, and we made acquaintance- - a sort of bowing acquaintance-with a very clever and very aggravating trout. He lived in a small pool under an old, dead birch stump which bent over the water. I cast toward his home, thinking it a likely place, and it was, for instantly there was a splash and a glint of silver as the fish, which we subsequently named McGinty, came to the fly and missed it. Again I cast and saw him leave the shade of the big stump; but he changed his mind and returned. For some time I continued casting, without results, so I tried another fly and McGinty made a dart at it, but without success-at least, so far as I was concerned. After a while I actually hooked him, but only for an instant, and off he went. Then we 
gave him a rest, after which the wife tried him and had two fine rises and two equally fine misses.

So we left McGinty and went farther up the stream, getting some very good fishing, but nothing over one pound. On returning to McGinty's pool an hour or so later, we again tried to coax the wily fellow, but beyond coming out to take a look at our flies he would have nothing to do with us. Next day we tried him again, with just about the same luck; made him rise several times and hooked him once, but McGinty didn't like us well enough to desire a closer acquaintance, for, though we spent hours trying to lure him out of his hidmg place, we had to acknowledge ourselves beaten.

While fishing we saw several moose along the riverside, and one time got to within about twentyfive feet of a young bull, and watched him feeding for a long time. At night, as we lay on our bed of balsam boughs, we could hear the big creatures splashing through the water as they fed along the river's edge, eating the young maple leaves and other dainty tit-bits. It added greatly to our interest having these animals about us, but perhaps nothing gave us more pleasure than the rabbits, or varying hares, as they should be called. On one occasion we were camped on a grassy place where the ground was thickly studded with the fluffy, silky balls ot the seeding dandelion. Along came a rabbit, paying not the slightest attention to us as he daintily nipped off the dandelions, eating the stalks and discarding the seed head. Closer and closer he came until he was within two feet of me. Never have I seen anything more beautiful, and I could 


\section{WILD LIFE AND THE CAMERA}

not but regret that owing to the lack of light, for it was after sunset, it was not possible to secure a photograph of such an unusual sight. Another rabbit came into our camp, eating bunchberry leaves and hopping about in a most unconcerned way alongside of the fire and all about us, not even being frightened when I walked away to our tent for the camera; and, though the light was not very good, I got three fairly satisfactory pictures.

After all, the catching of fish is by no means the only pleasure one derives from a fishing trip. There are so many things of interest that one cannot see any but the most conspicuous, and the time goes so quickly that even these are not half seen or enjoyed. Most people altogether miss what is, perhaps, the greatest enchantment of the early summer woods-the half hour preceding the dawn of day, when the birds fill the air with their morning song.

Neither of us had ever seen the twelve or fifteen pounders that people tell of, and until we do we will come back and try again for the three or four pounders of the $\mathrm{T}$ - _ River, and perhaps we may, even yet, catch our elusive friend McGinty. 
MY FIRST SALMON : A FISHING TRIP TO NEWFOUNDLAND 



\section{CHAP'TER XVI}

\section{MY FIRST SALMION : A FISHING TRIP TO NEWFOUNDI,AND*}

IF the reader is no fisherman he had better turn the pages over until he find something more to his fancy, for my extravagant phrases-the result of fresh enthusiasm-will seem to him like the ravings of a madman. I am writing while my first salmon line is scarcely dry, and in spite of unfavourable conditions this taste of the sport has fairly whetted my appetite. A resolve, witnessed by the rushing river, has been registered by both myself and my companion to revisit the same dark pools next year. Never again, however, can we have the unforgetable experience of catching our first salmon. The thought of the very best day's shooting falls flat when compared with the memory of that moment of terrific excitement, when the line was tightened after a rise, and of the subsequent view of the great fish making its first leap from the water in its endeavour to break away from the silken cord which held it captive.

My friend and I had often heard of the wonders of Newfoundland as a fisherman's paradise, so we determined to take the trip. A guide was immediately engaged, also two packers, one of whom was to act as cook. Our outfit was bought and

* First published in Country Lifo in America.

W.L.C. 


\section{WILD LIFE AND THE CAMERA}

packed. In less than ten days from the time we had settled on the trip we started by train to North Sydney. From there, after a night's journey by boat to Port-aux-Basques, a few hours by train brought us to the place where the guide was to meet us. We found our men waiting for us. They quickly emptied our trunks, putting all our possessions into waterproof canvas bags, with which they loaded their dories, and we started, skirting the coast and reaching our destination-the mouth of the river-the following noon.

Our enthusiasm was somewhat damped by the accounts we received of the fishing. Owing to the protracted drought the rivers were unusually low, and the water absolutely clear. Consequently but few fish had gone up, and those that had were not in a mood for rising. There had been no large catches in any of the rivers, and very few big fish had been taken. Nor were there any indications of approaching rain.

For nearly a week we wasted our time, as I now think, about the mouth of the river, near which there were three fairly good pools. Everyone told us no fish were coming in, but from later observation I believe a few salmon entered the river every night. On account of the lateness of the season they did not loiter at the lower pools, but moved up stream as best they could to the upper pools. Most of the fish, however, were waiting in the salt water for the rise of the river, as was proved by the numbers that were caught in the nets which lined the coast near its mouth. These nets play havoc with the fishing, especially during 
the dry season, when the salmon remain for some time near the coast while waiting for high water. As a rule, little netting is done after July 1st, but this year when I left the island (July 15th) the nets were still doing their deadly work.

At the end of six days of industrious fishing, during which we got no rise nor saw any sign of salmon, we determined to move our camp further up stream to a point where we could fish ten pools within a distance of three or four miles.

Never shall I forget the first day we fished the upper waters. We had drawn lots for the pool, and my friend won. The day was bright though chilly, and for a wonder there were no flies; so sitting in comfort on a convenient boulder with camera ready, but with only faint hope in my heart, I watched my companion. For my object in coming was not only to fish but to secure photographs of the jumping salmon. Thus was my sport and interest doubled, so also I may add were my difficulties, for the successful photographing of the fish is by no means as easy as it sounds.

A silver doctor was the fly used, and carefully was it dropped near the edge of the ripples. The third cast rose a fish; imagine our excitement. And at the end of eight days we had found a pool that contained what we had travelled over a thousand miles to find. Acting according to instructions given to us by a master of the art, my friend let a few minutes lapse before casting againwhat long minutes those were! After that several casts were made, but without result, and we were both becoming frightened lest the fish was gone,

Q 2 


\section{WILD LIFE AND THE CAMERA}

when suddenly with a huge splash the fly was taken. Out ran the line with its musical whirr, a gleam of silver flashed in the sunlight as a grilse leaped from the water. Again and again it jumped and ran. For ten minutes it fought as no other fish ever fights; then it was brought to gaff. We felt no sense of disappointment at its size-only four and a half pounds-for it was a salmon, though a young one, but together we admired the brilliant silver colour of this fish-(after the salmon has been in the river for a week or two it loses the silver colours, grows almost golden, and then very dark brown)--as we shall probably never admire another.

The next pool, a small one, fell to me, and though I cast industriously for half an hour, I got no rise. In the next two pools we were equally unsuccessful. Then we reached one of the prettiest bits of water on the river-a round, dark pool, overshadowed by a huge rock. For the first ten minutes my friend cast in vain, then suddenly, without any warning, a fair-sized fish (to us it seemed enormous) leaped half its length from the water as it seized the fly. What happened after that I scarcely knew. There was a great amount of jumping, which I tried to photograph, a good deal of reel music, and then, after about twenty minutes, a cessation of hostilities, as the fish retired to the deep water and sulked. We were using light grilse rods, so the time required for landing our fish was somewhat drawn out, and with all the strain that could safely be applied, it required forty minutes to bring that salmon to gaft. It weighed just ten pounds-not a large fish, it's 
true, but still quite good enough for us, and I do not know who was the happier, I or my friend. He had secured his fish, and I had obtained some interesting photographs.

Later in the afternoon I got my first rise, and honestly speaking, I felt a good deal like the man who, the first time he went salmon fishing, had such a huge rise that he thanked his lucky stars the monster had missed, and immediately went home, for fear the next time the fish might be successful in taking the fly. My fish was not a monster, probably not more than fifteen pounds, but he took the fly on a very long cast, and as he made the first frantic jumps, the rushing water against the bellying line proved too much of a strain and the leader parted. Not more than five seconds of intense excitement had I experienced, but the thrill was beyond all things I have ever known, and the sense of loss when the strain so suddenly left the rod was awful. There is nothing more disheartening than the moment when the rod springs back straight, and you realise that you and your fish have parted for ever.

The following morning we arranged to move camp still further up stream so as to be near the best water. I decided I would try my luck in the pool directly in front of our camp before starting, and before breakfast (about five o'clock) I cast a Jock Scott on the running water at the head of the pool. No sooner had the fly sunk an inch or so than a fish rose rather lazily and without touching the fly. Instead of waiting I immediately cast over the same place, and got another unsuccessful rise. 


\section{WILD LIFE AND THE CAMERA}

My heart was throbbing vigorously as I cast again and again with no effect. I was just about to change the Jock Scott for a silver doctor, when the water broke about the fly, which was well below the surface. A glimpse of a dorsal fin, then I felt the line tighten, and instantly the reel began to hum as the fish ran down stream before making its first jump. The early morning sun, which had just touched the pool, was shining with wonderful brilliancy on the cliff of snow-white gypsum rock which formed the background to the scene, and the light, reflected from the water, gleamed on the silver scales of that fish as it flung itself in the air several times in quick succession. Over the pool we went, the fish tugging and jumping and in every way opposing my efforts to bring him to still water. There was no sulking; whenever not running, he jugged with such force that I doubted whether we could ever see each other at close quarters. But though a fierce fight, it was not a long one. The end came after not twenty minutes of the keenest excitement I have ever felt, and on landing the fish, which weighed but eight pounds, I must own to a sense of happiness that no other sporting experience has ever given me. Hitherto I had thought trout fishing about perfection, while my friend had always considered the catching of small-mouth bass as good enough for him, butwell, we don't talk about going trout or bass fishing next year. 'The Newfoundland salmon will suit us perfectly.

As a matter of education, the beginner who aspires to salmon fishing should, before buying his 
outfit, read some books on the subject, bearing in mind that the habits of fish vary greatly in different waters, so that the methods of fishing are, of course, also variable.

Patience is one of the main requisites for success. I used to have a theory that salmon and trout fishing were very much alike beyond the fact that one was on a larger scale than the other; but in reality they are very different. If there is a trout in a pool and he intends rising, he usually does so before many casts have been made. Not so with the salmon. One grilse of medium size required an hour of incessant casting over and about the place where I knew him to be before he would take the fly, though several times he acknowledged its presence by a gentle swirl. Such experiences are by no means rare.

Occasionally it is desirable to change the fly for one of a different size or pattern, but as a rule if a fish does not rise to a good standard fly, he will not be tempted by a change. There seems to be no possible way of proving whether fish are sensible to colours, or whether once they are in a rising mood they will not rise to anything moving that has more or less the shape of a fly. Trout may frequently be seen rising to pieces of leaves or flowers as they float down stream, while at other times flies of different kinds may struggle on the surface of the same water unnoticed. It is probable that the man who goes out with, we will say, three good flies, such as the silver doctor, the Jock Scott and dusty miller, will, in the long run, do just as well as the one who has his book filled with 


\section{WILD LIFE AND THE CAMERA}

innumerable varieties. Small flies are, according to some authorities, best for bright days, and large ones for dull days, and for early morning and late evening.

The season for salmon fishing in the rivers on the western side of Newfoundland is June, July, and August. The best known rivers, such as the Codroy, Robinson's, Grand and Harry's, are usually pretty well occupied (frequently there is a camp at nearly every pool), and it is well to find out definitely from the guide just how many pools will be at your disposal before selecting your river. There are, however, many rivers in Newfoundland as good or superior, but not as accessible from the line of railway. Among those I would recommend as good rivers are the Gander, Placentia, Salinonier, and many rivers along the various coast lines accessible by the steamboat service around Newfoundland. One good pool will often afford enough sport. Catching one fish does not seem to frighten the other occupants of a pool-several times we caught three or more fish from one pool in quick succession, but it is unpleasant to be so restricted, especially in a wild country where all fishing is free.

As a rule the salmon in the Newfoundland waters do not run very large. Anything over twenty-five pounds is very unusual, though some are taken which weigh even thirty or more. In different rivers the size of the fish varies greatly. Whether or not this is due to the amount of netting that is done on the coast, or to natural causes, is difficult to say. It is certain that the nets hold the larger fish, while the size of the mesh permits the escape 
of the small ones. Could netting be stopped, there is no possible doubt that the fishing would at once improve. In years gone by netting was allowed in the rivers themselves; and even to-day, though it is contrary to the game laws, and though efforts are made to patrol the accessible rivers, it is done to some slight extent, the railway section hands being probably the chief offenders. We, ourselves, found signs of nets near several pools.

But taking all the conditions into consideration, it is only fair to say that the rivers are very fairly well protected for the angler, and we should be thankful to the country which holds its waters in trust for all who care to avail themselves of the splendid fishing equally free to all-to the rich and to the poor. Would that other countries regarded their fishing rights in the same broad-minded way. 

SALMON FISHING IN NEWFOUNDLAND 



\section{CHAP'TER XVII}

\section{SALMON FISHTNG IN NEWHOUNDLAND *}

For nearly two weeks fishermen's luck-bad luck-had been ours. Clear days and cloudy, hot days and cold had proved equally ineffective in making the salmon rise to our flies. In vain had we used every pattern in the books and whipped the waters from the time when the sun struggled with the morning mists till the glories of the northern sunsets had been lost in the gathering darkness. Four or five fish only had we taken and those small ones, and we felt that the time to become discouraged was about due. Still, each day we started out with renewed hopes and confidence, for it is hard to thoroughly discourage the ardent angler, and so we changed flies and changed flies till our leaden hopes were nigh worn out. Had we not seen fish, perhaps all this perseverance would have died early, but the river was literally alive with fish of all size, from the sprightly grilse that leaped high in the air and scattered the glistening drops like rotary wheels to big heavy salmon that would come to the water's surface with the slow deliberation of miniature whales coming up to blow. As we stood in the pools they would play around us, even jumping over our lines, but take a fly, oh no! Once in a while, just by way of aggravation, they

* First published in Country Life in America. 


\section{8

would come up slowly and gently toward the fly. It was certainly enough to try the patience of a double-haloed saint. But luck, whether it be good or bad, always changes if only you wait long enough, and so one fine day the spell broke, for within five minutes after we started fishing, my companion became connected with a fourteenpounder which put up a good fight and came to the gaff after about fifteen minutes. For an hour or so nothing else happened, so we moved to another pool, and almost immediately I hooked and took a medium-sized fish. For several hours we worked hard trying various flies. Two had at last risen to a small and much-worn "yellow sally." On the second or third cast it was taken by a nineteenpound fish. It was quite evident that only by using the greatest care could it be landed, for, as I have said, the fly was badly worn and the snell (it was a trout fly), was in no condition to stand much strain. Those were ticklish moments. Each time the fish broke water we expected to see him get off, but good luck was with us this day, and just as the gaff struck home the snell broke. One more jump and surely we would never have seen that fish at close quarters. Needless to say my friend was in a most cheerful frame of mind, for, up to this, the largest salmon he had taken was thirteen pounds, so here he had broken his record twice within a few hours.

The rest of the day we devoted to the pool in which the first fish had been taken. It was a very large one and contained plenty of good fish. There was here one in particular that I had set my heart on catching. He was a large fish, and though he had 


\section{FISHING IN NEWFOUNDLAND}

risen at least once every day, he never touched the fly, but, as this was apparently our lucky day, it seemed only wise to devote my energies to his lordship, and so I cast over him all the afternoon, trying every fly I owned. Once he acknowledged the "yellow sally," but fortunately did not take it. I say fortunately, because shortly afterward a small fish took it and forgot to return it to me; evidently it had been worn out by its previous use on bass, of which it had landed over thirty. Supper-time came and, as soon as the inner man had been satisfied, I returned again to the object of my attentions. Once more I began with the orthodox flies, but without result. 'Then, in desperation, a very large bass fly was tried, and no sooner had it touched the water than my big friend made a frantic but unsuccessful rush for it. For an hour or more I tried the coaxing qualities of all sorts of bass flies, and at last picked out a large royal coachman which had been in my book for over four years and was pretty well dried out, and certainly in poor condition to withstand the strain of a large fish, but it was about the only fly that had not been used, so on it went. The sun had already set and the gorgeous crimson glow illuminated the trees. As the line touched the water it disturbed the placid surface of the big, dark and smooth running pool and the thin ripples looked like quivering threads of glistening gold. Slowly the royal coachman floated along, for it was still dry and its large white wings stood out in strong contrast to the darkening background, when, without the slightest warning, there was an upheaval in 


\section{WILD LIFE AND THE CAMERA}

the water, and the fly vanished; surely this could not be my big friend, he would never be so gentle, for the line was leading slowly toward where I stood, and I reeled in carefully, when, ye gods and little fishes, how suddenly the scene changed! The line fairly flew through the water. Check it! Why I had not the slightest power to do so, and in an instant, at the end of a hundred and fifty feet of line, out leaped my big friend and thud, how the water splashed when the big heavy body struck it as he fell full length. Would that fly hold? Had I line enough? Would the light greenheart grilserod that I was using stand the strain? Would the fish leave the pool and go down the falls? These and a hundred other questions raced through my mind as I played the fish. Sometimes for many minutes he would sulk at the bottom of the pool, and it seemed surely as though $\mathbf{I}$ was fast to a rock. Then again he would rush with frantic speed down toward the falls and I had, at all cost, to turn him by straining the rod to its limit. The twilight was rapidly giving way to the approaching night and the question of gaffing was becoming more and more difficult. Nine times I brought that fish close to the guide, but with the uncertain light he was unable to see well enough to use the gaff with accuracy; each time he moved the fish would start out with renewed vigour, and each time I thought he would surely get away, but still the hook held, and at last when I brought him close to the guide, I raised him slowly and steadily until the dorsal fin was visible, and instantly the gaff was struck and the guide, raising the big fish clear of 


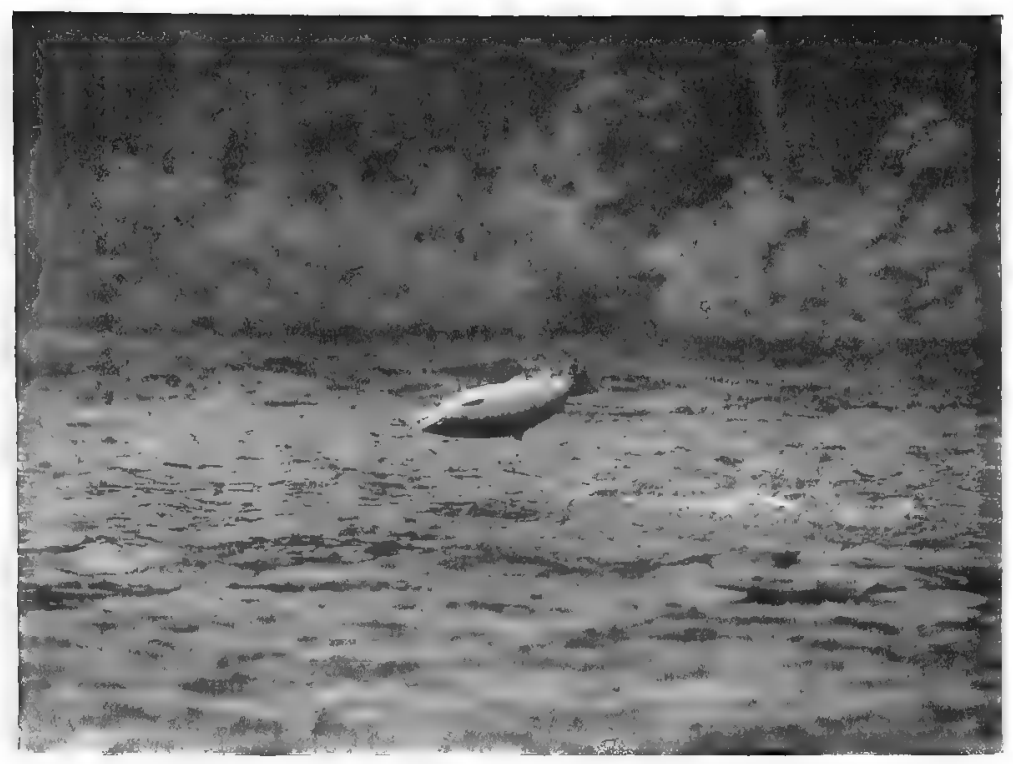

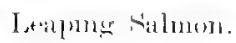

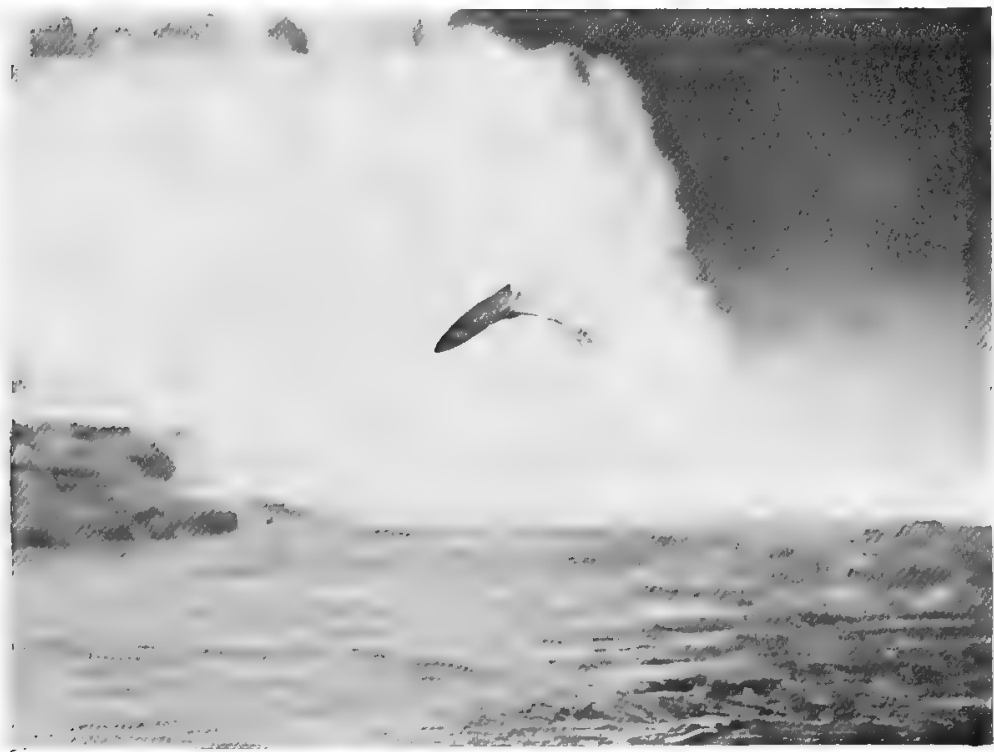

Iseapnug Salmon; the line in taintly visible. 
. 
the water, stumbled over on the slippery rocks and tugged the prize on to the grass; and I wiped five hundred mosquitoes from my neck, and let my heart resume its normal and proper position. By the light of a match we examined the fly. One of the two snells had parted and the other one was just about ready to go. It was a close shave. The scales ran up to $24 \frac{1}{2}$ pounds, and I feel now that a $24 \frac{1}{2}$-pound salmon with a light rod, a decrepit fly, and no daylight makes a combination calculated to give as much excitement as could be had with a forty-pounder under ordinary conditions and with a heavy two-handed rod, especially if it is your first large fish.

We remained on this river for nearly two weeks, when we decided to try our luck in one still further north. So, choosing a calm morning, we embarked in our dories and by night had reached the mouth of the river we sought. From all accounts the walking was so bad that to take up our outfit, photographic and other, to the head waters, where we hoped to find the fish, would be a task of very considerable difficulty. We concluded it would be better to put everything in the canoe and pull or pole the light craft up stream, provided there was sufficient water. So far no boat had ever been up to the falls, distant about twenty-five miles, for the water was very shallow in most parts, while in others the stretches of rough rocks and dangerous rapids might make the trip impossible. Of course it rained hard the morning we started. It nearly always does in Newfoundland I find. When one is used to such conditions it is quite astonishing W.L.C. 


\section{WILD LIFE AND THE CAMERA}

how little they interfere with one's happiness. We wereprepared for almost anything, so we did not care. The first part was fairly easy going; my companion and I walked along the bank, on the rocks or in the water according to the conditions, while the men pushed, pulled, poled and swore at the canoe; and so we proceeded, casting a fly occasionally on the likely-looking pools, but without results, except a few small trout, which no man likes when he is out for salmon. How strange it is that a man's attitude toward fish should change so completely under different conditions. Let him go out along his favourite stream near home and come back at the end of a very hard day's work with five or six trout, the largest perhaps not more than twelve or fourteen inches long, and he feels supremely happy; but let the same man, when fishing for salmon, hook a two or three pound trout, he indignantly flips it off in disgust. Yet what would he not give to catch such a fish in the home streams?

The severe rain made travelling rather hard, so camp was made early near a good-looking pool, from which we took a couple of small salmon just before dusk. Next morning while breakfast was cooking we got two more. The day was bright and clear, so that we thoroughly enjoyed working our way up stream. Toward noon we stopped at a small and not very interesting-looking, pool, and while the inevitable pot of tea was being boiled (that is the way they make it in the woods) my friend tried the pool. The result was a perfect surprise, for within two hours we caught fifteen 


\section{FISHING IN NEWFOUNDLAND 243}

fish, ranging from seven to eleven pounds, and all were extremely gamey. During the first part of those two hours I was kept busy with the camera, but all my plates were soon used. And I had made about eighteen exposures, many of which proved quite successful. It is scarcely necessary to say that of the fifteen fish only enough for our immediate needs were kept, the rest were released without being handled. Later in the afternoon the sky became clouded and the air sultry, an ideal day for mosquitoes and black flies. To say that they came out in thousands expresses it mildlythey were in millions. Never have I seen them so numerous. Before we could make camp it was necessary to build big smudges all around the proposed site. So great was the torture inflicted by these tiny pests that one of the guides, a man born and bred in the country, broke down completely and cried like a child. Next morning saw us nearing our goal, but the canoe had suffered badly. The paint was almost all scraped from the bottom, and in places the canvas was so severely worn that the wooden sheathing was plainly visible. Two or three miles over falls and shallows, and we entered the dead water, or lagoon, which was the main head of the river and into which fell one of the finest waterfalls I have ever seen. How high it was I would scarcely venture to say; it was, however, not alone the height, but the beauty of the surroundings which made such an impressive sight. Now the question was, would we find salmon in this quietwater or in the seething pool at the foot of the falls? 'Thousands of fish must have come up 


\section{WILD LIFE AND THE CAMERA}

the river during the past six or seven weeks of the run. Except in three or four of the pools below, there were none but the stragglers, and as they could not, of course, go up those perpendicular falls it was evident that they must be somewhere near by. Perhaps they were, but though we fished persistently for several days we only caught a couple of small ones, and saw or heard the jumps of half a dozen or so. Neither could we discover their whereabouts by paddling or drifting over the lagoon when the water was shallow enough to allow the bottom to be clearly seen. It is, of course, quite possible that the fish were in the very deep pools below the falls, waiting for conditions to be entirely satisfactory for spawning.

I was very anxious to see something of the caribou and their life during the summer; hitherto all my experience of them was confined to the autumn migration. Some days were therefore spent among the magnificent bills above where we had camped. 'This upper region reminded me very much of the English lake district, the marvellous lakes and streams, and the great rugged rockstrewn hills losing their summits in the shifting mists. The few caribou we saw proved to be very shy, and at no time was I able to approach them near enough for the limitations of the camera. Meat was needed as fish was so scarce, and also we wanted some material that would render the canoe watertight and strong enough to withstand the rough usage she was bound to sustain during the return trip. The conditions were daily getting worse; no rain having fallen for several days, the 


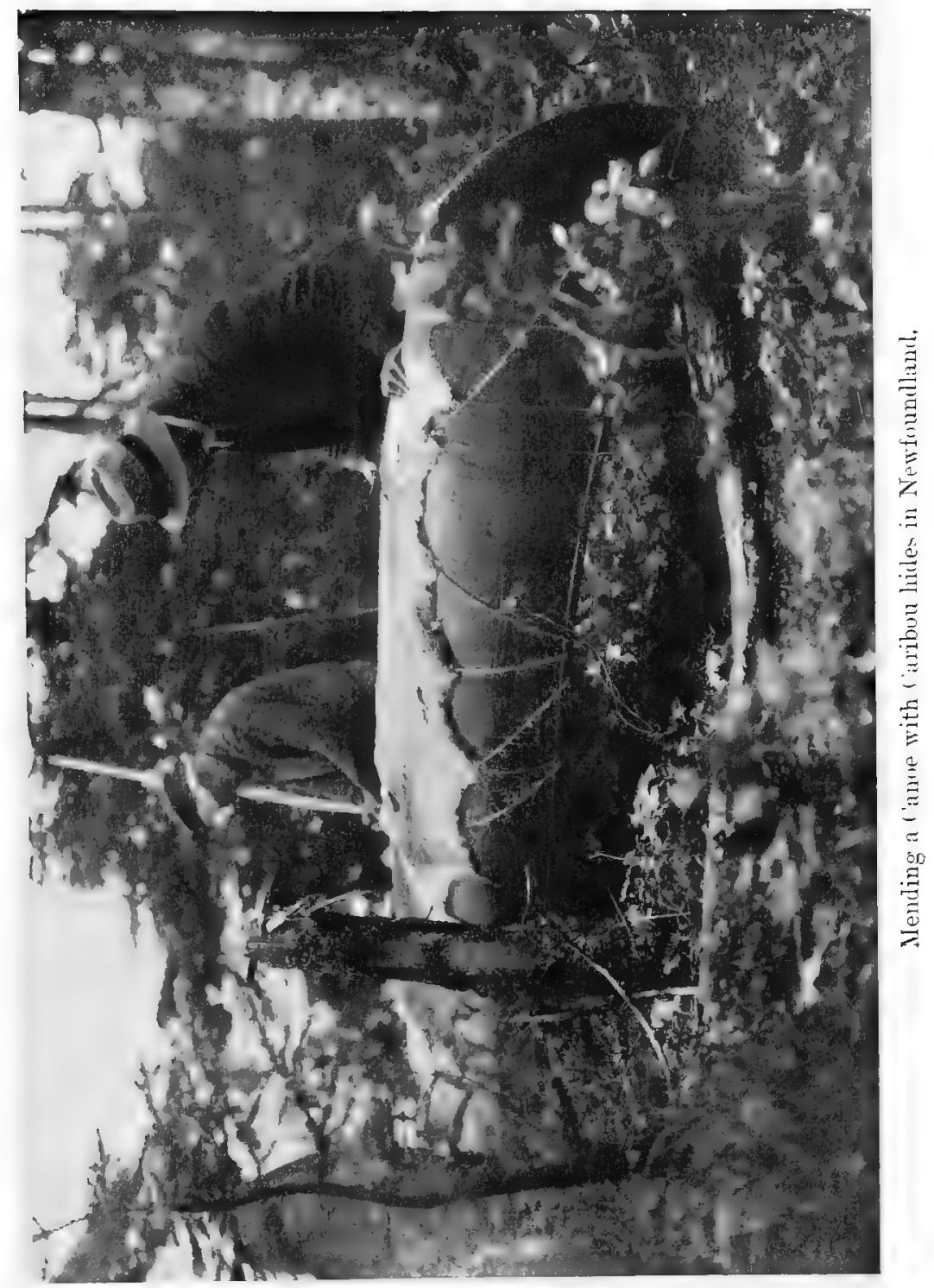



river would soon be too shallow to float the canoe, and she would have to be dragged over many miles of gravel and rock. To protect her we shot a couple of caribou and laced the hides tightly across the bottom of the canoe, thereby giving her a new lease of life. With this added weight it became necessary to reduce the load as much as possible, so each of us had to carry a pack and make our way as best we could back to the mouth of the river. It was a hard day's march across country, over soft spongy bogs where the wild geese greeted us with their musical honking, through beaver swamps where the tangled alders tripped us and the insect pests devoured us, through dense forests of diminutive firs and spruces, and so on down to the bay in which the river we had fished with such pleasure lost itself in the vastness of the sea.

No one who has once tasted of the joys of salmon fishing will question the statement that of all game fish the salmon easily takes first place. And yet, if the majority of enthusiastic fishermen were asked why they did not indulge in this thrilling sport, they would say that it is too expensive, or that open rivers are not to be found except, possibly, in regions too remote for their time and purse, and so, labouring under this delusion, they continue to anuse themselves with bass, muskalunge, and other interesting but nevertheless inferior forms of fishing. So far as salmon water in the eastern part of Canada is concerned, there is very little that has not been leased by clubs or by those fortunate individuals who have the means with 


\section{WILD LIFE AND THE CAMERA}

which they can gratify their desires. But for the man of moderate income, who counts on spending from thirty to sixty pounds (one hundred and fifty to perhaps three hundred dollars) for his well-earned vacation of two or three weeks, there is practically unlimited open salmon water in the island of Newfoundland. So far as I know, this is the only country in which laws absolutely prevent the leasing of rivers, either by individuals or clubs. The Government claims the rivers and a certain amount of the adjoining land which is open to any man who would fish. This policy, regarded even from a purely business point of view, has everything to recommend it. Every sportsman coming to the country leaves anywhere from seventy-five dollars to several hundred dollars, and the guides get pretty steady employment. When a club takes a river the fishing rights are restricted to a very few men, most of whom will seldom visit the club. And when an individual leases water he is usually very enthusiastic for the first season or so, then other places claim his attention and the river will be idle often for many years in succession, no man getting the benefit of it, either as guides or as fishermen.* It is true that the fish do not run so large as those found in the Restigouche or some of the other well-known rivers, but then we cannot all fish those rivers, and the fishing in Newfoundland is quite good enough to satisfy anyone not absolutely spoiled by unusually large fish. Under ordinary conditions a man should be able to

* Since this was written the game and fishing laws have becn somewhat changed, and now a rod licence is compulsory. 
average three or four fish each day. Slack days will come, of course, but they are usually offset by days of exceptionally good sport when one may, perhaps, land as many as twenty to one's own rod. 'The size of the fish is not by any means the only gauge of the sport, for the comparative weight of tackle and fish have to be taken into account. A large salmon on a heavy two-handed rod will not give as much sport as a much smaller fish on a light grilse rod. And then again there comes the question of the water : rough, rapid water increases the excitement enormously, while working from a canoe or boat on a large quiet pool greatly reduces the fun, in that it makes the landing of the fish a matter of far greater certainty. The whole sport consists in balancing the chances between fish and fisherman so that the element of uncertainty is developed as far as possible. Though the average salmon in Newfoundland waters will not run over ten or twelve pounds, there are plenty that will weigh over twenty, and there is always the chance of getting a thirty or thirty-five pounder. The different rivers seem each to have their own sized fish. One river will seldom or ever give anything over ten or twelve pounds, while another has a probable limit of fifteen, and so on, apparently without any particular reason. So also is it with the time when the best fishing may be had. One river isbest in June while another, but a few miles away, is not good until August. The man who wants three months or more of continued fishing can readily find it by following the run of fish as they come to the various rivers. If your time is limited and you 


\section{WILD LIFE AND THE CAMERA}

are restricted to a certain two or three weeks, don't plan to go to any one river until you have ascertained from reliable sources that that is the time when the fishing is good. Don't waste valuable time on a river waiting for the fish to come, but go where they are. If when you get there you find the pools full of fish that will not rise to the fly, do not be disappointed, for such experiences are by no means uncommon, and you will often strike an "off" day. No fish is more aggravatingly capricious than the salmon, both as to the time when it suits his lordship to rise and to the kind and size of fly he will deign to notice. Generally speaking, four or five of the standard flies will answer all purposes, especially if you have them in several sizes. Of these the Jock Scott, silver doctor, Durham ranger, fiery brown, and the fairy may be said to be the standard flies for Newfoundland. No. 8 is the size which will probably be found most useful. Nos. 4, 6, and $\mathbf{1 0}$ are also good at times, and occasionally a very large size will prove a fascinating lure. No rule can possibly be laid down, for rules as to flies for salmon fishing are like those of the English language "mostly composed of exceptions." One day you flatter yourself that you have at last found the combination, only to be sure the next day that you haven't. After keeping track of the number of rises we had to each pattern of fly last summer we were absolutely unable to say which was the best under any particular condition. In one river the famous Jock Scott seemed by far the best, in another it would be the silver doctor; while, perhaps, had we visited these same rivers a week or 
two earlier or later our experience would have been entirely different. On one river where we had most excellent sport the yellow sally was the fly, while the royal coachman (on No. 4 hook) came next. We had but three yellow sallies with us, and these were completely worn out by hard use. For late evening fishing, if all else fails, I would advise using a very large, light-coloured fly with a floating body. This will occasionally coax a large fish from his hidingplace when he would not notice a sunken fly, regardless of size. This advice, while not strictly orthodox, is nevertheless founded on actual experience.

When fish are rising well there is no need to worry much about the kind of fly to use, but there are times when, though they are jumping all around you, and even playing skipping-rope with your line, it requires something quite out of the ordinary to coax them. Then it is that the reserve list of out-of-the-way patterns comes in handy and perhaps saves the day for you. Some fishermen contend that it is useless to change the fly very frequently, nevertheless it will be very often observed that the first few casts with a newlychanged fly will rise a fish which has been entirely oblivious to the charms of the former fly. Each man has ideas on how fish can best be coaxed, and the delightful part of it is that each man knows he is right. One will say that when the fly is cast it should remain quietly on the water and be allowed to float quietly down stream, while another insists that the tip of the rod should be kept constantly moving, in order that the fly shall be given a lifelike action of swimming. Personally I do not 
think it makes very much difference, though I believe that when the fly is kept moving you are more apt to have the line under better control and with less of a belly to it. And after all that is one of the most important things to keep in mind; a slack line loses many fish, so do not cast a line that is longer than you can control. One fly only should be used, as there is danger, when you hook a fish, that the free fly may catch on a rock or snag. Whether to use the double or single hook fly is purely a matter of opinion. I have seen just as many fish lost with one as the other. On general principles, the single fly is the most sportsmanlike, but when very small flies are used it is quite pardonable to use the double hook, even though it is doubtful whether it is more effective. Good leaders are a very important part of the outfit, but the quality is scarcely more important than that they shall be thoroughly soaked before use. The heavier the leader the more necessary is it that it shall not be used dry. A heavy line is desirable, as it reduces the difficulty of casting, especially when there is a strong head wind. When there is danger of the salmon running down stream through rapid water, a very long line will be needed, not less than 100 yards. Under ordinary conditions 50 or 60 yards is long enough. It is not a bad plan, if you do wish to use a very large reel, to splice a length of 30 or 40 yards of fine linen line to the inner end; this will occupy very little space and be a good reserve. The reel or winch should be of the single-action pattern. 'The less complicated the better, but with adjustable 


\section{FISHING IN NEWFOUNDLAND 251}

tension to prevent over-running. Do not forget to keep it well oiled, or the bearings will soon wear out. For a gaff it is far better to use the plain tang hook, which is lashed to a suitable stick, than any of the screw-in kind, which are apt to turn at the critical moment. The automatic gaff is, like the automatic reel, undesirable.

In Newfoundland salmon fishing there is no best time of day. Almost any hour may be good; perhaps from 10 to 11 in the morning, and from 3 to 4 in the afternoon are, if anything, the best hours. The kind of day for the best fishing is another uncertainty. On one absolutely clear, quiet, hot day we got twelve fish from one pool in two hours (from 10 to 12 o'clock) with one rod. 'Then again we had good luck on dark, cold days, but as a rule you cannot count on much luck during rain. After all is said and done, the only absolutely sound advice that can safely be given to the salmon fisherman is: "To be on hand when the fish are rising, and give them the fly they want." How to do these two things no man can say with anything approaching exactness, and therein is one of the fascinations of the sport. If we could find a formula by which we knew we could catch a salmon, the whole pleasure would be lost, but, fortunately, no modern science seems to be able to fathom the ways of the game fish, and so we may continue in our uncertain way to catch fish if, when, and where we can.

Now the popular idea that Newfoundland is a very far distant and un-get-at-able place is much exaggerated. Let us first take it from the American 
end: One can leave Boston in the morning, and in fifty-two hours be actually fishing, that is, if one goes to the nearest and most convenient rivers. It might take from one to two or even three days longer if you would go to those that are more outof-the-way, where in most cases camping would, of course, be necessary. As a rule the accommodation to be found on the island is not suited to those of fastidious tastes. And though, of course, there are exceptions to this rule, it is, on the whole, far better to camp, for not only do you thus enjoy greater comfort, but you can pitch your tent alongside of the pool where you expect to fish, thereby saving what is frequently a long, tedious walk both before and after your day's fishing. If you can camp within a reasonable distance of a settlement, so much the better, for you can then procure fresh milk, butter, eggs and bread, all of which add materially to one's comfort. The comparative cost of the two methods is difficult to calculate. On the whole, camping is the cheaper, even counting the wear and tear of the outfit. From the point of view of the man in England, Newfoundland is neither so very far away nor so difficult to reach. The steamer will take you directly to St. John in a few days, and from St. John it is but a day to the salmon waters. But the question of camping versus staying in a house should be very carefully considered. The American, when he goes fishing, expects to camp. Not so with the Englishman. He camps when after big game but not when he fishes. To my mind the camping is in every way preferable. Not only is it healthier, but if you are fond of the open 
and not too much wedded to what you consider are your comforts (frequently purely imaginary) you will find that the camping adds immeasurably to the pleasures of fishing. Remember, however, that Newfoundland methods of camping are very primitive; carrying heavy outfits is not only undesirable but often impossible. So give up portable beds, tables, chairs, heavy kit-bags and similar impediments, and follow the custom of the country by going light, really light, weighing the ounces as well as the pounds. The outfit for Newfoundland is much the same as would be required for Maine, except that more blankets and heavier clothing are frequently necessary. Owing to the prevalence of rain and fog, everything should be carried in strong waterproof canvas bags, and it is well to be provided with a light canvas square, large enough to place over your dinner-table and protect you during meals. Eating in your sleeping tent is not altogether satisfactory unless perhaps your tent is of unusual and therefore inconvenient size. The open air dining-room is far more desirable. In some parts of the country tents are not altogether essential as there is plenty of bark with which a lean-to can be quickly made; it is safer, however, to have a tent. If you have long portages to make, then, and only then, is it advisable to trust altogether to the spruce or birch bark.

The question of waders is important. That is to say, if you use them they must be strong enough to stand the hardest possible wear. In some of the rivers the rocks are all placed on edge, and the stoutest hobnailed boots will last but a short time. 


\section{WILD LIFE AND THE CAMERA}

It is quite a question whether waders are worth all the bother they cause, for your feet get wet in any event, even though it is from the condensation caused by the warmth of the feet against the cold water. Many people prefer to use an ordinary heavy hobnail boot large enough to allow of several pairs of coarse, thick, warm stockings, these, with two or three pairs of woollen drawers make a very comfortable arrangement and are far less expensive than regular waders. I suggest several pairs of fairly thin drawers, as they are more readily dried than one very thick pair. 
ALONE UP MT. KATAHDIN 



\title{
CHAPTER XVIII
}

\author{
ALONE UP MT, KATAHDIN
}

A CLEAR frosty morning when all vegetation was covered with a silvery sparkling jacket. The chicadees hunted busily among the frosted leaves for their early breakfast, and the tapping of the woodpeckers sounded loudly in the bright crisp air; few other birds there were, and all nature seemed hushed. In the far distance Mt. Katahdin stood out sharp and well defined against the early morning sky, keeping her constant guard over the lower lands and the hills, so much smaller and less majestic than herself.

Morcross was astir betimes this Sunday morning, for a gang of lumbermen were about to leave by the little steamer, that would take them to the head of Lake Pummadumcook; thence they would start for their winter quarters in the more remote forests, there to continue tlie work of felling the majestic forest trees. The woodman's axe spares no timber that can be turned to money, and all trees that are of sufficient size must fall. Go where you will, the huge stumps, those silent monuments of man's devastating hand, stand up, decayed and fungus-covered, to show where once the tree had reared its head of murmuring pine needles or wind-blown leaves.

It was nearly six o'clock; the steamer, towing its W.L.C. 


\section{WILD LIFE AND THE CAMERA}

scows laden with winter provender, had left. I found a suitable canoe, in which I placed my belongings, and bidding a short farewell to trains and their like, I started off alone for my goalMt. Katahdin-translated from the Indian to mean the Highest Land.

No breath of wind stirred the surface of Lake Pummadumcook, and it was difficult to distinguish the reffections from the real objects. The shores are rocky and covered in most parts by fallen timber, whose bleached bones shine silvery white against the dark background of evergreens. How deathly quiet it was! Occasionally a loon would utter its piteous cry, but that only made the stillness the more intense, and the constant rhythmical dip of the paddle could scarce be heard as it sent the graceful canoe gliding over the polished surface of the water.

It was nearly eleven when, after some difficulty in finding the way, I reached Lake Ambajeejus, or, as it is also written, Ambejijis. From there Katahdin presented a magnificent picture. Its full height was seen to advantage as the low-lying foreground gave an uninterrupted view, which was reproduced in all its detail on the lake's surface. About a mile and a half of paddling brought me to Ambajeejus Falls, where there was a carry of nearly half a mile, as the water was very low. For a moderate sum, a guide, who keeps a horse for the purpose, hauled my things across the carry, and by little after noon I was on the dead waters of the west branch of the Penobscot river. Excepting at the falls it resembles a lake more than a river, and 
I believe it was formerly known as Passamagamet Lake.

'This lake is rather less than two miles in length and is studded with thickly-wooded islands. On one of these I landed, and, selecting a suitable place, decided to camp for the night. A crackling fire drove away to some extent the spirit of loneliness. But it was a great change from the surroundings of but twenty-four hours before-the Fall River steamer with its gorgeous display of electric lights, its music and its restless crowd. Here there was no noise save the gentle moaning of the pines and the distant murmuring of the rapids. Even to use an axe seemed an unnecessary act of violence, so the fire was fed with driftwood picked up along the shores.

As I lay on my bed of fir balsam and smoked my pipe after a hearty dinner, I almost wished that some companion were there to share the solitude. It was lonely, and before long I decided to seek my "pillow," though it was but seven o'clock. A night of refreshing sleep, sleep such as is known only to those who sleep in the open air, put me in a good state of mind and body, and after a dip in the cooling waters of the river and a good if not remarkably well cooked breakfast, I packed up and made another start. On my way up the river I noticed a likely-looking place for deer, and, realising that a nice fat yearling would give me a good supply of meat, I turned the canoe into a creek that wound its way through a large tract of meadow-like country. After walking a short distance through the grassy swamp I espied a deer 


\section{WILD LIFE AND THE CAMERA}

feeding, about two hundred yards away. The wind being in my favour, I stalked my game, and a shot from my Winchester gave me an ample supply of meat.

The weather by this time had grown threatening ; Katahdin was entirely hidden from view by the heavy rain-foreboding clouds, so I decided to camp and make ready for a wet night-one of the most unpleasant of things when one has but a small sleeping tent only three feet in height. No sooner had 1 landed my effects than the rain began. The tent was pitched, a bed of balsam hastily made, and by this time the rain was coming down in torrents. A fire had to be started, which under these conditions was not an easy task, but thanks to that ever useful article, birch bark, which burns readily, no matter how wet it may be, I was able to make a cheerful fire and cook some chops from that yearling deer.

The next few days were spent in exploring the surrounding country and in making photographs of the various kinds of woodland. One part struck me as being extremely fine and unusual. The ground was a mass of huge boulders piled up one against the other; these were entirely covered with a thick coating of moss, which in some places was rich green, and in others almost white, as though with age. Beneath this velvety carpet the water could be heard, many feet below the surface, seeking a path between the rocks. In one place I managed to obtain some to drink, but though icycold it was strongly impregnated with the taste of the cedar, and therefore not palatable. 'The cedars 


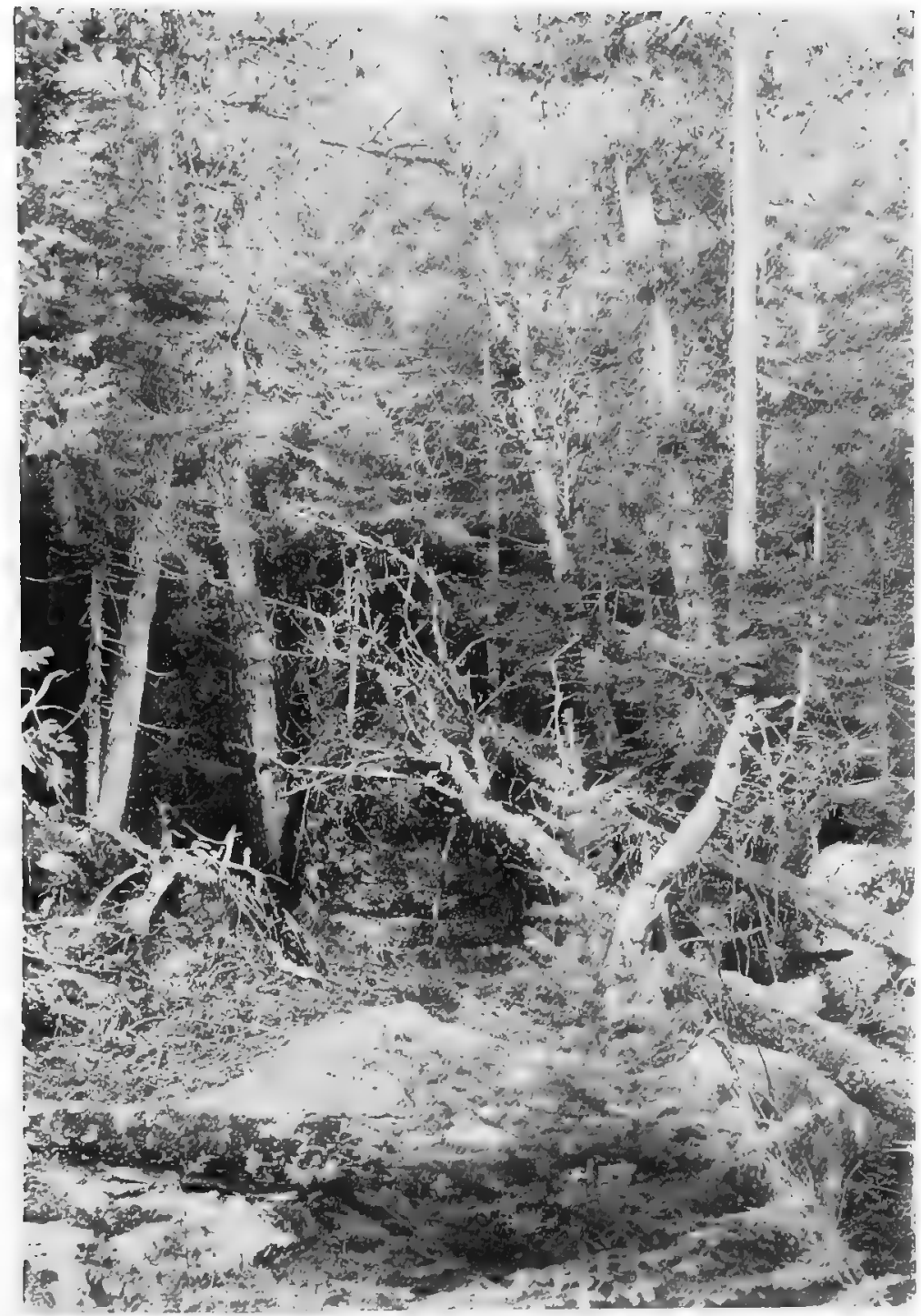

In the dense Womls below hatabdin. 
. 
and some other trees grow on these boulders, sending their roots among the moss, from which they probably draw the necessary nourishment. Here and there a tree falls and its roots strip the moss entirely from the rock, leaving the smooth granite bare and like a dazzling white jewel with its setting of rich dark green. The numerous tracks prove that this is a favourite resort for deer, but the difficulty of walking makes it anything but a desirable place for still-hunting.

Throughout this region ponds and small lakes may be found nestling snugly among the lowlying hills. These ponds are usually bordered by a strip of boggy moss, and here we find the pitcher plant, whose dark red vases hold their supply of water. What stories a fanciful child might weave of fairies drinking from these dainty vessels provided by nature! On the surface of the ponds lily-pads float idly, while the ducks dive and play among the long slimy stalks. Such a place affords the best shooting, both deer and moose frequenting the vicinity of ponds, especially those that contain pond lilies.

Throughout the woodland there is a perfect labyrinth of more or less defined logging roads; some of these lead to old deserted camps, others to the slides where the timber is launched, and many lead, apparently, nowhere but to some old decayed stump, the relic of a fine tree sacrificed to the cold steel of the woodman's axe. These roads, which are little more than rough timber-strewn paths, are most confusing, and where one tramps alone through the woods, the greatest care is necessary to observe 


\section{WILD LIFE AND THE CAMERA}

in what direction they lead. Along these paths, where the scarlet partridge berry adds its mite of brilliant colour to the rich though sombre shades of the forest growth, the snowbird hops along, uttering his tiny twit-twit, as he searches for food. They are the haunts, too, of the red squirrel-that ever busy, chattering, inquisitive little rascal who thinks the woods belong to him and him alone. He resents all intrusion and must needs examine carefully all intruders and loudly tell his neighbours just what he thinks of them. Here also may be found the ruffed grouse or patridge as he is named here, a tame bird which offers no sport, but is shot because in the way of food he is the greatest luxury supplied by the Maine woods.

On returning froin one of my photographing trips I had unfortunately left my camera in the canoe while I went to prepare some lunch; imagine my feelings, when, as I lay on the ground watching those impertinent thieves, the Canada jays-known here as moosebirds or whisky Jacks-stealing the scraps of meat from my deer, I was surprised by a strange visitor. She came crashing through the underbrush, halting only when she saw the column of pale blue smoke that rose from my fire. Her curiosity was aroused, and not seeing me, as I lay motionless, she came nearer, within thirty or forty feet. It was the first time I had ever been so close to a cow moose. What a size she looked as she stood there snorting and trying in vain, for there was no wind, to scent the arch enemy to her kind. After a few moments she trotted off down the bank and past my canoe and camera. I ran and, 
snatching the camera, tried to draw the dark slide from the plate-holder, but by that time my visitor had forded the narrow neck of water and disappeared among the trees on the opposite bank. My opportunity had vanished, and as I stood there I wondered why I had not taken the camera with me. It was the first time I had neglected to do so, and it was also the last, but no other moose ever visited my camp.

The next day I moved camp to Passamagamet carry, where I determined to learn the rudiments of poling a canoe through the rapids. I had been informed that there would be many rapids to pass before Katahdin brook could be reached, so landing all my effects, including my watch, and ballasting the canoe with stones, I started, after having carefully watched a guide who kindly gave me suggestions and went through a part of the rapids in order to show me how it was done.

Never shall I forget those first few moments of torture; the rocks loomed up larger and larger and ever increasing in numbers, while the water boiled and raced by as though eager to leave such unpleasant neighbours. "Gnashing rocks, with cruel foam upon their lips, sprang out of the obscure, eager to tear us. Great jaws of ugly blackness snapped about us as if we were introduced into a coterie of crocodiles," wrote Winthrop on his first experience of rapids. $\mathrm{He}$ was with guides, and I doubt not had he been alone his description might even have been stronger. As an eddying current caught the bow of the canoe, it would spin round, in danger of being dashed to pieces if the pole were not quickly dropped between 


\section{WILD LIFE AND THE CAMERA}

the frail craft and destruction. After many futile efforts the bow would be brought to point towards the turbulent channel, guarded on either side by monstrous stones, which, like watching devils, lay there ready to grind to atoms the boat that for an instant left the narrow path and came within their reach. A vigorous push, and the light craft shot over the racing waters, passed the rocks and for a moment wavered as though she would drop back again and face the stony demons; another push and we were out of reach of the eddy, and there was time to breathe and rest before attempting the next falls. These were passed after what seemed an interminable time, and then came the return. Running down stream requires almost more nerve, though less exertion, than going against the current. When fairly in the race you sweep past rocks at an awful speed. I had visions of an unwished-for bath and a canoe to be paid for, as the water carried me along utterly regardless of my feelings in the matter. A quick shove here and there against a passing stone would turn the canoe to where a suitable opening appeared. Occasionally we grazed a partly submerged rock whose paint-marked surface told of some canoe that had come in contact with it. Such beacons mark the channel through most of the rapids and shallow places. We were nearing the last falls, and I was "holding back" with all my strength when my pole caught between the rocks; my heart sank within me, as 1 realised that unless I recovered the pole I must inevitably be dashed to pieces; so, leaning over, even at the risk of upsetting the canoe, I jerked the pole 
frantically, and to my relief I felt it break loose from the stony clasp of the sunken rocks. I passed the falls without mishap, and gliding into the placid dead-waters of Passamagamet I rested from my labours, utterly exhausted by my first attempt at the rapids.

'The next day at 9 o'clock I left Passamagamet, carrying my canoe and things across the quartermile carry; the road was rough and rocky, and this, my first experience of canoe-carrying, strongly prejudiced me against such arduous labour. The wind was ahead, so that paddling to the next rapids, which bear the name of Katepskonegan (commonly pronounced Debsconeag), meaning in Indian language "carry place," was slow work, and it was afternoon when I commenced taking my load over the carry of about three-quarters of a mile. Another three miles by water and I reached the much dreaded Pockwockomus carry, which is a mile and a half long, and the roughest of rough roads, covered with rocks and fallen timber. My canoe, photographic material, tent, food, \&c., made three good loads of about ninety pounds each, so that this carry meant a nine-miles' walking. By the time I had made two trips I was so utterly exhausted that no power on earth could have made me carry that dreaded canoe. As it was growing late $\mathbf{I}$ concluded that I had better make ready my camp for the night.

When morning came my courage came with it, and I carried that canoe over that mile and a half. Again the wind was ahead, as also was the current, which ran swiftly. There were rapids to run and 


\section{WILD LIFE AND THE CAMERA}

another carry known as Abols-probably the short for Aboljacknagesic - and at last I found myself at the mouth of Katahdin brook, my point of departure for the great mountain that looked down frowning on me with its summit enveloped in clouds. I had reached the end of my river journey, and as it was but noon I decided to start that afternoon on my uphill march to the foot of the mountain. Leaving the canoe on the beach and placing most of my belongings inside the tent, I started off with a pack containing what things were necessary, such as food, sleeping bag, clothes and photographic outfit, perhaps sixty-five pounds in all.

The trail, which was newly blazed, showing that someone had recently been there, led for a time along Katahdin brook, then, branching off, it went up and down the thickly-wooded hills and swamps. In most parts the trail was quite distinct and therefore easy to follow, but the walking was difficult, and before the first two miles had been accomplished I discovered that my pack must be lightened if I wished to reach the end of my eight-mile walk that night; so, taking the heavy waterproof canvas cover from my sleeping bag, I put in it most of my ammunition and what clothes I could spare; these I cached beneath a large and prominent rock and recommenced my journey with the somewhat lightened pack. After walking another mile or so I came to an old, deserted lumber camp composed of four large log houses in various states of dilapidation. Two grouse were sunning themselves in the road, and a red squirrel sat on a tree-stump and harshly asked why I 
should come here, to this out-of-the-way place to disturb him as he was gathering material for his winter nest. After some difficulty I found the continuation of the blazed trail, which led through the leaf-strewn roads; on the way two deer, both does, bounded away and were soon lost to viewhow easily they make their way among the fallen timber, going so slowly, yet disappearing in an incredibly short time!

At four o'clock I crossed one of the beautiful mountain streams, and here my troubles began. Following, as before, the new blazings, which were few and far between, I had, without knowing it, left the Katahdin trail. It was getting dark, and I realised that I had lost my way; neither old nor new blazings could I find, and the woods were wet and spongy. Darkness had come upon me, and I must camp for the night. The prospect was not bright, and to make matters worse there was every indication of rain. Most of the wood was rotten and wet, so I had difficulty in making the fire, by whose light I built a rude shelter of birch bark, covering the soggy ground with the same material. While eating my supper a deer came walking quietly along, stopping for a moment when but a few feet from where I sat; its eyes shone like glowing coals, and as I moved forward to try and make out whether it was a buck or a doe, it got wind of me and scampercd off into the darkness.

The night was cold, and by ten o'clock I was awakened by the pattering of the rain on the birch bark. Drops of water soon found their way through the roughly-made roof, and morning found 


\section{WILD LIFE AND THE CAMERA}

me cold, wet, and thoroughly uncomfortable. After an hour's search I came across the blazings, and, following these for several miles, found they led to a new camp belonging to one Joe Francis, an Indian guide. There was no one there, and, seeing a slide on the face of the mountain, I thought it must be the one I was searching for, so I continued towards it though there was no trail. The woods were almost impassable, with fallen timber and a tangle of undergrowth, so, in despair, I turned back, determined to wait at the camp until someone returned. With difficulty I found the camp, and at three o'clock Joe Francis arrived with another guide who was carrying a load of moose meat. Joe informed me that I was about three miles out of the way, and that if 1 went due west I should find the object of my search. I followed his directions and arrived at the slide shortly before sunset, where I found a birch bark shack, of which I took possession. Leaving my things there, I went out to try to find some game, while there was yet daylight. Before walking more than a couple of hundred yards I got two grouse; these were quickly cooked, one for supper and the other for next day's lunch.

With a blazing, crackling fire in front of the shack to temper the cold, keen air, I went to sleep, happy in the thought that to-norrow would be fine, judging from the present indications, and I should climb the great pile of granite whose summit seemed to lose itself in the starry vault of the heavens.

The morning broke cold and clear, but the 


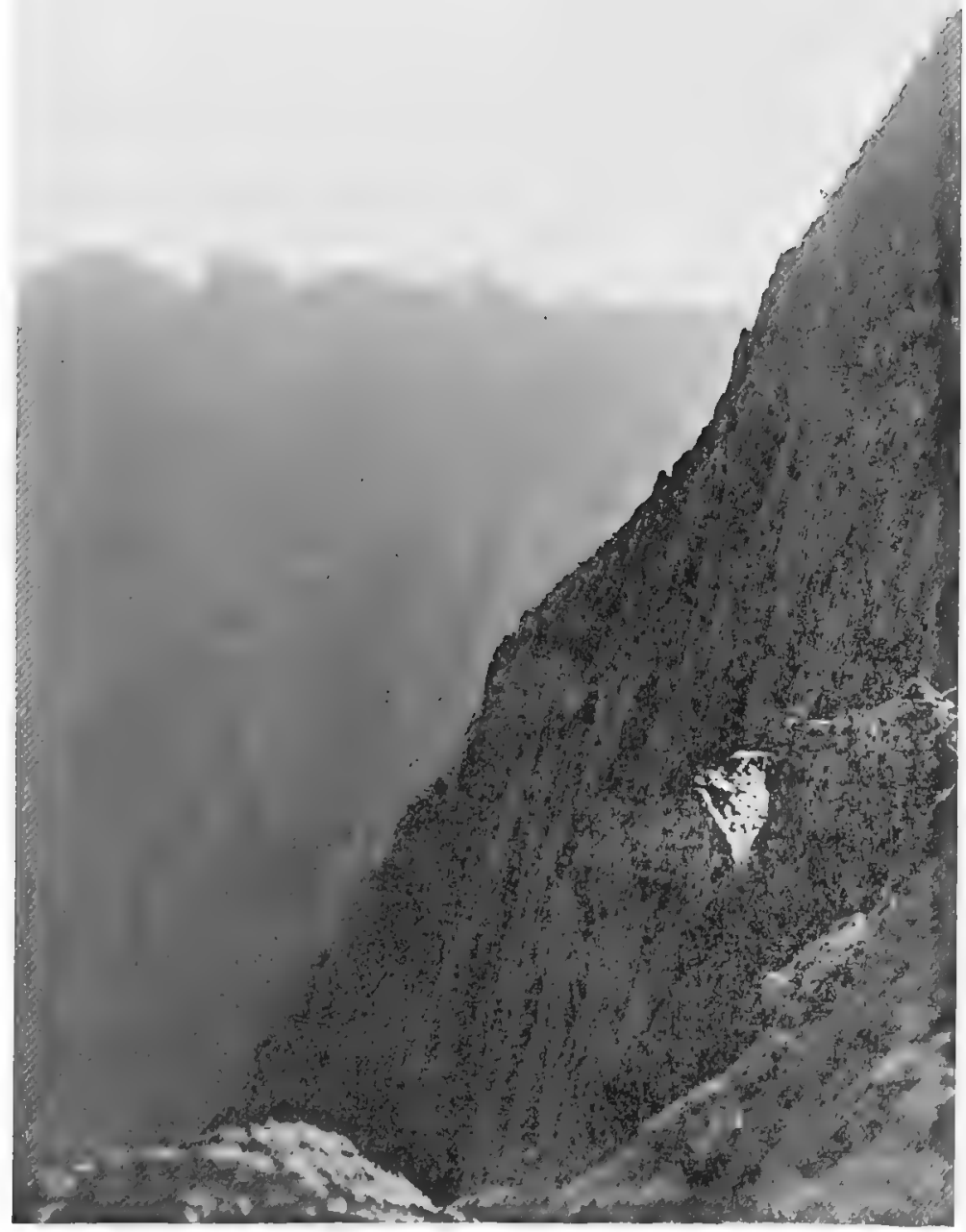

- The north-east side of the mountain is an abrupt precipice of solid rock about 4,000 feet high." 

wind was blowing half a gale from the north-west. The prospects were not hopeful for photography. At half-past six I started up what proved to be the most tiring climb I have ever experienced.

The slide, which is the best way up, on the south side of the mountain, is abroad strip of rocks and gravel. Most of the rocks are loosely piled up, with channels of gravel between, and here and there a scrubby bush, whose branches are extremely tough, strives for existence in such unpromising surroundings. The walking is most difficult, and it was only with the aid of a stout staff that $\mathbf{I}$ was able to force my way upwards. In parts the rocks were of great size, and the utmost care was necessary to avoid slipping between them. At a quarter past eight I crawled through an opening between two gigantic rocks and found myself on the table-land on the summit of Mt. Katahdin. This was not the highest point, that was about two miles further to the east. There it is 5,385 feet above sea level.

The wind was blowing with such force that I did not attempt to cross the narrow strip that leads to the highest peak, but contented myself with admiring the superb view. As far as the eye could reach there were rivers and lakes, large and small, shining like silver flakes through the thin purple mist; much to my disappointment the distance was entirely hidden from view, so that I was unable to get any photographs but those of the nearer objects. The north-east side of the mountain is an abrupt precipice of solid rock about 4,000 feet high. Over the lower lands the 


\section{WILD LIFE AND THE CAMERA}

clouds drifted lazily, for there it was evidently nearly calm. By the time I had taken a few photographs the clouds began to gather, hiding the topmost peak and warning me to make for the slide before that, too, was hidden; so, placing my camera into the pack basket, I made for the two stone columns or monuments that mark the top of the slide. The wind, which was increasing in force, was bitterly cold, and I was glad to reach the shelter of the rocks on the slide. Threequarters of an hour of jumping, slipping, tumbling and running brought me to the birch-bark shack, where I had left my things; these I soon packed up, and after a lunch of cold grouse, washed down with the most delicious ice-cold water from a mountain stream, I started back to the mouth of the Katahdin brook, well satisfied at having reached a goal so magnificent, one well worth all the labour it had cost.

As I entered the woods near the bottom of the slide, the squirrels and birds became more plentiful. I had noticed chicadees and robins not far below the timber line, and on the table-land there were two sparrows. They were, however, so wild that I was unable to get near enough to identify them. I could not help wondering why they should choose a spot so bleak and unprotected. Footsore and weary, I arrived at my camp on the river side by four o'clock. Looking back at the mountain on which I had stood but a few hours since, I saw that it was heavily draped with clouds, and I was glad that they had kept away while I was there.

The next day it was raining hard, so I rested 
and started off on my down-stream journey early the following morning, after taking a photograph of the mountain as it unveiled itself to greet the rising sun. The wind blew strongly in my favour, and in twenty-six hours I arrived at Morcross, the head of Pummadumcook Lake, and there bade farewell to the land of the balsam fir. 



\section{THE HEART OF WINTER}

W.I.C. 



\section{CHAP'TER XIX}

\section{THE HEART OF WINTER *}

The sky is darkening over while the morning is still young, no wind stirs the leafless twigs of the trees, an awful silence prevails, no break is there in the cloud which has completely overshadowed the sky. It is all a cold, dull, uniform grey. A few large fluff-like flakes of snow float dreamily downward and settle gently on the frozen earth, or catch on the bared branches. As silent members of the advance guard of winter they tell the world, in the language of signs, that Autumn has gone, and for three moons the land will be held in the cold grasp of snow and ice. Some say this is a period of death, but pardon them, for they do not know the winter moods. They think, because no flowers bloom and the birds are unusually silent, that there is no life. Why not say that the world of plant life is sleeping, wrapped in its spotless white sheet, sleeping and gathering renewed strength for the great battle of life that comes with the warmth of April sun? Away from the cities, where the snow is contaminated and disfigured by man's appliances, the winter has glories greater even than those of the summer, whether they are revealed in the blizzard which keeps men in their homes and spreads desolation among all that are not well

* First published in The Churchman. 


\section{WILD LIFE AND THE CAMERA}

housed, or in the quiet of the blue-skied day when the snow sparkles in the sunshine. The be auty is equally wonderful, and the extraordinary contrast forms perhaps its greatest fascination. To those who fear not the cold and the wind there is nothing more exhilarating than a walk through the woods and fields when the wind howls, and the snow travels with reckless speed, flying past trees and fences as though impelled with a mad desire to outdistance the pursuing gale. Snow imps dance a wild uncanny dance, hesitating a moment in some sheltered spot, then racing furiously across the open fields, whirling round and round in their wild endeavour to gather more snow. At each lull in the wind they lie down, invisible to the eye, leaving no track or trail, and we know not where they are until with the fresh blast of wind they rise up once more and continue their furious scamper. In the woods all seems dead; except in some sheltered nook no birds are seen. The grey squirrel has commenced his long winter sleep in the hollow of a tree. Chipmunks, too, are dead to the world in their underground homes, even the busy red squirrel has taken a day off and is snoozing comfortably in his nest. The wind whistles uneasily through the swaying branches, and the brown curled-up leaves of the oak rustle loudly. Now and then one of the leaves lets go its hold, and dances along on the smooth white ground with no companions but the wind and the falling snow. On such a day we see no tracks, for even did the wood folks move about, their tracks would be wiped out almost as soon as they were made. The 


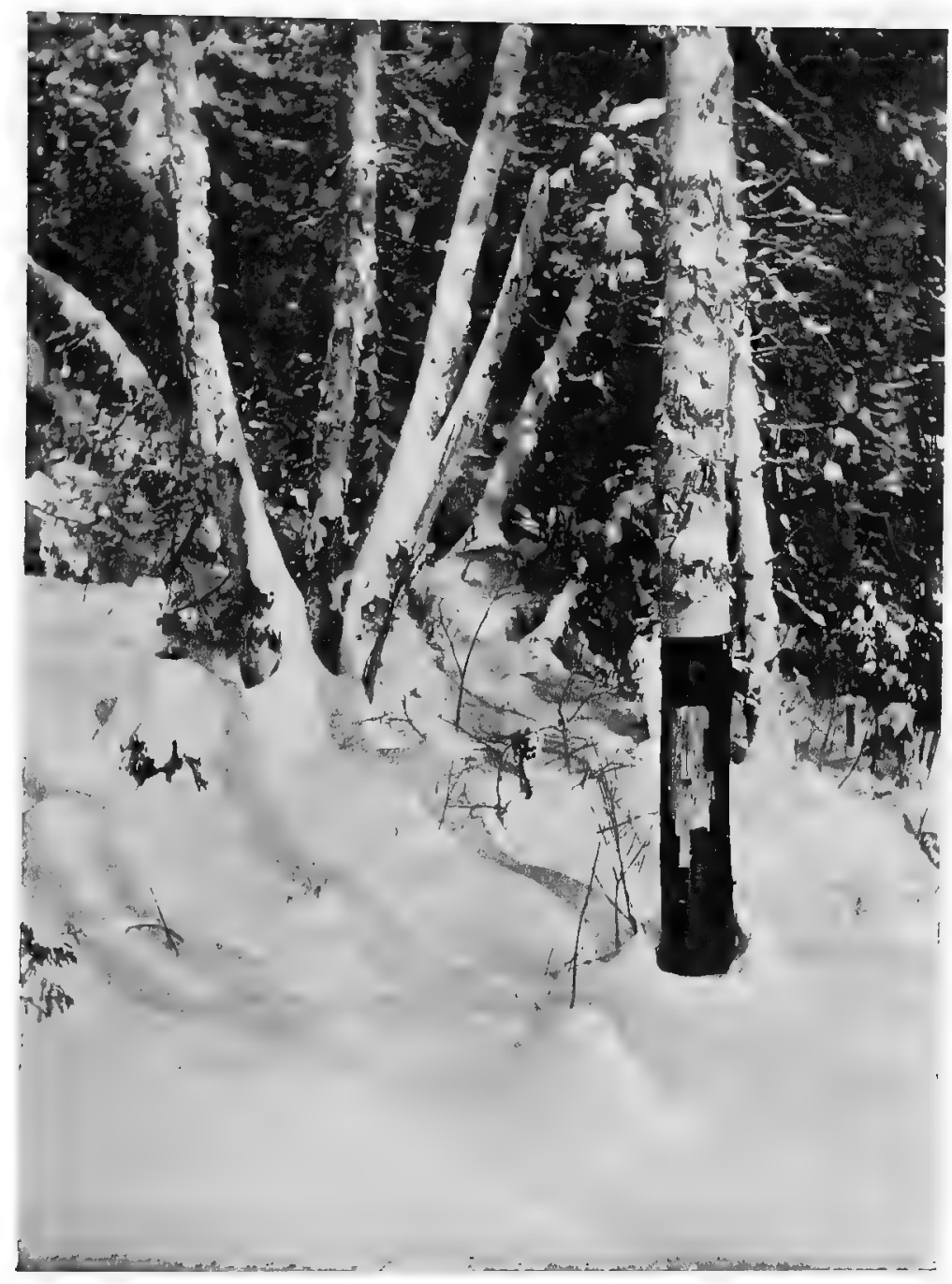

The Winter Woods. 


$$
\text { . }
$$


cottontail is hiding in some thick snow-covered scrub, or perhaps in a hole beneath an uprooted tree. Even the blood-thirsty mink cares not to venture forth unless sorely pressed by hunger. 'The ruffed grouse seeks the protection of a friendly hemlock tree, or sits snug under a thick patch of laurel. In the swamp thicket the quails, huddled close together for mutual protection, are trying to brave the storm, hoping no crust will form to keep them prisoners and let them starve slowly and miserably. With evening, the wind, tired out by its long day's work, quiets down and the snow no longer falls. Gradually the clouds disappear, and in their place we see the clear dark blue of the evening sky, dotted over with cold white stars. Then comes the quiet of the winter night, broken only, so far as we know, by the occasional hooting or crying of an owl, or the distant barking of a fox. But, though quiet, the woods are no longer dead, for it is during these still nights, unseen by man, that the tragedies of the woods occur. The morning dawns clear, cold and wonderfully still, a glorious morning for a tramp. If the ground is covered to a sufficient depth we tie on our snow-shoes, and enjoy the crunching sound, as we tread down the soft, dry snow. All the land is smiling, as though rejoicing that the storm has passed. The jewellike snow-crystals sparkle and dance in the cold white sunlight as the, sun rises higher in tho heavens, the colour of the sky increases until it becomes of a deep and rich blue, and no cloud breaks the great expanse. In the distance the mountains loom up with wonderful clearness. The 
trees on its slopes are sharply defined against the dazzling white of the snow, and like a fringe of infinite fineness the topmost trees edge the skyline. Here and there a hemlock or pine stands out clearly from its leafless brothers, as though in defiance of the autumn laws which denude the forests of their covering. Through the valley a river crawls along silently toward its destination. Against the white banks it seems almost black where the ice has not yet hidden its surface from our view. On either side alders and willows grow with roots submerged, and each twig, trembling as the water passes, is coated with ice, and spray-made icicles of crystalline purity shimmer in the sunlight. How different is this river from the one we had fished in during the warm summer days! Where are all the leaves and flowers which clothed its banks? Some of the flowers have sown their seeds for the next year's crop and the snow is protecting them from the severe frosts. Others, less eager, are holding their precious burden in tightly-closed pods, waiting for the days of snow to pass, that they may open their doors and bid the tiny seeds go forth and take root in the warming earth. The leaves, too, are fulfilling their part in the marvellous order of nature. Strewn about the roots of bush and tree they are giving back to the earth that which was required for their sustenance during the few months of their life. Of the endless variety of grasses and seeds scarcely any are visible; unable to hold the burden of snow they have lain down to take their long winter sleep. A few sturdy cat-tails hold their 
seed-bearing heads far above the snow, birds driven by hunger have loosened the silky seed, and it waits but for the wind to carry it off to other marshes, where it will spring up next year, to the delight of those who fortunately are never too old to enjoy gathering the rich brown velvet catkins. In the woods all is cold and silent. 'The snow, driven by the gale, has left the trees bare and desolate. It is the very picture of winter in all its bleakness. Were it not for the dormant buds of the azalea and some few trees that show a promise of life, we might easily believe winter to be a season of death. The only relief to the sombre greys of the tree trunks is the green of the laurel, the large drooping leaves of the rhododendron, and the welcome coniferous trees. Such is winter as we usually see it.

We are anxious to know what happened during the night, and so we make our way to the woods to see the stories of life and death which have been recorded on the spotless ground. The first thing we see is the lace-like track of a mouse; whether it is a meadow or a white-footed mouse we do not know. The tracks show where the little animal has run along on the surface for a short distance, then burrowed into it. By carefully cutting away the snow his burrow can easily be followed. It runs from root to root, and shows distinctly that the owner was in search of food. During the winter months the mice are well protected. They travel beneath the surface of the snow, secure from the eyes of their many enemies; occasionally one, more foolish than his companions, stays too long on 


\section{WILD LIFE AND THE CAMERA}

the surface and pays for his indiscretion with his life, for owls, hawks, foxes and others are always on the watch for them. Further on, when crossing a small clearing, we see the footprints of a red squirrel which has travelled rapidly from tree to tree. Unlike the mink and the mice, who drag their tails on the snow, the squirrel holds his well elevated, and leaves no middle track, as he runs with feet well separated. But the poor squirrel never reached his destination. His comfortable nest in the hollow branch will never know him again. The sign "to let" will in imagination be hung out to the first house-hunter passing that way. How do we know all this? See the tracks abruptly end at this point, see many curious, long tracks, as though someone had laid a queer-shaped fan on the snow. It is the track of the owl's wing, of the relentless hunter, keen-eyed and silent, who watches all the winter woods and fields. Without a moment's warning he has pounced on the unsuspecting squirrel and carried it off for his midnight feast. Soon we come upon the curiously large footprints of the cottontail ; he too must burrow beneath the snow, both for safety and for food. $\mathrm{He}$ takes no straight path, but winds his way in and out among the trees, scratching a hole here and there where his keen nose tells him he may find some root, twig, or leaf that is good to eat. Sometimes he stops as though listening, and the round blurred impression in the snow shows where his furry body had pressed it down. The listening had been in vain for poor cottontail, as we see later on. Not five feet from the rabbit's tracks are 


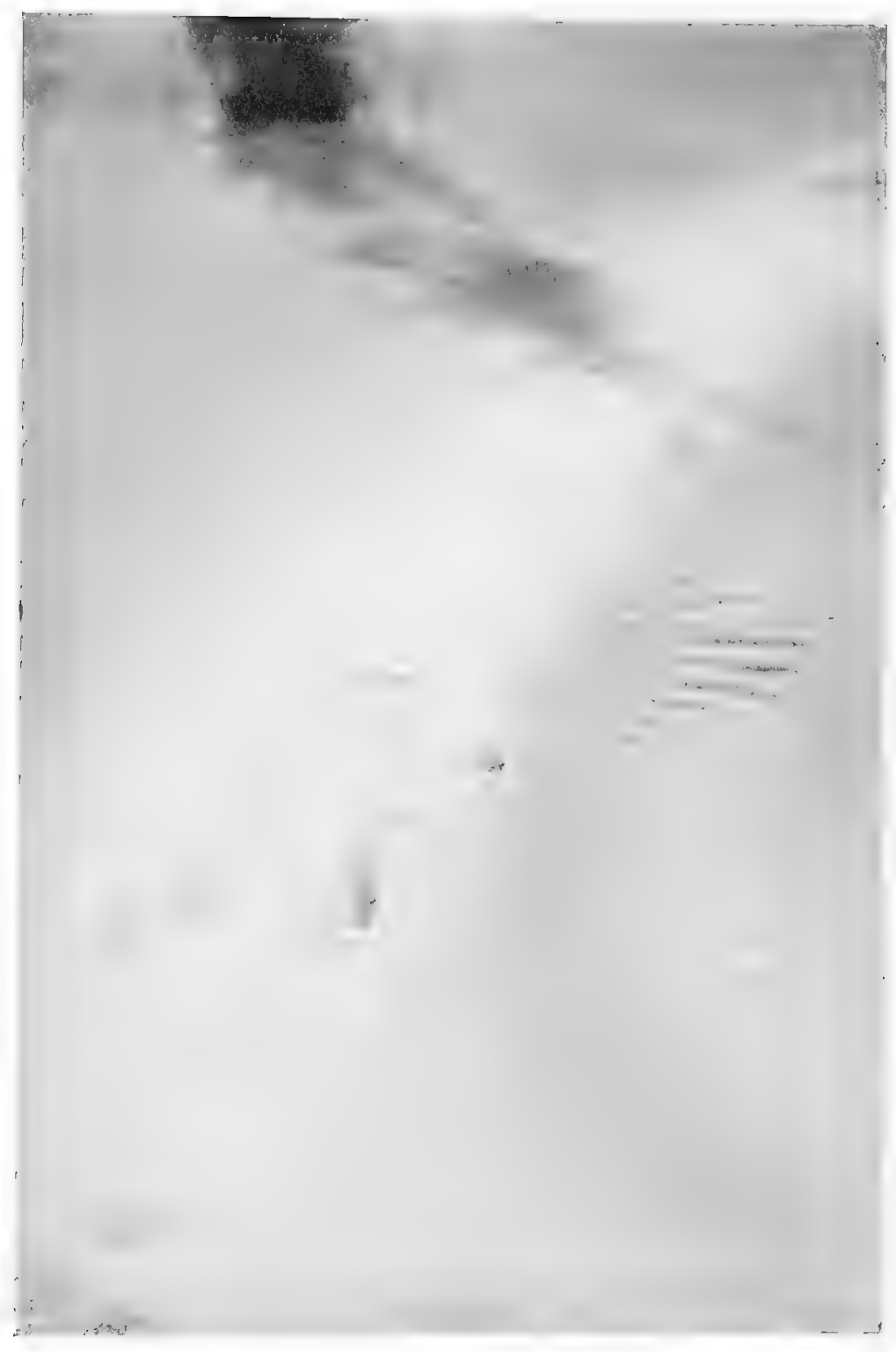

'lracks in the now. The deep footprints are thome of a ruirrel which was evidently canght by an uwl in a hawk, whone wing triteks are clearly shown. 
$-$ 


\section{THE HEAR'I OF WIN'TER}

the peculiar footprints of a mink. He walks as it were with his entire body, taking no steps such as other animals do, but bounding so that his hind feet land so near the fore feet that it appears almost like a single footfall. The tracks of the two animals converge until they meet, and show that the owners moved along the same road. The hunter and the hunted, the one suspicious but ignorant, the other keenly alert and dangerously silent. On they go. So long as the rabbit was feeding he was alert, and the cautious mink kept out of sight, knowing full well that to frighten his quarry now would be to lose a meal, for the rabbit would soon finish feeding and then make for some sheltered spot, where he would sleep the wakeful, restless sleep of the ever-hunted. Presently the tracks tell plainly that the rabbit has finished his dinner. As they lead in a roundabout way to the tangle of a fallen hemlock, the mink, with horrible cunning, knows what to expect, for he leaves the bunny tracks and goes by a different way to the hemlock. We follow first in the footprints of the hunted; they lead over a prostrate snow-covered log, then, after much stopping and turning, as though hesitating, to the densest part of the hemlock. We turn back to see what has become of the mink; his tracks lead past trunk and shrub, and show a certainty of purpose which bodes ill for the ralsbit. Gradually they approach the fallen hemlock, and we see that they, too, make for the dense cover. We fear the worst. A walk around the tree reveals only the small footprints of the mink. Poor bunny will never again leave tracks 


\section{WILD LIFE AND THE CAMERA}

for us to follow; his last track is but a tiny red stain on the glistening white snow beneath the hemlock twigs, and we pass on in silence, wondering at the ways of those who live in the woods.

In the winter we learn a little-a very little of the doings of the animals. In the summer, when the ground tells no tales, their lives are a mystery to us. For most of them our day is their night, and they only venture out when a kindly darkness hides them from inquisitive eyes. Throughout the winter there are stories told to us by the snow. At times it is soft and tells us all that has happened, even the movements of the winter birds. It points out where the ruffed grouse has eaten the scarlet berries of the bitter-sweet; where the goldfinch has hung on the dry sprigs of the golden rod and eaten of its seeds; where the less agile junco has searched for seeds in the thicket; even where the chicadee, that cheerful little acrobat of the forest, has torn the bark from a dead birch tree and destroyed the nest of some hibernating insect, and so perhaps saved for us some favourite plant or shrub which this insect and its young would have destroyed. All this and so much more that cannot be put into mere words are we told by the snow when it lies soft and white on the frozen ground. But there are days when the snow book is closed to us, and the secrets of the woods are not betrayed. These are days when a winter rain has frozen on each twig and bending blade of grass. Then we congratulate ourselves that we are living. The whole country is a fairy-land of glistening jewels that dazzle our 


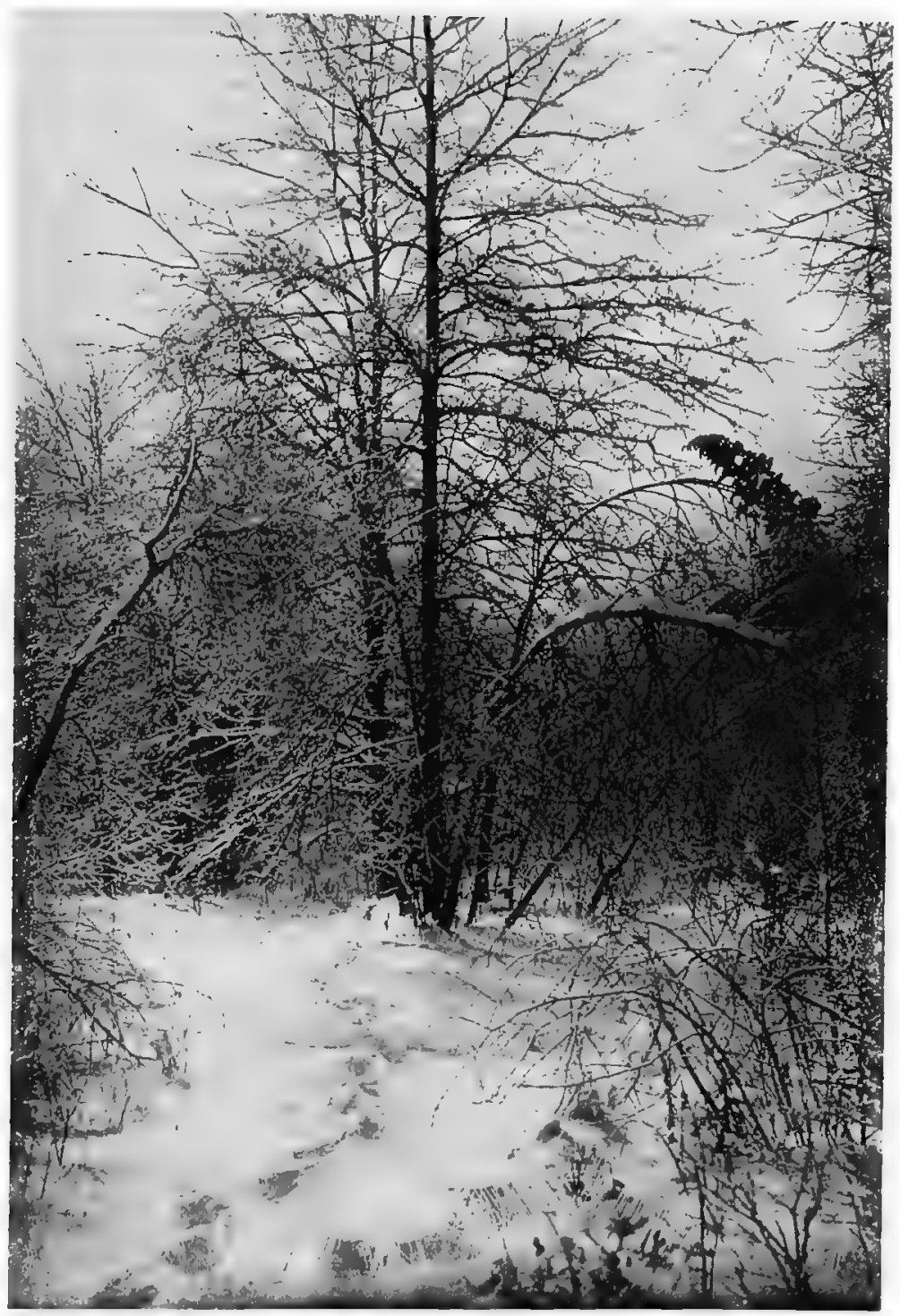

In the winter, when every twig is covered with a glistening cont of ice. 

eyes as they sparkle in the glad sunshine. All else is as nothing compared with these crystals. Even the scarlet berry of the black alder, which was beyond all things brilliant when the first snow covered the land, fails now to arouse our interest. Its colour is dulled by this new though perishable beauty. As we walk through the woods the frozen branches, shining wonderfully, creak and groan with their icy burden. A pair of blue jays alight on an oak tree, hoping to secure a meal of acorns. As they pull and tear at the frozen branches, the ice drops off with a noisy clatter that may be heard for quite a distance. When a breeze, however faint, passes through the woods, the sparkle increases a hundredfold, and the whole place resounds with the noise of the creaking ice. The snow-covered ground is strewn with long scooped-out crystals which shine like glass. It is wonderful: it is all beautiful, but it is all the great silent death spectre, and it tells him who knows the woods and fields that it is a deadly beauty, which ends the lives of birds in countless numbers, while it tickles our senses, for we are big and strong and well housed. Yet another phase of winter that has beauties of its own, greater and even more fleeting than the ice storm, is when the snow falls in large, wet flakes and settles on all things. Then each shrub becomes a snow bush and its branches are lost to view. Every stump and stone is a tall, white monument; even on the tree trunks the snow clings, as though anxious for all the world to be white. Then is it worth our while to leave our homes and at all cost to visit a forest of pines 


\section{WILD LIFE AND THE CAMERA}

or hemlocks, for they with their well-clad branches are wonderfully transformed; each branch is a study in itself, and the effect of the whole forest thus covered with snow is more beautiful than anything offered by all the glories of summer or autumn foliage. Strangely enough we do not feel the need of the stronger colouring, but are satisfied with the delicate blues, which are intensified by the almost gold colour of the thinlyscattered rays of sunlight that with difficulty find their way between the snow-clad branches. And yet, in all this beauty there is a certain bareness, a lacking of something indefinable, and almost against our will we long for the hopefulness of spring, when everything is pregnant with life. 


\section{MORE ABOUT WINTER AND THE TRACKS OF THE ANIMALS IN THE SNOW}





\section{CHAPTER XX}

MORE ABOUT WINTER AND THE TRACKS OF THE ANIMALS IN THE SNOW *

"The ground is all memoranda and signatures, and every object covered over with hints which speak to the intelligent." - EMrenson.

To him who would study the movements of wild animals, especially those of nocturnal habits, the northern winter must be a season of constant pleasure and interest. For at no time in the animal's life are his movements so clearly revealed as when the tell-tale snow covers the land. Unless there is a hard, smooth surface-crust no creature may venture forth without leaving tracks so clearly defined that even man, with his dulness of perception in matters connected with wood lore, can give a fairly satisfactory account of the animals' doings. The snow-covered ground is, in fact, an open book, on the pages of which are set forth facts which are absolute secrets during the greater part of the year. And yet how few persons ever avail themselves of these conditions. Do we not often hear people who profess to be nature lovers lament the, to them, insurmountable difficulties that interfere with their studying the lives of the animals? 'They declare that, with all their walking through woodland and swamp, they seldom, if ever, have the good fortune to see any

$$
\text { * First published in Country Life in America. }
$$




\section{WILD LIFE AND THE CAMERA}

animal except red squirrels, chipmunks, and such common varieties. The instinctive dread of man, resulting from his constant persecution, has of course led animals, especially the fur-bearers, to keep their tracks so well hidden that it is only in the most remote parts of the country we can hope to see mink, otter, and others possessed of valuable fur. Even in places where the only human habitation is the isolated trapper's shanty, the sight of a mink is rare, though the little creatures themselves may be fairly abundant, while in the vicinity of large cities one may scarcely expect to see anything more rare than squirrels, rabbits, woodchucks, and occasionally musk-rats. Yet, strange as it may appear, a considerable number of mink and others, as well as coons and opossums, are caught every winter within less than twenty-five miles of New York. I know of farmers who, living almost within sight of the city, add considerably to their annual income by trapping. These facts are given simply to show that even those who are compelled to live in, or near, a big town can, if they wish, find opportunities to study the ways of wild animals without having to go to the uninhabited districts.

The very best time to study the ways of all the terrestrial animals is when a light fall of wet snow has covered the frozen ground; then each footmark is clearly defined. If the snow is too soft the tracks are blurred, and consequently difficult of identification; if there is much wind the snow covers the tracks, or at least partly obliterates them, so it is advisable, if you would minimise your difficulties, to start as soon as possible after 


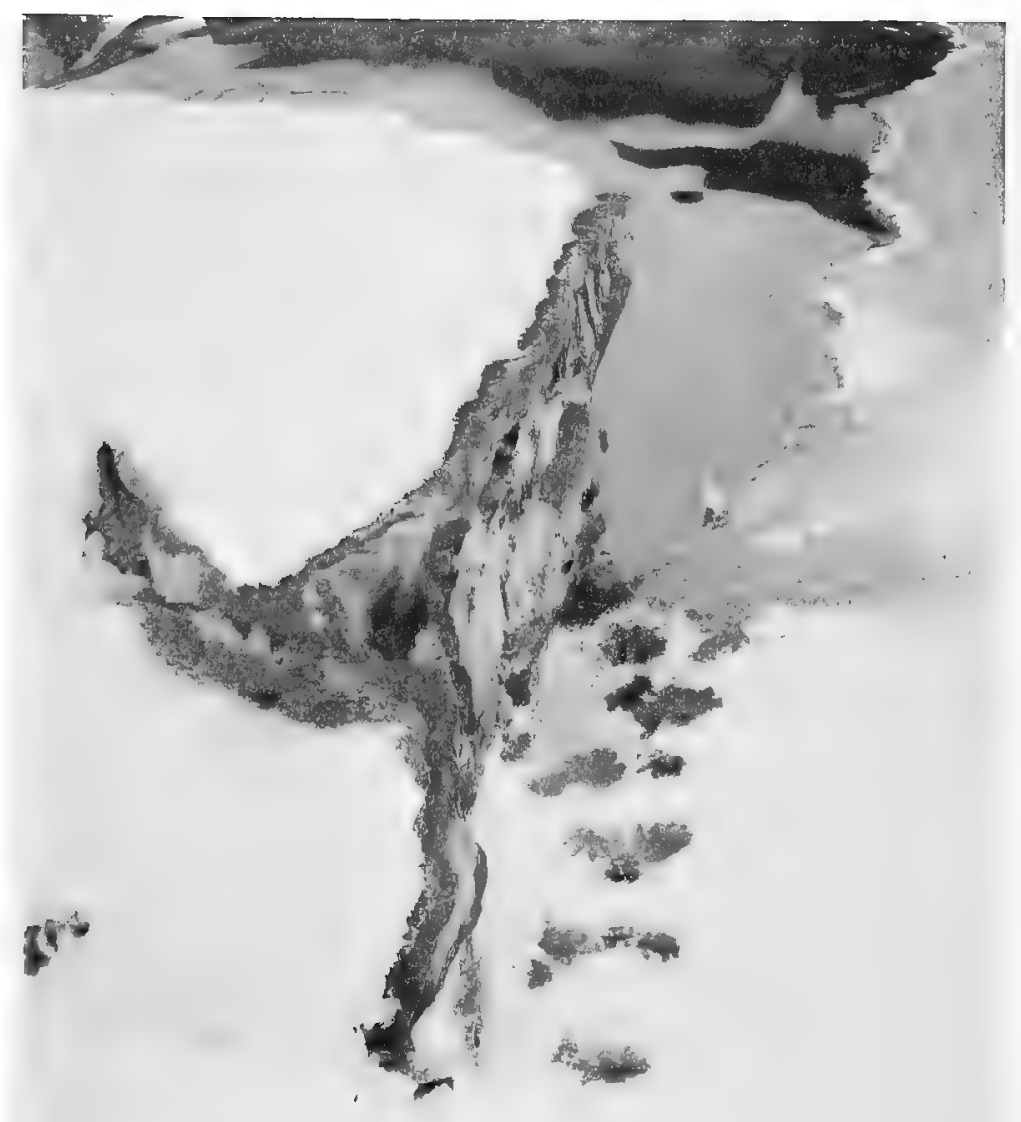

'Tracks in the snow slowing where a Musk Rat bis come from and ruturned to the water. 

the snow has fallen. The first tracks to learn are those which are most common. Do not scorn familiarity with the tracks of the house cat, and of the different kinds of dogs; a perfect knowledge of them may save you much mortification. A friend of mine spent hours in following the trail of what he thought was a fox; he was much disgusted to find it led to his neighbour's back door. Where a fox's and a dog's feet are about the same size they are not by any means easily distinguished. Some writers say that the fox's track is not nearly so clumsy as that of a dog, but that seems to be a purely imaginary difference; the only difference I have ever been able to discover is that the fox's footprints are, if anything, more nearly in alignment. As a rule a fox's gait is a stealthy walk when hunting, or a trot when pursued. The length of the step when walking is about one foot. But it must be borne in mind that all animals vary in their methods of walking and running according to the condition of the snow: deep, soft snow causing a jumping gait, even among animals which habitually walk or trot. If you have ever hunted a fox, and, as is usually the case, lost him, even with good dogs, let me advise you to take the first opportunity of following the tracks (in the snow) of a fox and the pursuing dogs. Your admiration for the fox will certainly increase, such clever manouvring as the wily animal exhibits will astonish you, and no longer will you feel ashamed of your dogs and of yourself at being outwitted. During the winter months foxes live principally on rabbits and mice, and if you follow a trail 
far enough you will usually see that where mice have been dug out of the snow, a ruffed grouse or a poor bunny has been stalked and killed by his most dreaded enemy.

The most numerous tracks in woods and fields in the region of civilisation are those of mice, shrews, rabbits, and white, red, and grey squirrels. Go where you will through woods, fields or swamps you will always find the tiny footprints of mice. They begin and end at a hole in the snow, showing where the little creature has left the kindly protection and risked its life in the open; usually his journeyings on the surface are very short, while sometimes one, more courageous than wise, travels as much as thirty or forty yards without burrowing. Under the snow they live in comparative safety, and when the snow begins to melt, their runs, forming a perfect network, are clearly visible. The mouse in its method of progression over the snow somewhat resembles a squirrel; its tracks therefore are much the same in form except that a fine line usually shows where the tail has dragged. Much smaller and more delicate than the mouse-tracks are the lace-like trails of the shrews, the smallest of our quadrupeds. One can seldom see their tracks very clearly, as it is only when the snow is in perfect condition that the fine footmarks are at all sharply defined.

The track of the "cotton tail," the common hare, or rabbit, as it is usually called, is unmistakable. Owing to the well-furred foot the track in the snow is never sharp, but even so, the large prints of the hind feet, which are placed in front of 
the forefeet, make the tracks practically certain of identification. Most people know that a rabbit's hind foot is larger than its fore foot, yet it is not at all an uncommon thing to see a man tracking bunny backwards, in other words, thinking that the sinaller fore foot tracks were in front of, instead of behind, the hind feet. When the snow is deep the hare burrows beneath the surface in search of food; these tunnels are often of considerable length.

A belief common to many people is that squirrels hibernate, but anyone walking through the woods can disprove it, for, even though he sees no squirrels, he will see the tracks in abundance. Chipmunks do hibernate in their underground homes, where they have great stores of food, but both grey and red squirrels lead a more or less active life throughout winter. This is made clear by the fact that much of their food is stored in the ground beneath leaves and rubbish. A certain very well known writer makes the statement that the red squirrel lays up no stores like the provident chipmunk, but scours about for food in all weathers; but this is by no means true. I have frequently seen a hoard of hemlock seeds which had been dug and eaten by a red squirrel in a part of the country where there are no greys. The tracks of a squirrel resemble to some extent those of a mink. When first I began looking at tracks in the snow I could only be sure which were which by following them up; if they began and ended at a tree I called them squirrels', if at a stream or swamp they were put down as minks'. This was a tedious way of doing 


\section{WILD LIFE AND THE CAMERA}

things and somewhat uncertain. The real difference between them is that the squirrel, like the hare, places his hind feet slightly in advance of his fore feet. But, unlike the hare, the footprints are scarcely separated. The mink when running does not arch the back very much and goes in bounds, landing the hind feet almost directly in the prints made by the fore feet. When the snow is deep they are often undistinguishable. If the mink has to go under any obstacle, such as a bent tree or a fence rail, instead of bounding, it walks, its body leaving a deep furrow in the snow, for its legs are very short. To follow a mink's track is usually to see the mute story of a tragedy. Just some trampled snow and a red stain. The whole method of hunting is told by the snow. We see how they follow a rabbit, taking every precaution not to betray their presence while the wretched creature feeds, for then it is alert; how they follow it, as described in the previous part of this chapter, to where it sleeps beneath a log, an upturned roof or the snow-covered top of a fallen tree, and then stealthily creep on their unsuspecting prey; how sometimes the rustling of a dead leaf warns the rabbit, who leaps forward, perhaps just in time to avoid the furious onslaught of the unlovable mink, though more often too late, in which case the red stain tells us that the rabbit has been eaten where it expected to sleep. All these things and so much more we are told by the snow. If only we will use our eyes we can learn more of the ways of animals in a week of good snow than many months or even years of summer. Should snow fall when the 


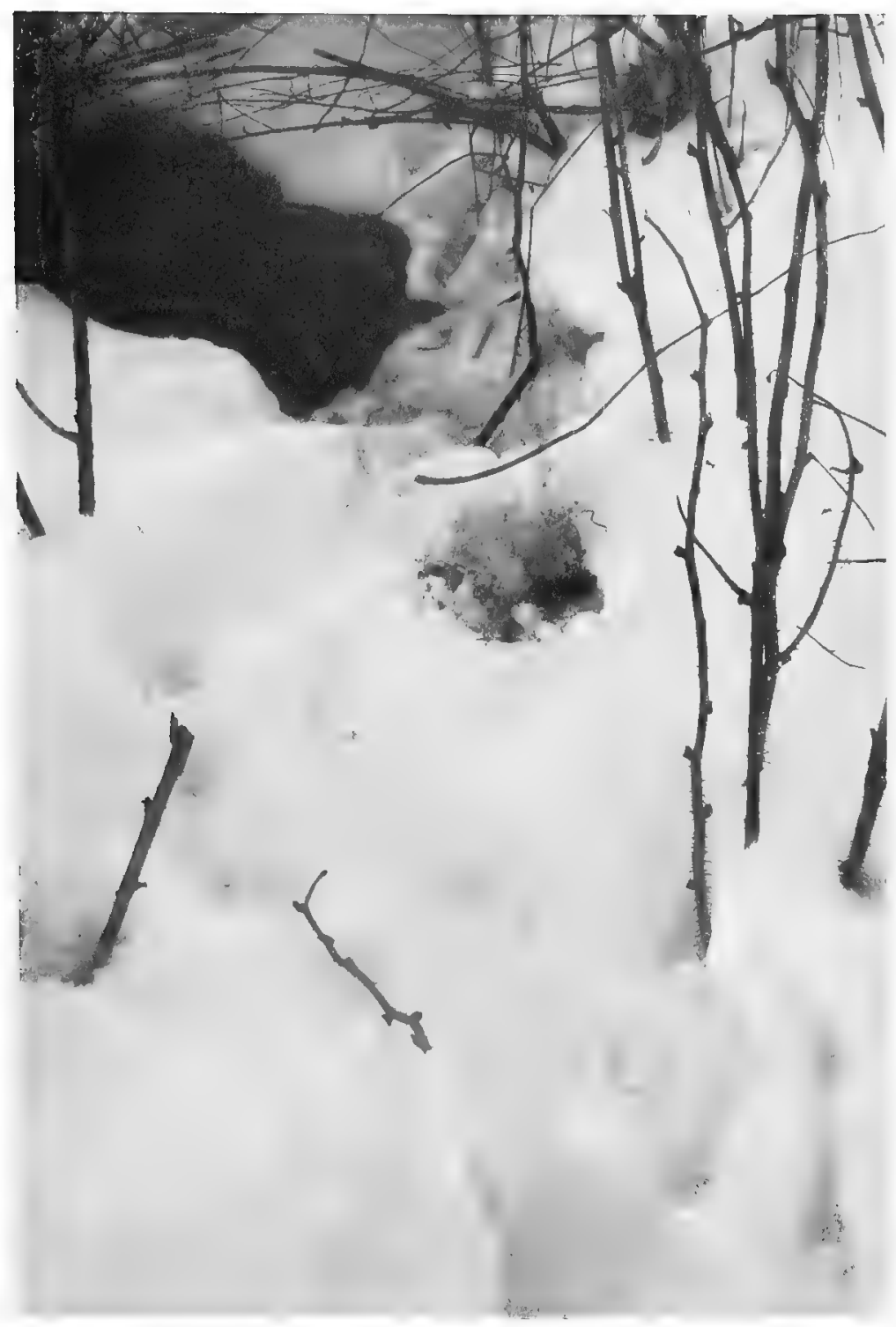

Thitcks in the simw, shuwing where a Mink has caught a Munk-lat an it antwerl trom a hole in the ice. 'The hark patch in the centre of the jicture is bluod. 

animals have their young, what havoc would be wrought among the weaker species by such creatures as the mink, the weasel or the fox. 'The home of the young would be revealed to man and beast. But, fortunately, few animals, with the exception of the mice and the porcupine, give birth to their young until after the treacherous snow has gone.

To give an accurate description in words of the forms of the various animals' tracks in the snow would be almost if not quite impossible, so subtle are the differences, and it seems best to advise anyone interested in the subject to visit a zoo on a snowy day, and then make mental and pencil notes while the tracks are fresh and there is absolutely no question as to by what animal they are made. Of course, where you have the good fortune to see a wild animal in its wild state and the snow is in good condition, take advantage of the circumstance by making a careful examination of the tracks, following to see whether they change much under different conditions. It is scarcely necessary to say that a knowledge of the form of the animal's foot is desirable. Such knowledge may be partially obtained from skins and mounted specimens in the museums, but, owing to the drying of the pads, no accurate idea can be gained of what the footprint is like except from the living or freshly-killed animal. A muddy day in a zoo will teach you more about the exact form of an animal's footprint than all the museums in the world. 



\section{THE LIFE OF THE TRAPPER}





\section{CHAPTER XXI}

THE LIFE OF THE TRAPPER,

THE MAN FOR WHOM COLD WEATHER IS A SOURCE OF LIVELIHOOD

OF all the means by which man makes his livelihood there is probably none that appeals more strongly to the imagination, especially of the growing boy, than the life of the trapper. Most boys at some time or other in their lives decide to throw off the yoke of civilisation and devote themselves to the life of trapping. They usually know absolutely nothing about it, nothing of the hardships, of the disappointments, of the years of training necessary, and of the inborn skill of woodcraft, without which success is not to be found. All they know is that the trapper is one who lives in a wide world of freedom, and whose life is surrounded by a veil of picturesque uncertainty. To be enveloped in this veil is the keenest desire of the boy gifted with that most precious of gifts-a healthy imagination. But the trapper's life is not all beer and skittles, not one long round of pleasure and success. Every pelt sold or exchanged is procured only after a vast expenditure of work, work that would make the ordinary labourer shudder. How little does the fashionable lady realise when she selects some fur that suits her fastidious fancy what that fur cost the man whose 
hermit-like life is spent in gathering pelts for the great fur markets of the world. And yet the trapper is a man to be envied, especially so if his country is one rich in fur-bearing animals, for then he can make a good living, and, greatest of luxuries, be his own master. The lives of trappers are all very much alike, varying chiefly with the climatic conditions in which they live. In Florida the life is seen in its easiest form, free from most of the hardships incidental to the cold country of the vast north, but then the profits are small, for the southern skins, being thinner, bring lower prices.

Let us follow a Canadian trapper during one year of his life, and we shall have some slight idea of the method by which he gains his living. When the nights begin to be cold and the maples in the forests show the scarlet danger-sign that warns the land of the approach of the awful cold of winter, and when the shivering poplars and silver birches throw off their leafy covering that they may the better be able to bear up against the heavy, clinging snows; when the beavers strengthen their houses, gather their winter supplies of food, and the squirrels collect quantities of nuts and seeds and cache them beneath the trees, then nature clothes all her animals with heavy coats of fur that they may be protected against the coming winter, and the trapper knows that the time has come when he must repair his log or birch-bark shanties, and take in his food supplies, just as the beaver is doing. Each man has his territory wherein he may set his traps, and if his claim be good it is undisputed. He may hold it for life provided he never leaves it 


\section{THE LIFE OF THE TRAPPER 299}

untrapped for three consecutive years. Should any other man place a trap on this land, he who has the trapping rights springs the trap and hangs it on a bush as a warning to the intruder. A line of traps extends over a distance varying from five to fifty miles. This line is not a line in the sense that some people imagine, for the traps are placed sometimes a mile or so apart, only the likelylooking situations being chosen, and these are usually in the immediate neighbourhood of lakes and swamps. 'The trail leading to the traps is usually blazed, for when the heavy snow falls the appearance of the country is completely changed and the trap would be lost if there were no sign to show its whereabouts. For each kind of animal a special trap is constructed. For mink a rough pen is made, usually at the foot of a tree; old wood is used for uprights and they are placed fairly near together; inside, a meat bait of any kind is suspended, and just inside the entrance to the pen the steel trap is set; small twigs are placed on either side sloping towards the pen, and often a piece of hemlock or spruce is laid on the outer side of the trap, so that the animal will have to jump, and the chances are he will land on the pan of the trap. Over the pen a roof is made of balsam branches, to protect the trap from the snow. For lynx the same sort of pen is used, except that it is larger and a noose of heavy fish line or wire is often used instead of the steel trap. Marten are caught both with the steel trap and the dead fall. For musk-rat it is necessary to place the trap beneath a rough shelter of branches on the ice where a hole has 
been made. The trap is attached to the middle of a stick, so that when the animal is caught and makes for the water, the hole in the ice not being large enough to allow the stick to pass, he soon drowns. For otter the trap must be set beneath water at a place where the current is swift enough to prevent the forming of ice. 'The water must be shallow, so that the otter will have to walk, and twigs are placed on either side of the trap, with the idea of leading the animal directly over it. As a good otter skin is worth to the trapper about eighteen dollars, it will be understood that no trouble is spared in arranging the traps, the result being that the otter is becoming very scarce in most localities.

Before the time for the first snow the trapper has all his traps set and has his cabin ready for winter. As a rule the cabin is made of hemlock or spruce logs, the crevices being well clinked with moss or other suitable substance. As heat is the all-important thing to be desired the cabins are made very sinall. The one shown in these illustrations belonged to a one-armed trapper who throughout the winter lives in the woods with his two dogs, large, smooth-coated St. Bernards, as his sole companions. The diminutive cabin, when $\mathbf{I}$ saw it, was so covered with snow that it was scarcely visible. Its tiny door, scarcely large enough to admit a man, even though he enter on all fours; the window not more than nine inches square, the old stove made out of a large tin canister, the single, small threelegged stool made from a single piece of hemlock whose branches happened to grow in the desired 


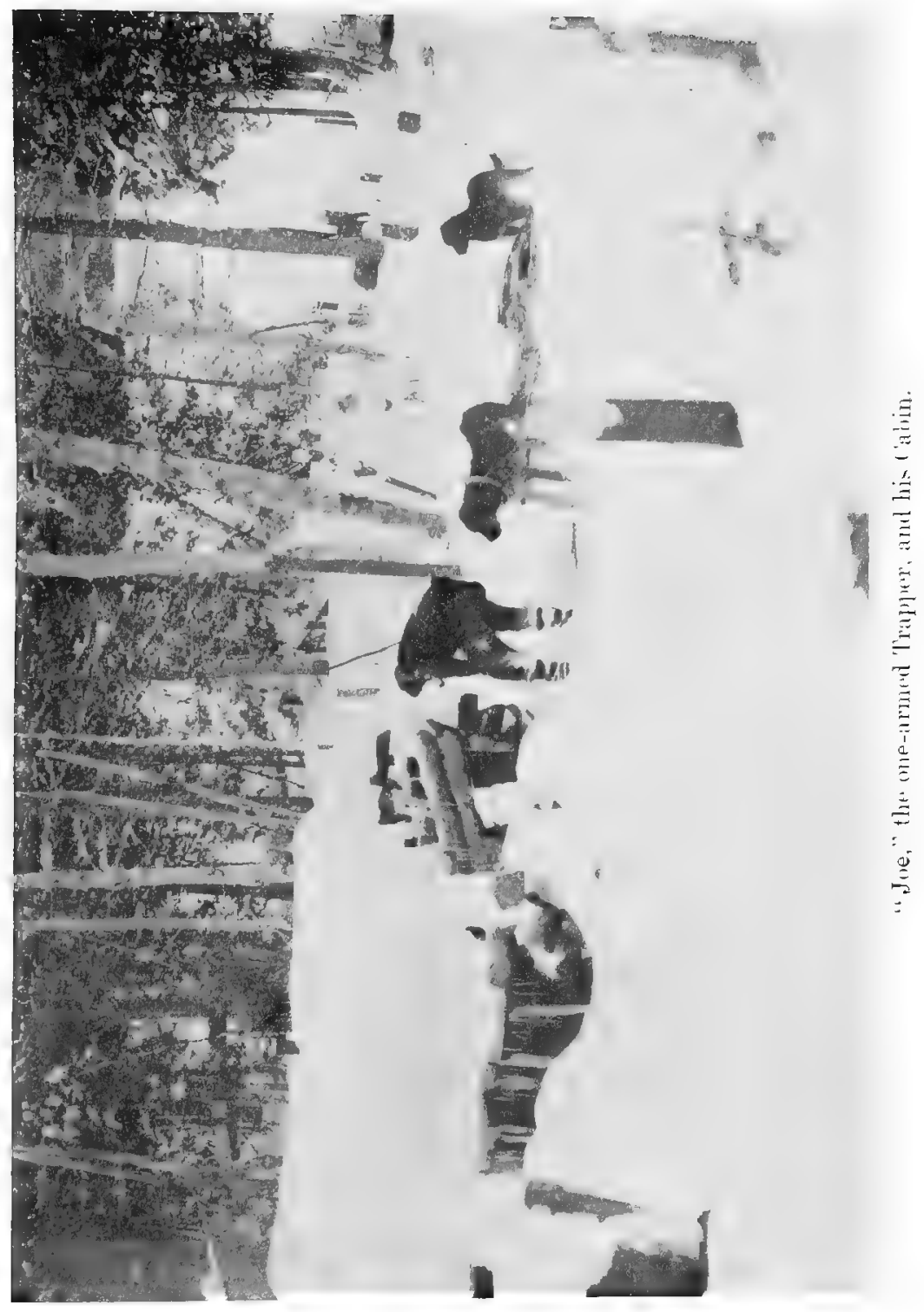




$$
\text { . }
$$




\section{THE LIFE OF THE TRAPPER 301}

way, the scanty cooking utensils and the bed of sapling covered over with balsam boughs, all bespoke poverty, yet the man, each winter, made from four hundred to five hundred and fifty dollars by trapping, and supported in comparative comfort his sister and old invalid father who lived in a cottage near the settlement. Joe had but one arm, yet he could use that one as well as most men can use two. Only when it came to washing his hand did he experience any great difficulty. His line of two hundred traps extended over forty miles of country, and every two weeks these had to be visited. At intervals along the line small cabins were built where, if necessary, he could spend the night, for the winter days in the north are very short and travelling on snow-shoes over soft snow is slow work. These outlying huts are, if possible, even more primitive than the one just described. Yet they answer all purposes. We can imagine Joe starting out on his round, too experienced a trapper to build castles in the air such as the novice delights in, for well does Joe know that unprecedented numbers of pelts are only taken from traps that are set in the lands of happy imagination. Should the day be fine and the snow in good condition, the task will be comparatively easy and he will be able to visit trap after trap in quick succession. Perhaps ten, twenty, thirty or forty may be visited and no animals found. In one, perhaps, the snow has drifted in and clogged the trap, and the footprints show that a mink has entered, eaten the bait, and left, satisfied with a full meal, asking no questions as to how it came there Then the trapper kmows 


\section{WILD LIFE AND THE CAMERA}

he has lost about four dollars. In many of the traps the bait has been eaten by the mice or weasels, but by far the greatest number show no sign of having been visited by animals. The virgin snow, that recorder of deeds, writes no word, and the trapper, after a single glance, passes on. Perhaps the result of the day's work may be but three or four musk-rats, whose skins are worth about eighteen cents apiece.* Then, as darkness sets in, he goes to one of the shanties, and, after a lonely and frugal meal of pan-bread and pork, lies on the floor close to the fire, and, before his pipe is out, has fallen asleep. The morning sees him up long before the sun. Making his toilet is a simple operation, consisting only of rubbing his eyes, perhaps putting on a dry pair of socks, and then lighting his pipe, and after a few mouthfuls of food he is off again. The day may not be fine as the day before had been. Maybe it has snowed all night and is still snowing, with a light wind blowing and a temperature of twenty-five degrees below zero. If so, the work will be more difficult, but he must tramp on. The sound of the snow-shoes as they touch each other at every step and the moaning of the wind in the tops of the evergreens alone break the frightful stillness of the snowbound country. The day may prove a more lucky one. Once Joe found two otters in a single trip over his line, but that was unusual and therefore a day to be remembered. Possibly he might find a cross fox (between black and silver, I believe), and that is good luck, but a silver fox is the best of all, for it brings the trapper

\footnotetext{
* This was in 1902.
} 


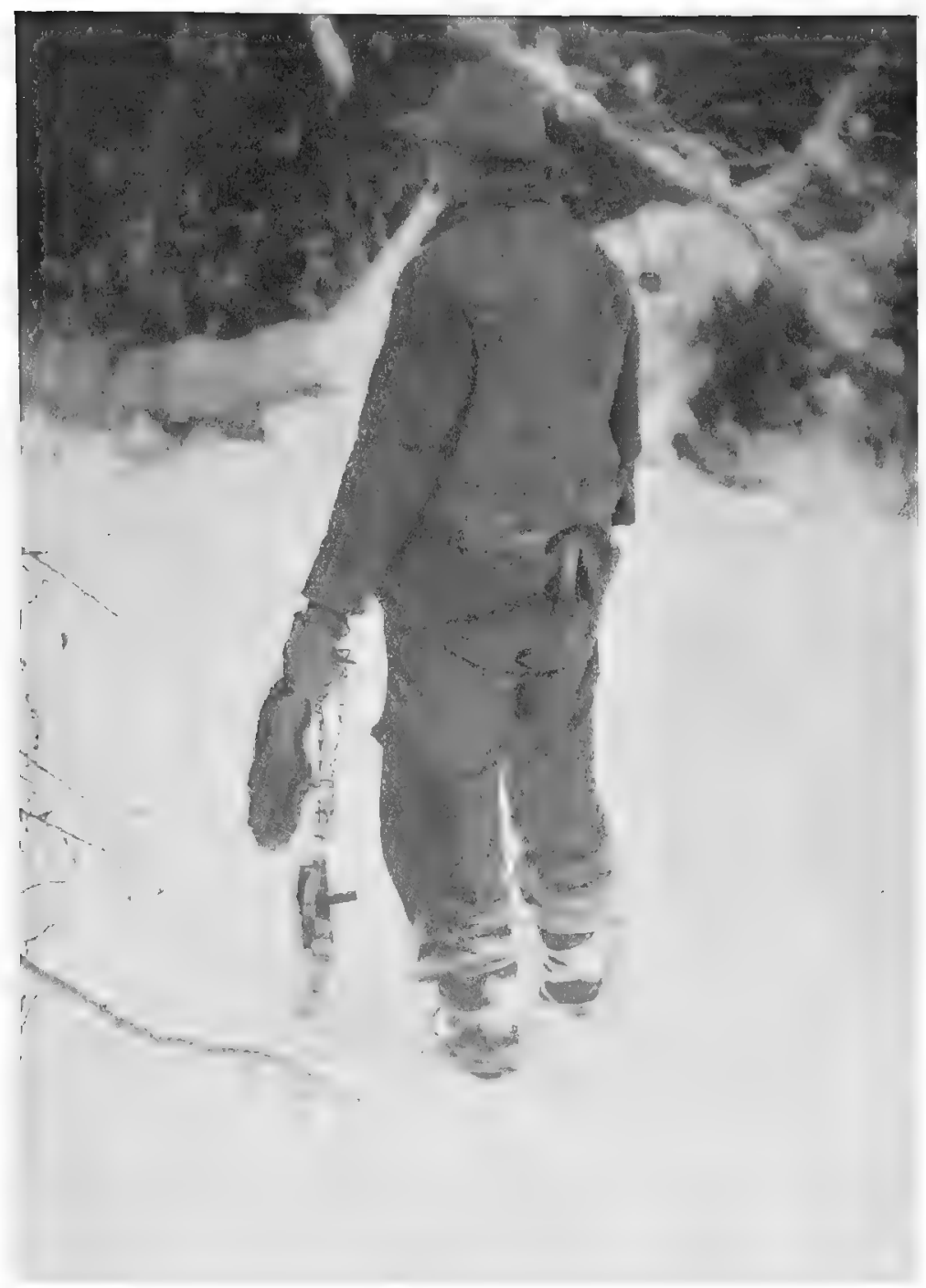

"Jue," the one-armed 'Trapner. 



\section{THE LIFE OF THE TRAPPER 303}

anywhere from fifty dollars to two hundred dollars (and sells at the fur sales as high as two thousand two hundred), but then, few of them are caught. An average trip along the line of traps would bring in from thirty to forty dollars, and most of these would be in mink skins. No trap would be used except during the trapping season, which lasts from September or October till March or April, when Joe returns to the settlement to dispose of his supply of pelts and buy provisions. The pelts are either sold or exchanged at the general store, or they are sold to the travelling fur-buyers, who visit all parts of the country, even in the most remote settlements, where they can pick up odd skins at low prices. The season ended, he goes to his farm if he has one, or perhaps he remains in the woods acting as guide to the stray sportsmen who happen to visit the district. A good trapper is usually a good guide, for he is thoroughly at home in the woods and knows much about the habits of animals.

Owing to the increased demand for furs and the absurd demands of fashion which require that fur garments be of different shape and style each year, the fur-bearing animals in their wild state are yearly becoming scarcer. So it is safe to conjecture that fur farms will in the future supply the markets and the trapper will be a man of the past, and those who come after us will then read of his life, and it will read like a fairy tale. As the large birchbark canoe, laden to the gunwale with furs, is passing down the quick-flowing river of time and civilisation, so, too, will the picturesque trapper slowly glide out of existence. 
. 


\section{CAMPING FOR ALL SEASONS}





\section{CHAPTER XXII}

\section{CAMPING FOR ALL SEASONS}

\section{Camping in the Cold}

He who camps during the warm summer months finds comforts in abundance and drawbacks scarcely noticeable; he who chooses the bright cool days of the waning year finds many things to enjoy, and only when the cold rains come does he meet with any of the disagreeable features of the fascinating simple life in the woods; but of all seasons for camping perhaps none offers the peculiar fascinations that are to be found when the land is clothed in its unspotted winter garb. Then the air is clean and clear, the woods are even more silent than when they are dressed in green, and the trees and shrubs are transformed by their wonderful white overcoats. On a bright day all things glisten, and the sparkling crystals seem to dance and laugh in the crisp cold sunlight, which illumines, but does not warm. The tree-top bends with its load of snow, and should the cold be very intense the strange, sharp sound of a frost-burst tree rings up the forest echoes. Then all is again silent, absolutely silent. To give up the warmth and other comforts of a home and take oneself off to the cold northern woods does not sound alluring to those who have not tried it. The inducements appear few indeed to the uninitiated, and he asks derisively where the pleasure comes in. 


\section{WILD LIFE AND THE CAMERA}

It is difficult to answer the question with mere words. To describe the delights of tramping through the snow-bound woods, equipped with well fitting snow-shoes, is not easy. Almost ghostly is the scarcely audible swish-swish of the snow-shoes as they pass over the firm dry snow. The keen air is bracing, so that your strength seems equal to any task. Where is the awful cold you have heard about? Surely the temperature is scarcely below freezing; and you remove your heavy woollen jacket. Then your woollen gloves feel over warm, and they too must come off. Wait just a minute and see what the thermometer has to show: $20^{\circ}$ below zero. Why, surely it must be wrong? But no, your fingers have frozen to the metal case, the perspiration changes to ice as it falls on your arm. Perhaps, after all, the mercury is right, for now that you have stopped exercising you really do feel that the cold is intense. When the air is so dry it is very deceptive, and not until your fingers freeze do you appreciate the cold.

The first thing necessary for comfort when on a camp trip in the snow is proper clothing for day and night. Men accustomed to the cold will sleep before a large open fire and have no blanket over them. It is not advisable for the man accustomed to steam-heated rooms to attempt this. A good sleeping bag made of four thicknesses of light-weight pure wool blanket with an inner bag of natural wool bating covered with thin flannel is all that is needed, but on no account use any bag that laces at the lower end. These laced bags are good enough for temperate weather, and they have the advantage of 


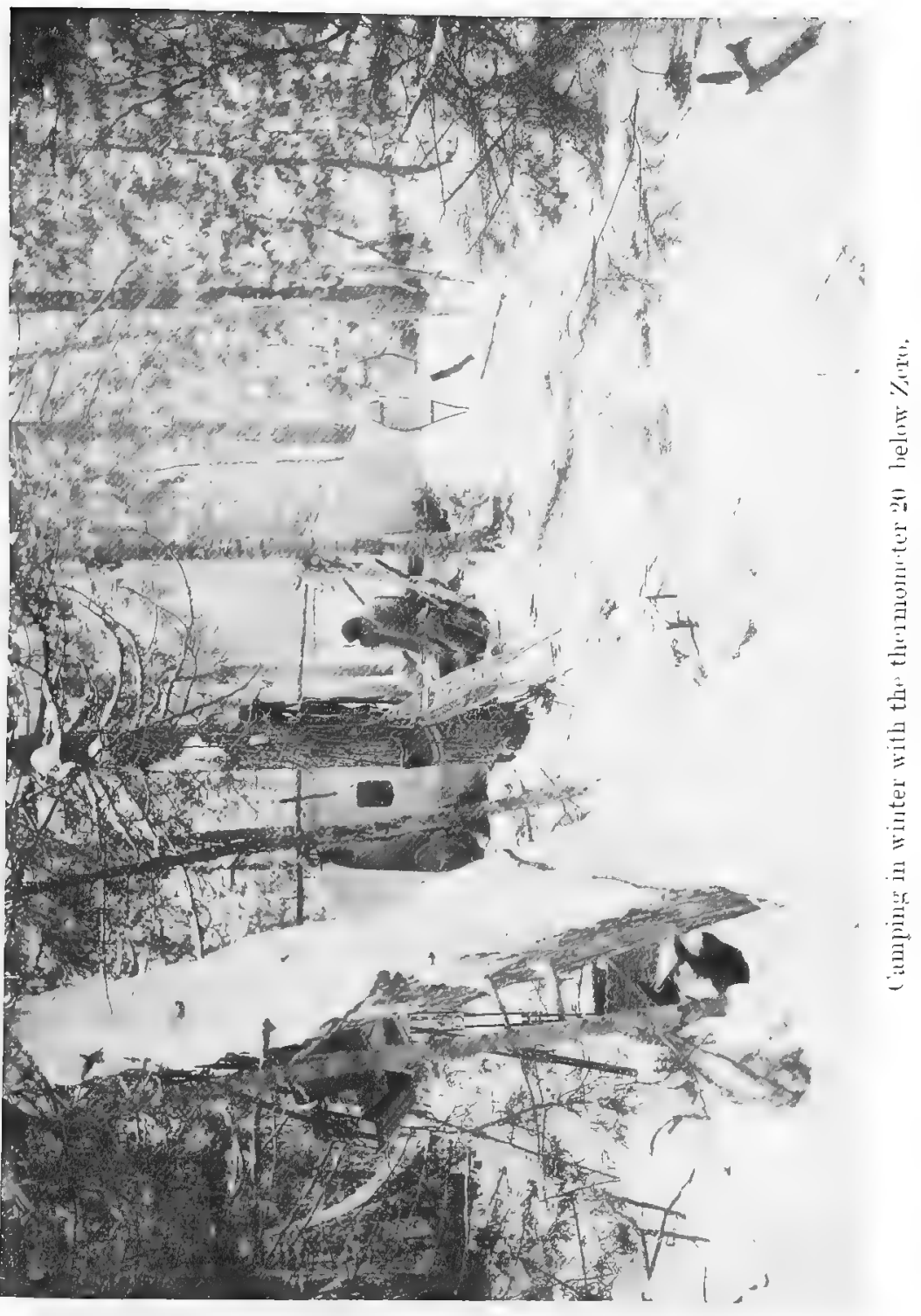





\section{CAMPING FOR ALI. SEASONS 309}

being easily aired, but they allow too much cold to enter, so for cold weather they are not to be recommended. A light-weight waterproof outer covering, though not absolutely necessary, is by no means to be despised. Heavy, loose-fitting, or, better still, many suits of large thin woollen underclothes, loose woollen stockings, and a toque cap complete the necessary sleeping outfit, to which a loosefitting sweater may be added in case of very cold weather. In the way of clothing there are many differences of opinion as to what is best. Some people contend that a suit of linen mesh underwear should be worn next to the skin, covered by one thickness of very heavy wool, a thick woollen shirt and homespun outer clothes, to which the inevitable sweater should be added; while others think it best to wear three suits of light-weight loose woollen underwear, instead of the one heavier weight and the linen mesh. Whatever underwear you take, be sure it, as well as your other garments, is of ample size; tight clothing is cold clothing, and, besides being cold, it interferes with the freedom of one's limbs. Two pairs of heavy woollen stockings should be worn, and of course with snow-shoes moccasins are the only thing. These may be of "beef," buckskin, or green moose hide with the hair on; the "beef," oil-tanned, are excellent, being waterproof and strong. The buckskin is soft and strong but porous, so that if the snow happens to be at all wet you will be sure of damp, and consequently cold feet. Cloth-lined rubber shoes such as the lumber men wear are handy for use around camp, but they should not be worn with snow- 


\section{WILD I.IFE AND THE CAMERA}

shoes, as they cut the webbing. For head-gear a broad-brim felt hat or the toque may be used. The former is useful in going through the woods when the branches are snow-laden, as it keeps the snow from sifting coolly down one's back. In very bad weather a woollen cap, which covers the head, neck, ears, and cheeks, is a great comfort, as it keeps the driving snow from stinging one's face, and will usually protect the ears from freezing. Such a hood is also comfortable for a nightcap. Do not on any account carry anything that is not absolutely necessary. Snow-shoeing trips are not like canoe trips. In a canoe a few pounds more or less make but little difference, but on the snow, whether you have a dog-sled, or draw the pack yourself, you will find that extra weight counts in an alarming way. A well-filled pack-basket, which could be easily carried under ordinary conditions, would prove discouraging when the snow is in good condition, and impossible if the snow should happen to be deep and soft, so I repeat, throw out all unnecessary things and be liberal in determining what things are unnecessary. In the way of shelter, a light-weight tent is useful, though not absolutely essential. It should be in the form of a lean-to with no front, something like a reflecting oven. The lower parts must be well embedded in the snow to keep out draughts. A large fire directly in front will throw enough heat into the tent to keep a person warm even in the coldest weather. If the party is large, put the tents end to end, and have one long or two smaller fires in front of them. But do not on any account place two of these tents 


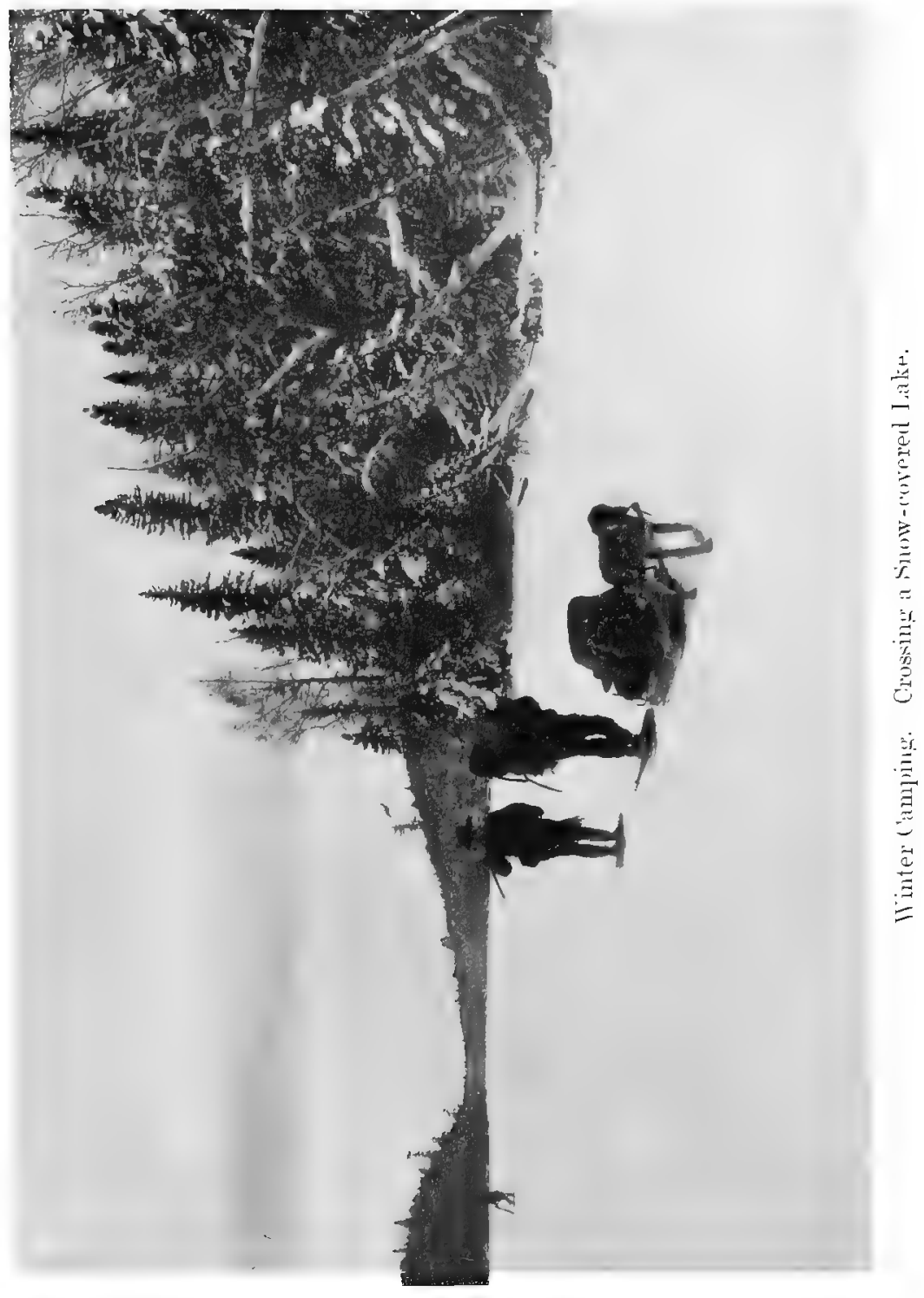


one on either side of the fire, for by doing so a funnel is formed and nearly all the heat goes upward and is lost. I once saw a camp formed in this way and spent the night in it. So great was the cold that our coffee froze within a few minutes after it was poured out, while within four or five feet of a huge fire, and in the back end of the tent the temperature was many $(18, I$ think) degrees below zero. Pancake batter had to be mixed with nearly boiling water and held near the fire all the time to prevent its freezing. Such a camp had little in the way of comfort to offer. Should sparks fall on the tent, sprinkle it on the outside with water which freezes and makes the cloth practically fireproof. When no tent is carried, a shack may be made of bark or boughs, which, if covered with snow, will keep the wind out and the heat in. In the event of a heavy fall of snow precautions must be taken to prevent the tent giving way beneath the weight of the snow. A rough structure of boughs over the tent will have the desired effect.

A most important part of the outfit is the food, for so much depends on the proper selection and quantity. Do not go by what some precise-minded man says. He works out the problem theoretically with mathematical precision for which you generally have to suffer. I once was a victim of such system, and now I carry what I think will be sufficient and not what somebody else knows will be enough. In cold weather one's appetite is usually keen, and in order to keep out the cold a full stomach is very essential, and, I may add, 


\section{WILD LIFE AND THE CAMERA}

comforting. In making out the provision-list do not ever think of canned foods, except the unsweetened condensed milk (I have never known it to freeze); canned meats are luxuries which are heavy to carry and cumbersome to pack. Whenever possible, put all provisions in strong muslin or paraffined cloth bags, and pack these in waterproof canvas bags of convenient size for carrying. Cooking utensils of aluminium are the only suitable kind, not only on account of their lightness, but because they will not burn. An outfit of good quality should, with care, last a lifetime. It is well to remember that all trace of either salt or ashes should be carefully removed before the utensils are put away for any length of time. In selecting an axe, which, needless to say, is an important part of the outfit, choose one that is light and has a long handle, and be sure that it is tempered to suit the cold weather ; an axe tempered for southern countries will fly to pieces when used in a very cold climate.

As the camera is an almost invariable adjunct to the camper's outfit, a few words of caution in regard to the care of it may not be amiss-above all things keep the camera and the plates (or films) well away from the fire, as the slightest warmth will cause moisture to condense not only on the lens, both inside and out, and working parts of the shutters, but also on the plates or films, and this moisture will freeze immediately the camera is removed from the influence of the fire. If glass plates are used, do not dust them with a brush when filling the plate-holders, as, owing to the dryness of the air, the electricity that is generated by the friction 
will cause all particles of dust to be drawn to the films ; so it is better either to leave the plates undusted, or to gently (and dryly) blow the surface. If a tripod is used, and it is by all means recommended, the length of the ordinary legs will be found quite insufficient, owing to the depth of the snow; an extension leg of about two feet in length will prove of the utmost value, or, better still, have small light discs, about four or five inches in diameter, which should screw on to the end of the tripod legs. Those will act as snow-shoes and prevent the legs sinking too deeply in the snow. Keep plates or films in a waterproof bag, and let the bag be buried in the snow when not in use.

\section{Camping in Summer.}

WHEN the trees are in full leaf and the days begin to be warm most of us talk of what we will do during the summer; how we will spend our holiday. Each one has some particular idea of how a summer holiday should be spent. One prefers the sea-shore, another a regular summer hotel in the country, and many take long trips on bicycles or in boats. Comparatively few even think of camping; the crudest country boarding-house or the much caricatured farm-house which condescends to be inconvenienced by summer guests for a paltry consideration of $\$ 10$ per week ( $\$ 5$ would be more than ample) seem to the uninitiated better than camping, and they put up with uncomfortable and often unclean beds, stuffy rooms, and poor food without a murmur. Why do they not take a good tent, or several if the party is large, and go to some suitable 


\section{WILD LIFE AND THE CAMERA}

place and there enjoy the summer? The cost of an outing of this kind, if divided among a few friends, is very small, while the pleasure and benefits to be derived from being in the open air so much of the time are, of course, beyond words. Almost any degree of comfort may be had in camp life when one is near a village, and, while roughing it appeals strongly to some of us, it is by no means necessary. Why so many people insist on using tin cups and spoons and steel forks when camping I have never been able to understand. They would not use them at home; even the idea of it would be repulsive to their delicate taste. Then why not carry plated forks and spoons into the woods? They are no heavier, are more easily cleaned, and have, so far as I know, no drawback; enamel iron cups and plates are a trifle heavier than tin. They are also more desirable. Wooden plates are sometimes used by those who have little love for dish-washing, but as the cooking utensils have to be washed, very little labour is saved by using them. In order to make a tent absolutely comfortable, a board floor should be laid. It costs very little, and is worth any price. As a rule a carpenter will lay it for a small consideration if he can have the boards after you have finished using them. It is best to have the boards planed on one side. Otherwise it will be necessary to lay a canvas floor-cloth, on account of the splinters. In pitching a wall tent it is best not to use the regular tent-pegs, but drive a strong stake (which should be at least a foot higher than the wall) in at each corner. To these stakes two poles should be fastened on each side of the tent, 
one for the tent grip, the other a foot or two above for the fly, a necessary thing in hot weather. In this way you do away with the long grip ropes, over which everyone trips, and as they shrink and stretch continually, according to the amount of moisture in the air, they are a constant source of annoyance. Around the tent a shallow ditch should be dug, otherwise the drip from the roof during a heavy rain will form pools under the floor. If no fly is used it is well to remember that nothing must come in contact with the tent roof. A leak will result if this is forgotten. In the way of beds there is nothing much cheaper or more easily transported than a folding canvas bed. These require no mattresses, and are therefore comfortable for summer use. If you sleep on the floor, a mattress is more or less necessary, but it is more cumbersome than the folding bed. Of course if you are camping in a place where balsam or fir is abundant, then use the tips of the branches, and no better bed need one wish for. Some people carry folding tables and chairs with them; these are comfortable, but by no means necessary A plank placed on two boxes will serve for a bench, and several boards laid together are good enough for a table. Folding tables are small and usually expensive. Two hemlock boards, 12 inches wide and 7 feet long, cost but a trifle, and will answer better than a folding table costing six or eight dollars. For cupboards, packing-boxes, with their lids arranged as shelves, are most convenient. A piece of clean cloth will serve as a door for those who are very particular. We all associate a large open fire with camp life. 


\section{WILD LIFE AND THE CAMERA}

A pile of huge logs burning and crackling, with pots hanging over it, is, of course, the only thing when we camp in the wilds, but near civilisation there is the difficulty of obtaining wood, and anyhow an open fire is not nearly so convenient as a stove for cooking purposes. Especially is this true during the warmer months. For practical use there is nothing much better than an oil stove, which should be used in a tent and sheltered from the winds. In case you are bothered by mosquitoes, nets over the beds are almost a necessity, but as it is nearly impossible to make a tent mosquito-proof, a smudge should be placed in a suitable place. A smudge is easily made of woods, chips, pieces of bark, leaves and grass, placed in a tin bucket or can. Be sure not to leave this where it can set fire to the tent, in case it bursts into flame. The best prevention for mosquitoes is to find a place where they are not. To insure comfort it is absolutely necessary to place your camp as near as possible to the water supply. It seems easy enough to carry a pail or two of water two or three hundred yards, but after a time you will come to the conclusion that a tenth of the distance is ample.

A very delightful way of spending a few weeks is to go either alone or with some thoroughly congenial spirit, taking all your belongings in a packbasket. In this way, if your load be not too heavy, you can go from place to place with comfort, camping where you will. A few days can be spent with the greatest possible pleasure along a trout stream, away from habitations ; but do not depend altogether on trout for food; if you catch many you soon 
become tired of them, and there is always that delightful uncertainty which is the great fascination of the sport, but which would lead to a slender meal ; and such a thing is not to be desired in camp. The outfit necessary for a short summer trip should not weigh more than fifty or sixty pounds. Some of the items are:-

Tent of the pattern shown in the lbs. illustration, large enough for two persons

Sleeping bag of light wool blankets 10

Rubber or waterproof canvas sheet, about . . . . . 4

Change of underclothes and extra stockings . . . . . 4

Cooking utensils of aluminium, two kettles, fry-pan, coffee-pot, folding baker, plate, cup and bowl, knife, fork and spoon . . . . 5

Fishing-rod and tackle . . . $1 \frac{1}{2}$

Light axe, with long handle . . 3

Food for one week, per head:-

Bacon, $3 \frac{1}{3}$ lbs. ; flour, 8 lbs. ; cornmeal, 3 lbs. ; rice, 2 lbs.; butter, $1 \frac{1}{2}$ lbs. ; lard, $1 \frac{1}{2}$ lbs. ; sugar, $1 \frac{1}{2}$ lbs.; cereal, 2 lbs.; baking powder, $\frac{1}{2} \mathrm{lb}$; condensed milk, 2 lbs.; coffee, 1 lb. (or tea, $\frac{3}{4}$ lb., or chocolate, $\frac{1}{2} \mathrm{lb}$.) ; dried fruit, 2 lbs. 28

'Total . . . 59

To this may be added a can or two of meat, even chipped beef, or codfish. 


\section{WILD LIFE AND THE CAMERA}

For two people the weight for each individual is of course less: one tent, one axe, and one set of cooking utensils being enough. The quantity of food is rather less, as there is less waste. With such an outfit one can live in comfort for a week if no fish are caught, while the addition of fish will make supplies last for another ten days. A trip to the nearest village can be made at any time to replenish the supplies. To those whose tastes run in the direction of nature studies, a camera is almost a necessity. A 4 by 5 size is large enough, and it should be of the long focus type. Roll films may be used, but either cut films or glass plates will be more satisfactory, and will be worth the trouble of carrying.

\section{Winter Camping in Florida.}

IN the winter months, when the cold winds howl through the streets of the northern towns, when the streets are ankle-deep in slush, and when all the country about us is clothed in white, and the leafless trees are pencilled strongly against the darkened sky, then our houses are heated almost to fever point by steam or hot air, and we long for the genial warmth of the south. Its bright days and its lazy climate act as a lodestone, and we leave the cold bleak north and, if we are wise, we go camping in that winter paradise, Florida. Nowhere can we find more pleasure than in this land of palmetto and sand, and nowhere are fewer difficulties to be met with. People talk of snakes and mosquitoes and shudder at the very idea of sleeping on the ground in such a pestridden country. How little do they know of the real conditions! Snakes there are, 'tis true, but 


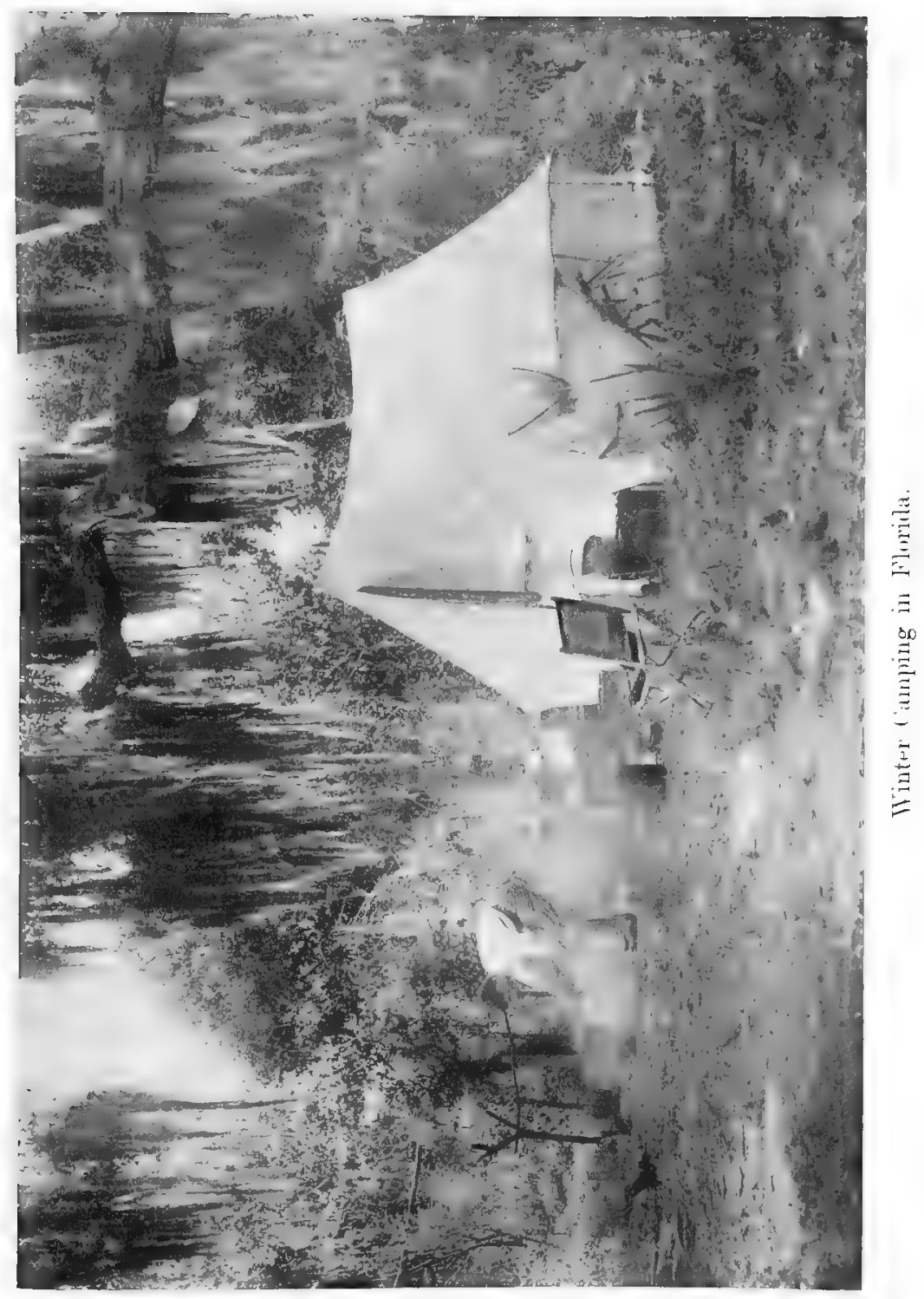





\section{CAMPING FOR ALL SEASONS 319}

how many authentic cases of deaths from snake bites do we hear of? As compared with the deaths from trolleys or from fire they are as one is to one million, yet people walk boldly in front of a trolley and light fires daily with no idea of the awful risk they must surely be running. But camp in Florida, the land of snakes! No, never!

I have spent many months camping in this terribly dangerous country, sometimes with and sometimes without a tent, sleeping in all sorts of places, shooting in swamps and in pine-lands, and two rattlesnakes only have I seen (both inside a city limit). Moccasins are common in places, but so slow are they in their movements that they need cause but little fear. As for mosquitoes, about which one is always asked, excepting along the coast they are seldom noticeable. A net to cover the bed may be carried, but it will seldom, if ever, be needed. More troublesome than mosquitoes or snakes are the turkey buzzards; these winged scavengers are at times a positive nuisance. Nothing in the way of meat is safe from their searching eyes unless it is carefully covered. So it is well to be provided with a few cheese-cloth bags of different sizes in which meat of any kind may be secured.

There is but one drawback to Florida camping, that is the difficulty of obtaining good drinkingwater. In some of the rivers, as, for example, the Kissimee, the water is good, and, strange to say, cold. But in many it is extremely doubtful. Curiously enough, the very clear water is usually the most harmful. Away from the rivers very fair 


\section{0 WILD LIFE AND THE CAMERA}

water may be obtained from the sand flats. These are sandy depressions of sometimes many acres in extent in which the rain water collects. By way of precaution it is usually best to boil and filter the water before using it, if there is any doubt as to the quality. There are three principal ways of camping in Florida: driving with outfit to suitable ground, canoeing or boating, carrying complete outfit, and house boating, if this may be called camping. Each has its own advantages. Where one doesn't wish to change constantly and there is a really good place, it is easy and satisfactory to be driven or carried by steamer to the spot, and there make a comfortable camp. If necessary have fresh provisions brought once in a while. In this way I have spent weeks camping by myself not far from the everglades, fifty miles from the nearest villages, and once a week a man came with his wagon and renewed my supplies. Travelling in one's own boat, be it canoe or flat-bottom boat, is delightful, and has the great charm of making one feel extremely independent. Owing to the shallowness of the water it is well to have a boat of very light draught-not more than four or five inches. The house-boat is comfortable of course, but its range is so restricted that it is scarcely to be recommended except in certain favourable localities.

The few things necessary to one's comfort in so genial a climate constitute one of its greatest charms. In the way of clothing all that is needed is just what light things we use during the summer months, with the addition of one warm suit of underwear and a sweater. These are necessary only in case of 


\section{CAMPING FOR ALL SEASONS 321}

a norther, when the teinperature falls very suddenly to freezing point or thereabouts, and the change, coming as it does at a few hours' notice, makes one very sensitive to the cold; warm clothing will therefore be most welcome. Any ordinary footwear will answer, but it is not advisable to use expensive waterproof boots, as the scrub palmetto, with its saw-like edges, will cut the leather. Rubber hip-boots will be found useful for those who object to getting their feet wet. Heavy canvas leggings protect one's legs from the palinetto and are therefore to be recommended. Unless you expect to camp in swamps, it will not be necessary to burden yourself with air mattress or any other kind of portable bed. If you are in a palmetto country, the palmetto will make a bed fit for anyone. Either the scrub or cabbage variety answers almost equally well. 'To make the bed, gather a number' of the leaves, split them into several parts, and lay the pieces smoothly to a depth of six or eight inches. The result will be a springy cushion equal to, or better than, a well-made bed of balsam boughs. Should you not be able to find palmetto, use Spanish moss, tearing it apart very thoroughly to avoid lumps. This, if carefully arranged, makes a comfortable bed, but it should be aired every day. A waterproof sheet laid over either of these beds is advisable and, as Florida nights are nearly always fairly cold, be sure to have enough blankets.

The provision-list need not include any canned meats, as there is game in abundance in nearly all parts of Florida, and it must be a poor sportsman

W.L.C. 


\section{WILD LIFE AND THE CAMERA}

who cannot get enough for food purposes. Ducks of several varieties are to be found in immense numbers, both inland and on the coast. Shore birds, too, are abundant, while quail, doves, snipe, plover and curlew are common in suitable localities. Deer are becoming somewhat scarce, but in the more remote regions they are still to be found. Fox-squirrels, which are excellent eating, are plentiful in the cypress swamps, and may often be seen in the pine-lands. Not many years ago wild turkeys were very numerous. To see thirty or forty in a day was not at all unusual, but thanks to the pothunters they have been killed off in such numbers that it will be but a short time before they will no longer be reckoned among the game birds of Florida. The fishing throughout the State is so remarkable that to give any true account of it would be to place oneself in the awkward position of being a teller of fish stories. In the inland waters and on the coast, fishing of many kinds can be had, and the table may be supplied with scarcely any effort. On the west coast oysters are to be had for the gathering. At low tide beds of them may be found scarcely a foot below the surface, while the small "coon oysters" are high and dry. Another article of food furnished by the country is the "cabbage" 1 from the cabbage palmetto. Taking it means killing the tree, but in the wilds, where they are common, that does not matter very much. These cabbages, if young, are palatable

1 The palmetto cabbage is the core of budding leaves which is cut ont of the top of the tree. The outer leaves are peeled off and the inner ones are boiled as cabbage. 
and scarcely more difficult to digest than our own garden cabbage.

To those who have never been in Florida a few words descriptive of the conditions to be met with may not be out of place. 'The country is divided into hummocks, prairies, open swamps, cypress swamps, live oak woods, palmetto " islands," and the endless and somewhat uninteresting wastes of stunted pine-lands. Hummocks are thicklywooded places where the soil is rich, but, owing to the usual dense tangle of briars and scrub, they are more or less inaccessible. In these the shooting is good if you can get at it. Bears, wild-cats and other animals hide in these jungles, knowing full well that they will be safe from the attacks of men. A Florida prairie is a restricted low, sandy flat with a thin and irregular scattering of poor grasses. Here and there are small shallow pools around which birds flock in great numbers. Deer, wild pigs (descendants of the domestic pig), as well as coons and other "varmints," frequent these prairies. They are the feeding-places for the stately whopping crane, and sometimes turkey may be seen along the edges. The open swamps, which form a considerable part of the country, especially of the southern half, are full of water-fowl of many kinds, but it is in the cypress swamp that the finest shooting is to be had. 'These cypress swamps are scattered throughout the country, being very abundant in some localities. Each of the smaller ones is a pond, frequently seven or eight feet in depth, surrounded by a belt of cypress trees and a scant growth of myrtle and other bushes. On the outer edge of the belt, maple 


\section{WILD LIFE AND THE CAMERA}

trees are interspersed with the cypress; outside of the tree belt is a flat strip of land, sometimes with, but more often without, any grass or other vegetation. 'This strip may be anywhere from fifty to three or four hundred feet wide, and is usually bordered by palmettos and pine-land. Some of the cypress swamps are of immense size, and, I believe, are over forty miles in length. In these swamps nearly every kind of animal and bird incidental to Florida may be found, and the opportunities for both shooting and photographing are most excellent. Usually palmetto "islands" exist in the neighbourhood of cypress swamps. These "islands" are slightly above the level of the surrounding country, and are therefore dry and well adapted for camping sites. The cabbage palmetto affords shade, the dry leaves are good kindling, while the green leaves are used for the bed. The live oak country has little to recommend it except that it offers the most beautiful of camping sites, and bedding in abundance, as the trees are usually festooned with immense quantities of Spanish moss. The wood of the live oak is not suitable for a camp fire, as its smoke inflames the eyes to a painful degree. Of all the dreary things there is nothing in nature more dreary than Florida pine-land, after the novelty of it has worn off; dead level for the most part, with scrubby pine trees thinly scattered, miserable, low, stunted scrub palmetto, with wirelike grass still more thinly scattered. Between this wretched growth is the dry sand.

This is the Florida pine-land as seen from the train for hour after hour as one passes through the 
country, and yet we find a certain fascination in the very monotony of such scenery when we walk or ride through it, and not the least among its winter attractions are the robins and bluebirds who, like some of us, spend their winter in this balmy climate. With the choice of many and such different kinds of country for camping, a winter climate as good as can be had, fishing and shooting in abundance, almost endless opportunities for the camera hunter, boating, riding, bathing to suit everyone, it is a wonder indeed that more people do not take advantage of such opportunities, and leave the bitter cold of the north for this land where, even during the winter months, nearly every day is a day of sunshine. 



\section{IN DEX}

ABOLJACKNaGesic (Abols) carry, 266

Adder-tongue, 101

Adirondacks, the, 49

Alder, 245 ; the black, 283

Ambajeejus Falls, 258

Ambajeejus Lake, 258

Animal photography, outfit necessary for, 18-23

Arkansas, 148

Au Sable River, trout of, 200

Azalea, 101, 279

BACKGROUNDS, artificial, for bird photography, 10

Bait for Gilbert trout, 195-96 ; for yellow-tail, 206

"Ballasting," 159

Baltimore oriole, 12

Bark for "lean-to," 253

Bass fishing, 214, 230, 245

Bass fly, 219, 239

Bears, 323

Beaver swamps, 245

Bird and animal photography compared, 16-18

Birds and the camera, 9, 63-72; effect of heat on, 69 ; young, habits of, 71 ; responsibilities of parentage, 78-9, 120-21 ; blood-letting for, 87

Bitter-sweet, 282

Black flies, 54, 58, 243

Blinds, for caribou, 27-28; for wild duck, 147

Blood-letting for birds, 87

Blood root, 76, 101
Bluebirds, 211, 235 ; story of "Bluey," 75-90; habits, 88-89

Blue jays, 104, 283

Blue swans, 161

Boats, folding, 197

Boston, 252

Brown thrasher, 9

Bustard, 151

Buzzard, turkey, 319

CABBAGE palmetto, 322-24

Cabin, trapper's, 300

Caddis fly, larvæ, 196

California, fishing in the high Sierras, 177-200; fishing off Catalina Island, 203-7

Camera, the, size for bird photography, 10-11; kind to use for animal photography, 18 ; the reflex, 21 ; portable cases, 22-23; birds and the, 63-72; sporting possibilities, 147; in the camper's outfit, 312-13

Camping out, 252-53; winter, 307-13 ; summer, 313-18; winter camping in Florida, $318-25$

Canada jays, 30, 34, 44, 262

Canada, trapping in, 298-303

Cardinal, the, 12

Caribou, migration in New. foundland, 27-45, 244-45 ; colour, 39-40; cause of the migration, 40 ; the leads, 40-41; effect of captivity on, $42-43$

Cases, travelling, 22-23

Casting for yellow-tail, 205 
Cat, 72 ; house cat, 289 ; wild cat, 323

Catalina Island, fishing off, 203-7

Catbirds, 9, 104

Caterpillars, 106

Cat-tails, 278-79

Cedar, 259-60

Chat, yellow-breasted, 104

Chickadee, the, 93-111, 257, 270,282

Chipmunk, 276, 288, 291

Clothing outfit for winter camping, 309

Codroy River, 232

Colorado, fishing in, 197, 199

Columbia, fishing in, 200

Conifers, 180, 279

Coon, 288, 323

" Coon oysters," 322

Cotton-tail, 277, 280-82, 29091

Cow-bird, eggs of the, 130-31; the vireo and, 131-35

Crane, whopping, 323

Creels, 198-99

Crested fly-catcher, 64-69

Crow, 152

Cuckoo, European, 130

Curlew, 322

Currituck Sound, whistling swan of, 157-63

Cypress swamps, 323-24

DEcoxs for wild duck, 148,150

Deer, 151, 259-60, 267, 322, 323

Dog tracks, 289

Dogs, a trapper's, 300

Dories, 241

Dove, 322

Drake, mallard, 150

Duck, wild, blinds for, 147; decoy for, 148, 150; the photograph, 150; habits, 161 ; ducks in Florida, 322

"Durham ranger," 248
"Dusty miller," 231

"Dutchman's breeches," 76

EAstern brook trout, 194, 196 , 198

Eggs, the cowbird's, 130-35; the red-eyed vireo's, 134; the American woodcock's, 140-41

Elk, 43

Emerson, quoted, 287

European brown trout, 194

"FAIRT," 248

Fall River, 259

"Fiery Brown," 248

Films, preference for, 22 ; roll, 318

Firs, 180

Fishing, sea-trout, in New Brunswick, 211-22; trout, 177-200; yellow-tail, off Catalina Island, 203-7

Fishing-tackle, effect of dry climate on, 197-98

Flashlight work, 23

Fledglings, young in nest, 8-10; young birds feeding, 14 ; the red-ejed vireo, 134-35; woodcock, 141

Flies, for rainbow trout, 196 ; for sea-trout, 212,219 ; for salmon, 227, 229-30, 231-32, 248-50

Florida, yellow-tail of, 207 ; trapping in, 298; winter camping in, 318-25; conditions in, 323-25

"Fluff," 82

Fly-catchers, crested, 64-69

Fly-fishing, 198

Food for camping out, 311-12, $317,321-22$

Fox, the, 277, 280, 293 ; tracks, 289 ; a cross, 302 ; silver, 302-3

Fox-squirrel, 322 
Francis, Joe, Indian guide, 268

Fredericton, 211

GAFFs, 205, 251

Gaff-topsails, 39

Gander River, 232

Gentian, 182

Golden rod, 282

Goldfinch, 282

Goose, wild, 149-53, 245 ; habits, 151, 161-62 ; baiting, 152-53

Grand River, 232

Grasshopper, 89, 124, 195

Great Lakes, 159

Grilse, 228, 231, 237

Grilse rods, 240, 247

Grosbeaks, 82

Grouse, 266, 268

Grouse, ruffed, 262, 277, 282, 290

Gulls, 206

Gum trees, 167-68

H ACKLES, 196

Hare, tracks, 292

Harry's River, 232

Hawk, the, 140, 151, 280

Headgear for camping out, 309 , 310

Hens, 'possuras and, 167-73

Hepatica, 76, 101

High Sierras, fishing in the, 177-200

Holder, Mr. Charles P., 206

Hooks for yellow-tail, 206 ; double and single, 250

Horse fly, 67

Hummocks, 323

INCH-WORM, 106

Indigo bird, photographing the, 14-15; habits, 15-16

Individuality of birds, 10

Instantaneous photo work, 105

Isochromatic plates, 141-42
$\mathrm{J}_{\mathrm{A} X}$, the Canada, 30, 34, 44, 262 ; blue, 104, 283

"Jock Scott," 229, 230, 231, 248

Joe, trapper, 300-303

John, guide, 211-19

Junco, the, 282

Juniper, 183

Katahdin Brook, 263, 266, 270

Katahdin, Mount, 257-71

Katepskonegan rapids, 265

Kern River, fishing in the, 177 , 184-95

Kissimee River, 319

Klamath River, 193

LAUREL, 279

Leaders, necessity for good, 250

Leads, caribou, 40-41

Lenses, telephoto, 19-21

Licence, rod, 246 note

Long Island, Montauk Point, 150-51; swans, 157

Lupin, 180, 182

Lynx, trap for, 299

Maine, 253, 262

Mallard drake, 150

Mariposa lily, 180

Marten, trap for, 299

MeCloud River, 199

"McGinty," 220-22

Mice, 279, 280, 289, 290, 302 ; habits, 293

Michigan, 200

Mink, 277, 280-82, 288; tracks, 291-93; traps for, 299, 301 ; skins, 303

Missouri, trout, 200

Moceasin, 319

Moccasins, 309

"Mockingbird food," 87

Montauk Point, wild geese of, 150-51 
Moose, 221, 261 ; a cow-moose, 262-63

Moosebirds, 262

Morcross, 257, 271

Mosquitoes, 54, 241, 243, 316, 319

Mountain ponies, 179, 181, 183

Mules, 181, 197

Muskalunge, 245

Musk-rat, 168, 288 ; trap for, 299-300 ; skin, 302

"NEST containing eggs," 8

Nest, the red-eyed vireo's, 69-70, 131-32; the ovenbird's, 71-72; the chickadee's, 99; the worm-eating warbler's, 117-18; the American woodcock's, 139 -43 ; the whistling swan's, 159-60

Netting for salmon, 227, 232-33

New Brunswick, sea-trout of, 211-22

Newfoundland, the caribou migration, 27-45 ; fishing season in, 225-33, 247-48; to get at, 251-52; camping out in, 253

New York, 66, 90, 141, 288

Niagara Falls, 159

Nissuee, 199

North Sydney, 226

"No-see-ems," 58

O'CONNOR, DENNIS, story of "possums, 170-73

Opossum, the, hair of, in chickadee's nests, 99 and note; habits, 167, 288; a story of two 'possums, 16773

Oregon, 185 ; trout, 200

" O'Shaughnessy" hook, 206

Otter, value of skin, 288, 302 ; trap for, 300

Oven bird, the, 71-72
Owl, 277, 280; habits, 167

Oyster, 322

PAck baskets, 310

Palmetto, 321

Palmetto "islands," 324

Paper hornet, nest of, 70

Partridge berry, 262

Passaic River, 168

Passamagamet carry, 263, 265

Passamagamet Lake, 259

"Patridge," 262

Penobscot River, 258

Pig, wild, 323

Pine-land, Florida, 324-25

Pintail, 149

Pitcher plant, 261

Placentia River, 232

Plate-holders, 21-22

Plates, isochromatic, 141-42

Plover, 322

Pockwockomus carry, 265

Porcupine, the Canadian, 49 ; story of a porcupine hunt, 49-60; habits, 50-51, 293

Port-aux-Basques, 226

Prairie in Florida, 323

Pummadumcook Lake, 257 , 258, 271

Pump gun, 162

QUAIL, 277, 322

RABBiTs, 221-22, 288-90, 292

Rapids, poling through the, 263-66

Rattlesnakes, 319

Red-eyed vireo, 69-71, 101, 104

Redwood, 180; giant forests, 192-93

Reels, for trout fishing, 198 ; for salmon fishing, 250-51

Reflex camera, 21

Restigouche River, 246

Rhododendron, 279

Rifle shooting, 161

Robins, 270, 325 
Robinson's River, 232

Rods, care of, 197-98; grilse, 228,247 ; two-handed, 247

Roosevelt, Mr. Theodore, 193

"Royal coachman," 239, 249

ST. JOACHIM, 181

St. John, 252

Salinonier River, 232

Salmon, the Atlantic, 194; catching a first, 225-30; habits, 231, 248

Salmon fishing, outfit for, 23032 ; flies for, 248-50; best time for, $25 \mathrm{I}$

San Diego County, 193

San Louis Bay, 193

Sand flats of Florida, 320

Sandy River, 39, 41

Scarlet painted-cup, 182

Sea trout in New Brunswick, 211-22

Sequoia, 180

Shasta, Mount, 199

"She," 82

Shrew, tracks, 290

Sierra Nevadas, 199

"Silver doctor," 212, 214, 227, $230,231,248$

Sleeping outfit for camping, 308-9

Smudges, 316

Snakes, 318-19

Snipe, 322

Snowbird, 262

Snowshoes, 308-10

South Orange, N.J., 99 note

Spanish moss, 321, 324

Sparrows, 270

Spruce, 180

Squirrel, the red, 262, 266, 270, $276,280,288,290,291$; the grey, 276, 290; the white, 290 ; tracks, 291-92

Stalking of wild geese, 151-52 ; of swans, 161

Sunflowers, 182
Swan, the whistling, arrival at Currituck Sound, 157-58 ; speed, 158-59; habits, 15961 ; the whistler and trum. peter compared, 160-61; protection of the, 161-63; the blue swan, 161

Syringa, 180

Tanagers, 104

Telephoto work, 153; lenses for, 19-21

Tents for winter camping, 310 11 ; for summer camping, $314-15$

Trapping, 288; life of a trapper, 297-303

Traps, kinds of, 299-300

Trolling in yellow-tail fishing, 205

Trout, Kern River, 177; Gilbert, 177, 194; golden, 177, 184, 189-93 ; rainbow, 18589, 193, 195, 199; Eastern brook, 194, 196, 198 ; European brown, 194; various species, 199-200; sea-trout of New Brunswick, 211-22 ; habits, 230, 231 ; trout and salmon fishing compared, 242 ; as food, $316-17$

Trumpeter swan, 160-61

Turkey, wild, 322,323

VIRe0, red-eyed, 69-71, 101, 104 ; and the cow-bird, 129 35

Virginia deer, the, 39

Visalia, 179

Volcano Creek, 177, 184, 190

WADERS, 199, 253-54

Warbler, 104; worm-eating, $64,115-25$

Washington, 200

Water in Florida, 319-20

Weasel, 293, 302 
Western Oregon, brook trout of, 199-200

Whisky jacks, 262

White lilac, 180

Whitney, Mount, 190

Wild birds photographed, 5-16

"Wilkinsons," 212

Winthrop, quoted, 263

Woodchuek, 288

Woodcock, American, breeding habits, 139-43
Woodpecker, 70, 116, 257

Wood-thrush, 9, 11-14, 70, 104, 133

Worm-eating warbler, 64, 11525

"Yellow Sally," 238, 239, 249

Yellow-tail fishing, 203-5 ; outfit for, 206-7 


$$
+
$$ 
